\title{
Effects of Slope Geometry Alterations on Rockfall Mitigation along Highway Rock Cut Slopes in West Virginia
}

\author{
Matthew D. Idleman
}

Follow this and additional works at: https://researchrepository.wvu.edu/etd

\section{Recommended Citation}

Idleman, Matthew D., "Effects of Slope Geometry Alterations on Rockfall Mitigation along Highway Rock Cut Slopes in West Virginia" (2014). Graduate Theses, Dissertations, and Problem Reports. 5853. https://researchrepository.wvu.edu/etd/5853

This Thesis is protected by copyright and/or related rights. It has been brought to you by the The Research Repository @ WVU with permission from the rights-holder(s). You are free to use this Thesis in any way that is permitted by the copyright and related rights legislation that applies to your use. For other uses you must obtain permission from the rights-holder(s) directly, unless additional rights are indicated by a Creative Commons license in the record and/ or on the work itself. This Thesis has been accepted for inclusion in WVU Graduate Theses, Dissertations, and Problem Reports collection by an authorized administrator of The Research Repository @ WVU. For more information, please contact researchrepository@mail.wvu.edu. 


\title{
Effects of Slope Geometry Alterations on Rockfall Mitigation along Highway Rock Cut Slopes in West Virginia
}

\author{
Matthew D. Idleman, EIT \\ Thesis submitted to the \\ Benjamin M. Statler College of Engineering and Mineral Resources \\ at West Virginia University \\ in partial fulfillment of the requirements \\ for the degree of \\ Master of Science \\ in \\ Civil and Environmental Engineering \\ John D. Quaranta, Ph.D., P.E., Chair \\ Hema Siriwardane, Ph.D., P.E. \\ John Zaniewski, Ph.D \\ Department of Civil and Environmental Engineering
}

Morgantown, West Virginia

2014

KEYWORDS: Rock cut slopes, benching, planar, slope degradation, rockfall, highway safety 


\section{ABSTRACT \\ Effects of Slope Geometry Alterations on Rockfall Mitigation along Highway Rock Cut Slopes in West Virginia \\ Matthew D. Idleman}

This report presents the findings of an analysis of current highway rock cut slope design practices in West Virginia, in terms of rockfall mitigation, using the rockfall simulation computer software Colorado Rockfall Simulation Program Version 4.0. Additionally, this report presents the results of two case studies, conducted on highway rock cut slopes constructed in West Virginia, to determine the feasibility of reducing the number of geotechnical benches currently used in cut slope design while still safely retaining rockfall and remaining structurally stable.

Two case studies were conducted on as-built rock cut slopes in West Virginia. The objective of the case studies was to determine if any amount of geotechnical benches could be removed from the current design and construction practices put forth by the WVDOT in an effort to reduce excavation and maintenance costs while maintaining structural stability and adequate rockfall retention. In addition to CRSP, a numerical modeling software (SoilVision SVSlope ${ }^{\circledR}$ ) was used to determine the overall Factor of Safety of the slope section.

The first case study slope consisted mostly of hard, competent bedrock (limestone and sandstone), and initially had five benches. After modeling, it was found to have a slope stability Factor of Safety of 3.63, and an on-slope rockfall retention of 75\%. After three bench reduction trials, the final slope had one bench, a slope stability Factor of Safety of 1.47 and an on-slope rockfall retention of $88 \%$. The reduction in excavation for this slope section after removing four benches was $3670 \mathrm{ft}^{2}$ per foot of slope length. The second case study slope was composed of interbedded layers of softer, more friable bedrock (siltstone and coal) and hard bedrock (limestone). The initial as-built slope had 6 benches, and was found to have a slope stability Factor of Safety of 1.26 and an on-slope rockfall retention of $92 \%$. After four bench reduction trials, the final slope had two benches, a slope stability Factor of Safety of 1.48 and an on-slope rockfall retention of $88 \%$. The reduction in excavation for this slope section after removing four benches was $4600 \mathrm{ft}^{2}$ per foot of slope length. The results of the case study analyses showed that, with adequate bench widths and rockfall catchment ditches, backslope heights can be increased from the WVDOT-recommended 50 to 60 feet high to heights over 100 feet, while still retaining a safe amount of rockfall. 


\section{ACKNOWLEDGEMENTS}

I would like to thank Dr. John Quaranta for being a great professor, advisor, mentor, and friend. It was Dr. Quaranta who convinced me to pursue a Master's Degree, and he was an outstanding guide throughout this entire research process. He has not only helped me achieve my degree, but has also helped me be prepared for life after college. I would also like to thank Dr. Hema Siriwardane and Dr. John Zaniewski, not only for being members of my advisory committee, but for also being great professors from which I accredit much of my acquired knowledge.

I would also like to thank my colleagues-Mr. Justin Pentz, Mr. Michael Kulbacki, and Mr. Harold Russell — for helping me with this research and for being great friends throughout the years.

Additionally, I would like to thank the engineers and other great staff at the West Virginia Department of Transportation for all their assistance with this research.

Lastly, I would like to dedicate this thesis to my parents David and Rhonda Idleman, and my loving fiancé Mary Catherine Hamilton. These three individuals have given me more love and support throughout my academic career than I will ever be able to repay them for, and I am truly grateful.

"I can do all things through Christ, who strengthens me." - Philippians 4:13 


\section{EXECUTIVE SUMMARY}

With an advancing highway system in the mountainous state of West Virginia, there will continue to be an increasing number of large rock cuts along highways in the state. These rock cut slopes often come with a rockfall hazard, especially if the slope is improperly designed, constructed, or lacking in proper mitigation techniques. For this research, current WVDOT practices for designing highway rock cut slopes were researched and tested using rockfall simulation software to determine if they were statistically safe from rockfall. In addition, a study was conducted to determine the feasibility of an alternative design method from current WVDOT guidelines for rock cut slopes that involves a reduction in geotechnical benches with the objective of an increase in cost efficiency compared to current practices.

This research was performed under contract with the West Virginia Department of Transportation, Division of Highways; Research Project 283 "Probability Analysis \& Design Approach for Continuous Slope Use in West Virginia" (WVDOH RP-283).

Research Objectives

The objectives of this research are as follows:

1. To conduct a literature review on both West Virginia DOT and other transportation agencies in states with similar topography and geology to West Virginia to determine if WVDOT's current practices are comprehensive.

2. To develop a cut slope rockfall hazard rating system to aid in the organization and management of new rock cut slopes; use the new hazard rating system to assess cut slope sites with the highest rockfall hazard, and use that information to help determine what characteristics of a cut slope create the highest hazard.

3. To calibrate Colorado Rockfall Simulation Program Version 4.0 for West Virginia topography and geology.

4. To use Colorado Rockfall Simulation Program Version 4.0 to analyze the effectiveness of WVDOT's current cut slope design practices in terms of rockfall safety.

5. To use observations and analysis of newly constructed highway rock cut slopes, along with Colorado Rockfall Simulation Program Version 4.0, to determine the feasibility of reducing the number of geotechnical benches used in the design of rock cut slopes while maintaining or improving the stability and safety.

\section{Literature Review}

The initial literature investigation was conducted solely on WVDOT's Design Direction 403 (WV DD-403), which are the transportation agency's current design guidelines for addressing highway rock cut slopes. WV DD-403 provides specific recommendations for designing with four of the most common bedrock types found within cuts in West Virginia. Design suggestions are made for backslope angles, backslope heights, bench widths, distance between benches, and lower (catchment) bench implementation. The development of the numerical recommendations made in WV DD-403 are not thoroughly explained or defended with examples, and, as mentioned, one of the objectives of this research was conducted to either confirm or adjust the recommendations put forward by WVDOT.

The comparative literature review to WV DD-403 was conducted on the following state transportation agencies: Pennsylvania, Ohio, Montana, Colorado, and Oregon. While West 
Virginia DOT's guidelines for the design of rock cut slopes are considerably thorough, the implementation of certain guidelines used by other state transportation agencies may create a more comprehensive, and thus safer, guideline document. For instance, WVDOT recommends the testing of rock samples for compressive strength and slake durability, while Pennsylvania and Ohio DOTs recommends a more thorough investigation with testing for shear strength, Rock Quality Designation (RQD), point load testing, and sulfur testing. Montana DOT recommends that the minimum allowable Factor of Safety of 1.50 for the structural stability of a rock cut slope, while WVDOT only recommends a minimum Factor of Safety of 1.25. Oregon DOT recommends the implementation of a Rockfall Hazard Rating System (RHRS) to develop a database of rated rock cut slopes and aid in the allocation of resources to those slopes in the database that are the most hazardous and in the greatest need of remediation. This rating system (RHRS) is used by all the other state transportation agencies that were researched, except for West Virginia. Additionally, Oregon DOT has set a statistical limit on the percentage of falling rocks from a cut slope that they will allow to reach the roadway at $10 \%$, or a minimum required rockfall retention of 90\%. WVDOT's DD-403 does not address this issue, and thus there is no known threshold for the state. Lastly, WVDOT recommends implementing a bench 5 feet above the toe of slope for rockfall catchment purposes, but Oregon DOT recommends implementing a catchment ditch at the toe of all rock cut slopes for better mitigation of rockfall. The aforementioned guidelines listed from other state transportation agencies are recommended to be implemented by WVDOT for addition into the rock cut slope design directives for West Virginia.

\section{Rockfall Hazard Rating System}

The first documented organizational system for highway rock cut slopes, Rockfall Hazard Rating System (RHRS), was originally developed as a means of properly allocating resources to the slopes in greatest need of remediation due to rockfall-related hazards. The idea of using a modified version of RHRS for the advancement of safe design of new rock cut slopes did not come about until 2013, and is still in development. This research built on the idea by using a modified version of the original system to rate newly constructed rock cut slopes, and compile a database to determine what characteristics of cut slopes in West Virginia are creating the highest rockfall-related hazards. These hazardous slopes were then able to be further tested with computer modeling to develop new guidelines for an overall increase in safety from rockfallrelated incidents on rock cut slopes.

The categories for this newly modified version of RHRS were developed based on recommendations from an Federal Highway Administration-funded report on using RHRS for new slopes (Anderson, 2013), along with field observations during this research. In comparison to the original RHRS rating system developed by ODOT, the modifications included adjustments in rating criteria to account for higher overall slope height, adding a rating category for distance from toe of slope to paved shoulder, changing the wording for the geologic character cases to aid in better comprehension, and adding rating categories for large root vegetation and maintenance frequency. These modifications created seven categories relating to probability of failure and seven categories relating to consequences of failure. This allowed for an even assessment of the overall rockfall hazard. Additionally, a new procedure was developed to help RHRS rating technicians when using the system on new cut slopes. Lastly, recommendations were made to use GIS software in the creation of the RHRS database, such as ArcGIS. A classification algorithm (Jenks) within ArcGIS allowed for easy identification of the most hazardous slopes. 
Preliminary testing was conducted during the research project, using the modified version of RHRS for new cut slopes. While only a limited number of slope sites were rated (six total), the rating procedure and overall system appeared to work properly and produce quality results. The slope site that was visually observed to be the most hazardous received the highest total RHRS score (444), and was much higher than the next highest slope site score (384). The remaining scores, from slope sites appearing more visibly competent and safe, ranged from 354 to 198. More testing is needed on this new RHRS system to determine its overall accuracy and feasibility.

\section{Colorado Rockfall Simulation Program Analysis}

The two-dimensional version of Colorado Rockfall Simulation Program (Version 4.0) was selected for this research, due to the limitations of the three-dimensional version's large resolution that made the geometric precision necessary to properly model these cut slopes nearly impossible. The simulations of the two-dimensional version of CRSP (CRSP-2D) relied on three parameters: normal coefficient of the falling rock, tangential coefficient of the falling rock, and surface roughness of the slope face. While surface roughness is an easily estimated value based on visual observations, the normal and tangential coefficients must be selected based on given ranges for the rock type in consideration. The provided value ranges for these parameters in the software manual were very broad, thus it was deemed necessary to calibrate CRSP-2D using field measurements prior to using the software in the bench reduction study.

For West Virginia, the calibration process was developed on the assumption that, in respect to rock hardness, the geology of West Virginia consists of primarily of two distinct types of bedrock: soft bedrock (coal, shale, siltstone) and hard bedrock (sandstone, limestone). A detailed field calibration method was developed to pinpoint normal and tangential coefficient values for both hard bedrock and soft bedrock. The process consisted of finding slope sites with both large rock fall events and a stratification that allowed for approximate determination of every falling rock's release zone. One of the selected test sites needed to consist predominately of soft bedrock, and the other predominately of hard bedrock. Each of the falling rocks at these sites were counted, measured, and assigned the appropriate bedrock type. Additionally, the geometry of the slopes were measured and recorded. The slope sections were then modeled in CRSP-2D, and the normal and tangential coefficients for each bedrock type were altered until the simulation results matched the field observations from these test sites.

After calibration, CRSP-2D was used to assess the current WVDOT cut slope design guidelines in terms of rockfall safety and mitigation. Using design tables from WV DD-403, generalized profiles were developed for both soft and hard bedrock slopes. Depending on the bedrock type, three different backslope angles were modeled, along with three different bench widths (15 ft., $25 \mathrm{ft}$., $35 \mathrm{ft}$.) and three different backslope heights (50 ft., $60 \mathrm{ft} ., 70 \mathrm{ft}$.) between benches. All other factors were kept constant, including the number of benches (3), rockfall shape and density, the rockfall release zone, and CRSP-2D hardness and roughness parameters. The results that were recorded included the percentage of rockfall retained on each bench and at the toe, the average rockfall runout past the toe, and the average velocity, kinetic energy, and bounce height at the toe of slope. A total of 108 models were simulated in this analysis of WV DD-403 guidelines.

The results of the WVDOT design guide analysis also determined the slope characteristics that had the strongest effect on rockfall behavior, thus the study doubled as a sensitivity analysis. 
According to the data, the change in slope height had the weakest effect on rockfall retention and runout results, while small changes in both bench width and backslope angle were very sensitive to the results. It was found that $15 \mathrm{ft}$. wide benches, regardless of the bedrock type and backslope angles, were inadequate at retaining a safe amount of rockfall from the roadway. Additionally, the shallower backslope ratios $(1 / 2 \mathrm{H}: 1 \mathrm{~V}$ and less) provided more contact area for the falling rocks, which also caused inadequacy at retaining a safe amount of rockfall on the slope, unless bench widths were at least 25 feet. These shallower backslope ratios also caused the highest average runout past the toe of slope.

The slope profiles developed for the parametric analysis were then altered to remove the lowest of the three benches and implement the aforementioned Rockfall Catchment Area Design, or RCAD-style ditch at the toe of slope. The ditch was designed to have the same width as a $25 \mathrm{ft}$. bench, and a depth below roadway grade of 6 feet. The exiting slope of the ditch has a $4 \mathrm{H}: 1 \mathrm{~V}$ slope for vehicle recovery so the additional cost of a guiderail system is not needed. The results from simulations for these slope profiles were compared to the results from the original slope profiles designed to WV DD-403 recommendations, and the results showed a substantial increase in rockfall retention when the ditch was used. On average, the ditch retained $60 \%$ more rocks than the bottom catchment bench did. Also, the ditch significantly reduced the average bounce height and kinetic energy of rocks reaching the toe of slopes with shorter than $70 \mathrm{ft}$. high backslopes.

\section{Colorado Rockfall Simulation Program Outcomes}

After the results from the parametric analysis were analyzed, recommendations were made to adjust the design guidelines in WV DD-403. The recommended adjustments to WV DD-403 design guidelines are as follows:

- For Type 1 Bedrock slopes (predominantly hard bedrock):

- A minimum bench width of 25 feet should be used.

- Backslope ratios should be as steep as structurally possible to reduce rockfall runout, with a minimum ratio of $1 / 4 \mathrm{H}: 1 \mathrm{~V}$ if no ditch is being used, and $1 / 2 \mathrm{H}: 1 \mathrm{~V}$ if a ditch is being used.

- For Type 3 Bedrock slopes (predominantly soft bedrock):

- A minimum bench width of 30 feet should be used.

- Backslope ratios, where structurally possible, should be no shallower than $3 / 4 \mathrm{H}: 1 \mathrm{~V}$, with or without a ditch at the toe of slope.

- For both Bedrock types:

$\circ$ Backslope heights should be the maximum allowable height for safe blasting and construction, as they have minimal effect on rockfall safety.

- It is recommended that all rock cut slopes with potential rockfall-related problems implement an RCAD-style ditch system at the toe of slope. The increase in extra excavation by implementing the ditch is negligible in the overall excavation of the cut slope section.

V. Bench Reduction Analysis

For this research, two case studies were conducted to determine if the findings from the parametric analysis could be used to design rock cut slopes with fewer geotechnical benches 
compared to current WVDOT guidelines while maintaining structural stability and roadway user safety. Current WVDOT guidelines recommend that space between benches do not extend past 2.5 times the bench width, which can create a large amount of volume to excavate with taller slopes. An overall reduction in benches, while not necessary, would provide easier maintenance and potentially substantially reduce excavation costs.

For the case studies, two newly constructed highway rock cut slopes in West Virginia were selected, one classifying as a Type 1 Bedrock slope and one classifying as a Type 3 Bedrock slope under WV DD-403 criteria. The selected Type 1 Bedrock slope site was a section of US Route 48 in Hardy County. The selected Type 3 Bedrock slope site was a section of US Route 121 in Raleigh County. While the focus of the case studies was modeling with CRSP-2D to determine rockfall safety, slope stability was also modeled using SoilVision SVSlope ${ }^{\circledR}$, a finite element modeling program. SVSlope ${ }^{\circledR}$ was used to ensure the slope was stable and to determine areas of the slope face that were most prone to become rockfall release zones.

The given slope section was first observed and measured in the field and a geometric profile, complete with borehole log measurements, was created with the aid of construction plans. The as-built slope section was then modeled in SVSlope ${ }^{\circledR}$, and the lowest Factor of Safety was recorded for the overall slope section. If that met the minimum requirement of 1.25, the slope section was then modeled in CRSP-2D. The upper portion of each backslope was simulated as a potential rockfall release zone, and the release zone with the lowest percent on-slope retention was recorded. If that retained percentage was $\geq 90 \%$, the slope section was found to be both stable and safe. The next step was to observe the stratigraphy of the slope section, and determine the most feasible bench to remove. This was done by trying to satisfy these two objectives:

1. Bench where a hard bedrock layer rests on a soft bedrock layer to reduce undercutting.

2. Bench at least once every 150 feet to reduce rockfall kinetic energy and provide construction and blasting access.

Benches were removed, one at a time, from the given slope section until both objectives were reached. The remaining benches were also redesigned to be the minimum width acceptable for the given Bedrock Type, as determined in the parametric analysis conducted above. After each bench removal, the new slope profile geometry was modeled in both SVSlope ${ }^{\circledR}$ and CRSP-2D to determine the feasibility of bench reduction, in terms of structural stability and rockfall safety. In addition to the removal of benches, after the as-built slopes were modeled a catchment ditch, or RCAD-style ditch, was implemented at the toe of the given slope section in place of the lowest bench in all trials.

\section{Bench Reduction Outcomes}

The results for the Type 1 Bedrock case study slope, consisting mostly of sandstone and limestone, showed that a reduction in geotechnical benches is both feasible and potentially economical. The as-built slope section, with a total of 5 benches, had a stability Factor of Safety of 3.62 and a minimum on-slope rockfall retention of $75 \%$. With only one bench, the Type 1 Bedrock slope had a stability Factor of Safety of 2.12 and a minimum on-slope rockfall retention of $88 \%$. While the Factor of Safety did significantly reduce when benches were removed, the final Factor of Safety was still significantly over the WVDOT minimum value of 1.25. Additionally, the overall reduction in excavation area for this case study was approximately 3670 $\mathrm{ft}^{2}$ per lineal foot of roadway. 
The results for the Type 3 Bedrock case study slope, consisting mostly of interbedded layers of siltstone, sandstone, and coal, also showed that a reduction in geotechnical benches is feasible and potentially economical. The as-built slope section, with a total of 6 benches, had a stability Factor of Safety of 1.25 and a minimum on-slope rockfall retention of $92 \%$. With a new total of only 2 benches (reducing to one was unfeasible due to overall slope height), the Type 3 Bedrock slope had a stability Factor of Safety of 1.48 and a minimum on-slope rockfall retention of $88 \%$. In this case study, the predicted stability of the slope section actually improved considerably with the removal of 4 benches, while the overall rockfall retention percentages held consistent due to the addition of the catchment ditch at the toe of slope. Additionally, the overall reduction in excavation area for this case study was approximately $4600 \mathrm{ft}^{2}$ per lineal foot of roadway.

Overall, the case studies are useful examples of the conclusions made from the parametric analysis, which is that highway rock slopes in West Virginia can potentially be redesigned in a way that could save WVDOT construction and maintenance effort and cost. These slopes can be adequately stable and safe without constructing a geotechnical bench every 50 to 70 feet of backslope. Additionally, the implementation of a rockfall catchment ditch, designed to standards similar to the RCAD system, allow for a statistically safe percentage of rockfall retention from the roadway for nearly all slopes. Lastly, benches should never be less than 25 feet wide, and should be even wider for slopes consisting mostly of soft bedrock.

VII. Conclusions

In summary, the use of a rockfall rating system such as RHRS, rockfall simulation program such as CRSP-2D, and a finite element stability modeling software such as SoilVision SVSlope ${ }^{\circledR}$ allows for a safer highway system in mountainous terrain. RHRS helps to pinpoint hazardous slopes, SVSlope ${ }^{\circledR}$ determines the weakest areas of the slope where rockfall may initiate from, and CRSP-2D determines the behavior of rockfall due to the geometry and composition of the slope. 


\section{TABLE OF CONTENTS}

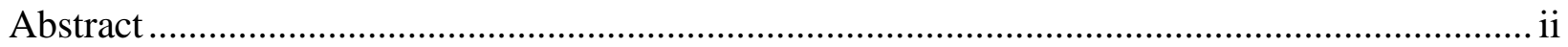

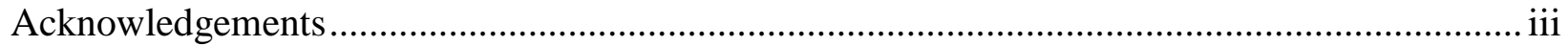

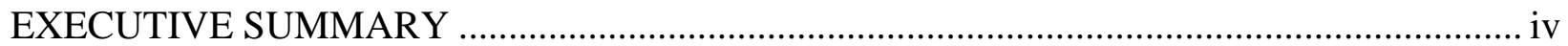

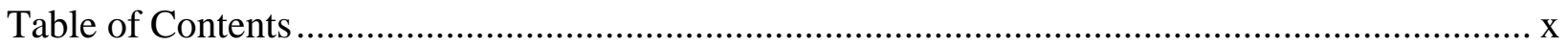

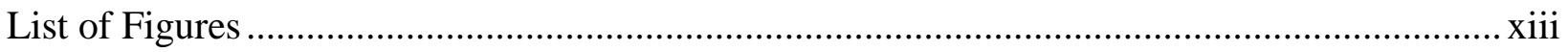

List of Tables ................................................................................................................ Xvi

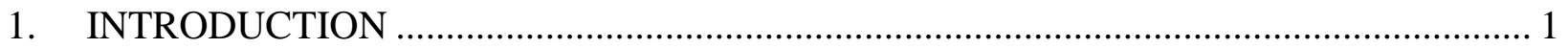

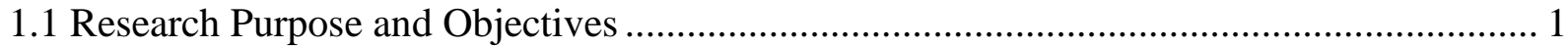

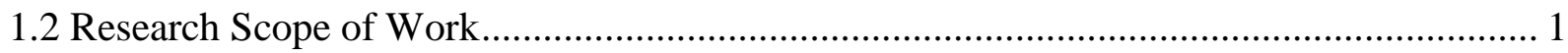

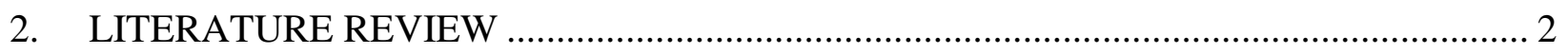

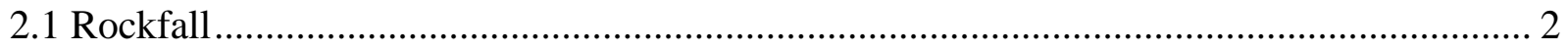

2.1.1 Rockfall Attenuation and Mitigation Methods ........................................................... 3

2.1.1.1 Rockfall Catchment Area Design (RCAD) ....................................................... 3

2.2 WVDOT Rock Cut Slope Design Guide ...................................................................... 3

2.2.1 Other State Agency Practices.......................................................................................... 4

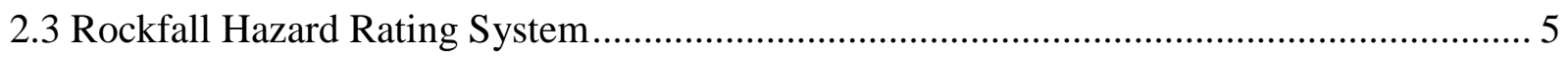

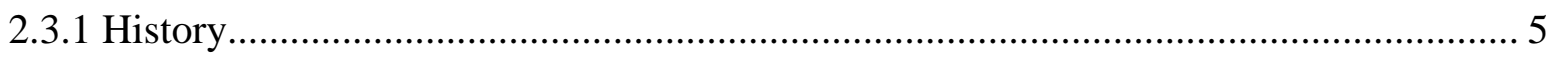

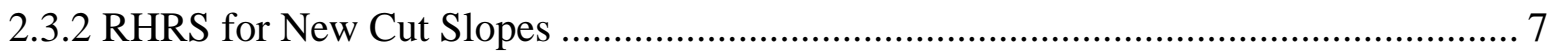

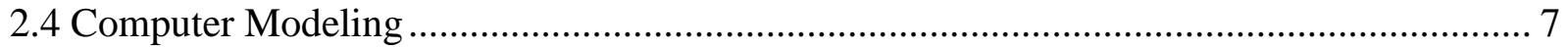

2.4.1 Colorado Rockfall Simulation Program...................................................................... 7

2.4.1.1 Features of CRSP Version 4.0 (2-Dimensional) ................................................. 8

2.4.1.2 Features of CRSP 3-Dimensional Version 1.0 ……....................................... 9

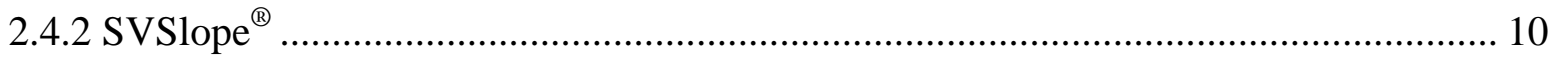

2.4.2.1 Hoek-Brown Failure Criterion ........................................................................ 10

2.4.2.2 General Limit Equilibrium Analysis Method .......................................................... 11

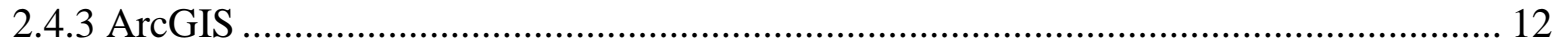

2.4.3.1 Jenks Algorithm ................................................................................... 12

3. ROCKFALL HAZARD RATING SYSTEM (RHRS) METHOD DEVELOPMENT ......... 14

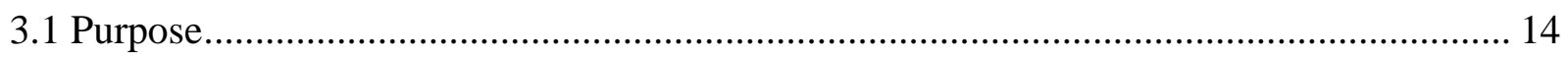

3.2 Development of System for New Slopes ................................................................... 14

3.3 RHRS Rating Category Descriptions from Table 3.1:....................................................... 15

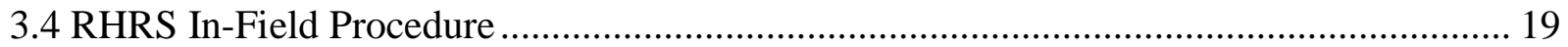




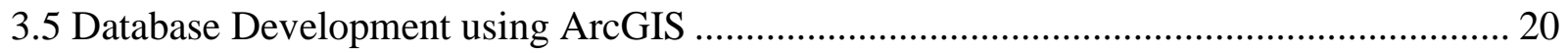

4. COLORADO ROCKFALL SIMULATION PROGRAM (CRSP) …………..................... 24

4.1 Version Selection Process....................................................................................... 24

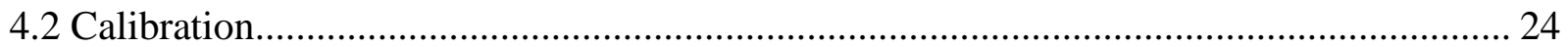

4.2.1 In-Field Calibration Technique for West Virginia..................................................... 25

4.2.1.1 "Rock Count" Calibration Method ..................................................................... 25

4.2.1.2 Alternate Field Calibration Method ................................................................... 28

4.2.2 CRSP Version 4.0 Program Calibration ................................................................ 28

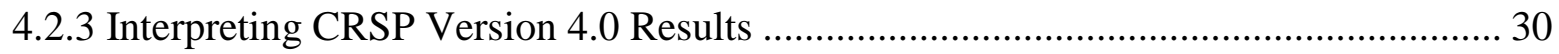

4.2.4 CRSP-2D Calibration Results for West Virginia............................................................ 33

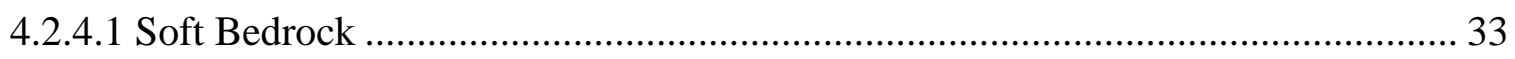

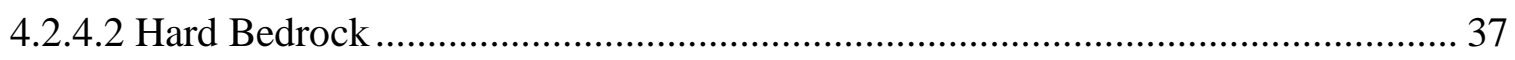

4.3 Sensitivity Analysis of WVDOT Cut Slope Design Directives using CRSP-2D ............... 41

4.3.1 WV DD-403 Type 1 Bedrock CRSP-2D Sensitivity Study Results ............................. 44

4.3.2 WV DD-403 Type 3 Bedrock CRSP-2D Sensitivity Study Results............................. 48

4.3.3 Implementation of a Catchment Ditch in CRSP-2D Sensitivity Analysis................... 52

4.3.4 Summary of Findings for CRSP-2D Sensitivity Analysis .......................................... 57

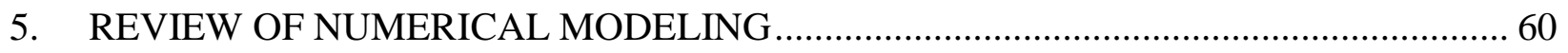

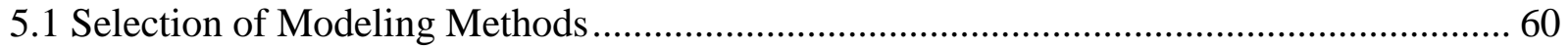

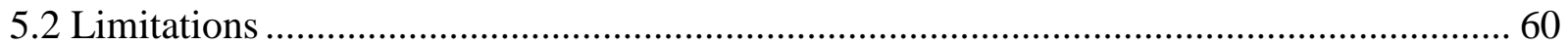

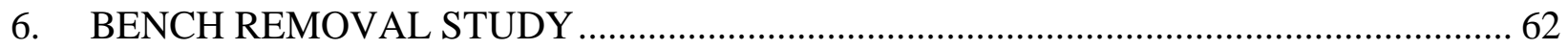

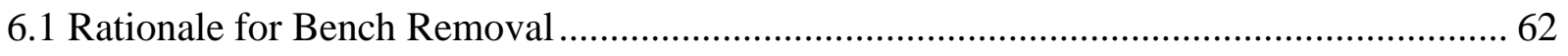

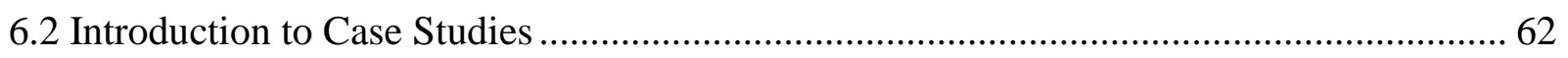

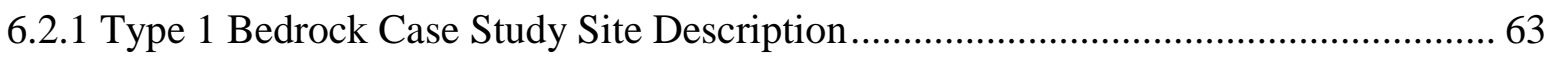

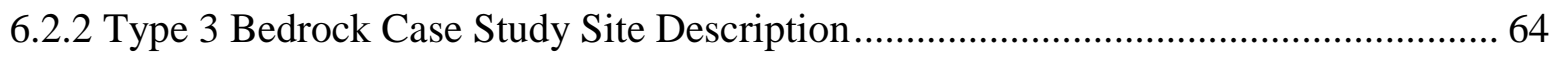

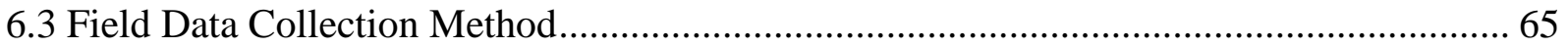

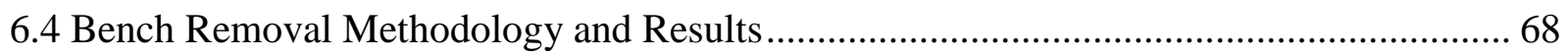

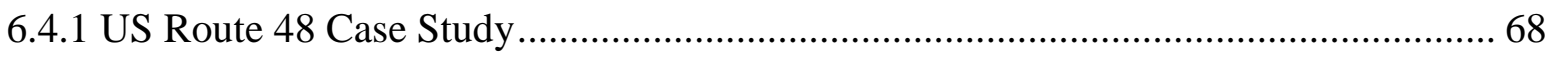

6.4.1.1 As-built Slope Feasibility Case Study .................................................................. 69

6.4.1.2 Bench Removal Feasibility Case Study Trial 1 ................................................... 74

6.4.1.3 Bench Removal Feasibility Case Study Trial 2 ................................................ 77

6.4.1.4 Bench Removal Feasibility Case Study Trial 3 .................................................... 80

6.4.1.5 US Route 48 Case Study Overall Results ......................................................... 83 


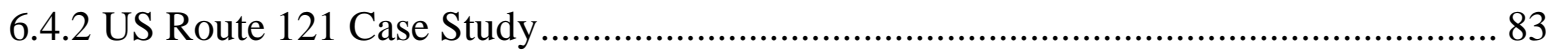

6.4.2.1 As-built Slope: Feasibility Case Study …………………………………….... 85

6.4.2.2 Bench Removal Feasibility Case Study Trial 1 ................................................. 89

6.4.2.3 Bench Removal Feasibility Case Study Trial 2 ……......................................... 92

6.4.2.4 Bench Removal Feasibility Case Study Trial 3 ................................................... 95

6.4.2.5 US Route 121 Case Study Overall Results ........................................................ 98

6.5 Excavation Reduction Examples …………………….................................................. 98

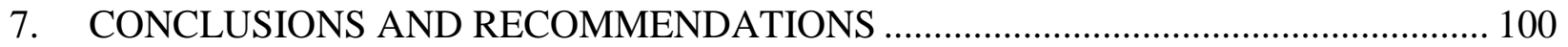

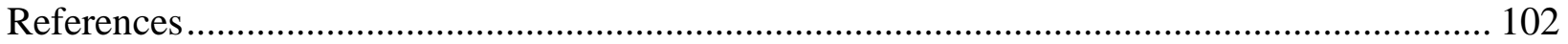

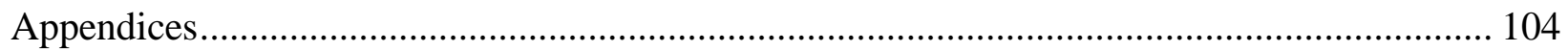

Appendix I: Original Rockfall Hazard Rating System Descriptions ..................................... 104

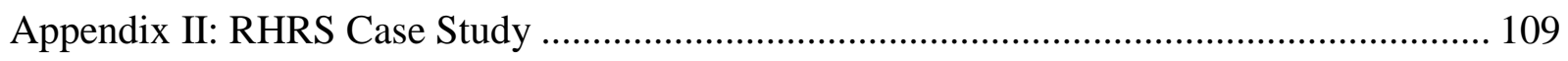

Location 1: US Route 48, Westbound Lane ……………………………………….......... 109

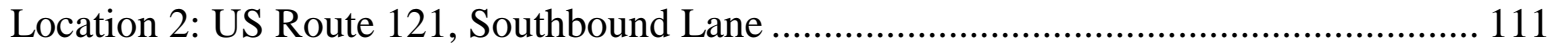

Location 3: US Route 121, Northbound Lane ................................................................ 113

Location 4: US Route 50, on-ramp for Eastbound Lane ................................................... 115

Location 5: US Route 35, Southbound Lane ………………………............................ 117

Location 6: US Route 35 exit ramp (to WV Route 817 N) .............................................. 119

Appendix III: Colorado Rockfall Simulation Program Version 4.0 Field Calibration Workbook 121

Appendix IV: Additional CRSP-2D Field Calibration Models .............................................. 133

Appendix V: CRSP-2D Simulation Screenshots for Case Studies ......................................... 139

Appendix VI: Rock Slope Design Guide Using CRSP-2D .................................................. 145 


\section{LIST OF FIGURES}

Figure 2.1 Illustration of a "topple" slope failure (left) and a "fall" slope failure (right).

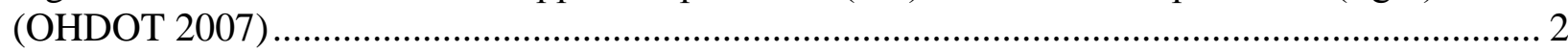

Table 2.2 Original Rockfall Hazard Rating System (Pierson, 1991)....................................... 6

Figure 3.1 Visual Representation of "strike" and "dip" in a bedding plane (Myers 2010)..... 16

Figure 3.2 Map created in ArcGIS from 4 downloaded layers: WVDOT district outlines, State

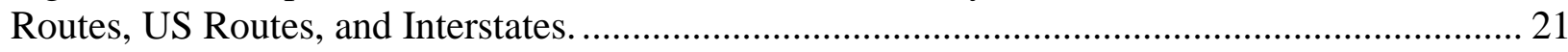

Figure 3.3 Placemarked RHRS slope sites in Google Earth. ............................................... 22

Figure 3.4 Map created in ArcGIS that displays the RHRS score ranges in a color scale and allows the user to easily detect which slope sites are the most hazardous. .................................. 23

Figure 4.1 Visual Representation of ideal slope type for calibration site ……….................... 26

Figure 4.2 CRSP 2-D Slope Profile showing simulation trial results ...................................... 31

Figure 4.3 CRSP Analysis Point Statistics ...................................................................... 32

Figure 4.4 Probability analysis for each rock at "Analysis Point 1" in a CRSP simulation trial.

Figure 4.5 Line graph output by CRSP-2D depicting the maximum velocity of the fallen rocks as they travelled down the slope profile during simulation ....................................................... 33

Figure 4.6 Soft Bedrock Calibration Site 1 Slope Profile created in CRSP-2D ....................... 35

Figure 4.7 Hard Bedrock Calibration Site 1 Slope Profile created in CRSP-2D ..................... 39

Figure 4.8 Graph depicting the ability of benches to be used as rockfall catchment on Type 1

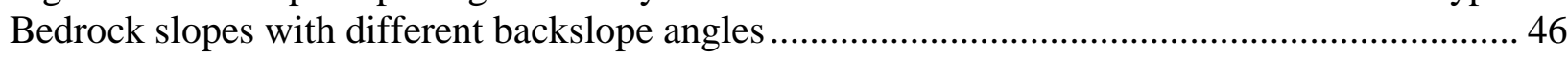

Figure 4.9 Graphs depicting the relationships between Bench Width (4.6a.) vs. Average Rockfall Runout Distance, and Backslope Angle (4.6b) vs. Average Rockfall Runout Distance for Type 1 Bedrock slopes .................................................................................................. 47

Figure 4.10 Graph depicting the ability of benches to be used as rockfall catchment on slopes with different backslope angles.

Figure 4.11 Graphs depicting the relationships between Bench Width (4.10a) vs. Average Rockfall Runout Distance, and Backslope Angle (4.10b) vs. Average Rockfall Runout Distance .

Figure 4.12 Sample RCAD Ditch Design Chart for 80-ft. slopes (ODOT 2001) ................... 53

Figure 4.13 Visual Representation of the modified RCAD ditch developed for the CRSP-2D sensitivity analysis

Figure 4.14 Graph comparing the rockfall catchment effectiveness of a WV DD-403 designed lower bench (blue) versus a RCAD designed ditch (red) ............................................ 54

Figure 4.15 CRSP-2D Simulation Results for a Type 1 Bedrock slope with $70 \mathrm{ft}$. tall backslopes, $25 \mathrm{ft}$. wide benches, and an RCAD-style ditch at toe. The red circle depicts the small percentage of rocks that launched over the ditch. 56 
Figure 4.16 Bench Width vs. Percent On-Slope Retention for a.) Hard Bedrock w/o ditch, b.) Hard Bedrock with RCAD-style ditch, c.) Soft Bedrock w/o ditch, d.) Soft Bedrock with RCADstyle ditch. 57

Figure 4.17 Rock cut slope design flow chart for use with WV DD-403 guidelines ............ 59

Figure 5.1 Example of a slip surface created with SVSlope ${ }^{\circledR}$ modeling software ................. 61

Figure 6.1 Slope Section of US Rt. 48 (Corridor H) in WVDOT District 5, Grant Co., WV . 63

Figure 6.2 Vegetative cover on bench and portions of backslope on the US Rt. 48 Cut Slope

Section

Figure 6.3 Slope Section of US Route 121 (Coalfields Expressway) in WVDOT District 10, Raleigh Co., WV.

Figure 6.4 Accumulation of large rocks on a bench on the US Rt. 121 Cut Slope Section..... 65

Figure 6.5 Two-Dimensional Profile of As-built Slope Section of US Route 48 ................. 70

Figure 6.6 Two-Dimensional Slope Section Profile and Stability Analysis results for As-built slope section on US Route 48.

Figure 6.7 Two-Dimensional Slope Section Profile from As-built slope section of US Route 48 modeled in CRSP-2D.

Figure 6.10 Two-Dimensional Slope Section Profile and Stability Analysis results for second

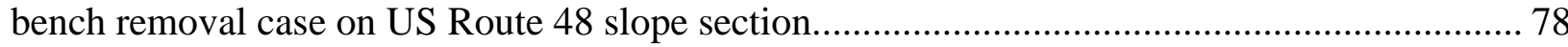

Figure 6.12 Two- Dimensional Slope Section Profile and Stability Analysis results for third bench removal case on US Route 48 slope section....................................................... 81

Figure 6.14 Two-Dimensional Profile of As-built Slope Section of US Route 121 ............. 85

Figure 6.15 Two-Dimensional Slope Section Profile and Stability Analysis results for As-

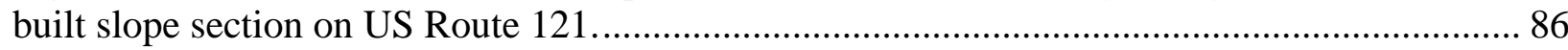

Figure 6.17 Two-Dimensional Slope Section Profile and Stability Analysis results for Bench Reduction Trial 1 slope section on US Route 121 .......................................................... 90

Figure 6.19 Two-Dimensional Slope Section Profile and Stability Analysis results for Bench Reduction Trial 2 slope section on US Route 121....................................................... 93

Figure 6.21 Two-Dimensional Slope Section Profile and Stability Analysis results for Bench

Reduction Trial 3 slope section on US Route 121........................................................... 96

Figure 6.23 Cross-Sectional display of excavation reduction associated with bench removal on case study section of US Route 48 .

Figure 6.24 Cross- Sectional display of excavation reduction associated with bench removal

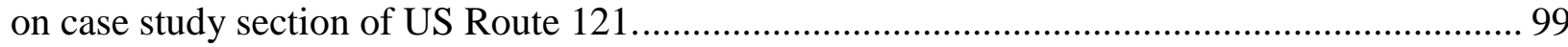

Soft Bedrock Calibration Site 2 Slope Profile created in CRSP-2D ...................................... 134

Hard Bedrock Calibration Site 2 Slope Profile created in CRSP-2D .................................... 137

As-Built Case Study Slope Section of US Route 48 - Release Zone: Top of Backslope 2 ....... 139 
Bench Removal Trial 4 for Case Study Slope Section of US Route 48 - Release Zone: Top of

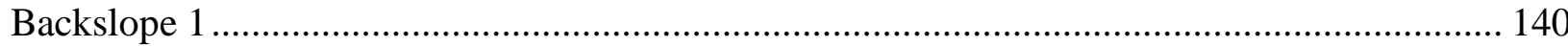

Bench Removal Trial 3 for Case Study Slope Section of US Route 121 - Release Zone: Top of

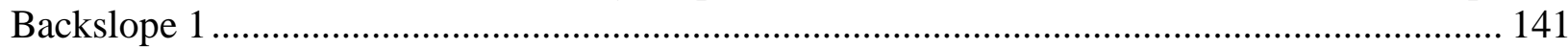

Bench Removal Trial 3 for Case Study Slope Section of US Route 121 - Release Zone: Top of

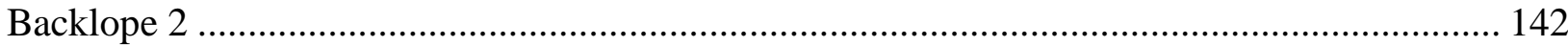

Bench Removal Trial 3 for Case Study Slope Section of US Route 121 - Release Zone: Top of

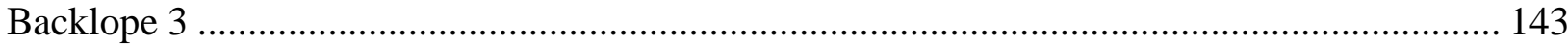

Bench Removal Trial 4 for Case Study Slope Section of US Route 121 - Release Zone: Top of

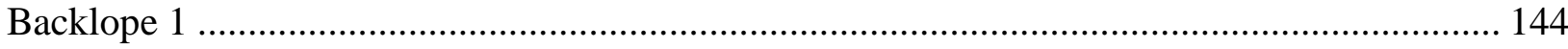




\section{LIST OF TABLES}

Table 2.1 Comparison of WVDOT Rock Cut Slope Guidelines with other State

Transportation Agencies. 5

Table 2.3 General Tangential Coefficient Ranges for Different Slope Surface Types (Jones, 2000) 8

Table 2.4 General Normal Coefficient Ranges for Different Slope Surface Types (Jones, 2000) 9

Table 3.1 Updated RHRS Rating Table for New Rock Cut Slopes....................................... 15

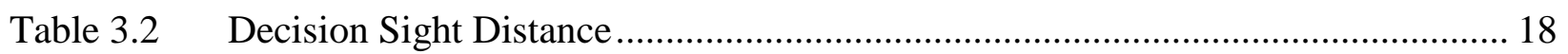

Table 4.1 CRSP-2D Parameters and Possible Ranges of Values ............................................ 24

Table 4.2 Cell Identification Table to be used with CRSP Field Calibration........................... 27

Table 4.3 Rockfall Tally Table to be used with CRSP Field Calibration ................................. 27

Table 4.4 General Information collected from Soft Bedrock CRSP-2D Calibration Site 1 ... 33

Table 4.5 Completed Cell Identification Table for Soft Bedrock Calibration Site 1............... 34

Table 4.6 Completed Rockfall Tally Table for Soft Bedrock Calibration Site 1..................... 34

Table 4.7 Trial-and-Error CRSP-2D Calibration for Soft Bedrock with Diameter of 1.25 Feet 36

Table 4.8 Trial-and-Error CRSP-2D Calibration for Soft Bedrock with Diameter of 2.30 Feet

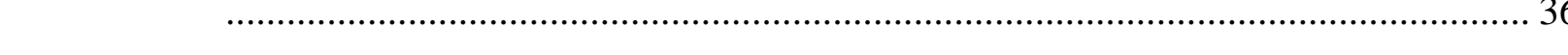

Table 4.9 Calibrated CRSP-2D Coefficient Values for Soft Bedrock in West Virginia ......... 37

Table 4.10 General Information Collected from Hard Bedrock CRSP-2D Calibration Site 1. 38

Table 4.11 Completed Cell Identification Table for Hard Bedrock Calibration Site 1 ............. 38

Table 4.12 Completed Rockfall Tally Table for Hard Bedrock Calibration Site 1 .................. 39

Table 4.14 Calibrated CRSP-2D Coefficient Values for Soft Bedrock in West Virginia ......... 41

Table 4.15 WV DD-403 Guidelines for Rock Cut Slope Design in Different Bedrock Types (WVDOH 2006).

Table 4.16 Results for CRSP Simulations involving Type 1 Bedrock and $50 \mathrm{ft}$. Backslope Heights

Table 4.17 Results for CRSP Simulations involving Type 1 Bedrock and $60 \mathrm{ft}$. Backslopes Heights

Table 4.18 Results for CRSP Simulations involving Type 1 Bedrock and $70 \mathrm{ft}$. Backslope Heights

Table 4.19 Results for CRSP Simulations involving Type 3 Bedrock and $50 \mathrm{ft}$. Backslope Heights

Table 4.20 Results for CRSP Simulations involving Type 3 Bedrock and $60 \mathrm{ft}$. Backslope Heights 
Table 4.21 Results for CRSP Simulations involving Type 3 Bedrock and $70 \mathrm{ft}$. Backslope Heights

Table 4.22 Comparisons of the change in Velocity and Kinetic Energy at the roadway edge between using a catchment bench and using an RCAD-style ditch for Type 1 Bedrock Slopes . 55 Table 4.23 Comparisons of the change in Velocity and Kinetic Energy at the roadway edge between using a catchment bench and using an RCAD-style ditch for Type 3 Bedrock Slopes . 55

Table 4.24 Supplemental table to Design Flow Chart in Figure 4.16 ...................................... 58

Table 6.1 Comparison of Construction Plan Geometry and Field Measurements of Two Case Study Sites in West Virginia. 67

Table 6.2 Geometric Information for US Route 48 Case Study Slope Section 69

Table 6.3 Selected Values for Various Parameters needed for Numerical Modeling with Hoek

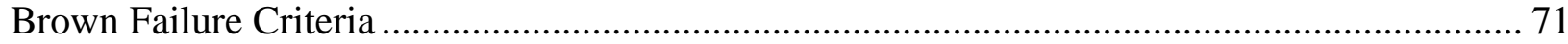

Table 6.4 CRSP-2D Simulation Runs with Various Rockfall Release Zones on As-built Case Study Slope on US Route 48 74

Table 6.5 CRSP-2D Simulation Runs with Various Rockfall Release Zones on Bench Reduction Trial 1 of US Route 48 Case Study Slope ................................................................ 77

Table 6.6 CRSP-2D Simulation Runs with Various Rockfall Release Zones on Bench Reduction Trial 2 of US Route 48 Case Study Slope 79

Table 6.7 CRSP-2D Simulation Runs with Various Rockfall Release Zones on Bench

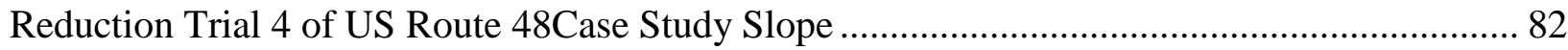

Table 6.8 US Route 48 Bench Removal Feasibility Case Study Overall Results .................. 83

Table 6.9 Geometric Information for US Route 121 Case Study Slope Section ..................... 84

Table 6.10 CRSP-2D Simulation Runs with Various Rockfall Release Zones on Case Study

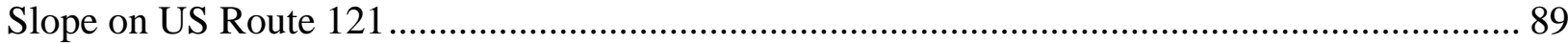

Table 6.11 CRSP-2D Simulation Runs on US Route 121 Slope Case Study: Bench Reduction

Case 1

Table 6.12 CRSP-2D Simulation Runs on US Route 121 Case Study Slope: Bench Removal Trial 2

Table 6.13 CRSP-2D Simulation Runs on US Route 121 Case Study Slope: Bench Removal

Trial 3 97

Table 6.14 US Route 121 Bench Removal Feasibility Case Study Overall Results ................ 98

General Information collected from Soft Bedrock CRSP-2D Calibration Site 2 ……............... 133

Completed Cell Identification Table for Soft Bedrock Calibration Site 2.................................. 133

Completed Rockfall Tally Table for Soft Bedrock Calibration Site 2...................................... 134

Trial-and-Error CRSP-2D Calibration for Soft Bedrock Calibration Site 2 …........................... 135

General Information collected from Hard Bedrock CRSP-2D Calibration Site 2 ...................... 136 
Completed Cell Identification Table for Hard Bedrock Calibration Site 2 ........................... 136

Completed Rockfall Tally Table for Hard Bedrock Calibration Site 2 .................................. 137

Trial-and-Error CRSP-2D Calibration for Hard Bedrock Calibration Site 2 ......................... 138 


\section{INTRODUCTION}

Within the last forty years, there has been a push to construct new large highways in West Virginia to help open up the state for business and tourism. In the years prior, most of West Virginia's highways were small, winding, and worn-out. But with the additional funding provided by the Appalachian Development Highway System (ADHS), engineers were able to construct highways that cut through the mountains, instead of around (ARC, 2013). With these new highways being constructed throughout West Virginia's mountainous terrain, highway engineers are often given the challenge of designing large rock cut slopes. The biggest concern for any engineer is safety, so the mitigation of rockfall is always a focus in cut slope design. Current West Virginia guidelines and directives focus on implementing geotechnical benches to aid in both slope stability and rockfall mitigation, but proper maintenance is not always possible to ensure benches function properly. Advancements in computer modeling have allowed accurate testing of design alternatives for cut slopes to determine if a reduction in benches is feasible, safe, and economical.

\subsection{Research Purpose and Objectives}

The purpose of this project was to determine the effectiveness, in terms of rockfall mitigation, of current West Virginia Department of Transportation rock cut slope design standards with the aid of rockfall simulation computer software. Additionally, it was desired to determine the feasibility, in terms of structural stability and roadway user safety, of geotechnical bench removal in highway rock cut slopes designed to the West Virginia DOT standards by using 2dimensional computer modeling. Additionally, other state transportation agency cut slope design methods were investigated and compared to current West Virginia DOT guidelines to create a comprehensive and up-to-date design guide for highway rock cut slopes.

\subsection{Research Scope of Work}

- Conduct literature review on other state transportation agencies' highway rock cut slope guidelines and compare to current practices of West Virginia DOT.

- Develop a Rockfall Hazard Rating System (RHRS) for new rock cut slopes which will aid in organization of the agency's rock cut slope database and determine how to allocate resources for remediation and improved safety of the cut slopes.

- Use RHRS to determine the highway rock cut slopes in West Virginia that are considered the most hazardous and in need of remediation to mitigate rockfall risks to roadway users.

- Calibrate Colorado Rockfall Simulation Program Version 4.0 (CRSP-2D) for West Virginia topography and geology.

- Use CRSP-2D to run a sensitivity analysis on highway rock cut slope designed to WVDOT standards to determine which slope characteristics cause the highest rockfall runout.

- Use the analysis of newly designed and built rock cut slopes in West Virginia and CRSP$2 \mathrm{D}$ simulations to aid in the determination of whether bench removal on highway rock cut slopes is feasible and safe. 


\section{LITERATURE REVIEW}

The purpose of the literature review was to investigate the following:

- An introduction to rockfall, including the locations prone to rock failure, the root causes of rockfall, and the possible rockfall mitigation tactics.

- West Virginia Department of Transportation's current rock cut slope design guidelines, as well as a comparison to other state transportation agency guidelines. The states selected have similar topography and geology to West Virginia, and include: Pennsylvania, Ohio, Colorado, Montana, and Oregon.

- An overview of the modeling software used in this research.

\subsection{Rockfall}

There are two classifications of landslide types that deal with rockfall: topples and falls (OHDOT, 2007). A topple is a forward rotation out of the slope of mass of soil or rock about a point or axis below the center of gravity of the displaced mass. Toppling is sometimes driven by gravity exerted by material upslope of the displaced mass. A topple can also occur due to water or ice in the cracks of the rock mass. The cracks in the rock mass can be due to discontinuities and stratification of the material. Common causes of a topple include vibrations, undercutting, differential weathering, excessive excavation, and erosive forces. Topples can be independent events, or can lead to a fall if occurring high up on a slope.

A fall starts with a detachment of soil and or rock from a steep slope along a surface in which little or no shear displacement occurs. The detached material descends primarily through the air by falling, bouncing, or rolling down the remaining slope. Falls generally occur on slopes with angles ranging from 45 to 90 degrees and are caused by vibrations, undercutting, differential weathering, and erosion. Falls are generated from discontinuities in the rock or soil, creating weak points for failure. Falls can be especially dangerous near roadways or above residential areas. Falls can be easily classified by debris or rubble found at the toe of the slope. Catchment structures are the primary mode of confining the fallen debris and keeping debris from entering roadways (Das, 2006).
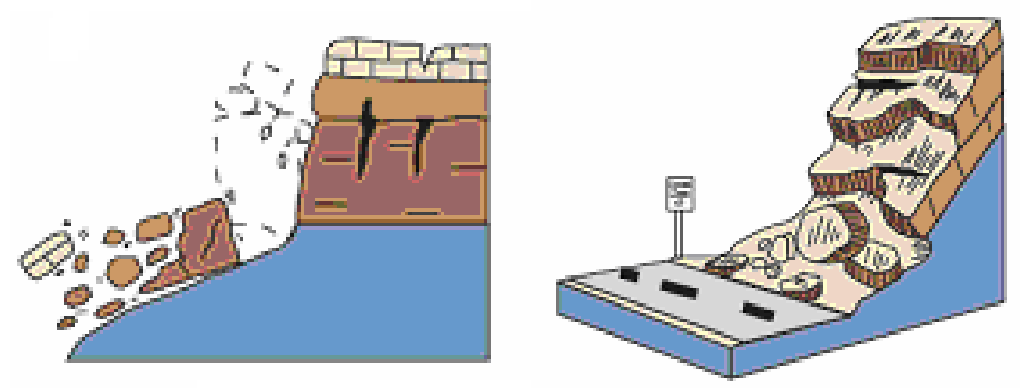

Figure 2.1 Illustration of a "topple" slope failure (left) and a "fall" slope failure (right). (OHDOT 2007)

The combination of topples and falls on highway rock cut slopes are a serious concern for roadway users. It is important for transportation agencies to properly mitigate any rockfall hazards that may occur on a cut slope before they reach the roadway below. The first step in proper mitigation is to determine the root causes of rockfall. The most common causes of rockfall are rock slope overblasting, adverse rock strata configuration, erosive forces, and other hydrological effects including freeze-thaw cycles. Identifying the main causes of rockfall on a given rock cut slope is critical in the mitigation process. Hazard rating systems have been 
developed by state transportation agencies to identify these issues, and will be discussed in Section 2.3.

\subsubsection{Rockfall Attenuation and Mitigation Methods}

Oftentimes, rockfall cannot be completely prevented. This is due to a combination of the causes listed in the previous section. When rockfall does occur, transportation agencies need to develop ways of retaining the falling rocks before reaching the roadway. Many techniques are used, with the selection based on cost, right-of-way availability, and aesthetic preferences. Mitigation techniques are typically broken down into two categories: on-slope attenuation, and toe-of-slope mitigation. On-slope methods include netting, rock bolting, and shotcreting. Toe-of-slope methods include barriers, fences, and catchment ditches. Properly designed catchment ditches are the most common type of rockfall mitigation technique.

\subsubsection{Rockfall Catchment Area Design (RCAD)}

Developed from Arthur Ritchie's 1963 study on rockfall control, Oregon's Department of Transportation created and validated rockfall catchment ditch designs for highway rock cut slopes (ODOT, 2001). Depending on the height and angle of the backslope, ditch geometry must be modified to retain $90 \%$ of falling rocks prior to the roadway. This percentage is a design standard for the Oregon DOT. In addition to adequate retention, the exiting ditch slope is at a ratio of $4 \mathrm{H}: 1 \mathrm{~V}$ or shallower, which creates a recoverable surface for vehicles and removes the need for guiderails. ODOT developed ditch design charts for backslopes ranging from vertical to $1 \mathrm{~V}: 1 \mathrm{H}$ and heights up to 80 feet. While the backslopes within the research were typically much higher, the RCAD guidelines aided in the development of catchment ditches for slopes in West Virginia (see Section 4.3.3).

\subsection{WVDOT Rock Cut Slope Design Guide}

The State of West Virginia Department of Highways guidance document for the recommendations and guidelines for rock cut slopes is Design Directive number 403 (WV DD403). The document was implemented in July of 2006. The WVDOT also uses the WVDOT Standard Specifications for supplemental guidelines in both design and construction of cut rock slopes.

WV DD-403 begins by identifying the three key principles involved in correctly designing a highway rock cut slope: attempt to keep slope maintenance and, thus, maintenance costs to a minimum; attempt to keep construction costs to a minimum by designing the slope as steep as possible while remaining structurally stable; and design to the type of bedrock, since each type poses different potential engineering issues (WVDOH, 2006).

The following section in WV DD-403 provides a discussion on key design issues encountered with specific bedrock types found in West Virginia. For example, the document recommends designing slopes consisting of Red Bed Shales at backslope ratios of 1:1 or shallower due to known erosion issues with this bedrock type (WVDOH, 2006). Additional bedrock types discussed include sandstone, limestone, Permian period bedrocks, and lake sediments.

The following sections in DD-403, including specific design guidelines and values, are broken down into four distinct cut slope types, based on the bedrock exposed in the cut:

Type 1. Cut consisting of hard and medium-hard limestone and sandstone, as well as hard shale. Weaker material, such as soft shale and coal, can only occur in small seams in a Type 1 slope. (WVDOH, 2006) 
Type 2. Cut consisting of soft limestone and sandstone, medium-hard shale and siltstone, or interbedded combinations. A large portion of West Virginia is made up of this type of bedrock composition. (WVDOH, 2006)

Type 3. Cut consisting of soft shale, interbedded with siltstone, sandstone, or limestone. Without the interbedding of stronger material, this would be a Type 4 cut slope. (WVDOH, 2006)

Type 4. Cut consisting of soft to very soft shale. These cuts are highly erosive and are often designed as clay slopes. (WVDOH, 2006)

Following the cut slope type descriptions, WV DD-403 has discussions on designing slopes with adverse dip conditions and/or intensely fractured bedrock. Lastly, the document goes into design specifics, including proper benching procedures, backslope angles and heights, and overburden design. Some of the key design suggestions the document makes are as follows (WVDOH, 2006):

- Slopes with backslope ratio of 1:1 or steeper should have a bench 5 feet above ditch grade, and then additional benches constructed at a spacing of 50 to 70 feet, depending on cut slope type.

- Bench width should be between $1 / 2$ and 2/5 of the distance between benches. Exact width selection depends on the cut slope type. Additionally, the bench should have a slope of $15 \mathrm{H}: 1 \mathrm{~V}$, facing the roadway.

- Backslope angle is highly dependent on cut slope type. Backslopes may be as steep as 1H:6V for Type 1 cuts, or as shallow as 1:1 for Type 4 cuts.

- A Factor of Safety is the minimum acceptable value for long term stability; this value should be increased to 1.50 if the roadway is considered an arterial.

Design cross-section example figures are located at the end of WV DD-403, one for each cut slope type.

\subsubsection{Other State Agency Practices}

In addition to a comprehensive review of West Virginia DOT's current rock cut slope design practices, the following state transportation agencies' guidelines were reviewed for comparative purposes: Oregon (ODOT), Montana (MDOT), Ohio (OHDOT), Colorado (CODOT), Pennsylvania (PennDOT), Vermont (VTrans). These state agencies were selected due to similarities in topography and geology with West Virginia. Table 2.1 shows a comparison of rock cut slope design and construction practices by the WVDOT that differ from these other state transportation agencies. While there is no justification that the recommendations or values listed in other state agencies' guidelines are more or less accurate than those used by WVDOT, many areas of concern when dealing with rock cut slopes are not even discussed in WVDOT guideline documents. While Table 2.1 is not comprehensive of all state transportation agencies, it does show where West Virginia DOT may improve their guidance documents for more stable and safer highway rock cut slopes. 
Table 2.1 Comparison of WVDOT Rock Cut Slope Guidelines with other State Transportation Agencies

\begin{tabular}{|c|c|c|c|}
\hline Criteria & $\begin{array}{c}\text { Documented WVDOT } \\
\text { Practice }\end{array}$ & $\begin{array}{c}\text { Other State Agency } \\
\text { Practice(s) }\end{array}$ & $\begin{array}{c}\text { State Transportation } \\
\text { Agency(s) }\end{array}$ \\
\hline $\begin{array}{c}\text { Stability Factor of } \\
\text { Safety }\end{array}$ & $\begin{array}{c}\text { Minimum of } 1.25 \\
\text { (Minimum of } 1.50 \text { for } \\
\text { arterial roads) }\end{array}$ & $\begin{array}{c}\text { Minimum of } 1.50 \text { for all } \\
\text { roadways }\end{array}$ & MDOT \\
\hline $\begin{array}{c}\text { Rockfall Rating } \\
\text { System }\end{array}$ & No practice & RHRS & $\begin{array}{l}\text { CODOT, MDOT, } \\
\text { OHDOT, PennDOT, } \\
\text { ODOT, VTrans }\end{array}$ \\
\hline $\begin{array}{c}\text { Rockfall Catchment } \\
\text { Practices }\end{array}$ & Barriers, fences & $\begin{array}{l}\text { Rockfall Catchment } \\
\text { Area Design (RCAD) }\end{array}$ & ODOT \\
\hline \multirow[t]{2}{*}{$\begin{array}{l}\text { Rockfall Retention } \\
\text { Guidelines }\end{array}$} & \multirow[t]{2}{*}{ No stated practice } & $\begin{array}{l}\text { Max. of } 10 \% \text { falling } \\
\text { rocks reach roadway }\end{array}$ & ODOT \\
\hline & & $\begin{array}{l}\text { Max. of 5\% falling } \\
\text { rocks reach roadway }\end{array}$ & OHDOT \\
\hline $\begin{array}{l}\text { Slope Stability } \\
\text { Analysis }\end{array}$ & $\begin{array}{l}\text { General Limit } \\
\text { Equilibrium }\end{array}$ & $\begin{array}{l}\text { GLE and Computer } \\
\text { Analysis Software }\end{array}$ & $\begin{array}{c}\text { PennDOT, MDOT, } \\
\text { ODOT }\end{array}$ \\
\hline Material Testing & $\begin{array}{l}\text { Compressive strength, } \\
\text { slake durability }\end{array}$ & $\begin{array}{l}\text { Compressive strength, } \\
\text { slake durability, shear } \\
\text { strength, RQD, Point } \\
\text { load testing, sulfur } \\
\text { testing }\end{array}$ & $\begin{array}{c}\text { PennDOT, OHDOT, } \\
\text { VTrans }\end{array}$ \\
\hline $\begin{array}{c}\text { Safe Blasting } \\
\text { Techniques }\end{array}$ & Pre-splitting & $\begin{array}{l}\text { Pre-splitting, trim } \\
\text { blasting, line drilling }\end{array}$ & $\begin{array}{l}\text { ODOT, PennDOT, } \\
\text { MDOT }\end{array}$ \\
\hline
\end{tabular}

\subsection{Rockfall Hazard Rating System}

With an expanding highway system in West Virginia comes an increasing number of rock cut slopes to properly construct, monitor, and maintain. With numerous slopes in various conditions, there is a need for a classification and organization system to properly allocate resources to produce the safest roadway system for users.

\subsubsection{History}

Many state transportation agencies use a system called the Rockfall Hazard Rating System (RHRS), developed by Oregon Department of Transportation in 1991. RHRS is intended to give transportation agencies the ability to proactively address their rockfall hazards instead of reacting to rockfall incidents after they occur (Pierson, 1991). Trained personnel "rate" rock cut slopes throughout the state to develop a database of total scores. The more hazardous, or potentially troublesome, slopes can then be identified by score comparison. To further aid in the identification of the "worst" slopes, an exponential system of score possibilities (from 3 to 81) provide a rapid increase in scores that quickly distinguishes the more hazardous sites (Pierson, 
1991). The initial RHRS rating categories developed by ODOT were: slope height, ditch effectiveness, average vehicle risk, percent of decision sight distance, roadway width, structural condition of joints, rock friction, erosion rate, size/volume of rockfall events, climate and presence of water on slope, and rockfall history. Table 2.2 shows the original Rockfall Hazard Rating System for 1991. Each of these categories have accompanying detailed descriptions for rating technicians to use when in the field to aid in accurate score selections for each category. These descriptions can be found in Appendix I. As other state transportation agencies have adopted this system throughout the years, each has modified the system to meet the potential hazards of the topography and geology of that state. As of the time of this project, West Virginia Department of Transportation does not use any form of RHRS to monitor the highway rock cut slopes within the state.

Table 2.2 Original Rockfall Hazard Rating System (Pierson, 1991)

\begin{tabular}{|c|c|c|c|c|c|c|}
\hline \multirow{2}{*}{\multicolumn{3}{|c|}{ Category }} & \multicolumn{4}{|c|}{ Rating Criteria and Score } \\
\hline & & & 3 Points & 9 Points & 27 Points & 81 Points \\
\hline \multicolumn{3}{|c|}{ Slope Height } & 25 Feet & 50 Feet & 75 Feet & 100 Feet \\
\hline \multicolumn{3}{|c|}{ Ditch Effectiveness } & Good Catchment & $\begin{array}{l}\text { Moderate } \\
\text { Catchment }\end{array}$ & $\begin{array}{l}\text { Limited } \\
\text { Catchment }\end{array}$ & No Catchment \\
\hline \multicolumn{3}{|c|}{ Average Vehicle Risk } & $25 \%$ of the time & $50 \%$ of the time & $75 \%$ of the time & $100 \%$ of the time \\
\hline \multicolumn{3}{|c|}{$\begin{array}{c}\text { Percent of Decision Sight } \\
\text { Distance }\end{array}$} & $\begin{array}{l}\text { Adequate sight } \\
\text { distance, } 100 \% \\
\text { of low design } \\
\text { value }\end{array}$ & $\begin{array}{l}\text { Moderate sight } \\
\text { distance, } 80 \% \text { of } \\
\text { low design value }\end{array}$ & $\begin{array}{l}\text { Limited sight } \\
\text { distance, } 60 \% \text { of } \\
\text { low design value }\end{array}$ & $\begin{array}{l}\text { Very limited } \\
\text { sight distance, } \\
40 \% \text { of low } \\
\text { design value }\end{array}$ \\
\hline \multirow{4}{*}{ 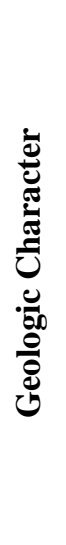 } & \multirow{2}{*}{ 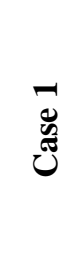 } & $\begin{array}{l}\text { Structural } \\
\text { Condition }\end{array}$ & $\begin{array}{l}\text { Discontinuous } \\
\text { joints, favorable } \\
\text { orientation }\end{array}$ & $\begin{array}{l}\text { Discontinuous } \\
\text { joints, random } \\
\text { orientation }\end{array}$ & $\begin{array}{l}\text { Discontinuous } \\
\text { joints, adverse } \\
\text { orientation }\end{array}$ & $\begin{array}{l}\text { Continuous } \\
\text { joints, adverse } \\
\text { orientation }\end{array}$ \\
\hline & & $\begin{array}{l}\text { Rock } \\
\text { Friction }\end{array}$ & Rough, irregular & Undulating & Planar & $\begin{array}{l}\text { Clay infilling, or } \\
\text { slickensided }\end{array}$ \\
\hline & \multirow{2}{*}{ 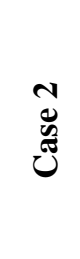 } & $\begin{array}{l}\text { Structural } \\
\text { Condition }\end{array}$ & $\begin{array}{l}\text { Few differential } \\
\text { erosion features }\end{array}$ & $\begin{array}{l}\text { Occasional } \\
\text { erosion features }\end{array}$ & $\begin{array}{l}\text { Many erosion } \\
\text { features }\end{array}$ & $\begin{array}{l}\text { Major erosion } \\
\text { features }\end{array}$ \\
\hline & & $\begin{array}{l}\text { Difference } \\
\text { in Erosion } \\
\text { Rates }\end{array}$ & Small difference & $\begin{array}{l}\text { Moderate } \\
\text { difference }\end{array}$ & Large difference & $\begin{array}{l}\text { Extreme } \\
\text { difference }\end{array}$ \\
\hline \multicolumn{3}{|c|}{$\begin{array}{l}\text { Block Size / Volume of } \\
\text { Rockfall Event }\end{array}$} & $\begin{array}{l}1 \text { Foot / } 3 \text { Cubic } \\
\text { Yards }\end{array}$ & $\begin{array}{l}2 \text { Feet / } 6 \text { Cubic } \\
\text { Yards }\end{array}$ & $\begin{array}{l}3 \text { Feet / } 9 \text { Cubic } \\
\text { Yards }\end{array}$ & $\begin{array}{l}4 \text { Feet / } 12 \text { Cubic } \\
\text { Yards }\end{array}$ \\
\hline \multicolumn{3}{|c|}{$\begin{array}{c}\text { Climate and Presence of } \\
\text { Water on Slope }\end{array}$} & $\begin{array}{l}\text { Low to moderate } \\
\text { precipitation; no } \\
\text { freezing periods; } \\
\text { no water on } \\
\text { slope }\end{array}$ & $\begin{array}{l}\text { Moderate } \\
\text { precipitation or } \\
\text { short freezing } \\
\text { periods or } \\
\text { intermittent } \\
\text { water on slope }\end{array}$ & $\begin{array}{l}\text { High } \\
\text { precipitation or } \\
\text { long freezing } \\
\text { periods or } \\
\text { continual water } \\
\text { on slope }\end{array}$ & $\begin{array}{l}\text { High } \\
\text { precipitation and } \\
\text { long freezing } \\
\text { periods or } \\
\text { continual water } \\
\text { on slope and long } \\
\text { freezing periods }\end{array}$ \\
\hline \multicolumn{3}{|c|}{ Rockfall History } & Few falls & Occasional falls & Many falls & Constant falls \\
\hline
\end{tabular}




\subsubsection{RHRS for New Cut Slopes}

Since development in 1991, common practice has been to use the Rockfall Hazard Rating System for existing rock cut slopes, or those in consideration for remediation (Pierson, 1991). RHRS evaluates the rock cut slope's proneness to rockfall events along with the roadway user's risk of being affected by a rockfall event. An accumulation of a slope RHRS inventory allows the user to identify slopes with higher scores that translates to a more urgent need of remediation. This allows for a better allocation of funding and resources to reduce the risk of rockfall events affecting roadway users.

A similar process has recently been developed for newly constructed rock slopes, or those still in the design phase, by the Federal Highway Administration (FHWA). In a report entitled "Use of Rockfall Rating Systems in the Design of New Slopes," published in the seventh geotechnical practice publication GeoChallenges: Rising to the Geotechnical Challenges of Colorado, the idea of using a modified RHRS to develop a standard of practice for designing rock slopes based on risk is presented. By balancing rating categories between "Probability of failure" and "Consequences of failure," an overall risk for a new slope can be determined. When an inventory of rating scores is compiled, the user can set a "risk threshold" that all new slopes should score beneath. This threshold would need to be developed and calibrated under the user's discretion. Additionally, some RHRS categories would need modified, such as "presence of water on slope?" and "rate of erosion?" to account for the absence of existence of the slope in question. This can be done by observing similar slopes, local climate, borehole logs, and construction plans to rate the slope in place of field observations (Anderson, 2013).

\subsection{Computer Modeling}

Due to the development of computer modeling over the last two decades, highway rock cut slopes can be developed and evaluated for feasibility without physically constructing the slope. Computer programs can analyze rock cut slopes for stability, simulate rocks falling down the slopes to determine safety, and record precise locations and other attributes of slopes on a map for organization.

\subsubsection{Colorado Rockfall Simulation Program}

A combination of multiple techniques should be used to attenuate rockfall events reaching the roadway. When designing a rock cut slope, there are many good practices that can be incorporated into the design to ensure the minimum amount of rockfall events reaching the roadway, widening of benches, implementation of Ritchie Ditch design, and adding fences or barriers to the toe of slope. Rockfall simulation software can aid in the determination of the selection of the safest and most cost effective approach to the mitigation of rockfall events. Colorado Rockfall Simulation Program, or CRSP, is the most commonly used commercially available rockfall simulation program in the United States. It was originally developed in 1988 by Dr. Jerry D. Higgins and Timothy J. Pfeiffer at the Colorado School of Mines, and was funded by the Colorado Department of Transportation. Current version of the software include 2-Dimensional Version 4.0 (Jones, 2000) and 3-Dimensional Version 1.0 (Andrew, 2012). In both the 2-D and 3-D versions, the program uses input parameters including slope dimensions and geometry, slope material properties, and rockfall shape and size to simulate the trajectory of rockfall events on the slope. The program does not predict whether or not rockfall events will occur (cause), but rather the paths and final location(s) of the rocks when these events do occur on the slope (effect). CRSP is used by many transportation agencies and consulting companies in industry practices. State transportation agencies that cite using CRSP as an analysis tool include Colorado, Ohio, Oregon, and California. 
The 2-Dimensional program uses an algorithm that models a rock falling down a slope as a series of short bounces (Jones, 2000). The equations in the algorithm include an iterative process between slope angle on impact and tangential, normal, and rotational velocities. These equations are calculated at each rock bounce to find the height and distance travelled before next contact with the slope. If the distance between bounces is less than the rock's radius, the rock is considered to be rolling. In contrast, the 3-Dimensional program was upgraded to using an algorithm that is a more fundamentally physical computational model approach (Andrew, 2012). Discrete Element Method (DEM) and more advanced equations of motion that model the reaction in a collision between two rocks were used to create more realistic results. Even though the 3-Dimensional version appears to have a more advanced simulation method, the 2Dimensional version remains more heavily used in the industry.

\subsubsection{Features of CRSP Version 4.0 (2-Dimensional)}

The accuracy of the rockfall simulations within CRSP-2D depend on three key slope parameters: surface roughness $(S)$, normal coefficient of restitution $\left(R_{n}\right)$, and tangential coefficient of frictional resistance $\left(R_{t}\right)$ (Jones, 2000). The surface roughness is the measure of the irregularity of the slope surface; more specifically it is the perpendicular variation from an average plunge line over a distance equal to the radius of the fallen rock. Typical ranges for surface roughness range between 0.0 and 2.0 for manmade slopes, but can be larger for rougher surfaces. The two coefficient values, $\mathrm{R}_{\mathrm{n}}$ and $\mathrm{R}_{\mathrm{t}}$, range between 0.01 to 1.0 , and relate to the transfer of elastic energy during the bounces. The normal coefficient attenuates the falling rock's velocity normal to the slope, while the tangential coefficient attenuates the falling rock's tangential velocity.

Normal and tangential coefficient values closer to 1.0 than zero, which are associated with harder slopes such as solid rock, allow the falling rock to retain its velocity and travel farther down the slope, thus creating a larger hazard to roadway users. Each of these three values $\left(S, R_{n}\right.$, and $\left.R_{t}\right)$ must be recorded for each "cell," or segment, of the slope profile, and may vary greatly in number from cell to cell depending on the geological configuration of the slope. These inputs have a large role in the trajectory of the rockfall, and there is a very high sensitivity for each of these parameters, so the user must be accurate in the selection of the proper values. CRSP Version 4.0 Manual lists suggested ranges of values for each of these parameters based on surface material type (see Tables 2.3 and 2.4 below) (Jones, 2000). However, due to the large, imprecise ranges of suggested values for both $R_{n}$ and $R_{t}$, calibration to identify precise values is necessary. This will be discussed in the Calibration section (Section 4.2).

Table 2.3 General Tangential Coefficient Ranges for Different Slope Surface Types (Jones, 2000)

\begin{tabular}{|l|c|l|}
\hline \multicolumn{1}{|c|}{ Description of Slope } & Tangential Coefficient $\left(\mathbf{R}_{\mathbf{t}}\right)$ & \multicolumn{1}{|c|}{ Remarks } \\
\cline { 1 - 2 } $\begin{array}{l}\text { Smooth hard surfaces and } \\
\text { paving }\end{array}$ & $0.90-1.0$ & $\begin{array}{l}\text {-Use lower } \mathbf{R}_{\mathrm{t}} \text { as density of } \\
\text { vegetation on the slope increases. }\end{array}$ \\
\cline { 1 - 2 } $\begin{array}{l}\text { Most bedrock and boulder } \\
\text { fields }\end{array}$ & $0.75-0.95$ & \\
\cline { 1 - 2 } Talus and firm soil slopes & $0.65-0.95$ & \\
\cline { 1 - 2 } Soft soil slopes & $0.50-0.80$ & \\
\hline
\end{tabular}


Table 2.4 General Normal Coefficient Ranges for Different Slope Surface Types (Jones, 2000)

\begin{tabular}{|c|c|c|}
\hline Description of Slope & Normal Coefficient $\left(\mathbf{R}_{\mathbf{n}}\right)$ & Remarks \\
\hline $\begin{array}{l}\text { Smooth hard surfaces and } \\
\text { paving }\end{array}$ & $0.60-1.0$ & \multirow{4}{*}{$\begin{array}{l}\text {-If max. velocity is desired } \\
\text { output, use lower values in range } \\
\text { If average velocity is desired } \\
\text { output, use higher values in } \\
\text { range. }\end{array}$} \\
\hline $\begin{array}{l}\text { Most bedrock and boulder } \\
\text { fields }\end{array}$ & $0.15-0.30$ & \\
\hline Talus and firm soil slopes & $0.12-0.20$ & \\
\hline Soft soil slopes & $0.10-0.20$ & \\
\hline
\end{tabular}

In addition to the aforementioned parameters, the 2-Dimensional version of CRSP allows the user to select the shape, dimension, and density of the rockfall. Shape choices are spherical, cylindrical, and discoidal. The selection of a specific shape both contributes to the randomness of rockfall behavior as it contacts the slope face, and influences the apportionment of translational and rotational energy through the moment of inertia of the shape (Jones, 2000). The user can only input one shape and one size of rock for each trial, so the "worst case" should be determined and represented by selecting the rock dimensions that causes the highest percentage of rocks to reach the roadway. The user should select the density of the rock from published values for the rock type observed in the field. The $R_{t}$ and $R_{n}$ values for the rockfall will be the same as those input for the slope segment where the rockfall originates. After selection of all these parameters, a simulation can be properly run.

In addition to the "worst case" assumption listed above, the 2-Dimenional version of CRSP has the following assumptions and limitations:

- Since slopes often vary greatly in the third dimension, it is important to find the twodimensional slope profile that is most representative of the entire slope (or the "worst case" if desired).

- Rocks are not often in the shape of spheres, cylinders, or discs, the only shape options available in the software. Thus, calibration is necessary to decide which shape behaves most similar to what was observed in the field. Spherical rocks provide the maximum volume for a given radius and thus are often used for "worst case" trials.

- The program requires initial $\mathrm{x}$ - and $\mathrm{y}$-direction velocities for the rockfall, with a limit of $1 \mathrm{ft} / \mathrm{sec}$. This may affect the behavior of the rockfall in a way that is not accurate to how rocks behave in the field.

- It is stated within the CRSP-2D Manual (Chapter 7) that it bounce height, rockfall runout, and angular velocity have not been calibrated with field observations and thus the developers cannot confirm that the program calculations are accurate for these phenomena.

\subsubsection{Features of CRSP 3-Dimensional Version 1.0}

The 3-Dimensional version of the program was developed by Yeh and Associates, Inc. along with Summit Peak Technologies, LLC in 2006 and released to the public in 2011. This version of CRSP also uses input parameters, but has simplified the process to only include surface roughness ( $S$ ) and a combination of $R_{n}$ and $R_{t}$ called the "hardness coefficient." The hardness coefficient takes into account how the slope material (soft clay, hard rock, grassy soil, etc.) affects the amount of energy transferred from the falling rock to the slope surface upon impact (Andrews, 2012). This takes into account both the normal and tangential velocities that are considered separate entities in the 2-D version. Additionally, within the 3-D program, the user 
may input a range of values for either coefficient (also option for rockfall dimensions) instead of just one input value per simulation as in the 2-Dimensional version. The program then randomly selects a value within the given range for each rock in a simulation.

Additional advancements within the three-dimensional version of CRSP include:

- The user can select from a total of five rockfall shapes to imitate field observations, including spherical, cylindrical, discoidal, tetrahedral, and prismatic (blocky).

- If LiDar scans of the slope are readily available, they can be input into the threedimensional version to create more accurate representations of the field geometry without the need of manual input of $\mathrm{x}-, \mathrm{y}-$, and $\mathrm{z}$ - coordinates.

- Different slope materials can be placed on the slope profile without the need for additional "cells." The materials do not even need to be homogenous in the y-direction.

- The three-dimensional program is overall much more user-friendly than the twodimensional program. The ability to copy-and-paste geometric data from Microsoft Excel files, the color-coded visual representation of different materials within the slope, and the excessive final report details are ways where upgrades have made the program much more accessible to the user.

There are, however, still some limitations to CRSP-3D. The biggest potential issue, especially when working with smaller slopes ( $<500$ feet from toe to crest), is that the slope model is limited to a 12-foot surface resolution. Attempting to enter points on the slope less than 12 feet apart will be ignored by the program and a more generalized slope will be constructed. This is an issue when constructing small benches or strata layers, as will be seen in future sections. Additionally, and perhaps due to the resolution limitations, rocks with a mass less than approximately 100 pounds will not simulate properly within the 3-dimensional program. They tend to not move down the slope, even on steep angles. Thus, when attempting to simulate smaller-diameter (and thus, smaller mass) rockfall, the 2-dimensional program must be used.

\subsubsection{SVSlope ${ }^{\circledR}$}

SVSlope $^{\circledR}$ is a slope stability modeling program in a suite of computer software developed by SoilVision Systems, Ltd. The remainder of the suite, called SVOffice ${ }^{\mathrm{TM}} 2009$, contains software dealing with more detailed aspects of geotechnical modeling, including contaminant transport and geothermal modeling. SVSlope ${ }^{\circledR}$ is a finite element method (numerical modeling) analysis software that possesses the capability to analyze slope stability of various manmade earthwork designs. The program uses advanced searching methods, coupled with probabilistic analysis to correctly determine the correction location of each critical slip surface in a geotechnical slope model (SoilVision, 2011). The results can be evaluated in multiple ways such as sensitivity analysis, stochastic, or deterministic based upon input data parameters. The end result output of the software is an overall factor of safety for the model, with all potential failure planes displayed to show which portion(s) of the model are the most prone to failure. The factor of safety is determined by the material, geometric, and analysis method. In addition to the computed factor of safety, a visual output of the projected weakest failure plane is present. SVSlope $^{\circledR}$ is capable of modeling both soil and rock as slope material, due to its capability of using various types of failure criterion (discussed in Section 2.4.2.1). This program can be a very powerful tool when attempting to determine the stability of a highway rock cut slope prior to construction.

\subsubsection{Hoek-Brown Failure Criterion}

Hoek and Brown introduced their failure criterion in an attempt to provide an analysis method for the evaluation required for the civil engineering rock removal and design of underground 
excavation in hard rock (Hoek, 2002). This failure criterion can also be based on small scale blasting for engineered slopes, as was the case with this research. The Hoek-Brown criterion is not widely used in slope stability issues, due to the convenience of the Mohr-Coulomb failure criterion based on usage of shear and normal stress, rather than principal stress calculations involved in Hoek-Brown (Kulbacki, 2014). However, Mohr-Coulomb has the assumption that the rock is initially completely intact, while Hoek-Brown considers fractures in the rock that were in place before the failure stresses were applied. This makes the Hoek-Brown criterion more accurate based on field observations.

The parameters of Hoek-Brown are focused on discontinuities, disturbances, and competency of the rock masses (Kulbacki, 2014). The generalized equations of the base Hoek-Brown failure criterion are Equation 5.1 - 5.4 (Hoek, 2002):

Where:

$$
\sigma_{1}^{\prime}=\sigma_{3}^{\prime}+\sigma_{c i}\left(m_{b} \frac{\sigma_{3}^{\prime}}{\sigma_{c i}}+s\right)^{a}
$$

\section{Equation 5.1}

- $\sigma_{1}^{\prime}$ and $\sigma_{3}^{\prime}=$ major and minor effective principal stresses at failure

- $\sigma_{c i}=$ the uniaxial compressive strength of the intact rock material

- $m_{b}=$ is a reduced value of the material constant $m_{i}$

$$
m_{b}=m_{i} \exp \left(\frac{G S I-100}{27-14 D}\right)
$$

Equation 5.2

- $\quad s=$ constant of the rock material based by the given relationship

Where:

$$
s=\exp \left(\frac{G S I-100}{9-3 D}\right)
$$

Equation 5.3

○ $D=$ degree of disturbance. $D$ is the factor to which the rock mass has been subjected by blast damage and stress relaxation. It varies from 0 for undisturbed in situ rock masses to 1 for highly disturbed rock masses (Hoek, 2002).

○ $G S I=$ Geological Strength Index. GSI is a constant based on the structure and surface conditions of the rock material type. The geological character of rock material, together with the visual assessment of the mass it forms, is used as a direct input to the selection of parameters relevant for the prediction of rock-mass strength (Marinos, 2005). GSI can range from 0 to 90, with higher values equating to stronger rock.

- $a=$ constant of the rock material based by the given relationship

$$
a=\frac{1}{2}+\frac{1}{6}\left(e^{-\frac{G S I}{15}}-e^{-\frac{20}{3}}\right)
$$

\section{Equation 5.4}

\subsubsection{General Limit Equilibrium Analysis Method}

The General Limit Equilibrium method, or "method of slices," is based on static analyses that can be used to derive the Factor of Safety. These analyses are the summation of forces in two directions and the summation of moments about a chosen point of rotation (Kulbacki, 2014). Additionally, an assumption must be made regarding the direction or magnitude of some of the forces involved to make the analysis solvable. This assumption is that there is a relationship between interslice forces that specifies the direction (Rahardjo, 1983). 
The GLE Method allows for the analysis of a non-circular slip surface, which is produced by rock media. While the slip surface begins and ends with a circular portion, the majority of the slip surface is linear. It is assumed that the linear portion is a result of a geological discontinuity (Fredlund, 1981), which are how most failures occur in rock. It is important to note that during the calculation of a non-circular failure the radius of curvature is varying, which results in complex computation which reiterates the benefit of a finite element modeling software.

The main difference between this method and other analysis methods, including Janbu and Bishops Methods, is that the General Limit Equilibrium method takes interslice shear force into consideration (Kulbacki, 2014). The calculations performed to obtain the factor of safety with the General Limit Equilibrium method, takes into account driving moments and forces. Thus, both Janbu and Bishops method calculations are included in the GLE method. This makes GLE Method the preferred method for slope stability analysis (Kulbacki, 2014). An overview of the calculation method can be seen in the Equation 5.5 (Fredlund, 1981).

Where:

$$
F_{m}=\frac{\Sigma\left[c^{\prime} l+(P-u l) \tan \emptyset^{\prime}\right] \mathrm{R}}{\Sigma W_{x}-\Sigma \mathrm{Pf} \pm \mathrm{Aa}}
$$

\section{Equation 5.5}

- $F_{m}=$ computed factory of safety

- $c^{\prime}=$ effective cohesion

- $u=$ pore water pressure (if present)

- $l=$ length of the failure surface at the base of each slice

- $\emptyset^{\prime}=$ effective angle of internal friction

- $\mathrm{P}=$ the total normal force on the base of a slice

- $\mathrm{R}=$ radius of curvature

- $W_{x}=$ the total vertical forces due to the mass of a slice of width ' $b$ ' and height ' $h$ '

- $A=$ the resultant external water forces

- $a=$ the perpendicular distance from the resultant external water forces to the center of rotation

- $\quad \mathrm{Pf}=$ resulting moment of failing mass, independent from slice to slice

\subsubsection{ArcGIS}

Made by Esri, ArcGIS is a popular brand of geographic information system (GIS) software, which links together the use of maps and geographic information. The software is often used by state transportation agencies and research groups to aid in mapping out rock slopes, allowing the user to properly analyze multiple slopes in a large area (Esri, 2012).

GIS software is also being incorporated into computer modeling to help simulate rockfall by allowing the user to accurately locate potential rock instabilities and run-out areas (Jaboyedoff, 2003).

\subsubsection{Jenks Algorithm}

Located within ArcMap, the main user interface program of the ArcGIS suite, is the ability for the program to classify, or rank, map features based on values found in each feature's attribute table. The classification methods available are manual, equal interval, defined interval, geometric interval, quantile, standard deviation, and natural break (Jenks). The first six methods all either have manually entered intervals or evenly spaced intervals. However, the natural breaks method, developed by George Jenks, interprets the data set and determines the best arrangement of values into classes based on where there are natural gaps, or breaks (Jenks, 
1967). A Jenks classification produces the lowest squared deviations of the classification different data class means. This is done through an iterative process of calculating the sum of squared deviations between data classes (SDBC), then calculating the sum of squared deviations between the data set mean $($ SDAM), and finding the difference (SDAM - SDBC $=$ SDCM). Then, after inspecting the SDBC for each class, move one unit from the class with the highest SDBC to the class with the lowest SDBC and recalculate SDCM. Continue this process until the SDCM no longer decreases (Esri, 2004).

The Jenks classification method allows for a collection of data to be sensibly ranked without having any prior knowledge about any relationships within the data. Thus, it is recommended to be included in a Rockfall Hazard Rating System database creation. This is because the effective of an RHRS database relies on identifying the slopes that are most hazardous by comparison of scores. Without having previous knowledge of the relationships within the dataset, the Jenks classification method allows for the proper development of a ranking system so state transportation agencies can allocate resources to remediate the most hazardous slopes (Esri, 2004). 


\section{ROCKFALL HAZARD RATING SYSTEM (RHRS) METHOD DEVELOPMENT}

\subsection{Purpose}

As defined in Section 2.3, RHRS is a very useful way for transportation agencies to document and compare all highway rock cut slopes in a database. This allows the agency to properly allocate resources to the slopes that are most hazardous and thus in need of the most immediate attention. With the idea of an RHRS for newly designed or constructed cut slopes (Section 2.3.2), an agency can also determine which slopes will need bench reconfiguration or additional catchment methods. After using the rating system to determine these slope(s), computer models can be run in both SoilVision SVSlope ${ }^{\circledR}$ and CRSP-2D to determine the proper reconstruction of the hazardous slope in question.

\subsection{Development of System for New Slopes}

A prototype rockfall hazard rating system for new slopes in West Virginia was created for this research based off of the ideas in the FHWA-funded report, "Use of Rockfall Rating Systems in the Design of New Slopes" (Anderson, 2013) along with field observations made while inspecting new slopes in West Virginia. While the original version of RHRS is still a very useful tool, it was modified in this research in an attempt to improve its accuracy of rating both old and new slopes. As recommended by Anderson, the rating categories were evenly distributed between probability and consequences. This was done to cover both sides of rockfall safety: stability analysis (probability) and roadway user safety (consequences). By considering both, a proper rating can be given to a rock cut slope to show both current and future risk. While many of the rating categories were left unchanged from the original RHRS developed in 1991 by Oregon DOT (Table 2.2), some categories and scoring parameters were updated based on field observations made by technicians. Below is a list of the category changes made to the RHRS categories for new cut slopes in West Virginia, along with the rationale for these changes:

- Slope Height: Adjusted to account for distributing the scores amongst taller slopes that are commonly found within the state. The scope of the project is to only inspect rock cut slopes greater than 100 feet in height, thus the lowest score should be for slopes at or under 100 feet, and a linear increase from that point.

- Roadway Width: While it is understood that this category was developed to depict maneuverability room for roadway users to avoid rockfall, it was found more accurate to remove the focus from the user to the rockfall event. Thus, this category was changed to "Distance from toe of slope to pavement." Slopes that are closer to the roadway are more likely to allow rockfall events to reach the roadway, thus greatly increasing the hazard to roadway users.

- Geologic Character Cases: In the initial version of RHRS, these categories are vague to inexperienced technicians. The categories were adjusted to the following: degree of undercutting, erosion rate, dip angle, and structural condition of joints. The rating explanations are more intuitive now, for both older and newer slopes.

- The additional categories were added to the Probability of Failure portion of the system to ensure an even amount of probability categories and consequence categories. These categories were maintenance frequency and large root vegetation.

In Table 3.1, the updated categories have an asterisk next to them. In addition to modifying some categories, many of the descriptions of the ratings needed to be updated to account for different considerations when inspecting new slopes in West Virginia, as opposed to assessing older slopes with the original RHRS. These updated descriptions can be found in the following 
section. The complete RHRS rating table for new cut slopes is shown in Table 3.1. Section 3.3 lists in-field descriptions for each category. The descriptions help new or inexperienced technicians understand how to properly score each category, since there is limited space for descriptions within the actual RHRS rating table. There are a total of 14 rating categories, 7 that describe the probability of failure, and 7 that describe the potential consequences of failure.

Table 3.1 Updated RHRS Rating Table for New Rock Cut Slopes

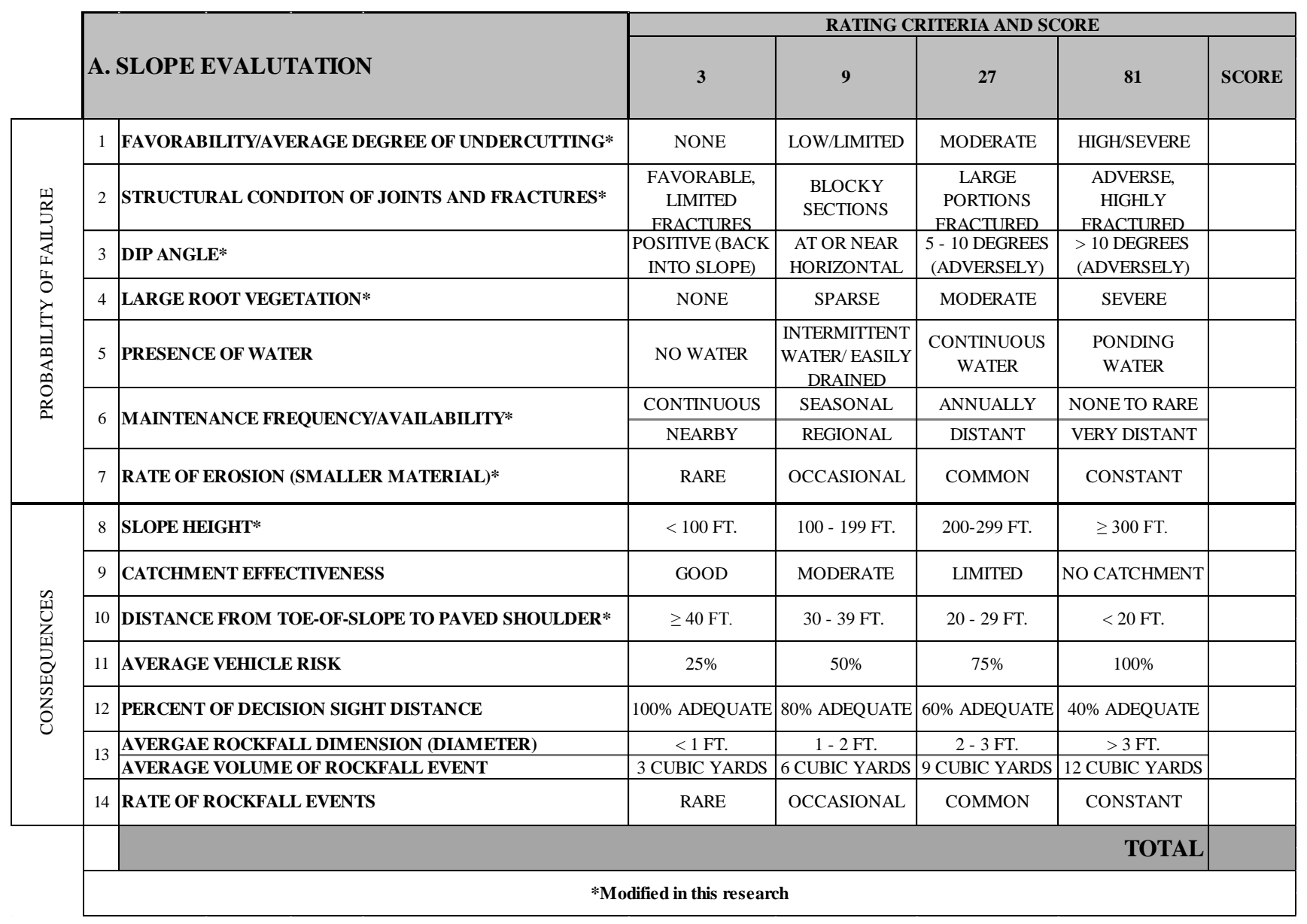

\subsection{RHRS Rating Category Descriptions from Table 3.1:}

1. Favorability/Average Degree of Undercutting - Defines the level of undercutting present on rock blocks on the cut face. The overall score is based the magnitude and number of undercut rock blocks along the slope face. The ranking of the degree of undercutting are as follows:

None: Presence of undercutting is non-existent or very minor

Limited: Very minimal undercutting present but the geologic conditions are in place for the development of additional undercutting

Moderate: Discrete sections of the rock slope have notable undercutting

Severe: Large sections of the slope are undercut and during the presence of a rockfall event could possibly exceed the capacity of the catchment area 
For new slopes, the category title switches to "Favorability" of undercutting in the future. Things to be considered include a benching plan, borehole information, and regional stratigraphic information:

None: A combination of strata configuration and/or bench placement that will result in no undercutting.

Limited: Minimal undercutting can be expected due to strata configuration. However, properly placed benches will remediate larger issues.

Moderate: Even with properly placed benches, undercutting will be unavoidable over multiple sections of the slope.

Severe: Regardless of steps taken, large portions of the slope will have undercutting. During the presence of a rockfall event, the undercutting could possibly exceed the capacity of the catchment area.

2. Structural Condition of Joints and Fractures - In general, the term "adverse" is used to refer to joints that allow block, wedge, planar or toppling failures. "Continuous" refers to very large sections of slope that are composed of one block (no fractures).

Favorable Orientation, limited fractures: Slope contains mostly continuous, un-fractured rock strata.

Blocky sections, otherwise limited fracturing: Slope contains large, sparsely fractured blocks in sections, most of slope remains continuous.

Large portions of slope fractured: Backslopes are highly fractured in many areas throughout slope. There is typically a large range of fracture sizes.

Adverse Orientation, Highly fractured: Backslopes are made up entirely of fractured bedding planes. Large range of fracture sizes. Some failures noticed due to fractured blocks popping out of backslope.

Newly-constructed slopes will be easy to identify joint conditions; however, slopes in a pre-construction phase must be estimated with borehole information and knowledge of rock strata jointing characteristics.

3. Dip Direction and Angle - Reference Figure 3.1 aid in determining the average dip direction and angle of the layers in the slope.

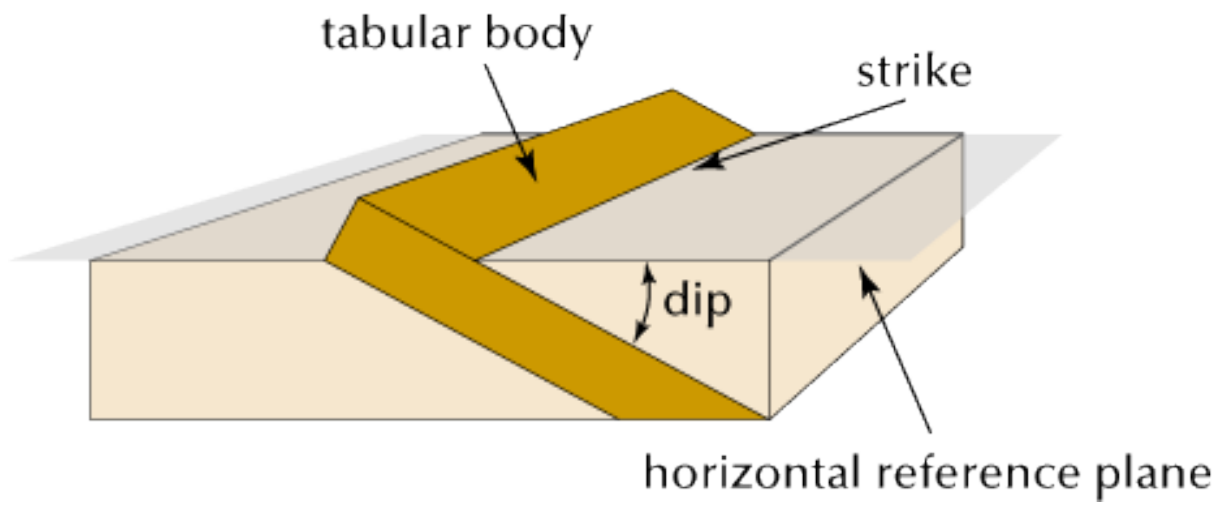

Figure 3.1 Visual Representation of "strike" and "dip" in a bedding plane (Myers 2010).

For pre-constructed slopes, reference the borehole logs and/or neighboring slopes to determine the dip direction and angle. 
4. Large-Root Vegetation - Score associates the relative amount of current and future large-root vegetation (shrubs, trees, etc.) that are present on the slope or benches and will potentially intrude the joints and fractures. For new slopes, reference adjacent/regional slopes, construction plans for vegetation (E\&S reports), and exposed slope materials' nutrient properties.

5. Presence of Water - This category describes the condition of the slope at the time of the evaluation. If water is not currently present but the typical magnitude can be readily estimated, one should rate the slope upon this estimated water level. Presence of springs or any water sources within the slope should be noted, as well as flat areas (benches, etc.) prone to ponding. Lastly, take local climate into consideration.

6. Maintenance Availability/Frequency - This category defines the remoteness of the slope from maintenance personnel, and/or the ability for maintenance personnel to routinely check the slope. Slopes that are unable to be observed/maintained on a regular basis are at a higher risk of failure. New slopes should have a planned routine inspection from nearby maintenance workers on a weekly basis (or more frequently as needed).

7. Rate of Rockfall events and/or Erosion - This category describes the overall rate of which erosive effects are occurring (or will be occurring) on the slope. If one or several strata layers are/will be experiencing higher rates of erosion, the slope shall receive a higher score than if all layers are eroding uniformly, as the possibility for undercutting and rockfall increases with non-uniform erosion. The rate of rockfall was added into this category, since the majority of the "erosion" experienced in a rock cut slope is in the form of rockfall. In pre-constructed slopes, borehole information along with knowledge of rock characteristics must be used.

8. Slope Height - Height of entire slope from toe to crest (From edge of catchment ditch/edge of roadway to crest of slope). Measured in feet, gravitationally vertical.

9. Catchment Effectiveness - Ditch effectiveness is measured by the ability of a catchment area to contain falling rock from reaching the roadway. In estimating the catchment effectiveness, the following factors should be considered:
a. Slope height and angle
b. Ditch width, depth, and shape
c. Anticipated quantity of rockfall per event
d. Impact of slope irregularities on falling rocks

Colorado Rockfall Simulation Program (CRSP) or Oregon DOT's Rockfall Catchment Area Design (RCAD) should be used to assess slope and the percentage of rockfall retained should be categorized as follows:

Good Catchment: All or nearly all rocks are contained in the catchment area

- $\geq 90 \%$ retained

Moderate Catchment: Falling rock occasionally reaches the roadway.

- Between $80 \%$ and $89 \%$ retained

Limited Catchment: Falling rock frequency reaches the roadway

- Between $60 \%$ and $79 \%$ retained 
No Catchment: No catchment area or catchment area is totally ineffective at containing the rockfall. All or nearly all rocks reach the roadway.

- $<60 \%$ retained

10. Distance from toe-of-slope to Paved Shoulder - Measured in feet from edge of paved shoulder to the toe of the rock cut slope (excluding the ditch, if distinguishable).

11. Average Vehicular Risk (AVR) - Measures the amount of time that a vehicle will be present in a rockfall hazard zone. This value is calculated by the using the following slope and roadway parameters: slope length, average daily traffic (ADT), and the posted speed limit at the site. The larger the percentage, the larger the number of vehicles that are present to a slope hazard at any given time. The following equation is used to calculate the average vehicular risk (Pierson, 1991):

$$
\frac{\left.A D T\left(\frac{\text { cars }}{\text { day }}\right) * \text { Slope Lengt } h \text { (miles }\right) / 24\left(\frac{\text { hours }}{\text { day }}\right)}{\text { Posted Speed Limit (M.P.H.) }} * 100 \%=A V R
$$

\section{Equation 3.1}

12. Percent of Decision Sight Distance (DSD) - The decision sight distance is used to determine the length of roadway (feet) that a driver is forced to make a complex or instantaneous decision. The DSD is most significant when driver obstacles are difficult to perceive, or when unexpected or unusual maneuvers are required. The percent decision sight distance is obtained by the ratio of actual measured sight distance to the values given by AASHTO "Policy on Geometric Design of Highways and Streets" (Table 3.2) decision sight distance value (Pierson, 1991).

\section{Table 3.2 Decision Sight Distance}

\begin{tabular}{|c|c|}
\hline Posted Speed Limit (M.P.H.) & Decision Sight Distance (ft.) \\
\hline $\mathbf{3 0}$ & 450 \\
\hline $\mathbf{4 0}$ & 600 \\
\hline $\mathbf{5 0}$ & 750 \\
\hline $\mathbf{6 0}$ & 1000 \\
\hline $\mathbf{7 0}$ & 1100 \\
\hline
\end{tabular}

$$
D S D=\frac{\text { Actual Sight Distance }}{\text { Decision Sight Distance (Coresponding Table } 3.2 \text { value })} * 100 \%
$$

13. Average Rockfall Dimension/ Volume of Rockfall - This measurement should provide a representative size and volume of rockfall event that is most likely to occur. Pick the criterion which supplies the highest score for the slope. Use previous rockfall events or borehole logs and general knowledge of rock behavior to determine the proper rating.

14. Rate of Rockfall Events - Determine the amount of recent rockfall events, and evaluate (via visual clues and the Probability of Failure categories) the rate at which rockfall events will occur on this slope. Knowledge of the age of the slope also helps determine 
the proper rating. For unconstructed slopes, research similar neighboring slopes and knowledge of rock behavior to determine the proper rating.

\subsection{RHRS In-Field Procedure}

After development of the rating system, sites must be selected. To properly assess which slopes need more immediate focus and remediation, a large database of rated slopes must be developed. Thus, it is important to rate as many slopes in the initial stages as possible. While the original RHRS developed by Oregon DOT was to be used on older cut slopes - in which there are typically much more of, the development of this New Rock Cut RHRS requires newer slopes be rated. While slopes 5 years old or newer are most desirable, a slope constructed within the last 10 to 15 years is acceptable. Additionally, a slope that is still in the design or construction phases can be rated if construction plans, borehole logs, and climate information are readily available. In addition to this criterion, the following criteria must also be met to be a RHRSratable slope:

- Slopes must be made up almost entirely of rock. Aside from an overburden section on the top of the slope, slope faces should not be made up of soil.

- Slope must be located on either an arterial or interstate. While cut slopes can be present on collectors and smaller roads, the average daily traffic is much too low to be considered in this application.

- Slopes must be accessible to the rating technicians. While it is not necessary for technicians to physically access the slope or benches, there is a need to measure ditch widths and take other calculations that requires a safe access area.

- Maintenance records and Average Daily Traffic studies must be accessible for the slope. Knowledge of where the nearest maintenance facility is in relation to the slope will also suffice.

- Slope must be located within the same state (West Virginia, in this study) to ensure similarity in construction guidelines and procedures.

To develop an accurate database, slopes with various ranges of potential RHRS scores must be selected, including both high performing slopes and very hazardous slopes. Therefore, the selection of slopes must be random, as long as all aforementioned criteria are met.

Before travelling to the slope location, the technician should acquire the following materials: multiple printouts of the RHRS Rating Table for New Slopes (Table 3.1) and accompanying Category descriptions, measuring tape, range finder, camera, binoculars, and proper roadside safety equipment. Upon arrival to the cut slope section to be rated, the technician should record the precise location in any manner available: GPS coordinates, mile marker for highway, etc. The precision of location is important when inputting the score into a GIS map later on. The technician should then ensure all safety precautions have been made prior to approaching the slope. The original RHRS report (Pierson, 1991) did not provide any type of in-field rating procedure, so the following was developed for use with the newly developed rating system in Table 3.1:

1. Begin by standing near the toe of the slope and using the range finder to get a slope height measurement, and record in notes. While standing at the toe, take a measurement from the toe of the slope to the paved shoulder using the measuring tape. Record this. Categories 8 and 10 can now be answered.

2. Observe the ditch and any other catchment devices present (if any). Using the RHRS Rating Category descriptions in Section 3.3, answer Category 9. If rockfall is present in the ditch area, answer Category 13. 
3. If benches/sides of slope are safely accessible, begin ascending the slope. General observations can aid in answers Categories 4, 13 (if not already answered), and 14 at this point.

4. Focusing on one or more cut backslopes, answer Category 3. After observing and taking notes on all accessible benches backslopes, answer Categories 1, 2, 5, and 7. Return back to ditch level.

5. Observe the roadway, and determine which direction (if 2 lane road) will have the shortest decision sight distance. Use the range finder to determine an estimated distance from the slope section to the portion of roadway where the slope section is first viewable to roadway users. Record this distance, and use the formula in the Category Descriptions to answer Category 12.

6. The final two Categories (6 and 11) must be answered post-site visit. ADT reports can be found online (WVDOT, 2011) to answer Category 11. Category 6 must be answered by either knowledge of maintenance building locations or by contacting WVDOT district personnel.

7. Tally Category ratings to obtain an overall RHRS score for the slope section.

\subsection{Database Development using ArcGIS}

ArcGIS, developed by ESRI, is a popular brand of geographic information system (GIS) software, which links together the use of maps and geographic information. This is a very useful tool when developing an RHRS database, as it allows the user to create an interactive map that not only helps locate every rated slope, but also displays and ranks the scores. The user can also organize the rated sites via WVDOT district to easily notify the proper maintenance personnel or engineers when a slope is deemed hazardous.

Various maps of the state of West Virginia are available online at the WV State GIS Data Clearinghouse (WV GIS Technical Center, 2014), including county maps, geological survey maps, and entire roadway system maps. While all of these can be useful in the development of an RHRS database, only the following downloadable GIS map layers were selected: WVDOT Districts, US Routes, State Routes, and Interstates. This creates a visually cluttered but useful map, which can be seen in Figure 3.1. It is important to ensure that the roadway layers are up to date, especially when rating brand new slopes. Slopes that are still in the construction phase that have been rated will not be added to the database since the road layer does not exist for unconstructed roads. However, the scores for unconstructed slopes will still be compared to the ranking system that is developed in the procedure listed below, and remedial action should be taken if the slopes receive a hazardous ranking. 


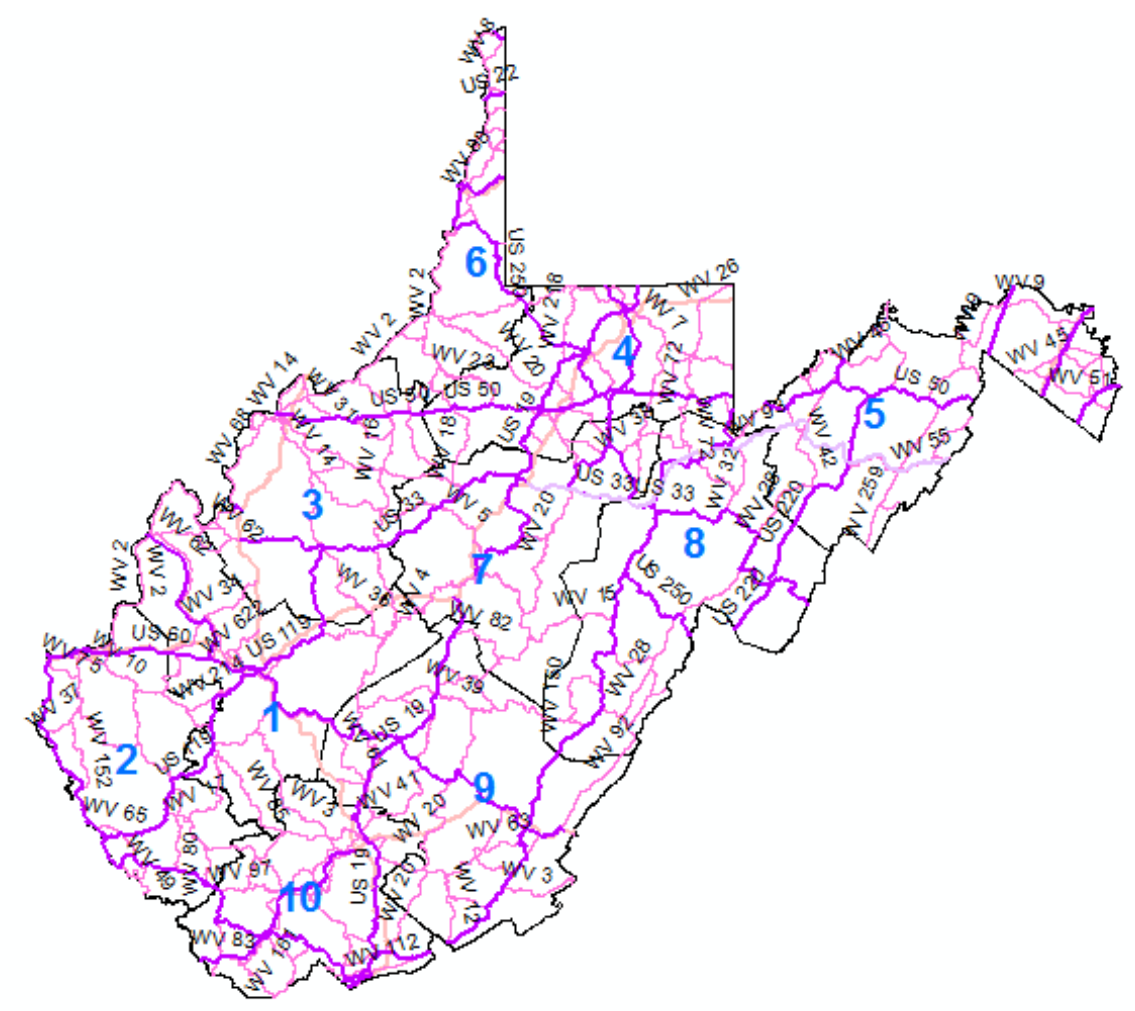

Figure 3.2 Map created in ArcGIS from 4 downloaded layers: WVDOT district outlines, State Routes, US Routes, and Interstates.

From this point, some manipulation to the map must be conducted using the tools available in ArcMap 10.0 to obtain a mapped RHRS database. The procedure is as follows:

1. Open Google Earth (or other preferred GIS source), and begin locating the sites on this program using field notes and visual aids on the map. It is easier to locate the precise location of the RHRS slope sites on Google Earth first, due to the availability of the satellite imagery to better identify the exact slopes. Placemark all RHRS slope site locations using Google Earth (Google, Inc., 2014). Figure 3.3 shows an example of this process.

2. There are two options to export the Google Earth data:

a. After confirming that the base map layer in ArcMap and Google Earth are using the same projected coordinate system, it is possible to save all placemarked places on Google Earth as a KML file and convert the file to a map layer in ArcMap. Save the layer as "RHRS Sites." Compare site location accuracy with Google Earth.

b. A slightly more tedious method is to manually create a new shapefile layer and then use the Editor toolbar to populate the layer. Entitle the point layer "RHRS Sites," and use visual aids on Google Earth to pinpoint the same exact locations on ArcMap. Add points to the layer for each site until complete.

3. Once all points are input and verified for location accuracy, open the attribute table for "RHRS Sites" and create fields for District, County, Highway, Location description, and RHRS score.

4. Edit the newly created fields with the given information for each RHRS slope site and save. 
5. Open the Properties for the RHRS Sites layer, and navigate to the Symbology tab. At this point, the ArcMap's built in Jenks Algorithm (see Section 2.6.1) will classify the ranges of RHRS scores to aid in the determination of the most hazardous slopes. Input 5 ranking classes, and use the "RHRS score" field as the Value to be ranked. The program will now rank the database of scores into 5 ranges. Select the color ramp that ranges from green to red, with red being the most hazardous RHRS score range delineation. Take note of the score ranges the Jenks algorithm developed. These ranges may change slightly with the addition or subtraction of new slope sites to the map.

6. After applying the new Symbology, the map will have an appearance to Figure 3.4 (this is just an example; a full database of RHRS scores will have many more colored dots on the map). At this point, the user can identify the most hazardous (red) slope sites using the Identify tool. The user is then able to notify the proper WVDOT district personnel to develop a plan of action for remediating the rockfall hazard for that site.

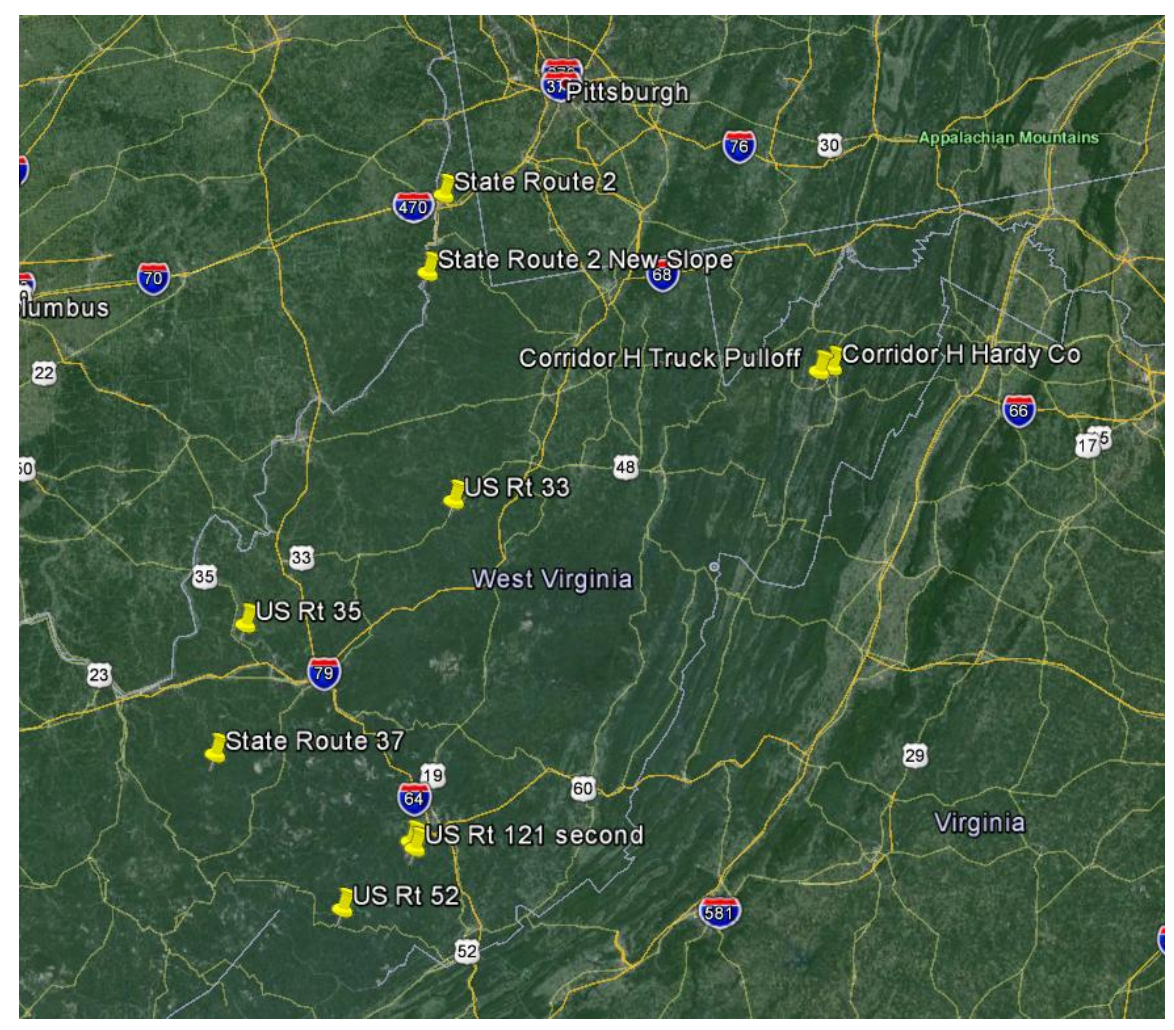

Figure 3.3 Placemarked RHRS slope sites in Google Earth. 


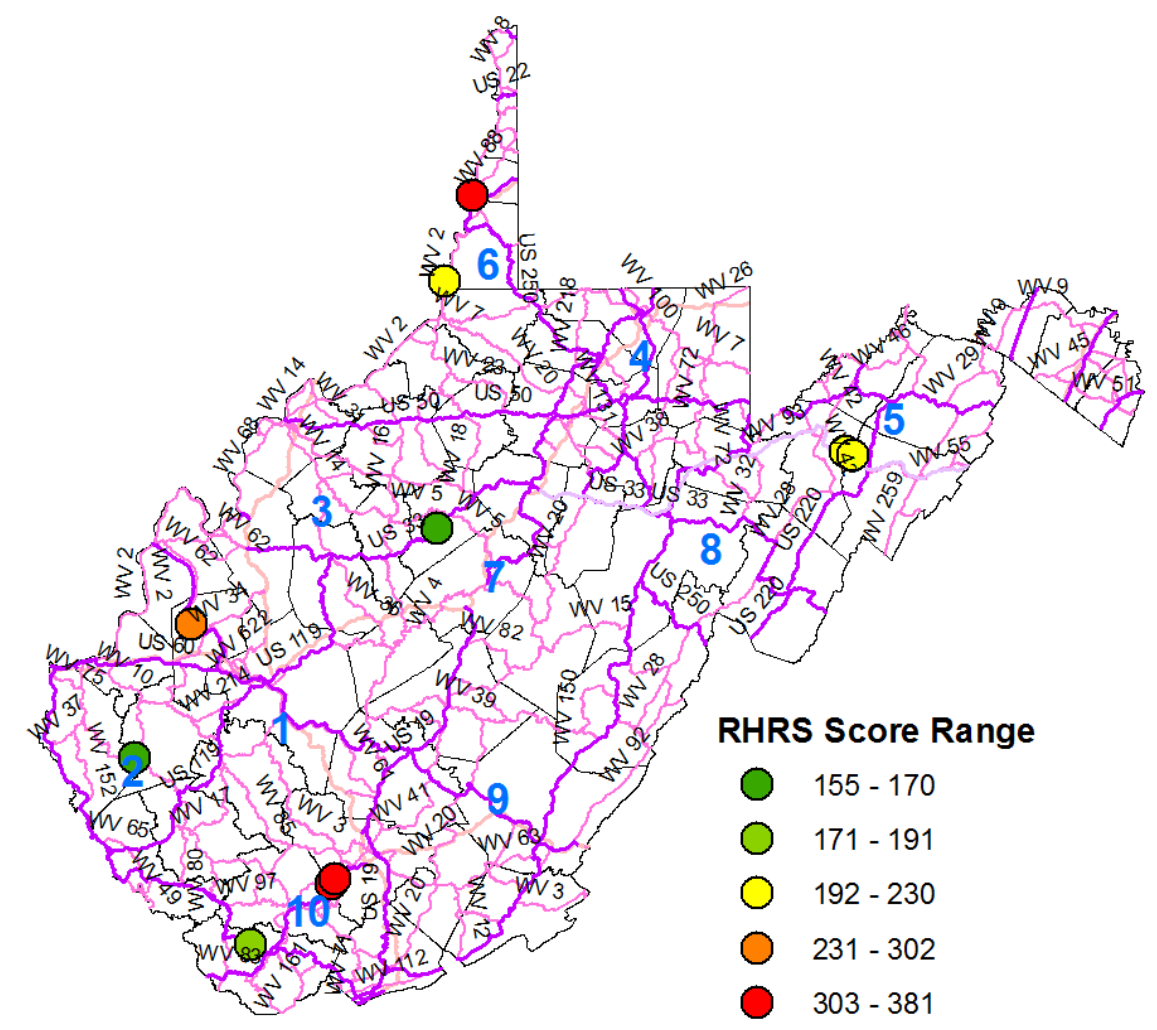

Figure 3.4 Map created in ArcGIS that displays the RHRS score ranges in a color scale and allows the user to easily detect which slope sites are the most hazardous.

The results of an RHRS case study following these steps can be found in Appendix II. It is worth noting that some of the locations pinpointed in Figure 3.3 and Figure 3.4 were added just for demonstrative purposes in this section, and the sites were not actually visited during the research. Only six sites were visited during the research, those found in Appendix II. This case study was used in the research to determine the feasibility of the RHRS re-designed for new slopes. Based on the ratings of six different slopes within West Virginia, the new slope RHRS was determined to be adequate, with additional testing needed to develop a database and reconfirm accuracy.

After determining the rock cut slopes that need to most attention (highest RHRS scores), the next step is determining what course of action to take. If the slope is still in the pre-construction phase, the use of Colorado Rockfall Simulation Program (or similar program) can aid in the determination of the proper remediation efforts to the slope design to reduce the RHRS score. If the slope has already been constructed, various on-slope or toe-of-slope rockfall mitigation practices can be selected based on availability and cost. Properly allocating resources to fix the slopes that need it most with the aid of RHRS can benefit both the Department of Transportation and roadway users. 


\section{COLORADO ROCKFALL SIMULATION PROGRAM (CRSP)}

\subsection{Version Selection Process}

Due to the limitations of the 3-Dimensional software listed in Section 2.6.1.2, including the 12foot resolution and the incapability of simulating rocks less than 100 pounds in mass, the 2Dimensional version of Colorado Rockfall Simulation Program was selected for this report. Although the 3-Dimensional version uses more realistic simulation algorithms, there is a higher need to incorporate changes in geometry less than 12 feet apart and determine the behavior of rocks less than 100 pounds when dealing with man-made cut slopes. Despite its outdated interface, CRSP-2D is still widely used in the geotechnical engineering industry, and thus is a reputable choice in accurately predicting the behavior of rockfall events.

Similar research was conducted concurrently with this research by J. Pentz using the 3Dimensional version of CRSP (Pentz, 2014). Personal communication was made with Pentz throughout this research, as some of the methods used are similar. A final comparative analysis of the two versions was not made during the timeframe of this research.

\subsection{Calibration}

In the 2-Dimensional version of CRSP, the coefficients $\left(R_{t}\right.$ and $\left.R_{n}\right)$ are very sensitive and must be precise to ensure accurate simulation results. Increasing the normal coefficient of an entire slope just 0.01 can cause increases of over $5 \%$ more rockfall reaching the roadway (depending on the geometry of the slope), a small change that causes large inaccuracies. However, as it can be seen from Table 1, the suggested ranges are very broad, and thus potentially very inaccurate. Also, these numbers were calibrated using Colorado topography and geology, which features many different characteristics when compared to the topography and geology of West Virginia. For these reasons, the values and linked descriptions to Table 1 are presumably inaccurate for this research without proper testing and recalibration. It is recommended by the developers of CRSP that all users perform a site-specific recalibration of the software to achieve the highest degree of accuracy from CRSP (Jones, 2000). After all inputs are calibrated and correctly identified for each of the slope segments, an accurate rockfall model can be run and analyzed. Table 4.1 depicts all the input parameters associated with the program, and their ability to be precisely calibrated.

Table 4.1 CRSP-2D Parameters and Possible Ranges of Values

\begin{tabular}{|l|l|l|}
\hline \multicolumn{1}{|c|}{ Parameter } & $\begin{array}{c}\text { Possible Value Range } \\
\text { (Jones, 2000) }\end{array}$ & \multicolumn{1}{|c|}{$\begin{array}{c}\text { Isolate exactly } \\
\text { ONE value after } \\
\text { calibration? }\end{array}$} \\
\hline Normal Coefficient & $0.01-1.0$ & NO \\
\hline Tangential Coefficient & $0.01-1.0$ & YES \\
\hline Surface Roughness & $0.1-5.0$ & YES, per backslope \\
\hline Rockfall Shape & $\begin{array}{l}\text { Spherical, Cylindrical, } \\
\text { Discoidal }\end{array}$ & MAYBE \\
\hline Rockfall Density (lb/ft $\left.{ }^{3}\right)$ & $>0.01$ & NO \\
\hline Rockfall Dimensions $(\mathbf{f t})$. & $>0.01$ & NO \\
\hline
\end{tabular}




\subsubsection{In-Field Calibration Technique for West Virginia}

The first step in site-specifically calibrating the Colorado Rockfall Simulation Program for use with rock cut slopes in West Virginia was to develop proper methodology for accurate field results. Both manuals (2-D and 3-D) recommend performing site-specific calibration, but suggest physically rolling rocks off a slope and monitoring each rock's behavior (velocity, bounce height, etc.) for comparison to the program simulations (Andrews, 2010). This is not feasible for most users due to lack of resources and time constraints. Thus, it is recommended that a simplified "rock count" calibration be done in place. Since falling rocks come to a stop on flat surfaces, performing a rock count at every flat location (benches, ditch bottom, roadway) and then comparing the counts at these locations to the counts in the CRSP simulations should provide proper site-specific calibration.

\subsubsection{1 "Rock Count" Calibration Method}

\section{i. Site Selection}

With respect to highway rock cut slopes in West Virginia, there are two general slope material types that will typically be encountered: hard bedrock (sandstone and limestone) and soft bedrock (shales and coal). Thus, these are the slope material types that are the focus of the calibration. The selection of a proper rock count calibration site depends on many factors:

- The user must be able to identify the general area(s) of the slope where each counted rock originated. The simplest way of achieving this is to select a slope which is homogenous in material type (slope material A) from the toe to the uppermost backslope. Then, located directly on top of this homogenous material is a measurable layer of the other slope material type (slope material B) which extends upward to the overburden. A pictorial description of this type of slope can be found in Figure 1. The reasoning for this strata configuration is that the user can count rocks consisting of slope material B on each bench, as well as the ditch and roadway, and know that they all can from the upper section of the top backslope. Then, when working with the CRSP software, the user can isolate the rockfall release zone for accurate comparison of what was observed in the field.

- NOTE: If there are no slopes available like the one listed above, an entirely homogenous slope (from toe to overburden) is acceptable. The software modeling will be more intensive (see Section 4.2.1.2).

- The slope must have a section that has experienced a statistically significant amount (>30 rocks total) of rockfall. It is important to note at this point that a countable rock is any rock greater than 6 inches in diameter that has dislodged from a backslope and is within the "rock count" section. There is no lower limit to the length of section (parallel to roadway), but from experience, a section of approximately 200 feet is desirable. The section must be continuously homogenous throughout its entire length. The number of benches, total height of slope, and strata configuration must not change within the section. A strata layer that tapers or dissipates within the rock count section will not be properly modeled in CRSP-2D

- The slope must be newly constructed. Slopes more than five years old will most likely have inaccessible benches due to either an excess of fallen rocks and debris or large vegetation. However, slopes that are newer than one year old may not have experienced enough rockfall to count (see previous bullet). Newer slopes are also more desirable as 
the backslopes tend to be smoother, thus making the surface roughness parameter (S) easier to estimate.

- As safety is always a top concern, slopes must be completely accessible. There must be a safe way for the calibration technician(s) to reach all benches without putting their safety at risk.

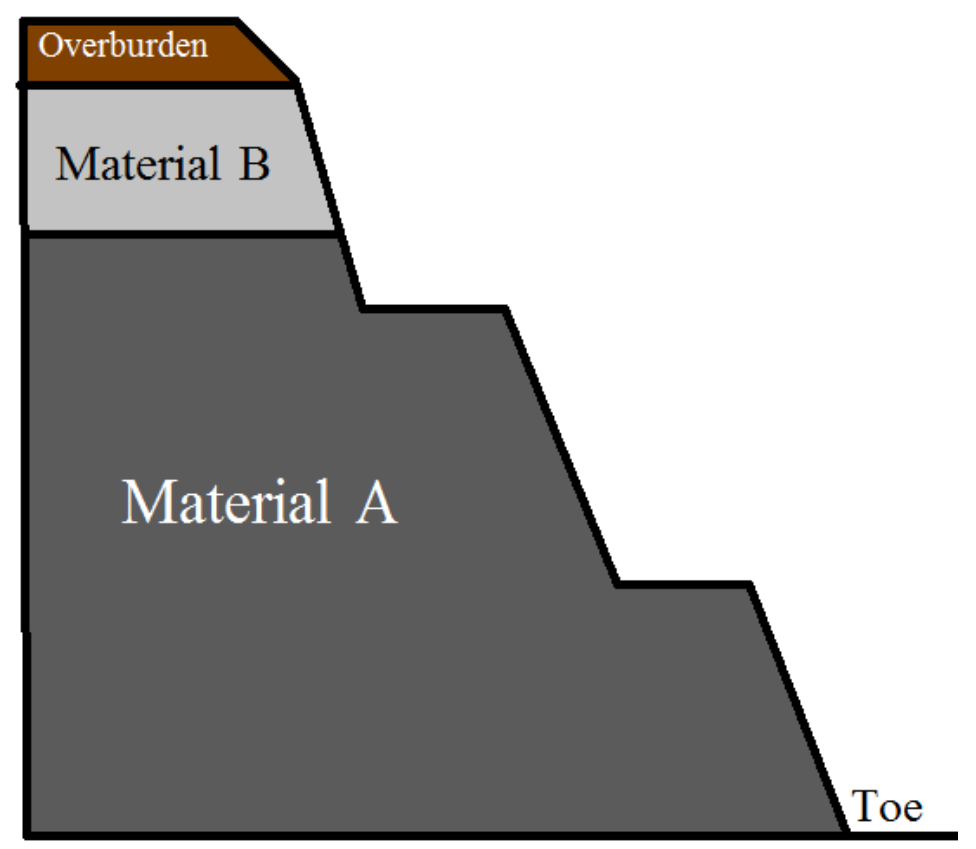

Figure 4.1 Visual Representation of ideal slope type for calibration site

Interpreting geologic maps of West Virginia, along with gathering information from WVDOT and highway construction companies should provide enough information to select the proper sites for CRSP calibration. The sites do not need to be along the same stretch of roadway, but should be conducted within the borders of West Virginia to ensure similar topography.

\section{ii. Field Calibration}

Upon selection of sites, the in-field portion of site-specific calibration can begin. Materials needed to conduct the rock count include a retractable tape measure, a larger surveyor's tape measure, a clinometer for measuring angles, the proper safety equipment (vests, safety cones, etc.), and the blank forms shown in Tables 4.2 and 4.3 to be used in data collection on the slopes. Information that must be collected for each site includes the number of CRSP "cells," the geometry of the slope, and the estimated CRSP parameters for each cell, along with a "rock count" on each cell that is not a backslope. The rock count is categorized by rock size, as seen in Table 4.3. A more in-depth version of these tables can be found in the Field Workbook entitled: "CRSP Field Calibration Workbook," found in Appendix A. 
Table 4.2 Cell Identification Table to be used with CRSP Field Calibration

\begin{tabular}{|c|c|c|c|c|c|c|c|c|}
\hline Cell \# & $\mathbf{l}$ & $\mathbf{2}$ & $\mathbf{3}$ & $\mathbf{4}$ & $\mathbf{5}$ & $\mathbf{6}$ & $\mathbf{7}$ & $\mathbf{8}$ \\
\hline $\begin{array}{c}\text { Cell location and type } \\
\text { (Bench, backslope...) }\end{array}$ & Roadway & & & & & & & \\
\hline $\begin{array}{c}\text { Tangential Length } \\
\text { (ft.) and Angle }\end{array}$ & $/ 0 \%$ & $/$ & $/$ & $/$ & $/$ & $/$ & $/$ & $/$ \\
\hline $\begin{array}{c}\text { Estimated Surface } \\
\text { Roughness }\end{array}$ & 0.0 & & & & & & & \\
\hline $\begin{array}{c}\text { Vegetative Cover (\%) } \\
\text { Material Type }\end{array}$ & Pavement & & & & & & & \\
\hline $\begin{array}{c}\text { Estimated Tangential } \\
\text { Coefficient }\end{array}$ & & & & & & & & \\
\hline $\begin{array}{c}\text { Estimated Normal } \\
\text { Coefficient RANGE }\end{array}$ & & & & & & & & \\
\hline $\begin{array}{c}\text { Estimated Hardness } \\
\text { Coefficient RANGE }\end{array}$ & & & & & & & & \\
\hline
\end{tabular}

Table 4.3 Rockfall Tally Table to be used with CRSP Field Calibration

\begin{tabular}{|c|c|c|c|c|c|c|c|}
\hline \multirow{2}{*}{$\begin{array}{c}\text { Cell \# } \\
\text { (benches } \\
\text { only) }\end{array}$} & \multirow{2}{*}{$\begin{array}{c}\text { Material } \\
\text { Type }\end{array}$} & \multicolumn{6}{|c|}{ Rock Diameter (ft.) } \\
\hline & & $<1$ & $\begin{array}{l}1- \\
1.9\end{array}$ & $\begin{array}{l}2- \\
2.9\end{array}$ & $\begin{array}{l}3- \\
3.9\end{array}$ & $\begin{array}{l}4- \\
4.9\end{array}$ & $\geq 5$ \\
\hline \multicolumn{8}{|l|}{1} \\
\hline & & & & & & & \\
\hline \multicolumn{8}{|l|}{2} \\
\hline & & & & & & & \\
\hline \multicolumn{8}{|l|}{3} \\
\hline & & & & & & & \\
\hline \multicolumn{8}{|l|}{4} \\
\hline & & & & & & & \\
\hline \multicolumn{8}{|l|}{5} \\
\hline & & & & & & & \\
\hline \multicolumn{8}{|l|}{6} \\
\hline & & & & & & & \\
\hline \multicolumn{8}{|l|}{7} \\
\hline & & & & & & & \\
\hline \multicolumn{8}{|l|}{8} \\
\hline & & & & & & & \\
\hline
\end{tabular}

Assess the site and use the surveyor's tape to get an accurate measurement of the selected section of the slope that meets the requirements listed above. Place markers at the ends of the sections that are visible from each of the benches. Starting with the nearest roadway lane, begin filling out the first data collection table (Table 4.2). There are tangential, normal, and hardness coefficient description tables in the end of the Field Workbook packet to help the technician select initial ranges based on material identification and visual aids. Surface roughness should 
be estimated (or physically measured if possible) by the method described in the Field Workbook packet for each cell.

After finishing a row of the Cell Identification Table for a given cell, the technician(s) should move to the second table (Table 4.3), which is designed to help tally a rock count. Starting at one end of the calibration section, use the retractable tape measure to find the diameter of each fallen rock within the cell. Record whether the rock is either hard or soft bedrock (see Definitions section), and provide a tally mark in the proper box. Notice that there is a designated box for every foot increase in diameter. This will make the program calibration easier by categorizing rock sizes. There should be a tally mark for each rock appearing greater than 6 inches in diameter within the calibration section. Upon reaching the other end of the section within the first cell, the technician(s) should move to the next cell, and start over with the Cell Identification Table. This process should be repeated until completion of the final backslope.

The field portion of site-specific CRSP calibration is complete when the following criteria have been fulfilled (reference Figure 1):

- Completed data tables for at least one section of rock cut slope with homogenous hard bedrock strata layer(s) from toe of slope to highest backslope, followed by homogenous soft bedrock strata layer(s) from top of hard bedrock section to bottom of overburden.

- Completed data tables for at least one section of rock cut slope with homogenous soft bedrock strata layer(s) from toe of slope to highest backslope, followed by homogenous hard bedrock strata layer(s) from top of soft bedrock section to bottom of overburden.

\subsubsection{Alternate Field Calibration Method}

Alternatively, if there are no available slope sections similar to that of Figure 4.1, slope sections that are completely homogenous of one material type (either hard bedrock or soft bedrock) may be used. For this method, technician(s) follow the same procedure as previously listed, but only need to account for one fallen rock type in the Rock Tally Table (Table 4.3). The field portion of this CRSP calibration method is complete when completed data tables for at least one section of completely homogenous hard bedrock has been completed, as well as data tables for at least one section of completely homogenous hard bedrock.

\subsubsection{CRSP Version 4.0 Program Calibration}

After completing the in-field portion of the calibration, the collected data must be reduced. Organize the data in the following ways:

- Complete the Field Workbook packet by recording the following information for each section: total number of benches in section, total height of section, estimated starting location (in height from toe) of majority of rockfall events, and most common fallen rock shapes observed

- Construct slope profiles from the measured widths, heights, and angles of the slope sections. Organize as $(\mathrm{x}, \mathrm{y})$ coordinates

- Sum the "rock count" tallies, including the amount of fallen rocks for each material type and each size designation in each cell, the total amount of fallen rocks counted, and the average size of the fallen rocks counted

Begin by selecting Material A as the initial surface material to calibrate. While there are many un-calibrated material types (hard bedrock, soft bedrock, firm soil, and pavement), each with an unknown normal and tangential coefficient, it is important to remember that the goal of sitespecific calibration is to determine the exact value (or a small range of values) for the normal 
coefficient for both hard bedrock and soft bedrock only. The other parameter values can be assumed for the following reasons:

- Tangential Coefficient $\left(\mathrm{R}_{\mathrm{t}}\right)$

○ Pavement: Should have a value approaching 1.0. Very small range of possible values.

○ Firm soil: Soil is densely compacted, so will tend to be in higher end of given range. Rock has already left slope by the time it reaches soil, so minimal affect to its overall travel.

O Hard and soft bedrock: $R_{t}$ is not nearly as sensitive as $R_{n}$ (little change in results from small changes in value). Range for $R_{t}$ in bedrock is much smaller than range for $\mathrm{R}_{\mathrm{n}}$.

- Normal Coefficient $\left(\mathrm{R}_{\mathrm{n}}\right)$

○ Pavement: Should have a value approaching 1.0. If a rock has reached the pavement, it has already become a hazard to roadway users.

○ Firm soil: Very small range of possible values, regardless of compaction quality.

Open CRSP-2D, and begin performing calibration simulations using the following procedure to find the most accurate parameter values:

1. Open the program interface, create a new file, and input the general file specifications (total number of cells, locations of analysis points, initial x-y coordinates). All of this information can be taken directly from the field workbook data. In the "Analysis Points" fields, input the x-coordinates at the front end of each bench. If there is still a blank analysis point field, input the edge of the roadway. From these inputs, the user can see statistics on how many fallen rocks stop on each of the benches, which can then be matched to the observed "rocks counted" data from the field.

2. The next requested inputs are the three parameters $\left(S, R_{n}, R_{t}\right)$ along with the $x$ and $y$ coordinates for each cell. Surface roughness values can be taken directly from the Field Workbook data. Referencing the first table in Figure 2, begin at the roadway by inputting the beginning and ending $(x, y)$ coordinates. Each material type will have different $R_{t}$ and $R_{n}$ values, but as mentioned, the focus of this calibration is only to find the $R_{n}$ values for hard bedrock and soft bedrock. Next, input the coordinates and estimated coefficient values for the firm soil ditch after finishing the roadway cells. The focus of the calibration will be the two materials within the slope, Materials A and B (see Figure 4.1), and each will have different $R_{n}$ values upon final calibration. For each slope, Material $A$ is the slope material that will have its normal coefficient calibrated. Select "average" $R_{n}$ values for the cell(s) containing Material B and do not change these numbers between trials. Assume a value for $\mathrm{R}_{\mathrm{t}}$ for each cell based on the provided ranges located in the Field Workbook and the observed condition of the cell in the field. It is important to keep a constant value for $R_{t}$ throughout the initial program calibration, as $R_{n}$ will be the only independent variable. Then, select the $R_{n}$ value for each cell consisting of Material $A$ at the lowest end of the suggested range in the Field Workbook. Repeat this process for each cell until the slope profile is complete.

3. The program then requests the rock simulation specifications, including the amount, density, and shape of simulated falling rocks, as well as the initial cell where the rocks are falling from. Start the calibration process by focusing on the projection of the smaller 
falling rocks from Material $\mathrm{B}$, and input the total number of counted rocks less than $1 \mathrm{ft}$. in diameter from the Field Workbook data into the "Total Number of Rocks to be Simulated" field. The rockfall density is the density of Material B. Find this density value from published literature (Zhao, 2010). The shape of the falling rocks should also be taken from the recorded Field Workbook data as the rockfall shape that was most common. If it is unsure what the most common rockfall shape was, use "spherical" until the $R_{n}$ value nears calibration, then experiment with other shapes for higher accuracy if necessary.

4. The final step before simulation is to enter the dimensions of the fallen rock. Since the initial focus is the smaller rocks ( $<1 \mathrm{ft}$. diameter), input the observed average value from the field in this range (somewhere between $0.75 \mathrm{ft}$. and $0.9 \mathrm{ft}$.).

5. The simulation will now run.

6. Refer to the Results section when interpreting the simulation results. If the initial $R_{n}$ input does not provide simulation results that resemble the field data, return to Step 2, and increase the $R_{n}$ value by 0.01 (staying within the initial range) for Material A. Continue this process until the $\mathrm{R}_{\mathrm{n}}$ value for Material A provides simulation results that match what was observed in the field. At this time, it is acceptable to tweak the value for $\mathrm{R}_{\mathrm{t}}$ for Material A to see if a more accurate calibration can be produced.

7. Test the calibrated $R_{n}$ value on rockfall ranging between $1.0 \mathrm{ft}$. and $1.9 \mathrm{ft}$. using the same method listed in Steps 3 and 4. Adjust Material A's normal and tangential coefficient values as necessary. Continue this process for all recorded rockfall size ranges.

8. Material A is now temporarily calibrated for normal coefficient. If Material A was soft bedrock, repeat Steps 1 through 7 with Material A being hard bedrock (or vice versa).

9. Input the updated values for Material B in both CRSP calibration models and make any final adjustments to $R_{n}$ in an iterative process between the two slope material types.

Normal coefficient (and in the process, tangential coefficient) for CRSP is now specifically calibrated for hard bedrock and soft bedrock for West Virginia highway rock cut slopes. An example of a completed CRSP-2D site-specific calibration can be found in Appendix B.

\subsubsection{Interpreting CRSP Version 4.0 Results}

The two-dimensional version of CRSP provides many useful diagrams, statistics, and graphs for each simulation trial. After accurately inputting all the parameters and clicking the "Begin Rockfall Simulation" button, the initial Results window shows the slope profile with a visual representation of the paths each falling rock took down the two-dimensional slope (see Figure 4.2). 


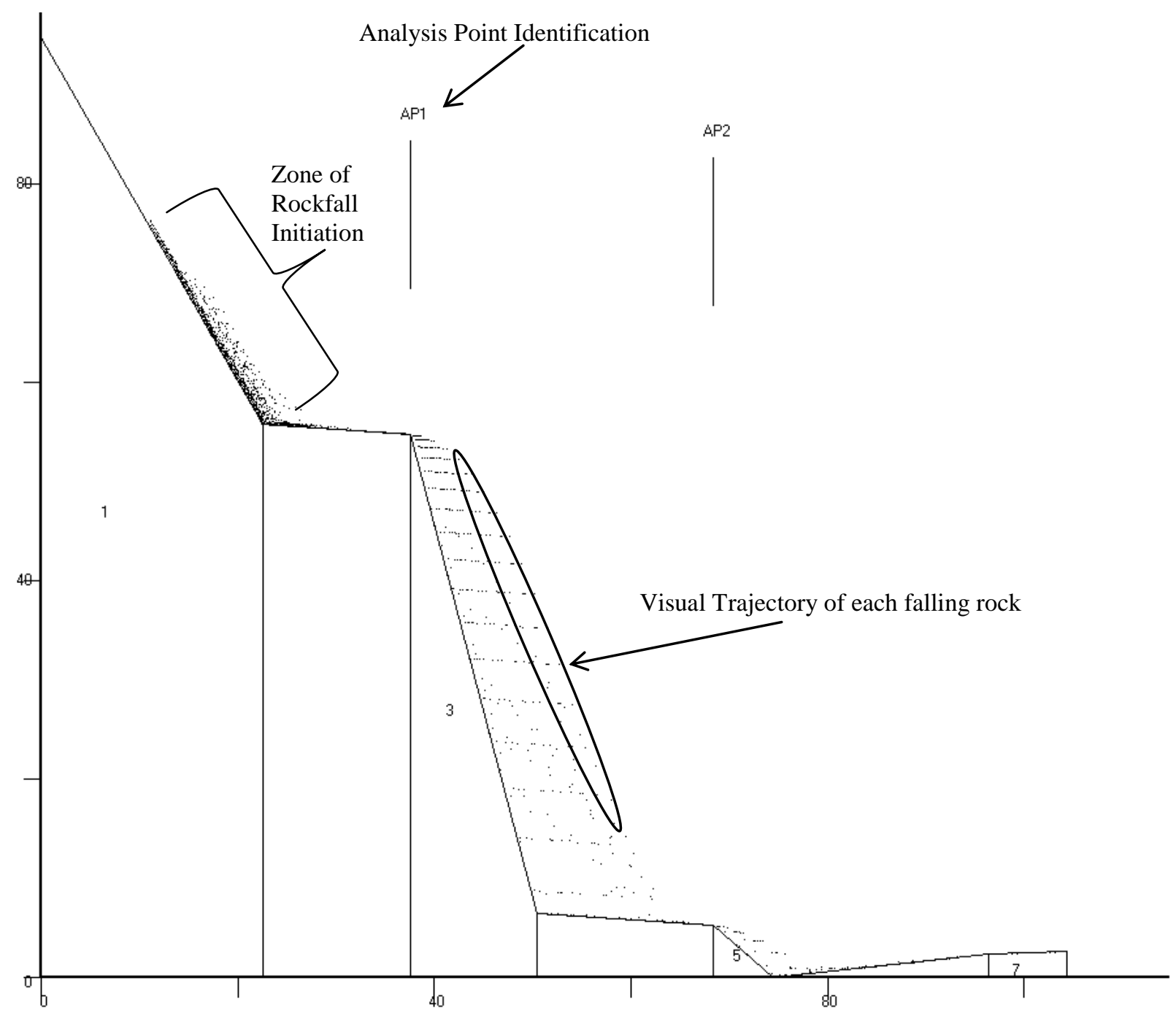

Figure 4.2 CRSP 2-D Slope Profile showing simulation trial results

The next few Results tabs show compiled data for each rock passing the user-input analysis point(s). Statistics shown include the amount of rocks that passed the point, average and maximum velocity, average and maximum bounce height, and average and maximum kinetic energy (Figure 4.3). There is also a probability analysis for each analysis point (Figure 4.4) showing the probability that each rock passing that point has a certain velocity, energy, and bounce height. 


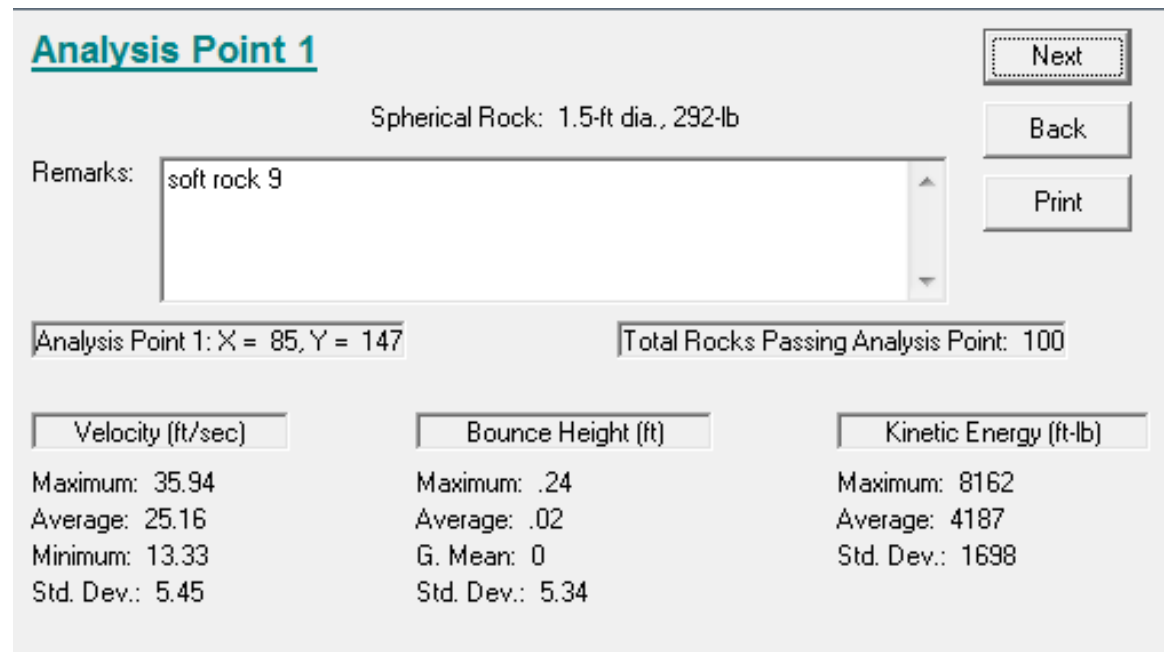

Figure 4.3 CRSP Analysis Point Statistics

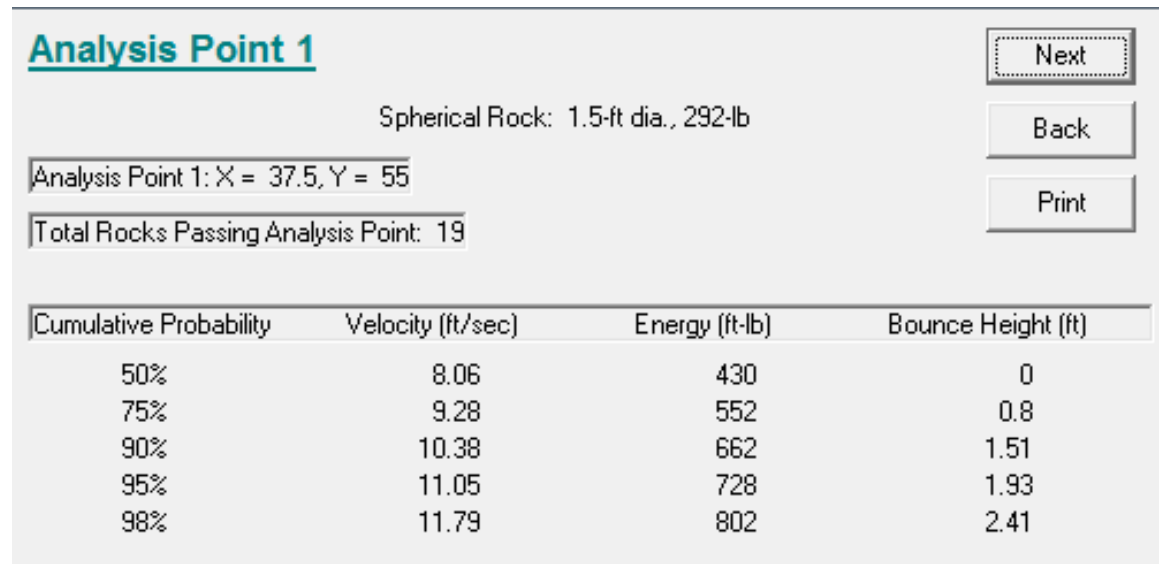

Figure 4.4 Probability analysis for each rock at "Analysis Point 1" in a CRSP simulation trial

Following these statistics are various histograms showing the frequencies of simulated rocks having specific velocities, bounce heights, or kinetic energies at each analysis point. Following the histograms are line graphs showing the maximum velocities (Figure 4.5) and bounce heights for the fallen rocks as they traveled down the slope profile. The final results tabs show individual statistics for each simulated fallen rock in tabular form. 


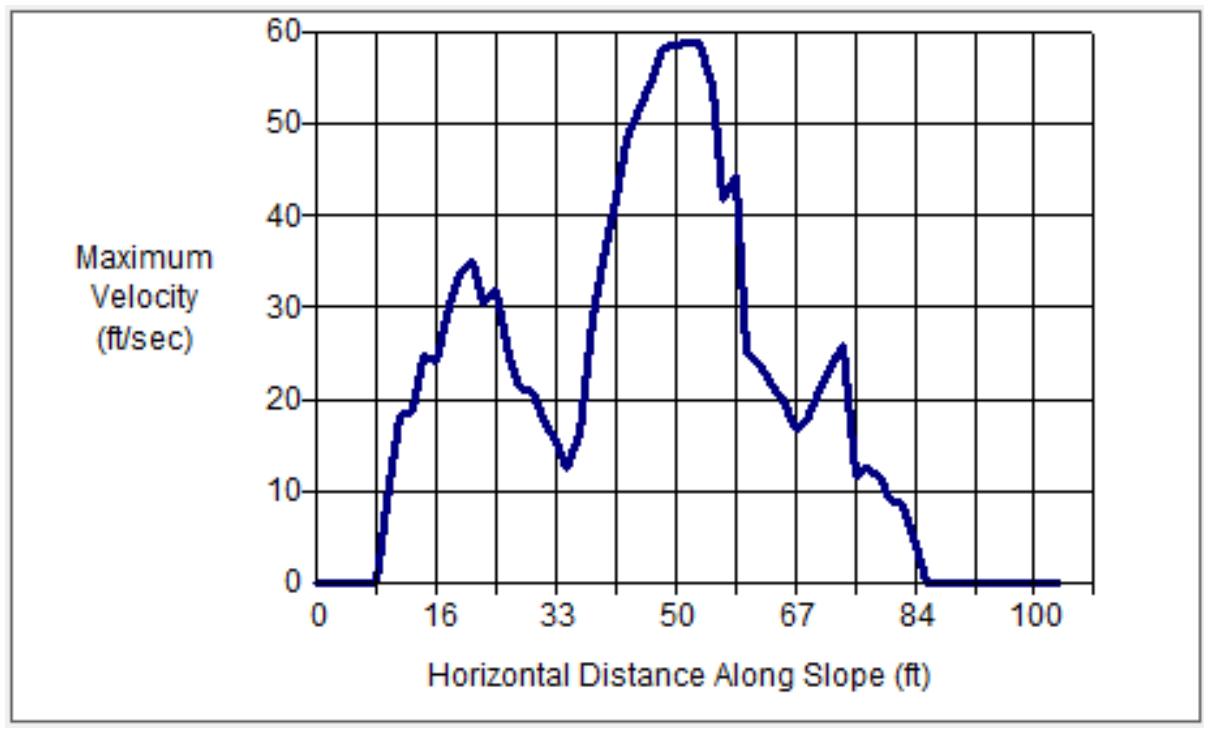

Figure 4.5 Line graph output by CRSP-2D depicting the maximum velocity of the fallen rocks as they travelled down the slope profile during simulation

\subsubsection{CRSP-2D Calibration Results for West Virginia}

\subsubsection{Soft Bedrock}

A three-year-old highway rock cut slope on US Route 121 near Sophia, WV was selected as the initial calibration site for soft bedrock. The slope section (Figure 4.6) had a vertical height of 108 feet, a total of three geotechnical benches, and an adequate rockfall history. The method described in Section 4.3.1.1, or the "Rock Count" method, was used for this calibration process. Tables 4.4-4.6 show the raw data collected from the field visit to this site, while Figure 4.5 displays the slope profile modeled in CRSP-2D.

Table 4.4 General Information collected from Soft Bedrock CRSP-2D Calibration Site 1

\begin{tabular}{|l|c|}
\hline 1. Location of Section on Slope: & Second Cut of unpaved section. Left side. \\
\hline 2. Section Length Parallel to Roadway: & Approximately 180 feet \\
\hline 3. Vertical Section Height: & 3 \\
\hline 4. Total Number of Benches: & \multicolumn{1}{|c|}{10} \\
\hline $\begin{array}{l}\text { 5. Estimated Starting Location of Most } \\
\text { Rockfall Events: }\end{array}$ & Top of Backslope 3, where hard bedrock section is located \\
\hline $\begin{array}{l}\text { 6. Total number of CRSP “cells" needed } \\
\text { for this section: }\end{array}$ & 142 \\
\hline $\begin{array}{l}\text { 7. Total counted fallen rocks in section: } \\
\text { 8. Average diameter of fallen rocks in } \\
\text { section: }\end{array}$ & 1.50 feet \\
\hline
\end{tabular}


Table 4.5 Completed Cell Identification Table for Soft Bedrock Calibration Site 1

\begin{tabular}{|c|c|c|c|c|c|c|c|c|c|c|}
\hline Cell \# & 10 & 9 & 8 & 7 & 6 & 5 & 4 & 3 & 2 & 1 \\
\hline $\begin{array}{c}\text { Cell } \\
\text { Location }\end{array}$ & Road & $\begin{array}{c}\text { Drainage } \\
\text { Ditch }\end{array}$ & $\begin{array}{c}\text { Backslope } \\
1\end{array}$ & Bench 1 & $\begin{array}{c}\text { Backslope } \\
2\end{array}$ & Bench 2 & $\begin{array}{c}\text { Backslope } \\
3\end{array}$ & Bench 3 & $\begin{array}{c}\text { Backslope } \\
4.1\end{array}$ & $\begin{array}{c}\text { Backslope } \\
4.2\end{array}$ \\
\hline $\begin{array}{c}\text { Height/ } \\
\text { Width (ft.) }\end{array}$ & $\mathrm{n} / \mathrm{a}$ & 25 & 13 & 25 & 49 & 32 & 67 & 20 & 30 & 25 \\
\hline $\begin{array}{c}\text { Angle } \\
\text { (Backslope } \\
\text { only) }\end{array}$ & - & $6^{\circ}$ & $40^{\circ}$ & - & $75^{\circ}$ & - & $80^{\circ}$ & - & $75^{\circ}$ & $75^{\circ}$ \\
\hline $\begin{array}{c}\text { Estimated } \\
\text { Surface } \\
\text { Roughness }\end{array}$ & 0.0 & 0.0 & 0.2 & 0.0 & 0.5 & 0.0 & 0.4 & 0.0 & 1.5 & 0.75 \\
\hline $\begin{array}{l}\text { Vegetative } \\
\text { Cover }(\%)\end{array}$ & 0 & 100 & 100 & 100 & 0 & 50 & 5 & 5 & 0 & 5 \\
\hline $\begin{array}{c}\text { Material } \\
\text { Type in } \\
\text { Cell }\end{array}$ & Asphalt & Firm Soil & Firm Soil & $\begin{array}{c}\text { Soft } \\
\text { Bedrock }\end{array}$ & $\begin{array}{c}\text { Soft } \\
\text { Bedrock }\end{array}$ & $\begin{array}{c}\text { Soft } \\
\text { Bedrock }\end{array}$ & $\begin{array}{c}\text { Soft } \\
\text { Bedrock }\end{array}$ & $\begin{array}{c}\text { Soft } \\
\text { Bedrock }\end{array}$ & $\begin{array}{c}\text { Soft } \\
\text { Bedrock }\end{array}$ & $\begin{array}{c}\text { Hard } \\
\text { Bedrock }\end{array}$ \\
\hline $\begin{array}{c}\text { Initial } \\
\text { CRSP R }_{\text {n }} \\
\text { Range }\end{array}$ & $\begin{array}{c}0.6- \\
1.0\end{array}$ & $\begin{array}{c}0.12- \\
0.20\end{array}$ & $\begin{array}{c}0.12- \\
0.20\end{array}$ & $\begin{array}{c}0.15- \\
0.30\end{array}$ & $\begin{array}{c}0.15- \\
0.30\end{array}$ & $\begin{array}{c}0.15- \\
0.30\end{array}$ & $\begin{array}{c}0.15- \\
0.30\end{array}$ & $\begin{array}{c}0.15- \\
0.30\end{array}$ & $\begin{array}{c}0.15- \\
0.30\end{array}$ & $\begin{array}{c}0.20- \\
0.60\end{array}$ \\
\hline
\end{tabular}

Table 4.6 Completed Rockfall Tally Table for Soft Bedrock Calibration Site 1

\begin{tabular}{|c|c|c|c|c|c|c|}
\hline \multirow{2}{*}{ Cell \# } & \multicolumn{6}{|c|}{ Rock Diameter (ft.) } \\
\cline { 2 - 7 } & $<\mathbf{1 . 0}$ & $\mathbf{1 . 0}-\mathbf{1 . 9}$ & $\mathbf{2 . 0}-\mathbf{2 . 9}$ & $\mathbf{3 . 0}-\mathbf{3 . 9}$ & $\mathbf{4 . 0}-\mathbf{4 . 9}$ & $>\mathbf{5 . 0}$ \\
\hline $\mathbf{1 0}$ & 0 & 0 & 0 & 0 & 0 & 0 \\
\hline $\mathbf{9}$ & 1 & 2 & 0 & 0 & 0 & 0 \\
\hline $\mathbf{7}$ & 5 & 5 & 1 & 1 & 0 & 1 \\
\hline $\mathbf{5}$ & 12 & 22 & 9 & 1 & 0 & 1 \\
\hline $\mathbf{3}$ & 39 & 20 & 13 & 4 & 3 & 2 \\
\hline Totals: & $\mathbf{5 7}$ & $\mathbf{4 9}$ & $\mathbf{2 3}$ & $\mathbf{6}$ & $\mathbf{3}$ & $\mathbf{4}$ \\
\hline
\end{tabular}




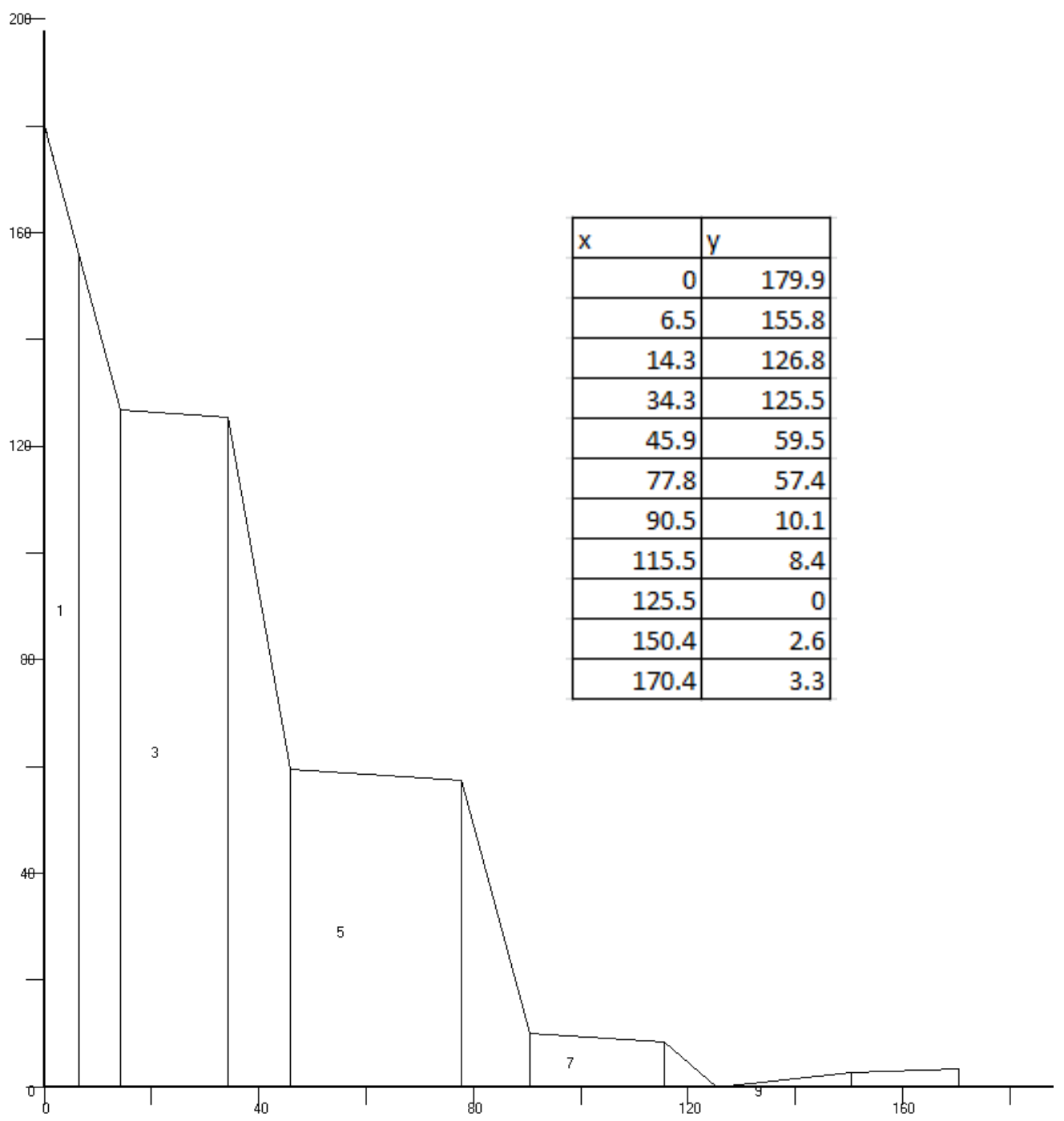

Figure 4.6 Soft Bedrock Calibration Site 1 Slope Profile created in CRSP-2D

Some aspects of slope geometry were assumed from WV DD-403, as they were not easily measureable at the field site. These include the bench angles (15H:1V) and the roadway grade $\left(3.8^{\circ}\right)$.

Upon completion of the slope profile, calibration trials were conducted. The initial assumed values for the soft bedrock were: $\mathrm{R}_{\mathrm{t}}=0.90, \mathrm{R}_{\mathrm{n}}=0.40$, and rockfall shape $=$ spherical. The calibration trials were conducted under the assumption of constant values for hard bedrock (the falling rock) of $R_{t}=0.95$ and $R_{n}=0.5$. Additionally, it was found in the field visit that fallen rocks between the sizes of 1.0 foot and 1.9 feet had an average size of approximately 1.25 feet in diameter, thus this value was selected as the constant rockfall size in the calibration trials. From this point, trials were conducted in the manner shown in Table 4.7. These numbers were then reconfirmed with a falling rock dimension of 2.3 feet (the average observed field rockfall diameter of rocks between 2.0 and 2.9 feet in diameter) in Table 4.8 . 
Table 4.7 Trial-and-Error CRSP-2D Calibration for Soft Bedrock with Diameter of 1.25 Feet

\begin{tabular}{|c|c|c|c|c|c|c|c|}
\hline \multirow{2}{*}{$\begin{array}{c}\text { Calibration } \\
\text { Run \# }\end{array}$} & \multicolumn{2}{|c|}{$\begin{array}{c}\text { Soft Bedrock } \\
\text { Parameters }\end{array}$} & \multirow{2}{*}{$\begin{array}{c}\text { Rockfall } \\
\text { Shape }\end{array}$} & \multicolumn{4}{|c|}{ Rock Accumulation Tally } \\
\cline { 6 - 8 } & $\mathbf{R}_{\mathbf{n}}$ & $\mathbf{R}_{\mathbf{t}}$ & & Bench 3 & Bench 2 & Bench 1 & Ditch/Road \\
\cline { 6 - 8 } Field Counts & - & - & - & $\mathbf{2 0}$ & $\mathbf{2 2}$ & $\mathbf{5}$ & $\mathbf{2}$ \\
\hline $\mathbf{1}$ & 0.40 & 0.90 & spherical & 41 & 5 & 1 & 2 \\
\hline $\mathbf{2}$ & 0.30 & 0.90 & spherical & 39 & 7 & 2 & 1 \\
\hline $\mathbf{3}$ & 0.30 & 0.90 & cylindrical & 31 & 13 & 1 & 4 \\
\hline $\mathbf{4}$ & 0.25 & 0.90 & cylindrical & 32 & 15 & 2 & 0 \\
\hline $\mathbf{5}$ & 0.25 & 0.91 & cylindrical & 26 & 19 & 3 & 1 \\
\hline $\mathbf{6}$ & 0.25 & 0.91 & discoidal & 22 & 23 & 4 & 0 \\
\hline $\mathbf{7}$ & 0.25 & 0.92 & discoidal & 26 & 17 & 4 & 2 \\
\hline $\mathbf{8}$ & 0.26 & 0.92 & discoidal & 26 & 20 & 3 & 0 \\
\hline $\mathbf{9}$ & 0.27 & 0.90 & discoidal & 27 & 19 & 3 & 0 \\
\hline $\mathbf{1 0}$ & 0.27 & 0.90 & cylindrical & 27 & 20 & 1 & 1 \\
\hline $\mathbf{1 1}$ & 0.25 & 0.91 & cylindrical & 30 & 17 & 1 & 1 \\
\hline
\end{tabular}

Table 4.8 Trial-and-Error CRSP-2D Calibration for Soft Bedrock with Diameter of 2.30 Feet

\begin{tabular}{|c|c|c|c|c|c|c|c|}
\hline \multirow{2}{*}{$\begin{array}{c}\text { Calibration } \\
\text { Run \# }\end{array}$} & \multicolumn{2}{|c|}{$\begin{array}{c}\text { Soft Bedrock } \\
\text { Parameters }\end{array}$} & \multirow{2}{*}{$\begin{array}{c}\text { Rockfall } \\
\text { Shape }\end{array}$} & \multicolumn{4}{|c|}{ Rock Accumulation Tally } \\
\cline { 2 - 5 } & $\mathbf{R}_{\mathbf{n}}$ & $\mathbf{R}_{\mathbf{t}}$ & & Bench 3 & Bench 2 & Bench 1 & Ditch/Road \\
\cline { 6 - 8 } Field Counts & - & - & - & $\mathbf{1 3}$ & $\mathbf{9}$ & $\mathbf{1}$ & $\mathbf{0}$ \\
\hline $\mathbf{1}$ & 0.25 & 0.92 & discoidal & 15 & 4 & 3 & 1 \\
\hline $\mathbf{2}$ & 0.25 & 0.92 & cylindrical & 16 & 6 & 1 & 0 \\
\hline $\mathbf{3}$ & 0.27 & 0.90 & discoidal & 15 & 6 & 2 & 0 \\
\hline $\mathbf{4}$ & 0.27 & 0.90 & cylindrical & 15 & 7 & 1 & 0 \\
\hline
\end{tabular}


From Table 4.7, small ranges of both $\mathrm{R}_{\mathrm{n}}$ and $\mathrm{R}_{\mathrm{t}}$ produce very accurate results in comparison to field conditions. These values were then tested with another size of falling rocks in Table 4.8, with similar accurate results. An additional slope was also calibrated, and produced identical results (see Appendix IV). Thus, a confirmed final calibrated range of values for both normal and tangential coefficients for soft bedrock is shown in Table 4.9. Notice the high precision of the coefficient ranges for West Virginia calibration compared to the given ranges from the Colorado calibration. It previously mentioned, it is necessary to determine precise values for these coefficients, as slight changes can drastically alter the simulation results. Thus, the broad Colorado calibration suggested ranges are unusable without additional information or calibration.

Table 4.9 Calibrated CRSP-2D Coefficient Values for Soft Bedrock in West
\begin{tabular}{|c|c|c|}
\hline Virginia & $\begin{array}{c}\text { West Virginia } \\
\text { Calibration Results }\end{array}$ & $\begin{array}{c}\text { Suggested Ranges from } \\
\text { Colorado Calibration }\end{array}$ \\
\hline Normal Coefficient, $\mathbf{R}_{\mathbf{n}}$ & $0.25-0.27$ & $0.15-0.30$ \\
\hline Tangential Coefficient, $\mathbf{R}_{\mathbf{t}}$ & $0.90-0.93$ & $0.75-0.95$ \\
\hline Rockfall Shape & Cylindrical or Discoidal & - \\
\hline
\end{tabular}

\subsubsection{Hard Bedrock}

A six-year-old highway rock cut slope on US Route 48 near Moorefield, WV was selected as the initial calibration site for hard bedrock. The slope section (Figure 4.7) had a vertical height of 95 feet, a total of two geotechnical benches, and an adequate rockfall history. The method described in Section 4.3.1.2, or the Alternate field calibration method, was used for this calibration process. Tables $4.10-4.12$ show the raw data collected from the field visit to this site, while Figure 4.6 displays the slope profile modeled in CRSP-2D. 
Table 4.10 General Information Collected from Hard Bedrock CRSP-2D Calibration Site 1

\begin{tabular}{|c|c|}
\hline 1. Location of Section on Slope: & $\begin{array}{c}\text { Closest Inspected Slope to Moorefield Exit, } \\
\text { Eastbound lane }\end{array}$ \\
\hline 2. Section Length Parallel to Roadway: & 200 feet \\
\hline 3. Vertical Section Height: & 94.75 feet \\
\hline 4. Total Number of Benches: & 2 \\
\hline $\begin{array}{c}\text { 5. Estimated Starting Location of Most } \\
\text { Rockfall Events: }\end{array}$ & Both backslopes (primarily localized events) \\
\hline $\begin{array}{c}\text { 6. Total number of CRSP “cells" needed } \\
\text { for this section: }\end{array}$ & 7 \\
\hline 7. Total counted fallen rocks in section: & 139 \\
\hline 8. Average diameter of fallen rocks in \\
section:
\end{tabular}

Table 4.11 Completed Cell Identification Table for Hard Bedrock Calibration Site 1

\begin{tabular}{|c|c|c|c|c|c|c|c|}
\hline Cell \# & $\mathbf{7}$ & $\mathbf{6}$ & $\mathbf{5}$ & $\mathbf{4}$ & $\mathbf{3}$ & $\mathbf{2}$ & $\mathbf{1}$ \\
\hline Cell Location & Road & $\begin{array}{c}\text { Drainage } \\
\text { Ditch }\end{array}$ & Backslope 1 & Bench 1 & Backslope 2 & Bench 2 & Backslope 3 \\
\hline $\begin{array}{c}\text { Height/ Width } \\
\text { (ft.) }\end{array}$ & $\mathrm{n} / \mathrm{a}$ & 22 & 5.25 & 18 & 50 & 15 & 45 \\
\hline $\begin{array}{c}\text { Angle } \\
\text { (Backslope } \\
\text { only) }\end{array}$ & - & $6^{\circ}$ & $40^{\circ}$ & - & $75^{\circ}$ & - & $60^{\circ}$ \\
\hline $\begin{array}{c}\text { Estimated } \\
\text { Surface } \\
\text { Roughness }\end{array}$ & 0.0 & 0.0 & 0.50 & 0.0 & 0.75 & 0.0 & 0.80 \\
\hline $\begin{array}{c}\text { Vegetative } \\
\text { Cover (\%) }\end{array}$ & 0 & 100 & 10 & 5 & 0 & 75 & 50 \\
\hline $\begin{array}{c}\text { Material Type } \\
\text { in Cell }\end{array}$ & Asphalt & Firm Soil & $\begin{array}{c}\text { Hard bedrock } \\
\text { talus }\end{array}$ & $\begin{array}{c}\text { Hard } \\
\text { bedrock }\end{array}$ & Hard bedrock & Hard & Hard bedrock \\
\hline $\begin{array}{c}\text { Initial CRSP } \\
\mathbf{R}_{\mathbf{n}} \text { Range }\end{array}$ & $0.6-1.0$ & $0.12-0.20$ & $0.12-0.20$ & $0.20-0.60$ & $0.20-0.60$ & $0.20-0.60$ & $0.20-0.60$ \\
\hline
\end{tabular}


Table 4.12 Completed Rockfall Tally Table for Hard Bedrock Calibration Site 1

\begin{tabular}{|l|l|l|l|l|l|l|}
\hline \multirow{2}{*}{ Cell \# } & \multicolumn{6}{|c|}{ Rock Diameter (ft.) } \\
\cline { 2 - 7 } & $\mathbf{2 1 . 0}$ & $\mathbf{1 . 0}-\mathbf{1 . 9}$ & $\mathbf{2 . 0}-\mathbf{2 . 9}$ & $\mathbf{3 . 0}-\mathbf{3 . 9}$ & $\mathbf{4 . 0}-\mathbf{4 . 9}$ & $>\mathbf{5 . 0}$ \\
\hline $\mathbf{7}$ & 0 & 0 & 0 & 0 & 0 & 0 \\
\hline $\mathbf{6}$ & 0 & 0 & 0 & 0 & 0 & 0 \\
\hline $\mathbf{4}$ & 82 & 35 & 15 & 2 & 0 & 0 \\
\hline $\mathbf{2}$ & 78 & 38 & 11 & 4 & 0 & 0 \\
\hline Totals: & $\mathbf{1 6 0}$ & $\mathbf{7 3}$ & $\mathbf{2 6}$ & $\mathbf{6}$ & $\mathbf{0}$ & $\mathbf{0}$ \\
\hline $\begin{array}{l}\text { Known } \\
\text { rocks from } \\
\text { Cell 1: }\end{array}$ & 83 & 41 & 11 & 4 & 0 & 0 \\
\hline
\end{tabular}

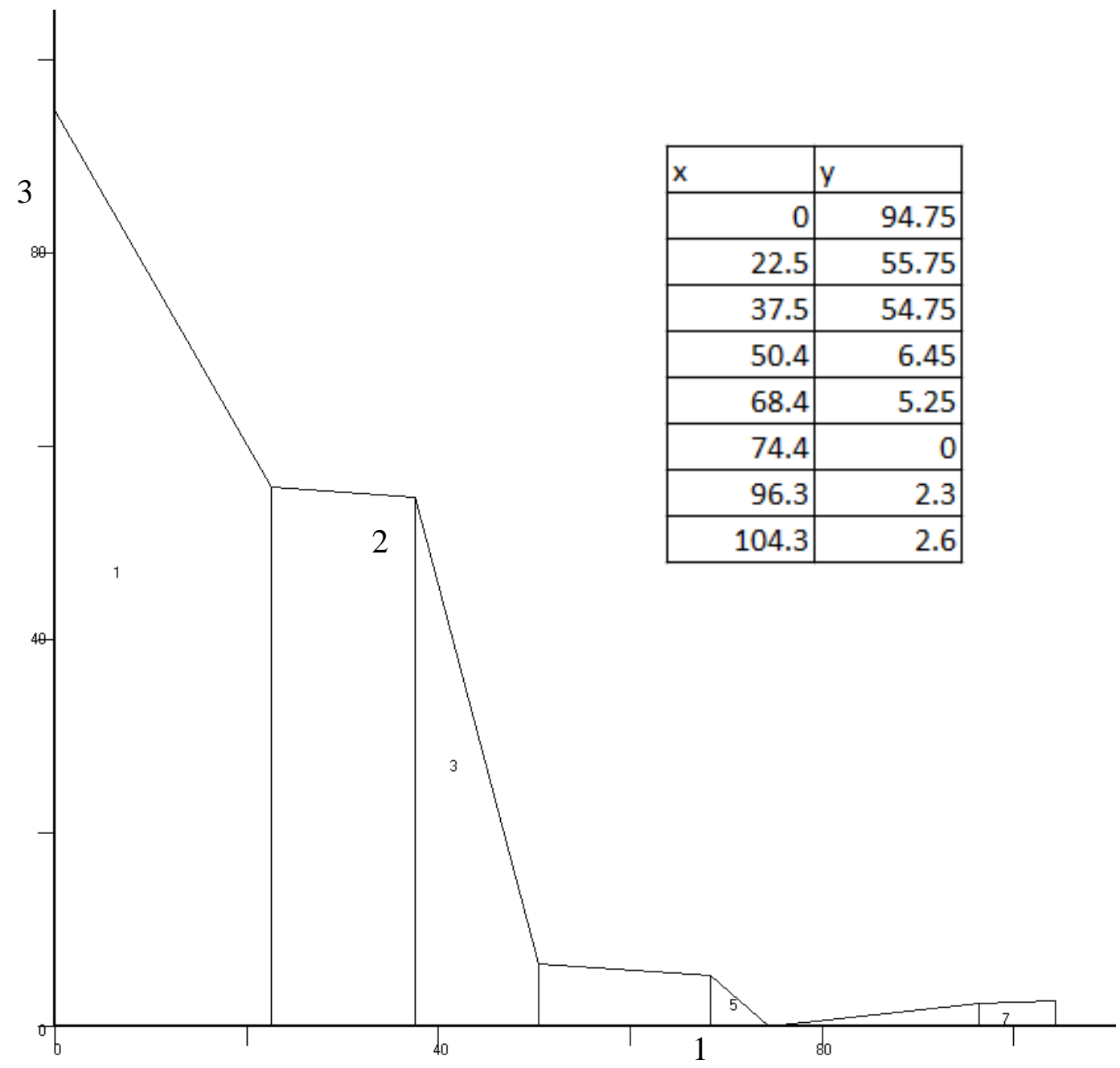

Figure 4.7 Hard Bedrock Calibration Site 1 Slope Profile created in CRSP-2D 
Some aspects of slope geometry were assumed from WV DD-403, as they were not easily measureable at the field site. These include the bench angles (15H:1V) and the roadway grade $\left(2^{\circ}\right)$.

Upon completion of the slope profile, calibration trials were conducted. The initial assumed values for the hard bedrock were: $R_{t}=0.92, R_{n}=0.50$, and rockfall shape $=$ cylindrical. Bench 1 and Backslope 1, as seen in Table 4.11, were not solid bedrock. Thus, they were given coefficient values of $R_{t}=0.80$ and $R_{n}=0.20$. Additionally, it was found in the field visit that fallen rocks between the sizes of 1.0 foot and 1.9 feet had an average size of approximately 1.20 feet in diameter, thus this value was selected as the constant rockfall size in the calibration trials. Field observations also showed that most rockfalls initiated from the bottom 20 feet of backslope 2 , thus this was imitated in the calibration. Lastly, due to the high vegetation found on the Bench 2 , the tangential coefficient was reduced by 0.01 in Cell 2 for the simulation trials listed below, as recommended in the CRSP-2D Manual. Only the rocks known to have fallen from backslope 2 were considered in the calibration process, which can be seen in Table 4.13.

Table 4.13 Trial-and-Error CRSP-2D Calibration for Hard Bedrock with Diameter of 1.20 Feet

\begin{tabular}{|c|c|c|c|c|c|c|c|}
\hline \multirow{2}{*}{$\begin{array}{c}\text { Calibration } \\
\text { Run \# }\end{array}$} & \multicolumn{3}{|c|}{$\begin{array}{c}\text { Hard Bedrock } \\
\text { Parameters }\end{array}$} & \multirow{2}{*}{$\begin{array}{c}\text { Rockfall } \\
\text { Shape }\end{array}$} & \multicolumn{3}{c|}{ Rock Accumulation Tally } \\
\cline { 2 - 4 } & $\mathbf{R}_{\mathbf{n}}$ & $\mathbf{R}_{\mathbf{t}}$ & $\begin{array}{c}\mathbf{R}_{\mathbf{t}} \text { for } \\
\text { Bench 2 }\end{array}$ & & Bench 2 & $\begin{array}{c}\text { Bench } \\
\mathbf{1}\end{array}$ & Ditch/Road \\
\hline Field & - & - & & - & 38 & 3 & 0 \\
\hline $\mathbf{1}$ & 0.50 & 0.92 & 0.91 & Cylindrical & 12 & 16 & 9 \\
\hline $\mathbf{2}$ & 0.35 & 0.92 & 0.91 & Cylindrical & 32 & 7 & 2 \\
\hline $\mathbf{3}$ & 0.30 & 0.92 & 0.91 & Cylindrical & 36 & 3 & 2 \\
\hline $\mathbf{4}$ & 0.30 & 0.92 & 0.91 & Discoidal & 36 & 3 & 2 \\
\hline $\mathbf{5}$ & 0.31 & 0.91 & 0.90 & Cylindrical & 33 & 7 & 1 \\
\hline $\mathbf{6}$ & 0.29 & 0.93 & 0.92 & Cylindrical & 27 & 11 & 3 \\
\hline
\end{tabular}

Without any available hard bedrock slopes capable of a "rock count" calibration method, it is difficult to verify the results found in Table 4.13. An additional slope with similar results, also conducted using the Alternative method, can be found in the Appendix 4. The final calibrated coefficient values for hard bedrock in West Virginia are shown in Table 4.14. 
Table 4.14 Calibrated CRSP-2D Coefficient Values for Soft Bedrock in West Virginia

\begin{tabular}{|c|c|c|}
\hline & $\begin{array}{c}\text { West Virginia } \\
\text { Calibration Results }\end{array}$ & $\begin{array}{c}\text { Suggested Ranges from } \\
\text { Colorado Calibration }\end{array}$ \\
\hline Normal Coefficient, $\mathbf{R}_{\mathbf{n}}$ & $0.29-0.31$ & $0.20-0.60$ \\
\hline Tangential Coefficient, $\mathbf{R}_{\mathbf{t}}$ & $0.91-0.93$ & $0.75-1.0$ \\
\hline Rockfall Shape & Cylindrical or Discoidal & - \\
\hline
\end{tabular}

\subsection{Sensitivity Analysis of WVDOT Cut Slope Design Directives using CRSP-2D}

Prior to modeling existing slopes, a more generalized approach was taken to assess rockfall behavior on the various approved geometric approaches to rock cut slopes by the WVDOT in Design Directive 403 (WV DD-403). An alternative analysis method using the threedimensional version of CRSP was used to determine certain geometric factors which have the strongest effect on rockfall behavior was incorporated in this two-dimensional research (Pentz, 2014). Pentz (2014) suggested creating ranges of values for each slope design parameter addressed within WV DD-403, including bench width, backslope angle, and backslope height. A simulation model must then be created and simulated for each possible parametric value combination (Pentz, 2014). The results are then compiled into charts and graphs to compare the relationships between parametric value changes and rockfall behavior. Additional expected outcomes of this analysis method include whether benches should be considered a rockfall mitigation tactic (see Section 2.3), and whether the current rock cut slope practices in West Virginia are optimal in reduce the negative effects of rockfall.

The WV DD-403, as discussed in Section 2.2, has guidelines and recommendations for four bedrock types commonly found in West Virginia. Table 4.15 is taken directly from Design Directive 403 and shows the comprehensive guidelines for each bedrock type. The issue arising from this table is the lack of focus on cut slopes much taller than 50 feet in height. While slopes under 50 feet high are much more common, from a rockfall mitigation and safety perspective, much more focus should be made on taller slopes (>100 feet). Thus, it is important to simulate the guidelines listed in this table with Colorado Rockfall Simulation Program to ensure they produce safe results with taller slope heights. 
Table 4.15 WV DD-403 Guidelines for Rock Cut Slope Design in Different Bedrock Types (WVDOH 2006)

\begin{tabular}{|c|c|c|c|c|c|c|c|}
\hline \multirow[t]{2}{*}{$\begin{array}{c}\text { TYPE OF } \\
\text { BEDROCK }\end{array}$} & \multirow[t]{2}{*}{$\begin{array}{l}\text { HEIGHT } \\
\text { OF CUT } \\
\text { IN FEET }\end{array}$} & \multicolumn{2}{|c|}{$\begin{array}{l}\text { HEIGHT } \\
\text { BETWEEN } \\
\text { BENCHES } \\
\text { IN FEET }\end{array}$} & \multicolumn{2}{|c|}{$\begin{array}{l}\text { WIDTH OF } \\
\text { BENCHES } \\
\text { IN FEET }\end{array}$} & \multicolumn{2}{|c|}{$\begin{array}{c}\text { BACKSLOPE } \\
\text { RATIO } \\
\text { HORZ./VERT. }\end{array}$} \\
\hline & & $\mathrm{Ha}{ }^{1}$ & $\begin{array}{c}\mathrm{Hb} \mathrm{Hc} \\
\text { etc. }\end{array}$ & $\begin{array}{c}\text { Ws } \\
\text { (min.) }\end{array}$ & $\begin{array}{c}\text { Wb Wc } \\
\text { etc }^{2}\end{array}$ & Sa & $\begin{array}{l}\text { Sb Sc } \\
\text { etc. }^{4}\end{array}$ \\
\hline $\begin{array}{l}\text { 1. Medium hard } \\
\text { to hard } \\
\text { sandstone and } \\
\text { limestone, and } \\
\text { hard shale }\end{array}$ & $\begin{array}{l}\text { over } 50 \\
\text { under } 50\end{array}$ & 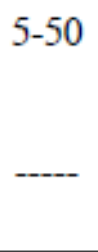 & $50 \pm$ & 10 & $10-20$ & $\begin{array}{l}1 / 6: 1 \\
1 / 6: 1\end{array}$ & $1 / 6: 1$ \\
\hline $\begin{array}{l}\text { 2. Soft sandstone, } \\
\text { medium hard } \\
\text { shale, soft } \\
\text { limestone, } \\
\text { siltstone or an } \\
\text { interbedded } \\
\text { combination }\end{array}$ & $\begin{array}{c}25-50 \\
\text { under } 25\end{array}$ & $5-25$ & $50 \pm$ & 10 & $10-20$ & $1: 1$ & $3 / 4: 1$ \\
\hline $\begin{array}{l}\text { 3. Soft shale } \\
\text { interbedded } \\
\text { with siltstone, } \\
\text { sandstone, or } \\
\text { limestone }\end{array}$ & $\begin{array}{c}\text { over } 50 \\
25-50 \\
\text { under } 25\end{array}$ & $\begin{array}{l}5 \\
5 \\
-\end{array}$ & $20-45$ & $\begin{array}{l}10 \\
10 \\
10\end{array}$ & $10-20$ & $\begin{array}{c}1: 1 \\
1: 1 \\
11 / 2: 1\end{array}$ & $3 / 4: 1$ \\
\hline 4. Soft shale ${ }^{5}$ & $\begin{array}{c}\text { over } 45 \\
25-45 \\
\text { under } 25\end{array}$ & $\begin{array}{l}5 \\
5 \\
\end{array}$ & $20-40$ & $\begin{array}{l}10 \\
10 \\
10\end{array}$ & $10-20$ & $\begin{array}{l}1 \frac{1}{2}: 1 \\
1 \frac{1 / 2: 1}{2: 1}\end{array}$ & $1: 1$ \\
\hline
\end{tabular}

For the slope design sensitivity analysis, to minimize the amount of CRSP models that needed to be simulated, only slopes made up primarily of hard bedrock (limestone and sandstone) and softer bedrock (siltstones, shales, and coals) were analyzed (Pentz, 2014). These are expected to be equivalent to Types 1 and 3 bedrock types in Table 4.4. These were also the two bedrock types that were previously calibrated with CRSP-2D, so the results are expected to be accurate. To achieve these rock conditions, normal coefficient $\left(R_{n}\right)$ values of 0.25 for Type 3 Bedrock and 0.30 for Type 1 Bedrock were selected. Additional variables tested in the sensitivity analysis include (Pentz, 2014):

- Bench width: $15 \mathrm{ft}$., $25 \mathrm{ft}$., $35 \mathrm{ft}$.

- Backslope ratio: Vary depending on Bedrock Type being tested

○ Type 1: 1/6H:1V, 1/4H:1V, 1/2H:1V

○ Type $3: 1 / 2 \mathrm{H}: 1 \mathrm{~V}, 3 / 4 \mathrm{H}: 1 \mathrm{~V}, 1 \mathrm{H}: 1 \mathrm{~V}$

- Backslope heights (height between benches): $50 \mathrm{ft}$., $60 \mathrm{ft}$., $70 \mathrm{ft}$. 
According to Pentz (2014), the bench widths listed above were selected to cover a range of possible widths suggested in WV DD-403. While a footnote in WV DD-403 suggests a minimum bench width of 20 feet when backslopes are over 25 feet in height, it also states that lower standards may be used if necessary. Using bench widths between 15 and 35 feet in the CRSP sensitivity analysis allowed for a more comprehensive analysis of all possible selected design widths within WV DD-403.

Since a different CRSP model needed to be constructed for each parameter listed above, a total of 54 models needed to be evaluated in this sensitivity analysis. The remaining parameters needed to remain constant for all models to reduce inconsistency when comparing results. Each of these parameters and the chosen constant values are discussed in detail below:

- Three benches were given to each slope, with the lowest bench being only 5 feet high from the toe of the slope, as recommended on pages 9-10 of WV DD-403 (Pentz, 2014).

- At the toe of each slope model, a flat $\left(0^{\circ}\right)$ ground extending 200 feet past the toe was provided (Pentz, 2014). While it was observed in the field that small ditches, typically 15-20 feet in length and with an angle of approximately $5^{\circ}$ toward the toe, exist along West Virginia cut slopes, these were installed for rainwater catchment and are assumed to have minimal effect on falling rocks. WV DD-403 does not discuss any type of rockfall mitigation ditches, thus flat runout surfaces were input to show a "worst case" condition for rockfall.

- Surface roughness (S) for each backslope was given a value of 0.5 , while each bench was given a value of 0.01 . These numbers were selected based on average field observations.

- A tangential coefficient $\left(\mathrm{R}_{\mathrm{t}}\right)$ value of 0.92 was selected due to it being an overlapping value for both hard bedrock and soft bedrock found during calibration (Tables 4.9 and 4.14).

- Falling rocks with a cylindrical shape, and having a diameter and height of $1.5 \mathrm{ft}$. were selected as the rockfall parameters for all models. This size and shape provided some of the most accurate calibration trials, mimicking field observed rockfall conditions. An average of every rock size encountered during field calibration yielded a value just under 1.5 , thus this is assumed an accurate-sized rock for the analysis.

- The density of the falling rocks is directly related to the researched unit weights of the slope material. For a more accurate study, laboratory testing should be conducted on rock samples to determine the precise unit weights for the rock types in question. Due to limited time and resources for this research, unit weight values were derived from published literature. For Type 1 Bedrock, consisting mostly of sandstone in West Virginia, a unit weight of $150 \mathrm{lb} / \mathrm{ft}^{3}$ was selected. For Type 3 Bedrock, consisting mostly of interbedded shales, a unit weight of $165 \mathrm{lb} / \mathrm{ft}^{3}$ was selected (Pentz, 2014). These values were assumed average values taken from published ranges for these rock types (Zhao, 2010). For a more accurate sensitivity analysis, rock density values should have been calculated from laboratory testing. However, no laboratory testing was conducted within this research, so published values were substituted.

- The rockfall release zone is the top twelve feet of each slope model. This number was selected for a results comparison with the study conducted using CRSP-3D (Pentz, 2014). Focusing solely on the top of the highest backslope was assumed to provide "worst case" results, which was ideal for this study.

- A total of 1000 rocks were initiated from the release zone. This large of a number was selected to create statistical consistency within CRSP. Due to the randomness algorithms built into the program, simulating a smaller number of falling rocks (ex. 100) can cause 
statistical variations in the results of over $10 \%$ between simulation trials. When 1000 rocks are simulated, the variation between trials drops to less than $3 \%$.

\subsubsection{WV DD-403 Type 1 Bedrock CRSP-2D Sensitivity Study Results}

The following output data was collected from each simulation trial:

- Average velocity, kinetic energy, and bounce height at toe of slope

- Average distance rocks continued past toe of slope (runout distance)

- Farthest runout distance past toe of slope

- Percentage of total simulated rocks that were retained on each bench

Tables 4.16, 4.17, and 4.18 display the results from each of these trials for Type 1 Bedrock (hard bedrock). The more obvious conclusions can be observed without the aid of graphs, such as the steeper and higher backslopes become, the higher the velocity, kinetic energy, and bounce height at the toe of slope become. Additionally, larger benches tend to catch more falling rocks.

Graphical observations and conclusions can be found after the tables.

Table 4.16 Results for CRSP Simulations involving Type 1 Bedrock and $50 \mathrm{ft}$. Backslope Heights

\begin{tabular}{|c|c|c|c|c|c|c|c|c|c|}
\hline $\begin{array}{l}\text { Bench } \\
\text { width } \\
\text { (ft.) }\end{array}$ & $\begin{array}{c}\text { Backslope } \\
\text { Ratio } \\
\text { (H:V) }\end{array}$ & $\begin{array}{c}\text { Avg. } \\
\text { velocity } \\
\text { @ toe } \\
\text { (ft./sec) }\end{array}$ & $\begin{array}{c}\text { Avg. } \\
\text { kinetic } \\
\text { energy @ } \\
\text { toe (kips) }\end{array}$ & $\begin{array}{c}\text { Avg. } \\
\text { bounce } \\
\text { height @ } \\
\text { toe (ft.) }\end{array}$ & $\begin{array}{l}\text { Avg. } \\
\text { runout } \\
\text { past toe } \\
\text { (ft.) }\end{array}$ & $\begin{array}{c}\text { Farthest } \\
\text { runout } \\
\text { past toe } \\
\text { (ft.) }\end{array}$ & $\begin{array}{c}\text { \% Rocks } \\
\text { retained } \\
\text { on } \\
\text { Bench } 3\end{array}$ & $\begin{array}{c}\% \text { Rocks } \\
\text { retained } \\
\text { on } \\
\text { Bench } 2\end{array}$ & $\begin{array}{c}\% \text { Rocks } \\
\text { retained } \\
\text { on } \\
\text { Bench } 1\end{array}$ \\
\hline \multirow[t]{3}{*}{15} & $1 / 2: 1$ & 28 & 8.6 & 5.3 & 37.5 & 165 & $1 \%$ & $2 \%$ & $1 \%$ \\
\hline & $1 / 4: 1$ & 35 & 14.7 & 7.8 & 21.6 & 110 & $7 \%$ & $7 \%$ & $6 \%$ \\
\hline & $1 / 6: 1$ & 40 & 17.2 & 14.8 & 21.4 & 60 & $65 \%$ & $4 \%$ & $3 \%$ \\
\hline \multirow[t]{3}{*}{25} & $1 / 2: 1$ & 16 & 2.4 & 3.5 & 18.5 & 58 & $31 \%$ & $21 \%$ & $19 \%$ \\
\hline & $1 / 4: 1$ & 12 & 1.3 & 4.4 & 11.2 & 36 & $43 \%$ & $37 \%$ & $11 \%$ \\
\hline & $1 / 6: 1$ & 11 & 1.3 & 4.8 & 14.8 & 35 & $82 \%$ & $11 \%$ & $3 \%$ \\
\hline \multirow[t]{3}{*}{35} & $1 / 2: 1$ & 0 & 0 & 0 & 0 & 0 & $93 \%$ & $5 \%$ & $2 \%$ \\
\hline & $1 / 4: 1$ & 0 & 0 & 0 & 0 & 0 & $99 \%$ & $1 \%$ & $0 \%$ \\
\hline & $1 / 6: 1$ & 0 & 0 & 0 & 0 & 0 & $99 \%$ & $1 \%$ & $0 \%$ \\
\hline
\end{tabular}


Table 4.17 Results for CRSP Simulations involving Type 1 Bedrock and $60 \mathrm{ft}$. Backslopes Heights

\begin{tabular}{|c|c|c|c|c|c|c|c|c|c|}
\hline $\begin{array}{c}\text { Bench } \\
\text { width } \\
\text { (ft.) }\end{array}$ & $\begin{array}{c}\text { Backslope } \\
\text { Ratio } \\
\text { (H:V) }\end{array}$ & $\begin{array}{c}\text { Avg. } \\
\text { velocity } \\
\text { @ toe } \\
\text { (ft./sec) }\end{array}$ & $\begin{array}{c}\text { Avg. } \\
\text { kinetic } \\
\text { energy @ } \\
\text { toe (kips) }\end{array}$ & $\begin{array}{c}\text { Avg. } \\
\text { bounce } \\
\text { height @ } \\
\text { toe (ft.) }\end{array}$ & $\begin{array}{l}\text { Avg. } \\
\text { runout } \\
\text { past toe } \\
\text { (ft.) }\end{array}$ & $\begin{array}{c}\text { Farthest } \\
\text { runout } \\
\text { past toe } \\
\text { (ft.) }\end{array}$ & $\begin{array}{c}\% \text { Rocks } \\
\text { retained } \\
\text { on } \\
\text { Bench } 3\end{array}$ & $\begin{array}{c}\% \text { Rocks } \\
\text { retained } \\
\text { on } \\
\text { Bench } 2\end{array}$ & $\begin{array}{c}\text { \% Rocks } \\
\text { retained } \\
\text { on } \\
\text { Bench } 1\end{array}$ \\
\hline \multirow[t]{3}{*}{15} & $1 / 2: 1$ & 30 & 10000 & 6.3 & 38 & 170 & $0 \%$ & $2 \%$ & $1 \%$ \\
\hline & $1 / 4: 1$ & 39 & 17200 & 9.4 & 24.6 & 140 & $6 \%$ & $7 \%$ & $8 \%$ \\
\hline & $1 / 6: 1$ & 52 & 24400 & 25.5 & 22.7 & 70 & $61 \%$ & $3 \%$ & $3 \%$ \\
\hline \multirow[t]{3}{*}{25} & $1 / 2: 1$ & 18 & 3200 & 3.9 & 23 & 85 & $29 \%$ & $18 \%$ & $15 \%$ \\
\hline & $1 / 4: 1$ & 15 & 2600 & 4.8 & 17.5 & 50 & $41 \%$ & $24 \%$ & $14 \%$ \\
\hline & $1 / 6: 1$ & 16 & 3400 & 5.3 & 13.8 & 34 & $73 \%$ & $13 \%$ & $5 \%$ \\
\hline \multirow[t]{3}{*}{35} & $1 / 2: 1$ & 17 & 3200 & 0 & 10.9 & 18 & $56 \%$ & $30 \%$ & $9 \%$ \\
\hline & $1 / 4: 1$ & 0 & 0 & 0 & 0 & 0 & $89 \%$ & $9 \%$ & $2 \%$ \\
\hline & $1 / 6: 1$ & 0 & 0 & 0 & 0 & 0 & $96 \%$ & $3 \%$ & $1 \%$ \\
\hline
\end{tabular}

Table 4.18 Results for CRSP Simulations involving Type 1 Bedrock and $70 \mathrm{ft}$. Backslope Heights

\begin{tabular}{|c|c|c|c|c|c|c|c|c|c|}
\hline $\begin{array}{c}\text { Bench } \\
\text { width } \\
\text { (ft.) }\end{array}$ & $\begin{array}{c}\text { Backslope } \\
\text { Ratio } \\
\text { (H:V) }\end{array}$ & $\begin{array}{c}\text { Avg. } \\
\text { velocity } \\
\text { @ toe } \\
\text { (ft./sec) }\end{array}$ & $\begin{array}{c}\text { Avg. } \\
\text { kinetic } \\
\text { energy @ } \\
\text { toe (kips) }\end{array}$ & $\begin{array}{c}\text { Avg. } \\
\text { bounce } \\
\text { height @ } \\
\text { toe (ft.) }\end{array}$ & $\begin{array}{l}\text { Avg. } \\
\text { runout } \\
\text { past toe } \\
\text { (ft.) }\end{array}$ & $\begin{array}{c}\text { Farthest } \\
\text { runout } \\
\text { past toe } \\
\text { (ft.) }\end{array}$ & $\begin{array}{c}\% \text { Rocks } \\
\text { retained } \\
\text { on } \\
\text { Bench } 3\end{array}$ & $\begin{array}{c}\% \text { Rocks } \\
\text { retained } \\
\text { on } \\
\text { Bench } 2\end{array}$ & $\begin{array}{c}\% \text { Rocks } \\
\text { retained } \\
\text { on } \\
\text { Bench } 1\end{array}$ \\
\hline \multirow[t]{3}{*}{15} & $1 / 2: 1$ & 34 & 12600 & 7.1 & 48 & 172 & $0 \%$ & $1 \%$ & $1 \%$ \\
\hline & $1 / 4: 1$ & 41 & 19500 & 11.6 & 28.7 & 125 & $6 \%$ & $7 \%$ & $7 \%$ \\
\hline & $1 / 6: 1$ & 56 & 27200 & 37.4 & 28.6 & 114 & $56 \%$ & $3 \%$ & $3 \%$ \\
\hline \multirow[t]{3}{*}{25} & $1 / 2: 1$ & 21 & 5000 & 4.2 & 31.2 & 120 & $26 \%$ & $17 \%$ & $12 \%$ \\
\hline & $1 / 4: 1$ & 21 & 6100 & 6.3 & 14 & 82 & $37 \%$ & $25 \%$ & $17 \%$ \\
\hline & $1 / 6: 1$ & 18 & 5200 & 2.3 & 14.5 & 54 & $66 \%$ & $12 \%$ & $9 \%$ \\
\hline \multirow[t]{3}{*}{35} & $1 / 2: 1$ & 15 & 1800 & 3.2 & 11.8 & 35 & $70 \%$ & $17 \%$ & $7 \%$ \\
\hline & $1 / 4: 1$ & 0 & 0 & 0 & 0 & 0 & $82 \%$ & $14 \%$ & $4 \%$ \\
\hline & $1 / 6: 1$ & 0 & 0 & 0 & 0 & 0 & $91 \%$ & $7 \%$ & $2 \%$ \\
\hline
\end{tabular}


Focusing on the objectives stated before conducting the sensitivity analysis, the results are discussed in the following ways:

- The last three bars on the right of Figure 4.8 show that, regardless of the backslope heights and angles, 35 foot benches will catch the majority of smaller falling rocks. Backslopes at 1/4:1 or steeper, coupled with 35 foot benches, will catch virtually all falling rocks before they reach the toe of the slope. It can be concluded from the results that benches smaller than 25 feet are typically not effective as a rockfall mitigation technique. WV DD-403 suggests a minimum bench width of 20 feet on slopes over 50 feet in height, but the CRSP-2D results show that $90 \%$ retention (the ODOT standard minimum acceptable percentage of rockfall retention) is not reached for most slope angles until a minimum $25 \mathrm{ft}$. bench width is used. Figure 4.8 depicts these observations.

- The tabular results show that both backslope angle and bench width both have effects on rockfall runout, while the backslope height has a much smaller effect. Figure 4.9 compares the two factors with higher sensitivity side by side, showing that smaller benches and shallower slope angles cause noticeably larger average rockfall runout compared to larger bench widths and steeper slopes. Figure $4.9 \mathrm{~b}$ shows that there is virtually no change in average runout between 1/4:1 and 1/6:1 backslope angles, suggesting that Type 1 Bedrock cut slopes should not be cut any shallower than $1 / 4: 1$ to reduce rockfall runout.

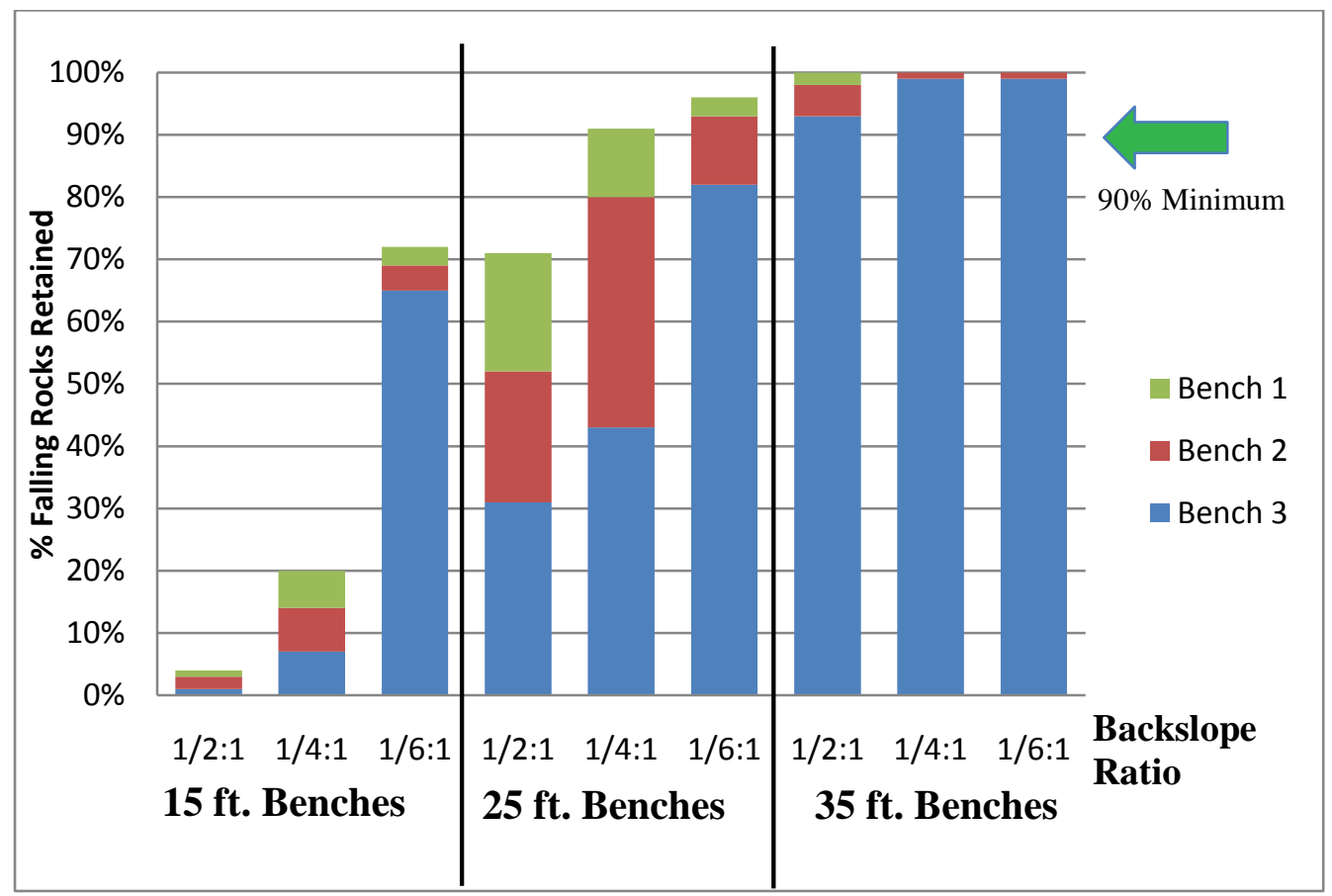

Figure 4.8 Graph depicting the ability of benches to be used as rockfall catchment on Type 1 Bedrock slopes with different backslope angles 
a.)

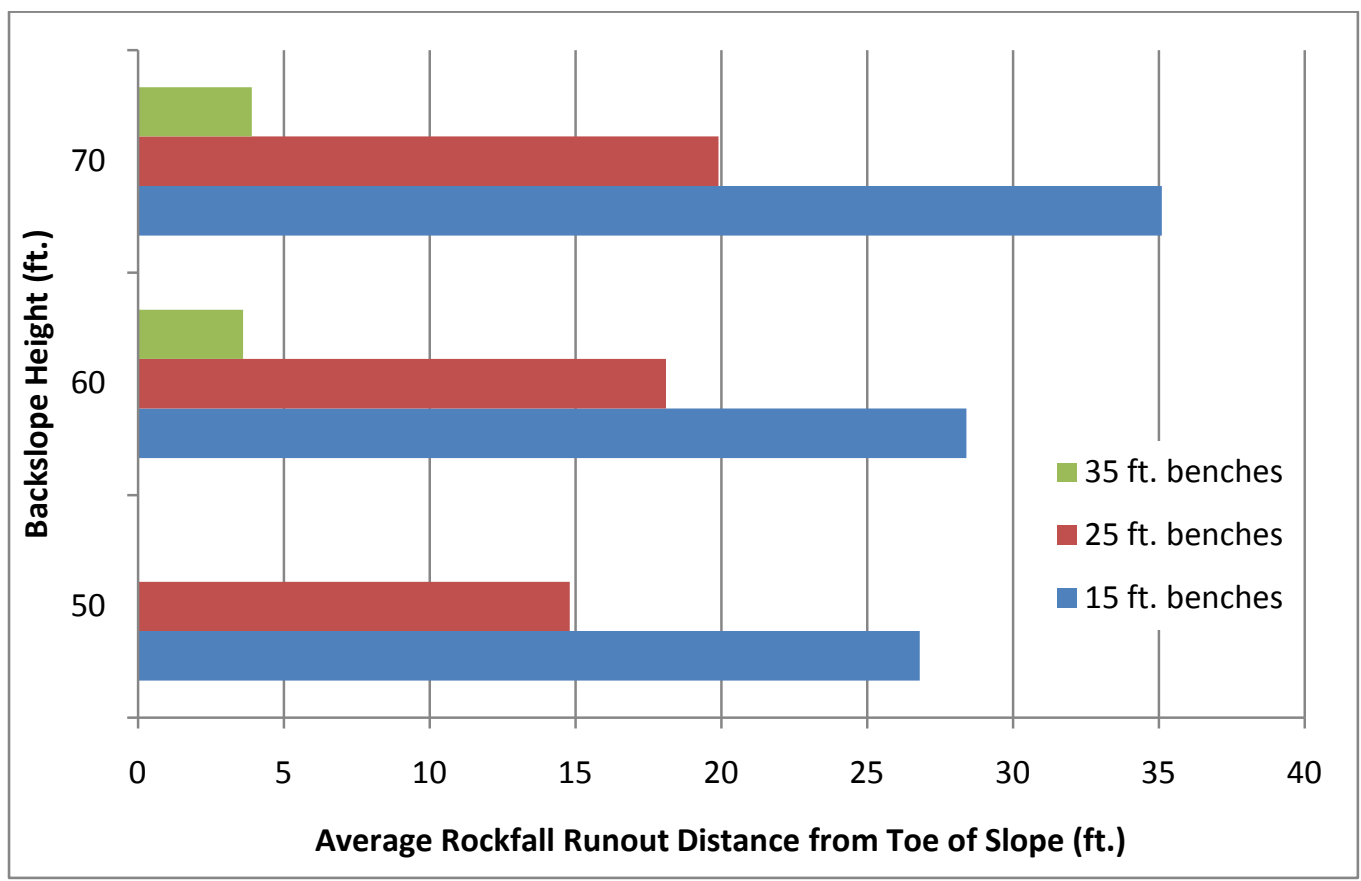

b.)

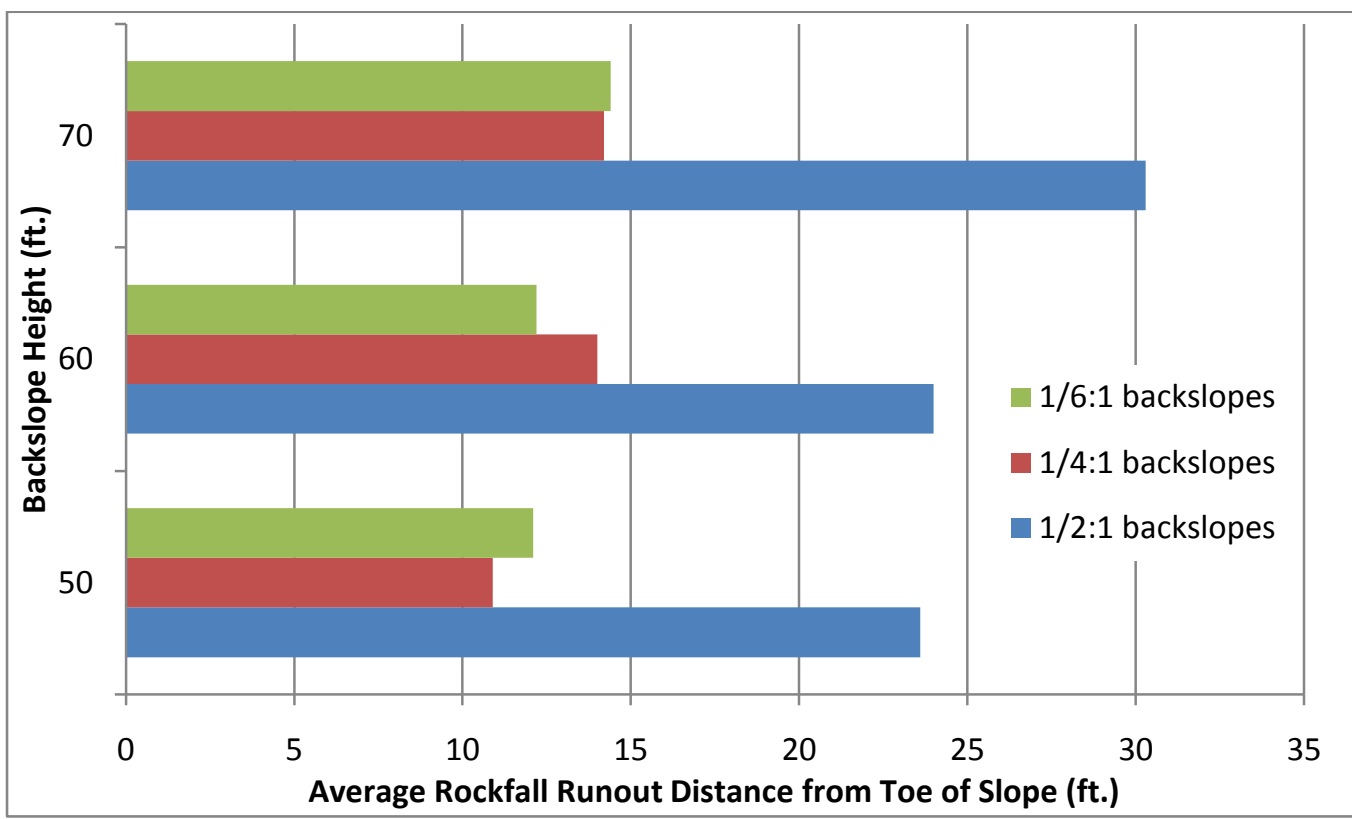

Figure 4.9 Graphs depicting the relationships between Bench Width (4.6a.) vs. Average Rockfall Runout Distance, and Backslope Angle (4.6b) vs. Average Rockfall Runout Distance for Type 1 Bedrock slopes

WV DD-403 lists a minimum of $20 \mathrm{ft}$. wide benches and $1 / 2 \mathrm{H}: 1 \mathrm{~V}$ backslopes for Type 1 Bedrock, but rockfall simulations show these minimum requirements to be inadequate as a rockfall mitigation technique. Figure 4.8 shows that even a $25 \mathrm{ft}$. wide bench only retains $70 \%$ of falling rocks when the backslope ratio is $1 / 2: 1$. Additionally, Figure 4.9a shows that the same combination of bench width and backslope ratio produces an average runout of 20 feet, meaning approximately half of all rocks that leave the slope will reach the roadway if only a $20 \mathrm{ft}$. buffer between roadway shoulder and toe of slope is used. Thus, WV DD-403's Bedrock Type 1 (see Table 4.4) should be designed with a suggested absolute minimum of $25 \mathrm{ft}$. wide benches, to be used with a minimum backslope angle of $1 / 4: 1$ (or $76^{\circ}$ ) to produce a safe on-slope rockfall 
retention rate of at least the minimum acceptable $90 \%$ and a reduced average rockfall runout to below $15 \mathrm{ft}$.

It is important to keep in mind that rockfall mitigation is only one of many considerations when designing highway rock cut slopes, including slope stability, minimizing undercutting, proper drainage, and erosion control. Thus, the manipulation of bench and backslope geometry should only be considered when all aspects of cut slope design are taken into account.

\subsubsection{WV DD-403 Type 3 Bedrock CRSP-2D Sensitivity Study Results}

As was done with the Type 1 Bedrock results in Section 4.3.1, the following data was collected from each simulation trial conducted on Type 3 Bedrock (soft rock):

- Average velocity, kinetic energy, and bounce height at toe of slope

- Average distance rocks continued past toe of slope (runout distance)

- Farthest runout distance past toe of slope

- Percentage of total simulated rocks that were retained on each bench

Tables 4.8, 4.9, and 4.10 display the results of the 27 simulation runs for Type 3 Bedrock. Results were similar to those of Type 1 Bedrock, but with some key noticeable differences:

- WV DD-403 recommends backslope angles for Type 3 Bedrock be placed at 3/4:1 (or $53.1^{\circ}$ ). This shallower angle is used for slope stability and erosion control considerations. The sensitivity analysis considered 1/2:1, 3/4:1, and 1:1 backslope angles for Type 3, and found that with smaller benches (15 ft.) and backslope angles shallower than $1 / 2: 1(3 / 4: 1,1: 1)$, falling rocks are not retained on the benches. With these parameters, the highest percentage retention was $45 \%$. Thus, it can be concluded that when it is necessary to lay back a slope for stability purposes, benches must be wider than $15 \mathrm{ft}$. to be used to rockfall mitigation purposes.

- However, $35 \mathrm{ft}$. wide benches were able to catch virtually all falling rocks in the Type 3 Bedrock analysis. Thus, it should be recommended that where possible, $35 \mathrm{ft}$. wide benches should be used when designing rock cut slopes with Type 3 Bedrock and backslope angles shallower than 1/2:1. Slightly smaller bench widths ( $25 \mathrm{ft}$. wide) are almost acceptable when a backslope angle of 1/2:1 is used (average on-slope rockfall retention of $81 \%$ ).

- Bounce heights and kinetic energies at the toe of the slope are much lower compared to hard rock slopes. This is expected, due to the shallower backslope angles and "softer" rock absorbing more of the kinetic energy with each bounce down the slope compared to the Type 1 Bedrock slopes. 
Table 4.19 Results for CRSP Simulations involving Type 3 Bedrock and 50 ft. Backslope Heights

\begin{tabular}{|c|c|c|c|c|c|c|c|c|c|}
\hline $\begin{array}{c}\text { Bench } \\
\text { width } \\
\text { (ft.) }\end{array}$ & $\begin{array}{c}\text { Backslope } \\
\text { Ratio } \\
\text { (H:V) }\end{array}$ & $\begin{array}{c}\text { Avg. } \\
\text { velocity } \\
\text { @ toe } \\
\text { (ft./sec) }\end{array}$ & $\begin{array}{c}\text { Avg. } \\
\text { kinetic } \\
\text { energy @ } \\
\text { toe (kips) }\end{array}$ & $\begin{array}{c}\text { Avg. } \\
\text { bounce } \\
\text { height @ } \\
\text { toe (ft.) }\end{array}$ & $\begin{array}{l}\text { Avg. } \\
\text { runout } \\
\text { past toe } \\
\text { (ft.) }\end{array}$ & $\begin{array}{l}\text { Farthest } \\
\text { runout } \\
\text { past toe } \\
\text { (ft.) }\end{array}$ & $\begin{array}{c}\% \text { Rocks } \\
\text { retained } \\
\text { on } \\
\text { Bench } 3\end{array}$ & $\begin{array}{c}\% \text { Rocks } \\
\text { retained } \\
\text { on } \\
\text { Bench } 2\end{array}$ & $\begin{array}{c}\% \text { Rocks } \\
\text { retained } \\
\text { on } \\
\text { Bench } 1\end{array}$ \\
\hline \multirow[t]{3}{*}{15} & 1:1 & 28.1 & 8500 & 3.9 & 49.3 & 95 & $0 \%$ & $0 \%$ & $0 \%$ \\
\hline & $3 / 4: 1$ & 24.3 & 6500 & 3.9 & 34.6 & 112 & $0 \%$ & $0 \%$ & $0 \%$ \\
\hline & $1 / 2: 1$ & 26.3 & 8300 & 4.4 & 22.2 & 107 & $5 \%$ & $7 \%$ & $5 \%$ \\
\hline \multirow[t]{3}{*}{25} & 1:1 & 17.4 & 2800 & 1.6 & 12.5 & 65 & $26 \%$ & $10 \%$ & $9 \%$ \\
\hline & $3 / 4: 1$ & 16.4 & 2500 & 2.4 & 11.8 & 51 & $29 \%$ & $16 \%$ & $12 \%$ \\
\hline & $1 / 2: 1$ & 14.4 & 1900 & 3 & 9.8 & 33 & $56 \%$ & $20 \%$ & $9 \%$ \\
\hline \multirow[t]{3}{*}{35} & 1:1 & 0 & 0 & 0 & 0 & 0 & $98 \%$ & $2 \%$ & $0 \%$ \\
\hline & $3 / 4: 1$ & 0 & 0 & 0 & 0 & 0 & $98 \%$ & $2 \%$ & $0 \%$ \\
\hline & $1 / 2: 1$ & 0 & 0 & 0 & 0 & 0 & $99 \%$ & $1 \%$ & $0 \%$ \\
\hline
\end{tabular}

Table 4.20 Results for CRSP Simulations involving Type 3 Bedrock and $60 \mathrm{ft}$. Backslope Heights

\begin{tabular}{|c|c|c|c|c|c|c|c|c|c|}
\hline $\begin{array}{l}\text { Bench } \\
\text { width } \\
\text { (ft.) }\end{array}$ & $\begin{array}{c}\text { Backslope } \\
\text { Ratio } \\
\text { (H:V) }\end{array}$ & $\begin{array}{c}\text { Avg. } \\
\text { velocity } \\
\text { @ toe } \\
\text { (ft./sec) }\end{array}$ & $\begin{array}{c}\text { Avg. } \\
\text { kinetic } \\
\text { energy @ } \\
\text { toe (kips) }\end{array}$ & $\begin{array}{c}\text { Avg. } \\
\text { bounce } \\
\text { height @ } \\
\text { toe (ft.) }\end{array}$ & $\begin{array}{l}\text { Avg. } \\
\text { runout } \\
\text { past toe } \\
\text { (ft.) }\end{array}$ & $\begin{array}{c}\text { Farthest } \\
\text { runout } \\
\text { past toe } \\
\text { (ft.) }\end{array}$ & $\begin{array}{c}\% \text { Rocks } \\
\text { retained } \\
\text { on } \\
\text { Bench } 3\end{array}$ & $\begin{array}{c}\% \text { Rocks } \\
\text { retained } \\
\text { on } \\
\text { Bench } 2\end{array}$ & $\begin{array}{c}\% \text { Rocks } \\
\text { retained } \\
\text { on } \\
\text { Bench } 1\end{array}$ \\
\hline \multirow[t]{3}{*}{15} & 1:1 & 30.3 & 9900 & 4 & 56.7 & 110 & $0 \%$ & $0 \%$ & $0 \%$ \\
\hline & $3 / 4: 1$ & 28.1 & 9100 & 4 & 42.1 & 126 & $0 \%$ & $0 \%$ & $0 \%$ \\
\hline & $1 / 2: 1$ & 30.7 & 11200 & 5.2 & 37.3 & 128 & $3 \%$ & $4 \%$ & $3 \%$ \\
\hline \multirow[t]{3}{*}{25} & 1:1 & 19.3 & 3700 & 2.4 & 19.6 & 75 & $15 \%$ & $7 \%$ & $7 \%$ \\
\hline & $3 / 4: 1$ & 17.5 & 3000 & 2.9 & 18.2 & 71 & $20 \%$ & $14 \%$ & $12 \%$ \\
\hline & $1 / 2: 1$ & 15 & 2100 & 3.6 & 15.3 & 42 & $50 \%$ & $20 \%$ & $12 \%$ \\
\hline \multirow[t]{3}{*}{35} & 1:1 & 0 & 0 & 0 & 0 & 0 & $90 \%$ & $8 \%$ & $2 \%$ \\
\hline & $3 / 4: 1$ & 0 & 0 & 0 & 0 & 0 & $91 \%$ & $7 \%$ & $2 \%$ \\
\hline & $1 / 2: 1$ & 0 & 0 & 0 & 0 & 0 & $95 \%$ & $4 \%$ & $1 \%$ \\
\hline
\end{tabular}


Table 4.21 Results for CRSP Simulations involving Type 3 Bedrock and 70 ft. Backslope Heights

\begin{tabular}{|c|c|c|c|c|c|c|c|c|c|}
\hline $\begin{array}{c}\text { Bench } \\
\text { width } \\
\text { (ft.) }\end{array}$ & $\begin{array}{c}\text { Backslope } \\
\text { Ratio } \\
\text { (H:V) }\end{array}$ & $\begin{array}{c}\text { Avg. } \\
\text { velocity @ } \\
\text { toe } \\
\text { (ft./sec) }\end{array}$ & $\begin{array}{c}\text { Avg. } \\
\text { kinetic } \\
\text { energy @ } \\
\text { toe (kips) }\end{array}$ & $\begin{array}{c}\text { Avg. } \\
\text { bounce } \\
\text { height @ } \\
\text { toe (ft.) }\end{array}$ & $\begin{array}{l}\text { Avg. } \\
\text { runout } \\
\text { past toe } \\
\text { (ft.) }\end{array}$ & $\begin{array}{c}\text { Farthest } \\
\text { runout } \\
\text { past toe } \\
\text { (ft.) }\end{array}$ & $\begin{array}{c}\% \text { Rocks } \\
\text { retained } \\
\text { on Bench } \\
3\end{array}$ & $\begin{array}{c}\% \text { Rocks } \\
\text { retained } \\
\text { on Bench } \\
2\end{array}$ & $\begin{array}{c}\% \text { Rocks } \\
\text { retained } \\
\text { on Bench } \\
1\end{array}$ \\
\hline \multirow[t]{3}{*}{15} & 1:1 & 32.4 & 11400 & 4.1 & 61.9 & 140 & $0 \%$ & $0 \%$ & $0 \%$ \\
\hline & $3 / 4: 1$ & 31 & 11000 & 4.3 & 50.7 & 133 & $0 \%$ & $0 \%$ & $0 \%$ \\
\hline & $1 / 2: 1$ & 35.7 & 14800 & 6.6 & 38 & 132 & $2 \%$ & $4 \%$ & $5 \%$ \\
\hline \multirow[t]{3}{*}{25} & $1: 1$ & 21.2 & 4700 & 2.9 & 26 & 90 & $8 \%$ & $5 \%$ & $3 \%$ \\
\hline & $3 / 4: 1$ & 19.3 & 3900 & 3.4 & 20.7 & 83 & $18 \%$ & $13 \%$ & $10 \%$ \\
\hline & $1 / 2: 1$ & 16.2 & 2700 & 3.8 & 17 & 47 & $44 \%$ & $18 \%$ & $15 \%$ \\
\hline \multirow[t]{3}{*}{35} & $1: 1$ & 14.7 & 2000 & 0.9 & 7 & 20 & $73 \%$ & $17 \%$ & $7 \%$ \\
\hline & $3 / 4: 1$ & 15.2 & 2000 & 1.2 & 9.8 & 23 & $77 \%$ & $16 \%$ & $5 \%$ \\
\hline & $1 / 2: 1$ & 0 & 0 & 0 & 0 & 0 & $86 \%$ & $11 \%$ & $3 \%$ \\
\hline
\end{tabular}

The rockfall simulations for Type 3 Bedrock produced similar results to those for Type 1 Bedrock. Figures 4.10 and 4.11 are graphical representations of the Type 3 results shown in Tables 4.19 through 4.21 .

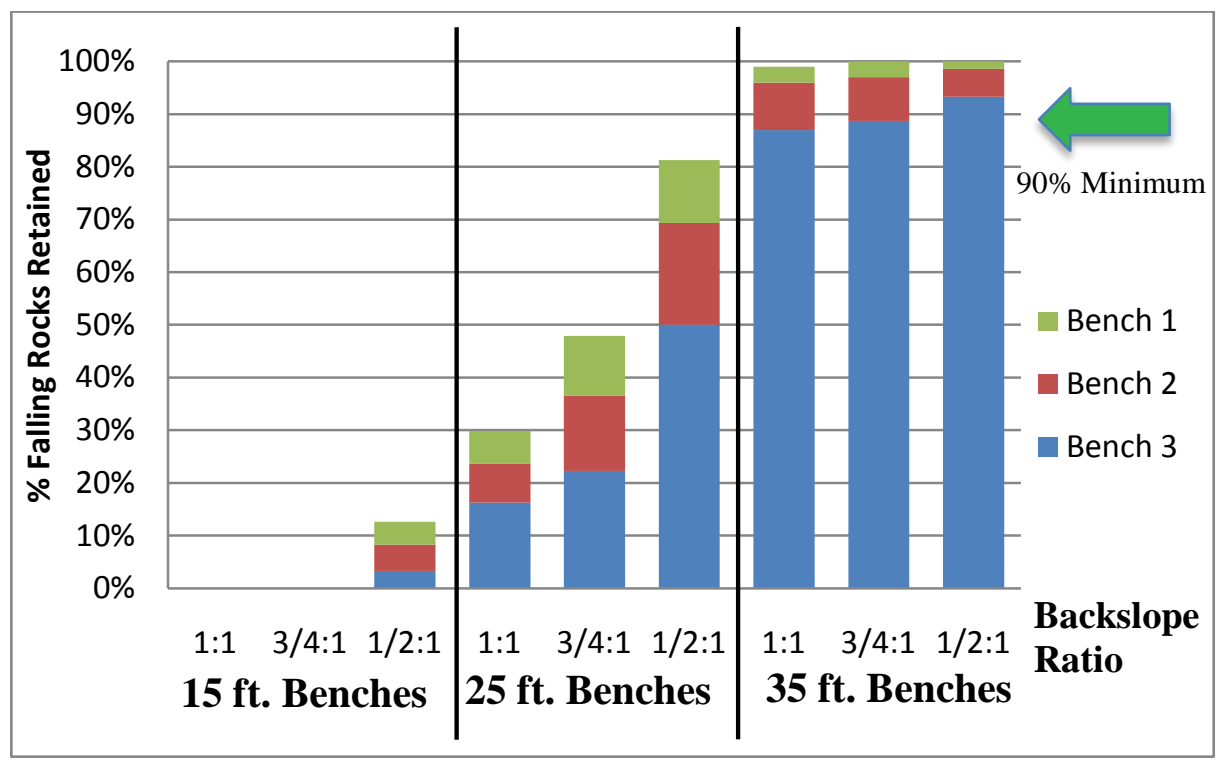

Figure 4.10 Graph depicting the ability of benches to be used as rockfall catchment on slopes with different backslope angles. 
a.)

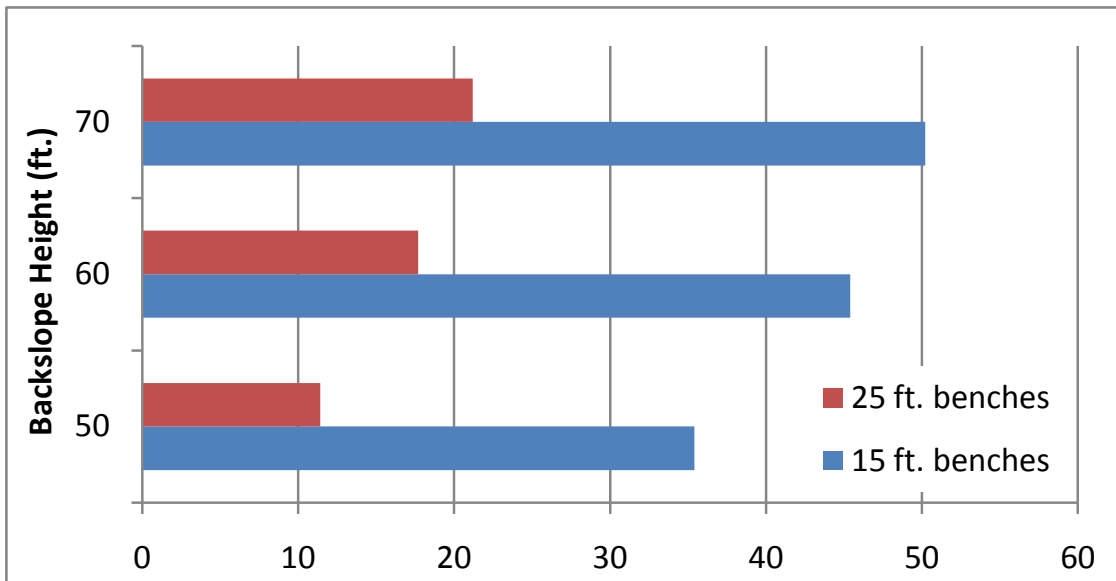

Average Rockfall Runout Distance from Toe of Slope (ft.)

b.)

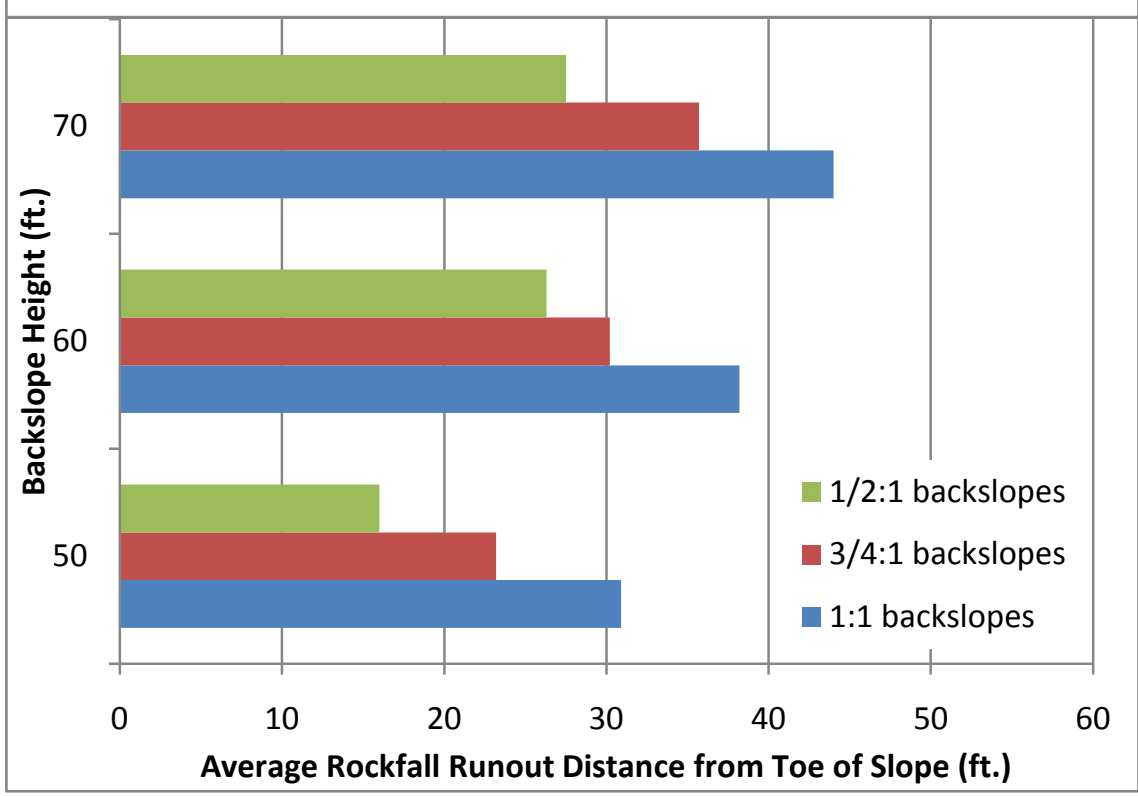

Figure 4.11 Graphs depicting the relationships between Bench Width (4.10a) vs. Average Rockfall Runout Distance, and Backslope Angle (4.10b) vs. Average Rockfall Runout Distance

Figure 4.10 depicts a very strong relationship between bench width and rockfall retention when dealing with Type 3 Bedrock slopes. Due to the shallower backslope angles associated with softer bedrock slopes, bench widths below 35 feet were completely unacceptable as a primary rockfall mitigation technique.

Figure 4.11 shows that, while Type 3 Bedrock slopes produce lower overall toe of slope hazard (lower average velocity and bounce height) compared to Type 1 slopes, rockfall runout becomes a larger concern when using shallower backslope angles. The overall average rockfall runout from toe of slope is significantly higher for Type 3 Bedrock slopes compared to Type 1 Bedrock slopes (Type $1=16.6 \mathrm{ft}$.; Type $3=20.8 \mathrm{ft}$.). This is due to both shallower backslope angles and denser rockfall material, which creates more potential energy.

Comparing the two graphs in Figure 4.11 shows that bench width has a much larger effect on runout than backslope angle. Due to nearly $100 \%$ on-slope retention with $35 \mathrm{ft}$. backslopes, that data series is not even included in Figure 4.11a. Thus, the main conclusion from these results is that when designing Type 3 Bedrock cut slopes using Table 4.4 in WV DD-403, it is 
recommended to use $35 \mathrm{ft}$. wide benches to ensure proper on-slope rockfall mitigation, regardless of selected backslope angle. If $35 \mathrm{ft}$. benches are not a possibility due to Right-ofWay issues, additional mitigation techniques must be installed on the slope to safely retain falling rocks.

\subsubsection{Implementation of a Catchment Ditch in CRSP-2D Sensitivity Analysis}

After modeling Type 1 and Type 3 Bedrock cut slopes to WV DD-403 design standards, recommendations were made based on observations of the results. Due to overall high average rockfall runout values throughout the simulations, a proposed Rockfall Catchment Area Design, or RCAD ditch, was modeled and tested using CRSP-2D. RCAD ditches, or modified Ritchie Ditches, were discussed in detail in Section 2.1.1.

The issue with the RCAD ditch design is that it is only applicable to cut slopes 80 feet in total height (see Figure 4.12) and shorter. It would be difficult to attempt to interpolate from the charts and tables proper RCAD ditch design for slopes greater than 150 feet high, so general assumptions needed to be made:

- The angle of the RCAD ditch needs to be a recoverable surface for roadway users, or a guiderail system would have to also be installed (ODOT, 2001). Guiderails are an additional cost and inhibit the ability to easily clean the ditch. Thus, the steepest ditch angle is $4 \mathrm{H}: 1 \mathrm{~V}$, or $14^{\circ}$ from horizontal.

- To save Right-of-Way acquisition and additional excavation costs, it is important for the ditch to take up the smallest "footprint" possible to still be effective. For the sake of the sensitivity analysis, a ditch with a width of 25 feet from toe of slope presumed roadway shoulder was selected. At a 4:1 ditch slope ratio, this creates a ditch that extends 6 feet below roadway grade, with a 1 foot flat bottom to assist with erosion and drainage concerns.

- Removing the lowest bench in the slope profiles created a lower backslope height up to 90 feet. This causes a variability in the backslope heights compared to the slope profiles tested in Sections 4.3.1 and 4.3.2, which potentially altered the average kinetic energy and velocity of the falling rocks. However, the results still show the increase in rockfall retention with the implementation of an RCAD-style ditch compared to the current WV DD-403 method of a lower catchment bench, even with increased rock energies.

- A sketch of the modified RCAD ditch created for this CRSP-2D sensitivity analysis can be found in Figure 4.13 below. 


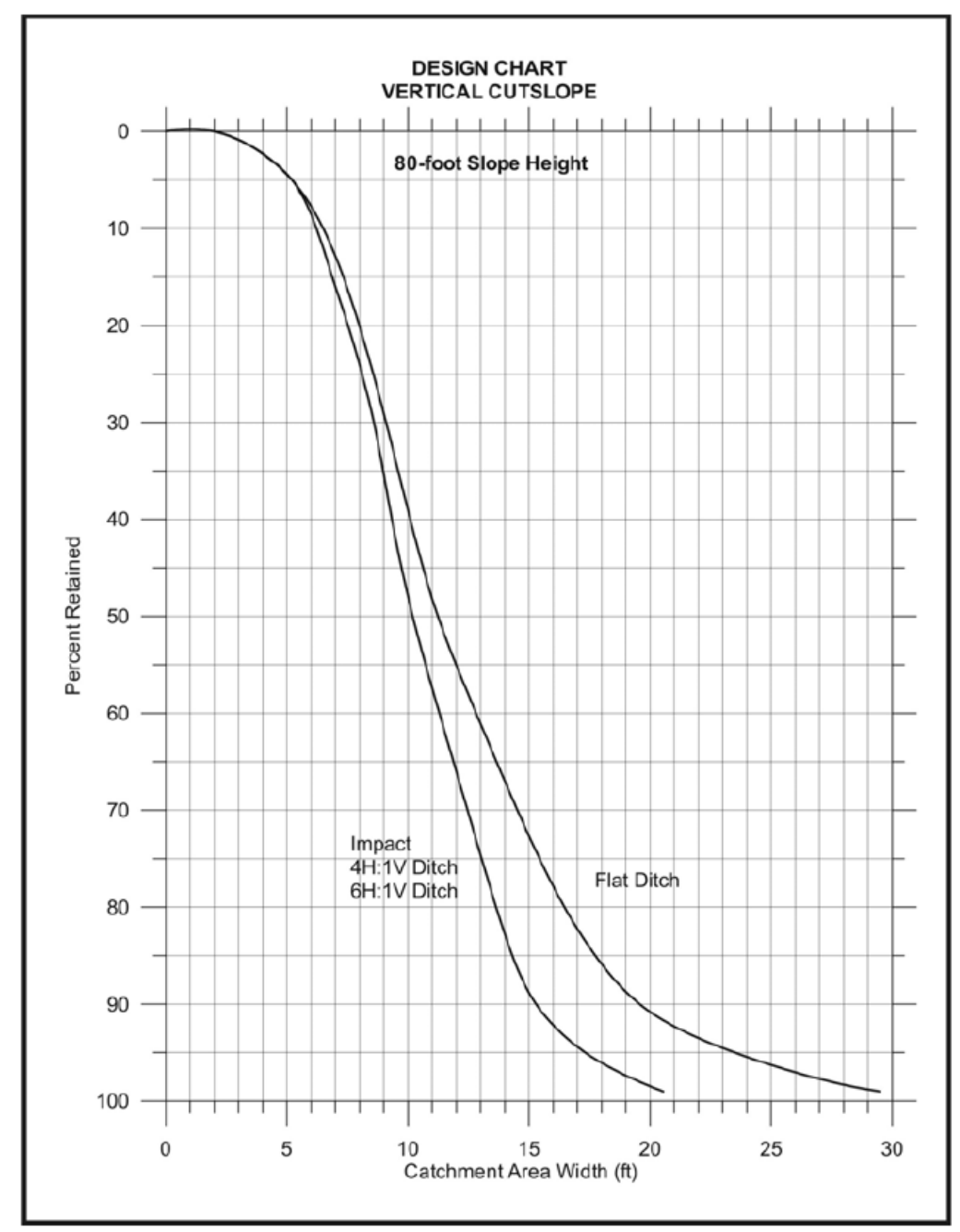

Figure 4.12 Sample RCAD Ditch Design Chart for 80-ft. slopes (ODOT 2001)

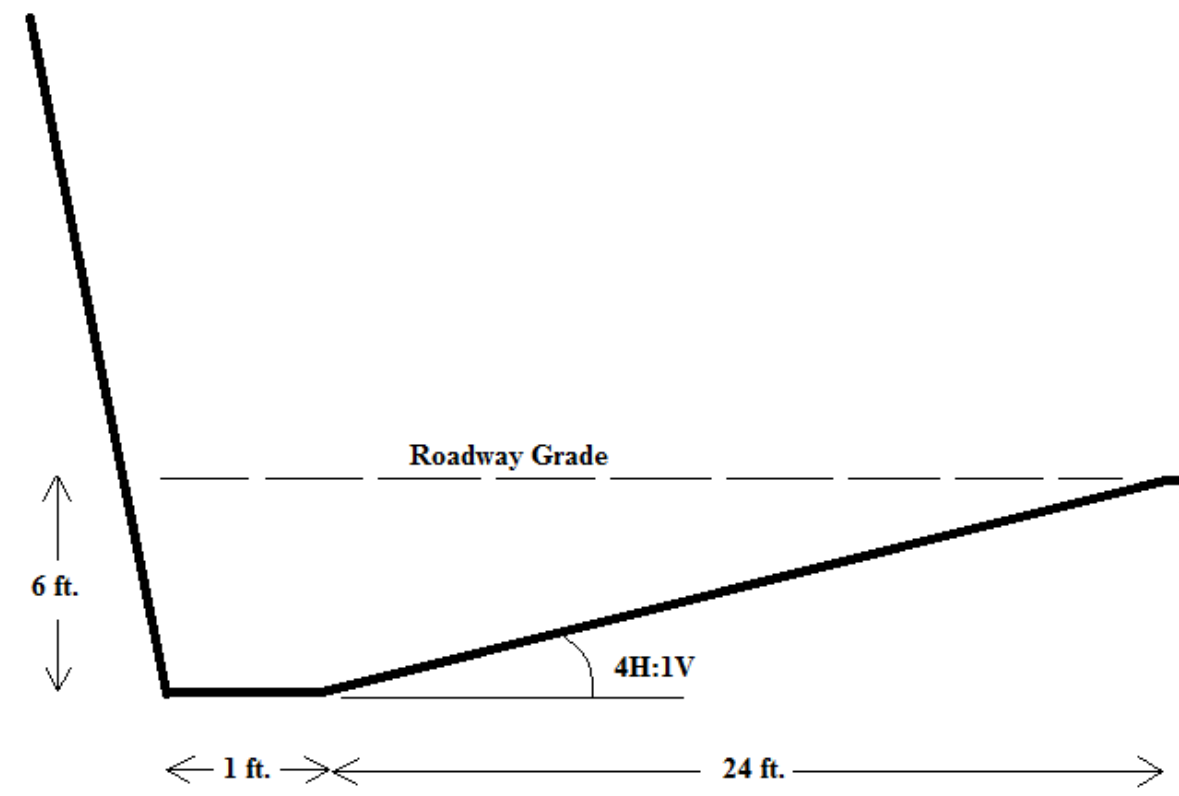

Figure 4.13 Visual Representation of the modified RCAD ditch developed for the CRSP$2 D$ sensitivity analysis 
For the remainder of this section, the original cut slope models with a lower rockfall catchment bench ( 5 feet from the roadway grade) will be referred to as "lower bench slopes," and the modified slope models with the removal of the lower bench and the addition of the RCAD ditch 6 feet below roadway grade will be referred to as "RCAD ditch slopes."

After re-simulating the slope models with the new ditch modifications, many results changed. Figure 4.14 shows the most drastic observable difference between the lower bench slopes and the RCAD ditch slopes in regards to rockfall catchment. The RCAD ditch, with an average width equal to that of the lower catchment ditch, caught an average of $65 \%$ more rocks than the bench design that WV DD-403 recommends, when simulated with CRSP-2D. While a cost analysis was not conducted, it should be considered that the reduction in additional mitigation and maintenance costs due to greater catchment exceeds the increase in excavation costs to implement a ditch design. Thus it is recommended that WVDOT adjusts their rock cut slope design directives to implement a rockfall catchment ditch similar to the Rockfall Catchment Area Design guidelines developed by Oregon DOT, in place of the current practice of a lower catchment bench.

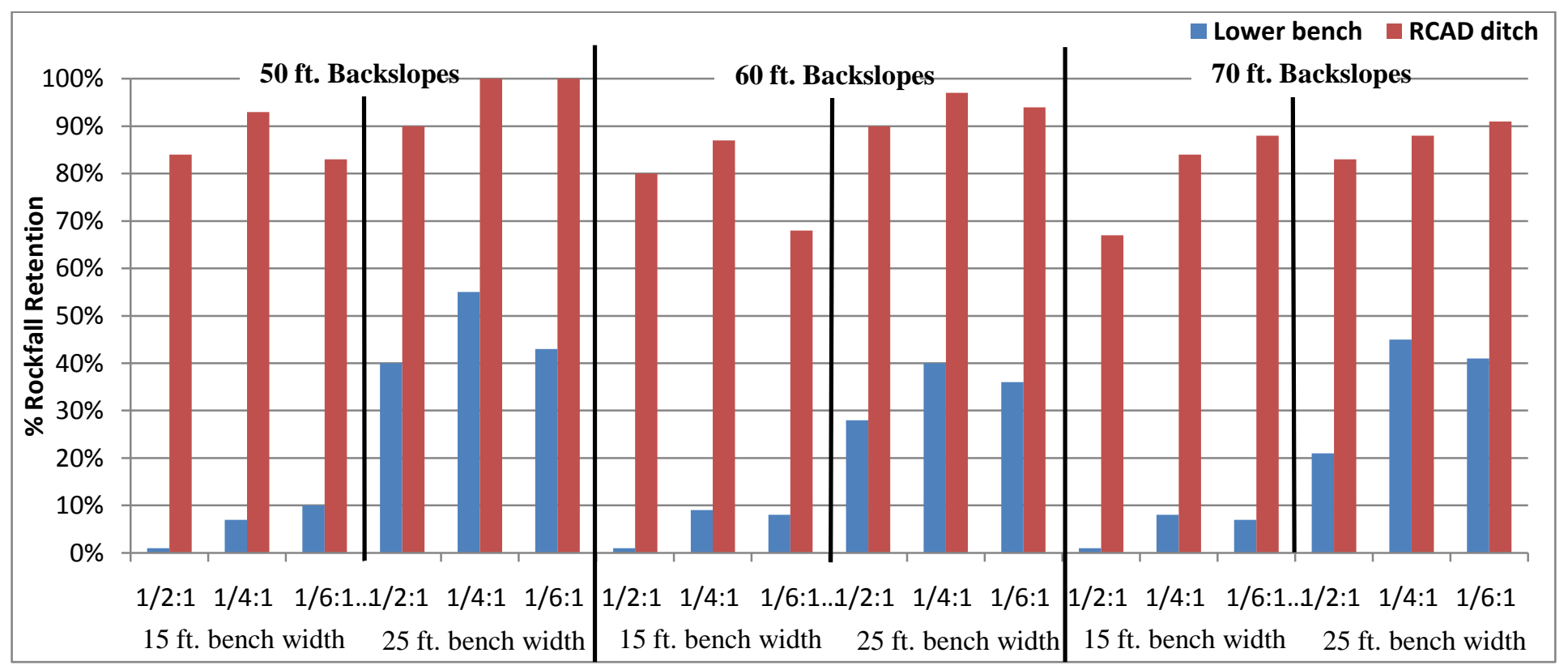

Figure 4.14 Graph comparing the rockfall catchment effectiveness of a WV DD-403 designed lower bench (blue) versus a RCAD designed ditch (red)

Table 4.22 and 4.23 below show a comparison of rockfall behavior results for the CRSP-2D simulation trials between the original WV DD-403 slope designs using $25 \mathrm{ft}$. benches and the slope design with RCAD ditches. Only $25 \mathrm{ft}$. benches were compared due to the identical width of the RCAD-style ditch, thus identical X-coordinates for the both analysis partitions could be compared. The observed characteristics were rockfall velocity and kinetic energy. 
Table 4.22 Comparisons of the change in Velocity and Kinetic Energy at the roadway edge between using a catchment bench and using an RCADstyle ditch for Type 1 Bedrock Slopes

\begin{tabular}{|c|c|c|c|}
\hline $\begin{array}{c}\text { Backslope } \\
\text { Height (ft.) }\end{array}$ & $\begin{array}{l}\text { Backslope } \\
\text { Ratio } \\
\text { (H:V) }\end{array}$ & $\begin{array}{c}\text { Change in Velocity at } \\
\text { roadway edge } \\
\text { (ft./sec.) }\end{array}$ & $\begin{array}{l}\text { Change in Kinetic } \\
\text { Energy at roadway } \\
\text { edge (kips) }\end{array}$ \\
\hline \multirow[t]{3}{*}{50} & $1 / 2: 1$ & -6.8 & -1200 \\
\hline & $1 / 4: 1$ & -12 & -1300 \\
\hline & $1 / 6: 1$ & -11 & -1300 \\
\hline \multirow[t]{3}{*}{60} & $1 / 2: 1$ & -7.8 & -1500 \\
\hline & $1 / 4: 1$ & $+17.4 *$ & $+10100 *$ \\
\hline & $1 / 6: 1$ & $+35.7 *$ & $+17600^{*}$ \\
\hline \multirow[t]{3}{*}{70} & $1 / 2: 1$ & -5.3 & -500 \\
\hline & $1 / 4: 1$ & $+26.6^{*}$ & $+14400 *$ \\
\hline & $1 / 6: 1$ & $+45.8^{*}$ & $+23300 *$ \\
\hline
\end{tabular}

Table 4.23 Comparisons of the change in Velocity and Kinetic Energy at the roadway edge between using a catchment bench and using an RCADstyle ditch for Type 3 Bedrock Slopes

\begin{tabular}{|c|c|c|c|}
\hline Backslope & $\begin{array}{c}\text { Backslope } \\
\text { Ratio } \\
\text { (H:V) }\end{array}$ & $\begin{array}{c}\text { Change in Velocity at } \\
\text { roadway edge } \\
\text { (ft./sec.) }\end{array}$ & $\begin{array}{c}\text { Change in Kinetic } \\
\text { Energy at roadway } \\
\text { edge (kips) }\end{array}$ \\
\hline \multirow{2}{*}{$\mathbf{5 0}$} & $\mathbf{1 : 1}$ & -7.6 & -1300 \\
\cline { 2 - 4 } & $\mathbf{3} / \mathbf{4}: \mathbf{1}$ & -6.5 & -1000 \\
\cline { 2 - 4 } & $\mathbf{1} / \mathbf{2}: \mathbf{1}$ & -14.4 & -1900 \\
\hline \multirow{2}{*}{$\mathbf{6 0}$} & $\mathbf{1 : 1}$ & -8.6 & -1900 \\
\cline { 2 - 4 } & $\mathbf{3} \mathbf{4}: \mathbf{1}$ & -7.6 & -1400 \\
\cline { 2 - 4 } & $\mathbf{1} / \mathbf{2}: \mathbf{1}$ & -6.5 & -900 \\
\hline \multirow{2}{*}{$\mathbf{7 0}$} & $\mathbf{1 : 1}$ & -9.6 & -2600 \\
\cline { 2 - 4 } & $\mathbf{3} / \mathbf{4}: \mathbf{1}$ & -8.2 & -2000 \\
\cline { 2 - 4 } & $\mathbf{1} / \mathbf{2}: \mathbf{1}$ & -6.6 & -1200 \\
\hline
\end{tabular}


Comparing Table 4.22 to Table 4.23, it can be seen that the implementation of a catchment ditch has a more overall positive effect on Type 3 Bedrock slopes than Type 1 Bedrock slopes. A significant reduction in both velocity and kinetic energy occurred in all simulation trials for the Type 3 Bedrock slopes. However, for the Type 1 Bedrock slopes at steeper backslope ratios (1/4:1 and 1/6:1), the velocity and kinetic energy had substantial increases when the RCAD-style ditch was added. The red oval in Figure 4.15 shows that these results occurred due to Bench 1 becoming a launching feature for rocks falling from the upper backslope, causing some of the rocks to land outside of the ditch during freefall. While less than $10 \%$ of rocks are reaching this point, the few rocks that do are highly dangerous to roadway users. There are many options to remediate this issue, including extension of the ditch, adjustment of Bench 1 height, or implementation of a small barrier.

As previously stated, and confirmed with the results, the implementation of a rockfall catchment ditch at the toe of rock cut slopes with a similar design to RCAD (ODOT, 2001) is a much more successful method for rockfall catchment compared to the current WVDOT methods described in WV DD-403. A significant reduction in rocks reaching the roadway, along with an overall reduction in velocity and kinetic energy of the rocks that do leave can be expected when the lowest bench is replaced with a ditch of equal width.

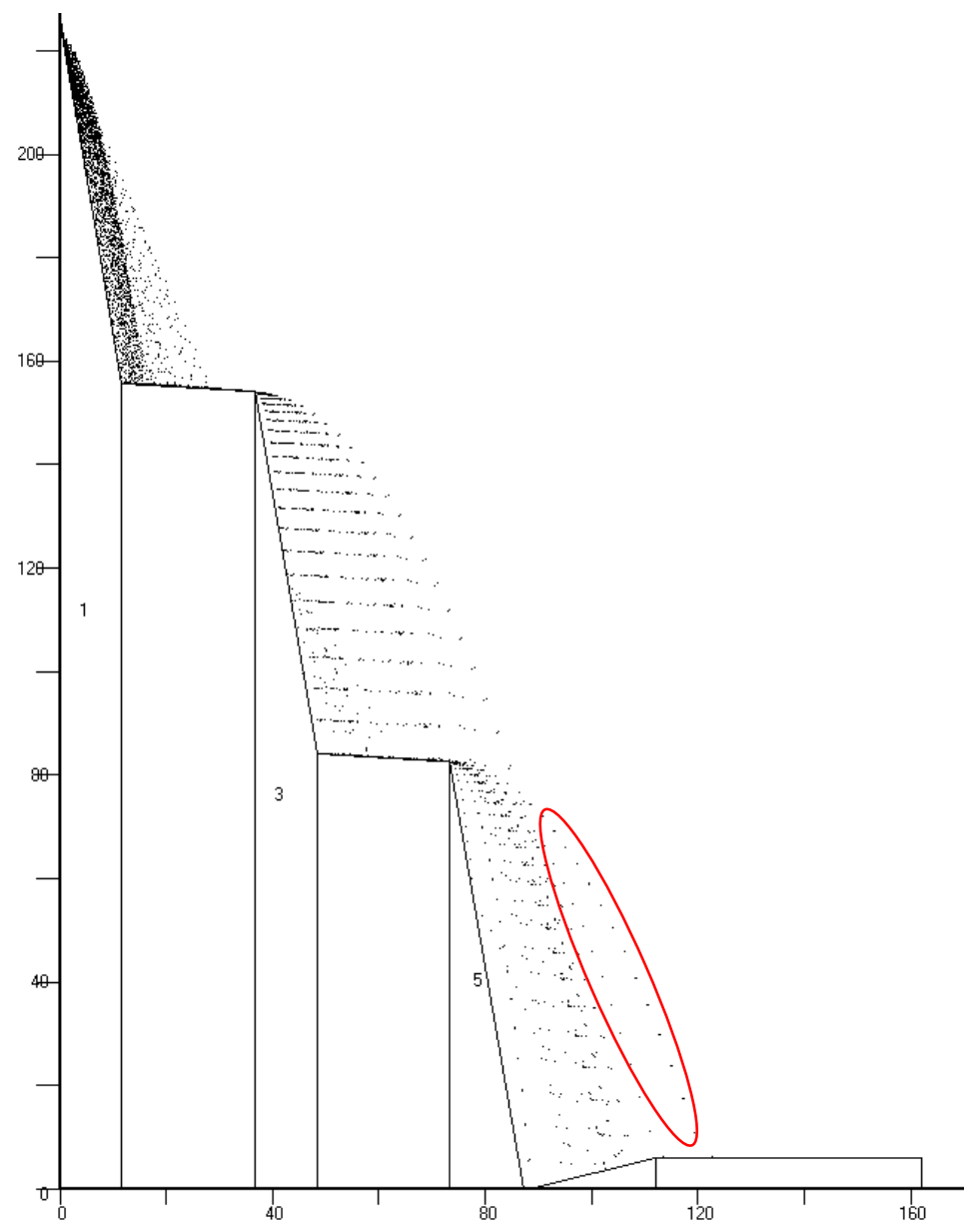

Figure 4.15 CRSP-2D Simulation Results for a Type 1 Bedrock slope with $70 \mathrm{ft}$. tall backslopes, $25 \mathrm{ft}$. wide benches, and an RCAD-style ditch at toe. The red circle depicts the small percentage of rocks that launched over the ditch 


\subsubsection{Summary of Findings for CRSP-2D Sensitivity Analysis}

To reiterate the results shown in Figures 4.8, 4.10, and 4.14, Figure 4.16 depicts a summary of these findings. The scatter plots show the trend lines for on-slope retention percentages with increased bench width. Figures 4.16a and 4.16c compare the relationships between bench width and percent retention for hard and soft bedrock slopes at different backslope ratios. Figures $4.16 \mathrm{~b}$ and $4.16 \mathrm{~d}$ compare these same relationships for slopes with RCAD ditches at the toe.
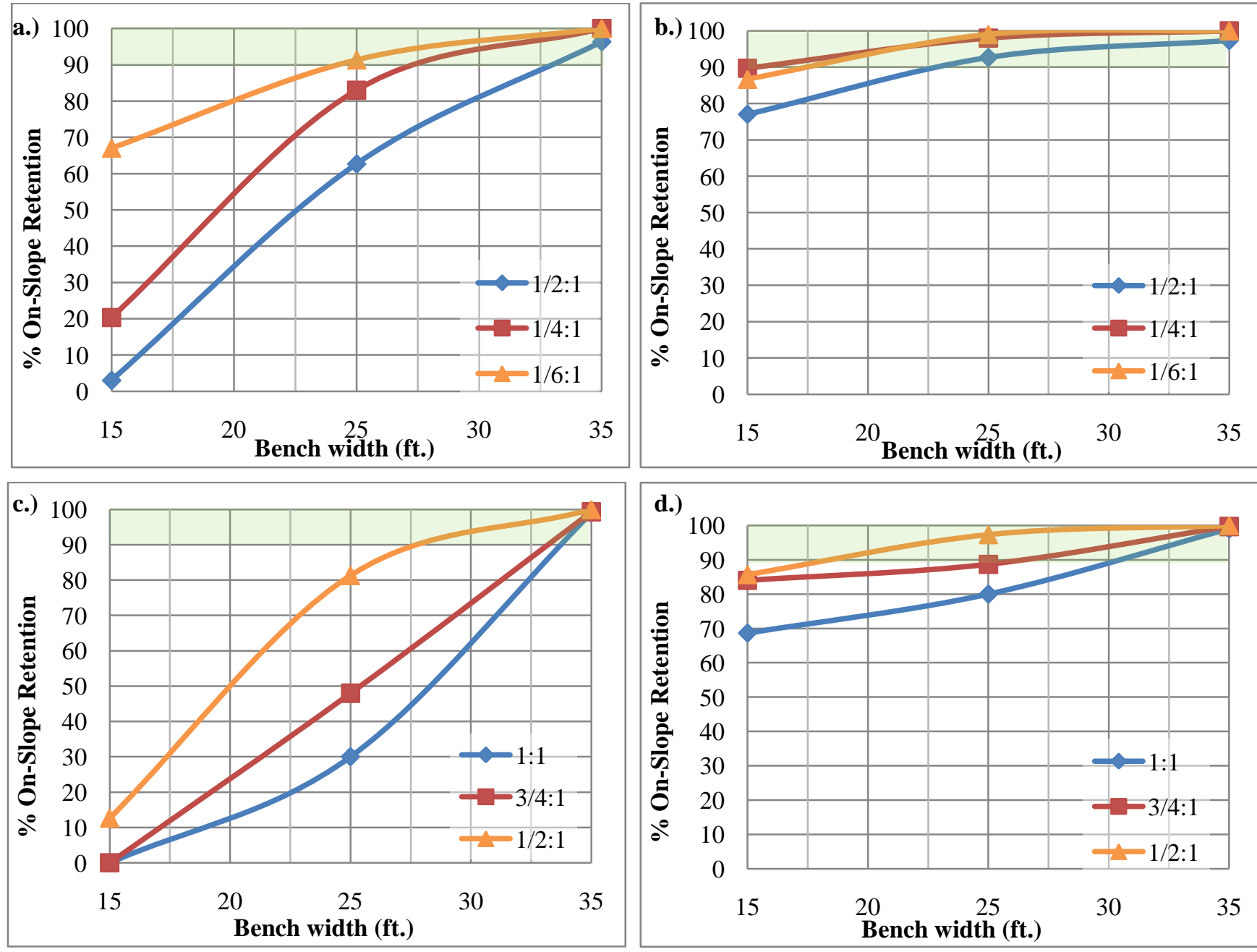

Figure 4.16 Bench Width vs. Percent On-Slope Retention for a.) Hard Bedrock w/o ditch, b.) Hard Bedrock with RCAD-style ditch, c.) Soft Bedrock w/o ditch, d.) Soft Bedrock with RCAD-style ditch.

The graphs in Figure 4.16 above show the following:

- Bench widths under 25 feet will not adequately retain rockfall (at least $90 \%$ retention) without the aid of an RCAD-style ditch at the toe of slope.

- Steeper slopes allow for more on-slope rockfall retention than shallower slopes. Unless $35 \mathrm{ft}$. benches are being used, backslopes should never be laid back at a ratio of $1 \mathrm{H}: 1 \mathrm{~V}$ or shallower unless necessary for structural stability.

While not shown in the figure, the data suggests that height between benches has the lowest effect on the overall percentage of on-slope rockfall retention. Backslope angle, bench width, and presence of ditch all have much greater effect on the results. Additional conclusions and related 
recommendations were made based off of running rockfall simulations using CRSP-2D on multiple models built to represent the standards and recommendations put forth by the WVDOT in their rock cut slope design directive (WV DD-403):

- Bench widths greater than 25 feet may successfully be used as an on-slope rockfall catchment method on both Type 1 and Type 3 Bedrock slopes. However, it is important to remember that the upper benches must be easily accessed and maintained when infilling occurs to ensure clean catchment benches.

- Steeper-angled backslopes (within the realm of recommended angles in WV DD-403) allow for more rockfall to be retained on the benches. Thus, slopes do not need to be laid back flatter than necessary just for rockfall mitigation purposes as it has the opposite effect.

- There should be consideration into implementing a rockfall catchment ditch system at the toe of all rock cut slopes over 100 feet in height, regardless of the number of geotechnical benches on the slope. The current toe of slope method, discussed in WV DD-403, involving a bench 5 feet from the ditch bottom, is not a successful rockfall catchment method. However, a ditch with the same width as the lower bench can successfully catch nearly all rockfall that leaves the upper benches. Oregon DOT's RCAD design guide (ODOT, 2001) should be a resource when developing this ditch system.

- It is important to remember that this sensitivity analysis was conducted using 1.5 foot diameter falling rocks, and has not been further tested with larger or smaller diameter rockfall. Thus, these recommendations are only validated with this average-size rockfall.

A flowchart was created to aid in the rock cut slope design process when using WV DD-403 (Figure 4.17), along with supplemental table, Table 4.24. This flowchart models the findings from the sensitivity analysis. The focus of the flowchart is rockfall simulation, and additional considerations may need to be made when conducting stability analysis on the slope. A step-bystep design guide for designing highway rock cut slopes with the aid of CRSP-2D can be found in Appendix VI.

Table 4.24 Supplemental table to Design Flow Chart in Figure 4.16

\begin{tabular}{|c|c|c|}
\hline Bedrock Type & $\begin{array}{c}\text { Potential } \\
\text { Backslope Ratios }\end{array}$ & $\begin{array}{c}\text { Minimum Bench } \\
\text { Width (ft.) }\end{array}$ \\
\hline \multirow{2}{*}{ Type 1 } & $1 / 6 \mathrm{H}: 1 \mathrm{~V}$ & 25 \\
\cline { 2 - 3 } & $1 / 4 \mathrm{H}: 1 \mathrm{~V}$ & 25 \\
\cline { 2 - 3 } & $1 / 2 \mathrm{H}: 1 \mathrm{~V}$ & 30 \\
\hline \multirow{2}{*}{ Type 2 } & $1 / 4 \mathrm{H}: 1 \mathrm{~V}$ & 25 \\
\cline { 2 - 3 } & $1 / 2 \mathrm{H}: 1 \mathrm{~V}$ & 30 \\
\cline { 2 - 3 } & $3 / 4 \mathrm{H}: 1 \mathrm{~V}$ & 30 \\
\hline \multirow{2}{*}{ Type 3 } & $1 / 2 \mathrm{H}: 1 \mathrm{~V}$ & 30 \\
\cline { 2 - 3 } & $3 / 4 \mathrm{H}: 1 \mathrm{~V}$ & 30 \\
\cline { 2 - 3 } & $1 \mathrm{H}: 1 \mathrm{~V}$ & 35 \\
\hline \multirow{2}{*}{ Type 4 } & $1 \mathrm{H}: 1 \mathrm{~V}$ & \multirow{2}{*}{ N/A } \\
\cline { 2 - 3 } & $11 / 2 \mathrm{H}: 1 \mathrm{~V}$ & \multicolumn{2}{|c|}{} \\
\cline { 2 - 3 } & $2 \mathrm{H}: 1 \mathrm{~V}$ & \multicolumn{2}{|c|}{30} \\
\hline
\end{tabular}




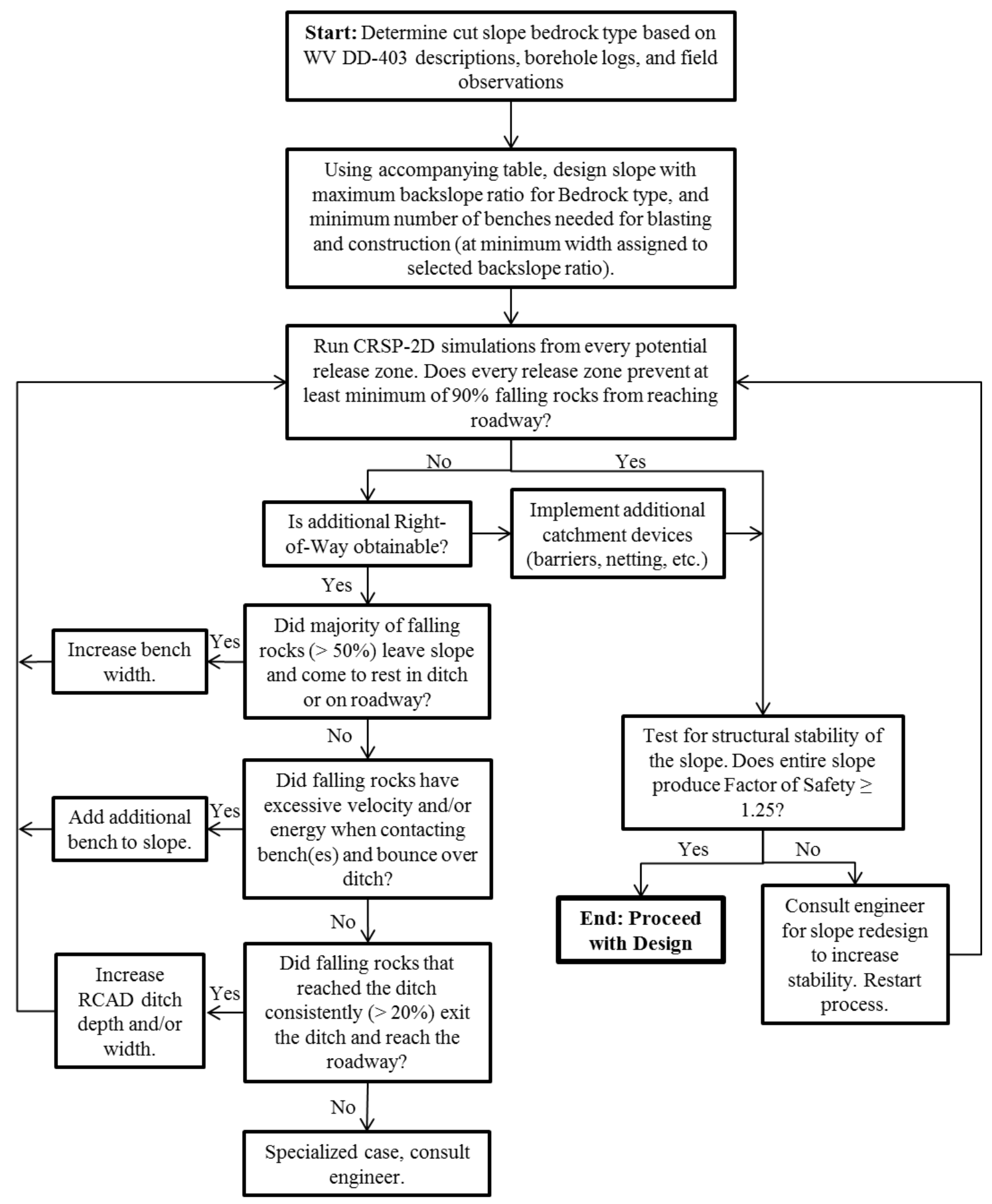

Figure 4.17 Rock cut slope design flow chart for use with WV DD-403 guidelines 


\section{REVIEW OF NUMERICAL MODELING}

While rockfall simulation software, such as CRSP, depicts the effects of falling rock, additional software is needed to determine the likelihood and location of the initiation of rockfall. One approach to this is the use of numerical modeling, such as the finite element method, to determine the stability of the entire slope and any slip surfaces where rockfall initiation is likely. Numerical modeling computer software allows the user to determine the stability Factor of Safety of a given slope using only the geometry and material properties. Numerical modeling computer software was the stability tool selected for this research as it combines the advanced capabilities of Finite Element Method (see Section 2.6.2.1) with the realistic data associated with the numerical modeling. Coupling this modeling with rockfall simulation computer software allows the user to determine the overall feasibility of the highway rock cut slope in question.

The purpose of using numerical modeling software in this research was to determine if the recommended geometric alterations to slope profiles for bench reduction and rockfall mitigation would also create a safe Factor of Safety in terms of structural stability for the slope sections. Factor of safety is defined as the ratio of average strength of a member or property divided by the developed stress of a member or property along a potential failure surface (Das, 2006). A Factor of Safety equal to 1.0 means that the structure in question is on the cusp of failure. Any factor of safety less than 1.0 signifies that a failure has already occurred. While the numerical modeling was not the focus of the conducted research, it was run iteratively with the rockfall simulation modeling as a means of ensuring the overall feasibility of the cut slope in terms of both rockfall mitigation and structural stability. The following sections explain how the numerical modeling process works and any potential limitations.

\subsection{Selection of Modeling Methods}

There are two parts to accurate numerical modeling when dealing with rock slopes: selecting and using the proper geotechnical failure criterion, and then selecting and using the proper analysis method for the modeling software to use. Different earthen materials fail in different ways, and so it is important to identify the failure criterion, or the method used to determine when a model will fail, that most closely depicts the mode of failure expected within the materials being analyzed. In this research, the Hoek-Brown Failure Criterion was selected, as it was developed to identify failures involving rock excavation (Fredlund, 1981). Section 2.4.2.1 discusses the Hoek-Brown Failure Criterion in more detail. Additionally, computer modeling software typically allows for the use of different analysis methods when analyzing the failure data. For this research, General Limit Equilibrium, or GLE, was selected as the analysis method to be used. GLE is described in detail in Section 2.4.2.2.

\subsection{Limitations}

Hoek -Brown failure criterion, coupled with General Limit Equilibrium analysis method, allows for accurate stability analysis of rock cut slopes due to the assessment of non-circular slip surface, but there are still limitations to the results. Figure 5.1 shows an example of given slip surfaces in a rock cut modeled using SVSlope ${ }^{\circledR}$. Notice that the failure plane is very deep below the surface, encompassing the entire bench. Observations of rock cut slopes show that deep failures are very uncommon in highway rock cuts. The majority of failures occurs no greater than three feet deep into the backslope face, and can typically be classified as surface erosion. It can be assumed that the deep failures shown in the SVSlope ${ }^{\circledR}$ analysis depict areas where rockfall is most likely to occur due to these discontinuities, but it should not be assumed that rockfall events as large as the area above the given slip surface will occur. 
Additionally, the Factor of Safety analysis associated with SoilVision SVSlope ${ }^{\circledR}$ is very sensitive to minor changes in geometry and material properties. Thus, to report on the results of any modeling conducted with SVSlope ${ }^{\circledR}$, there must be certainty that all parameters are accurate. If assumptions to any slope parameters must be made, ranges of possible values should be tested to ensure they all produce acceptable Factors of Safety.

Lastly, for an accurate Hoek-Brown analysis, laboratory testing should be conducted on all modeled materials to determine the proper coefficient values. However, in this research the use of borehole log information and research of published values were used since the resources and time were unavailable. Since each rock type can have a range of possible strength values, including unit weight and compressive strength, assumptions from literature can potentially cause inaccuracies in modeling.

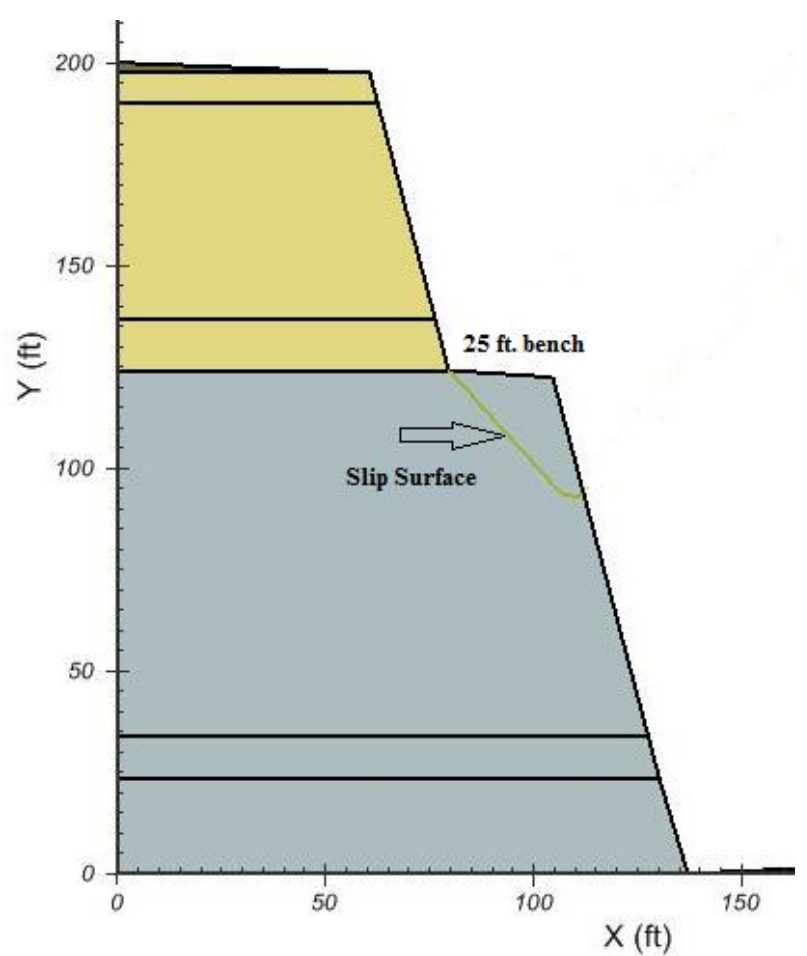

Figure 5.1 Example of a slip surface created with SVSlope ${ }^{\circledR}$ modeling software 


\section{BENCH REMOVAL STUDY}

While it was shown in Section 4.4 that the current rock cut slope design practices used by the West Virginia DOT are adequate with slight modifications, it has been undetermined if there is a better methodology for rock cut slope design that is safer, more stable, and more cost efficient. The objective of this study was to determine if a reduction of benches on highway rock cut slopes is a feasible and beneficial alternative to current benching methods. Two computer modeling programs were used in an iterative process to determine the feasibility of the models: SoilVision SVSlope ${ }^{\circledR}$ and Colorado Rockfall Simulation Program Version 4.0. See Sections 2.4.2 and 5 for a discussion on SVSlope ${ }^{\circledR}$ and why it was used in this study.

This study was conducted concurrently with a similar bench reduction feasibility study using CRSP-3D as the rockfall simulation program, conducted by Pentz (2014). This thesis focuses on the CRSP 2-D analysis and is therefore fundamentally different than the CRSP-3D analysis performed by Pentz (2014). Further research project collaboration was made with Kulbacki (2014) and entailed expanding the slope stability analysis of project study areas using the CRSP3D analysis. The reader is directed to Kulbacki (2014) for background information concerning slope stability analysis of the field study sites evaluated for the WV Research Project No. 283.

\subsection{Rationale for Bench Removal}

Benches on highway rock cut slopes serve many purposes: ease of access for construction blasting crew and other construction and maintenance personnel, reduction of erosion and undercutting between strata layers with differing hardness, and occasionally for on-slope rockfall mitigation. If benches are constructed with a primary purpose of rockfall retention, they are typically placed at equal and consistent spacing up the height of the slope. This is the case with the WVDOT design directives (WV DD-403), which states to never exceed 70 foot spacing between benches and to typically install benches using the equation (WVDOT, 2006):

Space Between Benches $=($ Bench Width $) * 2.5$

Equation 6.1

While these are just recommendations, they were a common observation during field visits and appear to be regularly followed within the state where the lithology allows.

Benches can also have negative effects. As seen in Section 4.4.4, infilling of benches can turn benches into launching features for falling rocks due to their limited catchment area and inaccessibility for proper cleaning. This creates increased rockfall runout, which in turn increases roadway user hazard. As mentioned in Section 2.4, it is for these reasons that many state transportation agencies disagree with using benches as a rockfall mitigation technique. By removing this function, and only focusing on installing benches where necessary for erosion control and construction access, the average number of benches on a tall rock cut slope can be greatly reduced. Potentially, a reduction in benches can reduce excavation and maintenance costs and improve slope stability if constructed properly. However, without the proper testing, it is unsure if these theories are accurate.

\subsection{Introduction to Case Studies}

Two case studies were conducted on highway rock cut slopes in West Virginia, one involving Type 1 Bedrock and one involving Type 3 Bedrock (see Section 2.2). The slope section in Type 1 Bedrock (Compressive strength $=8000+$ psi) was selected to determine if slopes made up primarily of competent rock strata need additional benching for increased slope stability and rockfall catchment, or if only construction access benches need to be designed and implemented. This rock type was selected based on criteria from the WVDOH RP-283 and is assessed in analysis performed by Pentz (2014) and Kulbacki (2014). The slope section with Type 3 
Bedrock (Compressive strength $=1000-4000$ psi) was selected to determine if current design methods of closely spaced ( $\leq 50 \mathrm{ft}$. backslopes) and wide benches do actually increase stability and rockfall catchment in weaker strata, or if reducing the number of benches on the slope is more effective.

\subsubsection{Type 1 Bedrock Case Study Site Description}

U.S. Route 48, also known as Corridor H, in central and northeastern West Virginia is a fourlane highway that will connect Interstate 79 in Weston, WV to Interstate 81 in Strasburg, VA upon completion (see Figure 6.1a). The portion located in West Virginia cuts through very mountainous terrain, thus exposing many tall rock cut slopes. The geology of the eastern portion of West Virginia is made up predominately of sandstone and limestone, two competent bedrock types that may potentially allow for continuous slope faces. The rock cut slope section selected on this highway for a bench removal case study was located next to the eastbound lane of Rt. 48 on a 5 year old portion of highway between Scherr and Moorefield, WV (see Figure 6.1b). It had an overall as-built height of 207 feet, and a total of 6 geotechnical benches. Due to the blockiness of the sandstone layers, there were small accumulations measuring 1-2 ft. in diameter of fallen rocks on all of the benches and the catchment area at the toe-of-slope, but overall the slope appeared stable and vegetation had overtaken the face, reducing further erosion (see Figure 6.2). It appeared that a large portion of the benches on this section of slope served as on-slope rockfall mitigation in addition to construction access. The field observations for this field site road segment were used as the base analysis location for the WVDOH RP283 research project and correlate with Pentz (2014) and Kulbacki (2014) for comparative analysis. Selected rock material values and slope proportion parameters used for stability are accurate for this site (personal communication, April 30, 2014).

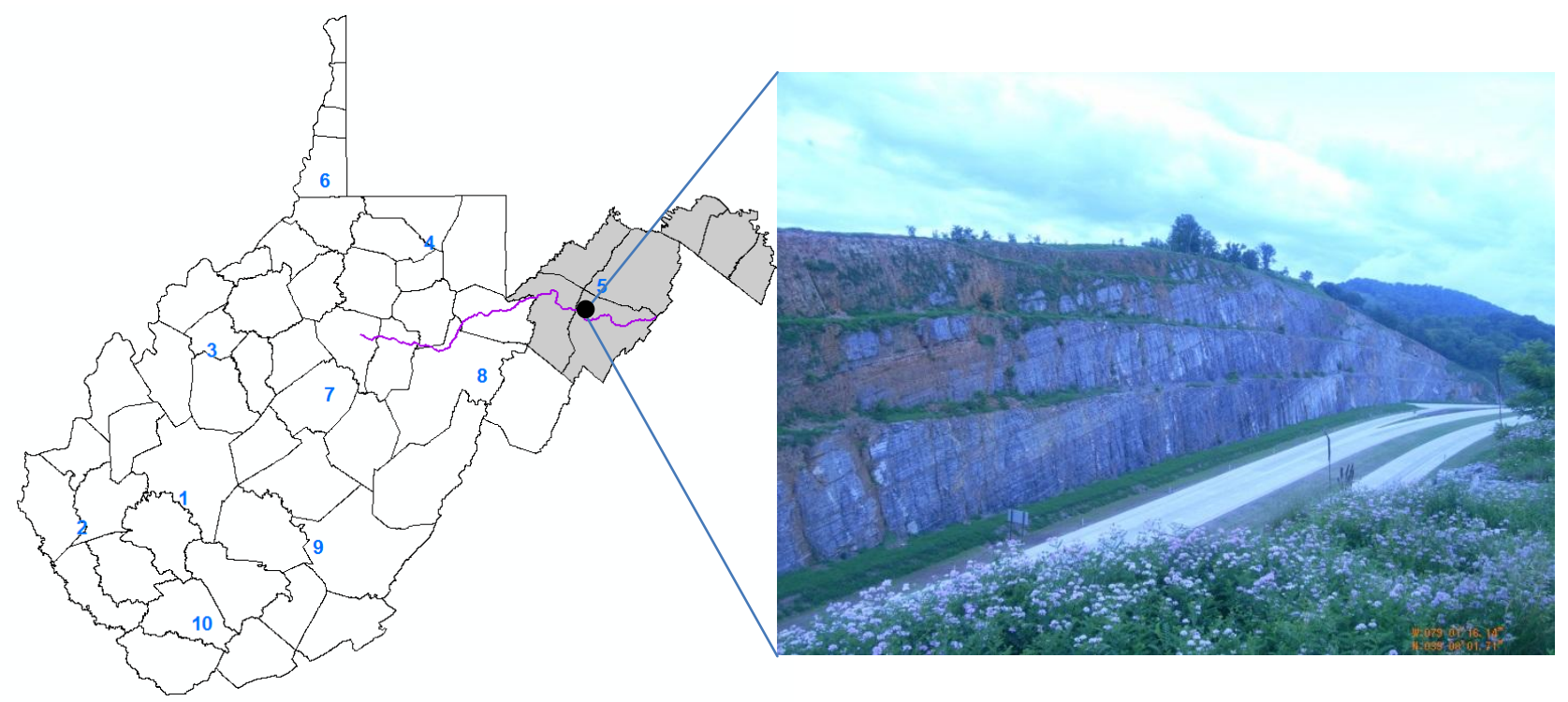

Figure 6.1 Slope Section of US Rt. 48 (Corridor H) in WVDOT District 5, Grant Co., WV 


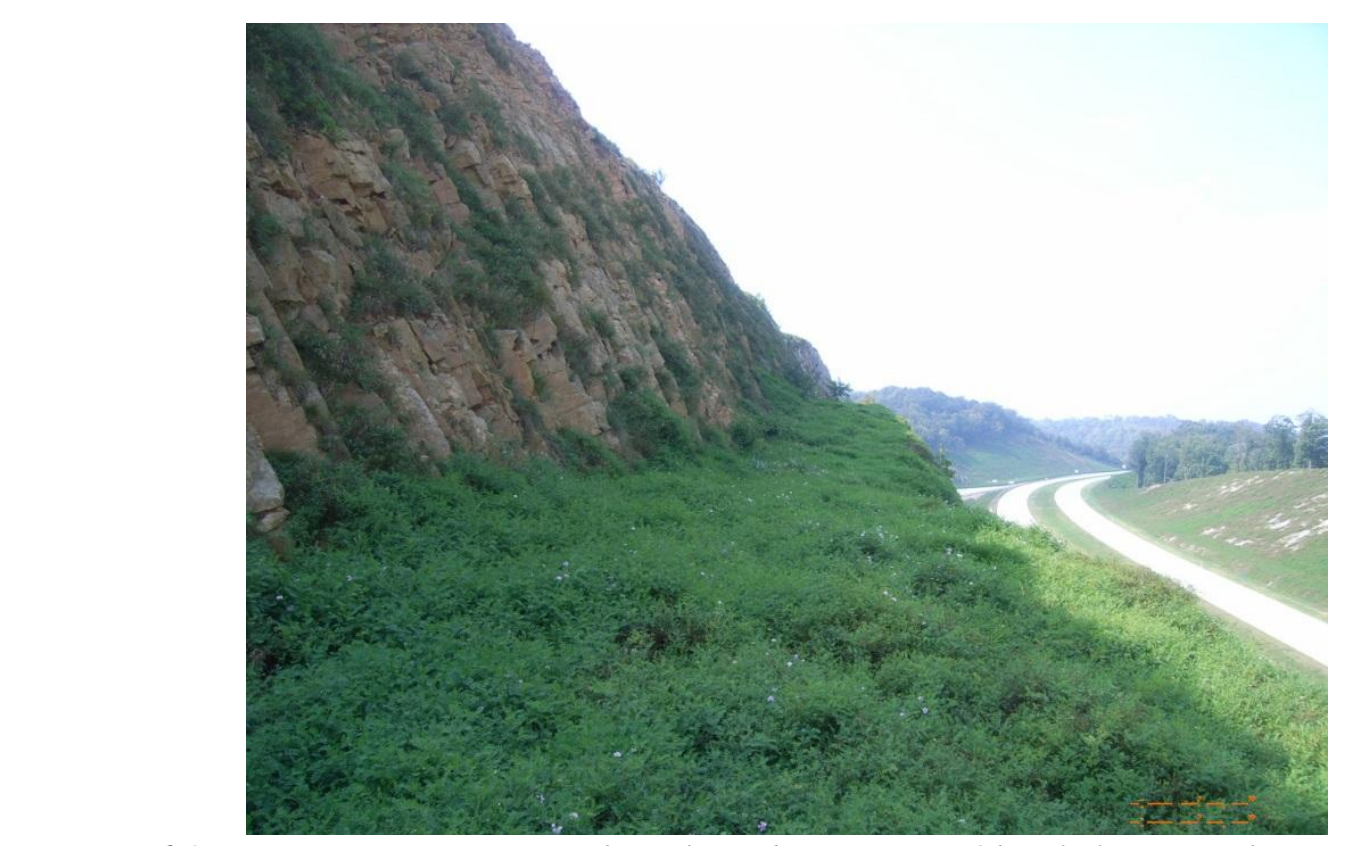

Figure 6.2 Vegetative cover on bench and portions of backslope on the US Rt. 48 Cut Slope Section

\subsubsection{Type 3 Bedrock Case Study Site Description}

U.S. Route 121, also known as the Coalfields Expressway, in southern West Virginia is a fourlane highway that will connect Interstates 64 and 77 to Route 23 in Virginia upon completion (see Figure 6.3a). A large portion of the highway cuts through the lower Allegheny Mountains, exposing alternating layers of sandstone and weak shales/coals. The shale layers are typically very large, weak, and erodible. As these more friable layers erode away and undercut, the blockier sandstone layers located above them break free and create a rockfall hazard. The rock cut slope section selected on this highway for a bench removal case study was located next to the southbound lane of Rt. 121 on a newly constructed an unpaved section between Sophia and Mullens, WV (see Figure 6.3b). It had an overall as-built height of 358 feet, and a total of six geotechnical benches. Even though this particular slope had only been completed for approximately two years, there were already noticeable large rocks that had fallen onto benches and into the bottom catchment area (See Figure 6.4). It could be inferred that without proper remediation efforts, this slope as it was designed could produce large numbers of rockfall events and be very hazardous to roadway users in the future. An RHRS study was conducted on this site, and it received an overall score of 444, the highest of the 6 RHRS sites sampled during the study. Field observations for this site are referenced from Kulbacki (2014). 


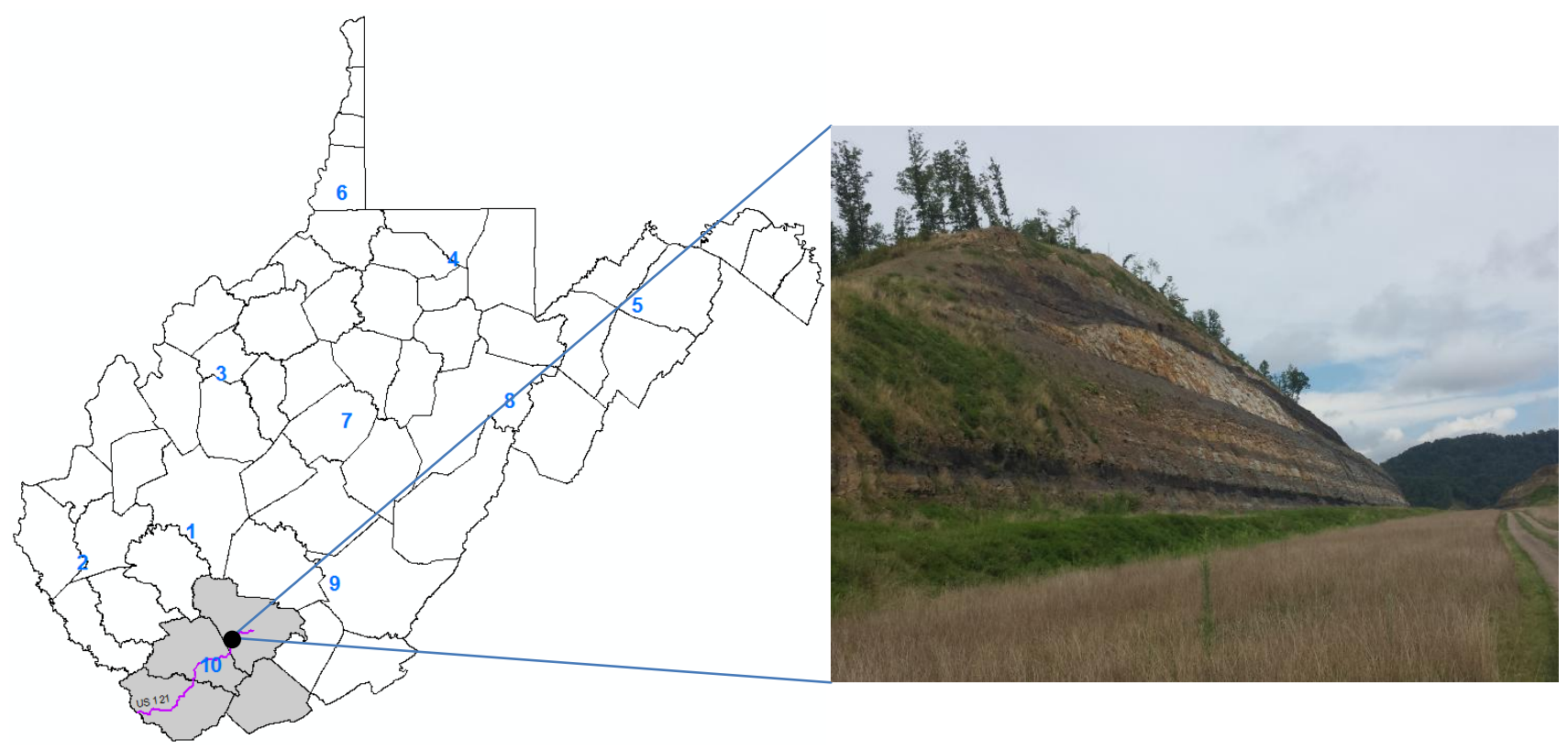

Figure 6.3 Slope Section of US Route 121 (Coalfields Expressway) in WVDOT District 10, Raleigh Co., $W V$.

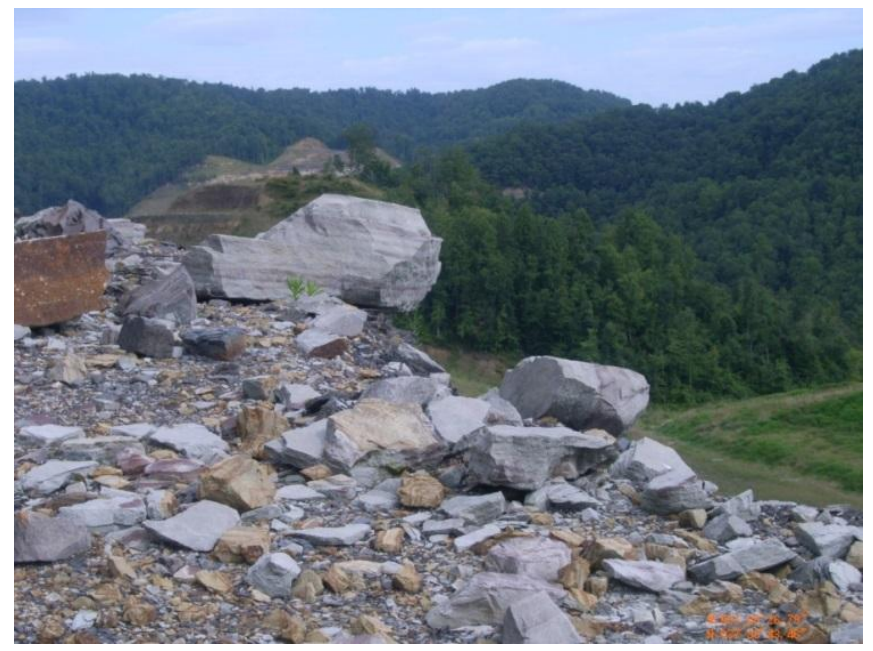

Figure 6.4 Accumulation of large rocks on a bench on the US Rt. 121 Cut Slope Section

\subsection{Field Data Collection Method}

After the sites were selected, the next step was to determine the data needing to be collected to properly conduct the study. The two components to the study are CRSP-2D and SoilVision SVSlope ${ }^{\circledR}$, so the data collection criteria were broken down into these two categories:

- CRSP-2D

O Slope geometry (height and width only)

- Rock strata geometry (geometric changes between hard and soft rock types)

○ Rock strata classification (hard bedrock or soft bedrock)

- Unit weight of rock strata

- Ditch and shoulder material type(s)

$\circ$ Location(s) of rockfall initiation 
- Accumulation of debris on benches

$\circ$ Presence and location of vegetation

\section{- SoilVision SVSlope ${ }^{\circledR}$}

○ Slope geometry

○ Rock strata geometry

- Rock strata strengths and unit weights

- Observations of blasting practices (over- or under-blasted)

For both case study sections, US Route 121 and US Route 48, construction plans and borehole logs were provided for comparison with field measurements and observations. The field observed measurements varied rather greatly from the construction plan geometry (perhaps due to issues encountered during the construction process), and the field observed measurements were selected as the modeled values due to the desire to model the actual constructed slopes. Table 6.1 compares the geometric values for the construction plans versus the field observed measurements for both case study sites.

For both sites, the construction plan geometry closely resembles the recommendations put forth by the WVDOT in Design Directive 403. In the construction plans for the cut slope on US Route 121, backslope angles averaged 3/4:1 and backslope heights averaged 50 feet, which both fall within recommended ranges in WV DD-403. However, the as-built backslope angles averaged closer to $1 / 2: 1$ with backslope heights averaging 62 feet, which are only recommended for more competent cut slopes. However, the as-built benches averaged about 10 feet wider than the construction plans designed for.

Less drastic differences were noticed with the cut slope on US Route 48, with both the construction plan geometry and the field measurements showing an average backslope angle of approximately 1/4:1 and average backslope heights of 50 vertical feet. According to WV DD403, these backslope heights could be higher, which would potentially save on excavation costs. 
Table 6.1 Comparison of Construction Plan Geometry and Field Measurements of Two Case Study Sites in West Virginia

\begin{tabular}{|c|c|c|c|c|c|c|c|c|}
\hline \multirow{3}{*}{$\begin{array}{l}\text { Backslope } \\
\text { or Bench \# }\end{array}$} & \multicolumn{4}{|c|}{ US Route 121 (Coalfields Expressway) } & \multicolumn{4}{|c|}{ US Route 48 (Corridor H) } \\
\hline & \multicolumn{2}{|c|}{ Construction Plans } & \multicolumn{2}{|c|}{ Field Measurements } & \multicolumn{2}{|c|}{ Construction Plans } & \multicolumn{2}{|c|}{ Field Measurements } \\
\hline & $\begin{array}{l}\text { Height/ Width } \\
\text { (ft.) }\end{array}$ & Angle & $\begin{array}{l}\text { Height/ Width } \\
\text { (ft.) }\end{array}$ & Angle & $\begin{array}{l}\text { Height/ } \\
\text { Width (ft.) }\end{array}$ & Angle & $\begin{array}{l}\text { Height/ Width } \\
\text { (ft.) }\end{array}$ & Angle \\
\hline Backslope 1 & 5.0 & $45^{\circ}$ & 5.0 & $45^{\circ}$ & 2.68 & $75.2^{\circ}$ & 4.0 & $65^{\circ}$ \\
\hline Bench 1 & 20.0 & $3.8^{\circ}$ & 37.0 & $3.8^{\circ}$ & 20.0 & $3.8^{\circ}$ & 19.0 & $3.8^{\circ}$ \\
\hline Backslope 2 & 49.0 & $53.1^{\circ}$ & 57.4 & $64.1^{\circ}$ & 50.0 & $75.5^{\circ}$ & 52.0 & $75^{\circ}$ \\
\hline Bench 2 & 20.0 & $3.8^{\circ}$ & 30.0 & $3.8^{\circ}$ & 19.7 & $3.8^{\circ}$ & 14.0 & $3.8^{\circ}$ \\
\hline Backslope 3 & 49.0 & $53.1^{\circ}$ & 59.8 & $65.0^{\circ}$ & 50.0 & $75.5^{\circ}$ & 50.0 & $75^{\circ}$ \\
\hline Bench 3 & 20.0 & $3.8^{\circ}$ & 30.0 & $3.8^{\circ}$ & 20.0 & $3.8^{\circ}$ & 22.0 & $3.8^{\circ}$ \\
\hline Backslope 4 & 49.0 & $53.1^{\circ}$ & 53.6 & $70.0^{\circ}$ & 50.0 & $75.5^{\circ}$ & 56.0 & $70^{\circ}$ \\
\hline Bench 4 & 20.0 & $3.8^{\circ}$ & 26.0 & $3.8^{\circ}$ & 20.0 & $3.8^{\circ}$ & 21.0 & $3.8^{\circ}$ \\
\hline Backslope 5 & 49.0 & $53.1^{\circ}$ & 54.4 & $65.0^{\circ}$ & 33.58 & $61.3^{\circ}$ & 35.5 & $65^{\circ}$ \\
\hline Bench 5 & 20.0 & $3.8^{\circ}$ & 20.0 & $3.8^{\circ}$ & 15.0 & $3.8^{\circ}$ & Un-accessible & $3.8^{\circ}$ \\
\hline Backslope 6 & 49.0 & $53.1^{\circ}$ & 56.2 & $65.0^{\circ}$ & 7.42 & $\begin{array}{l}\text { Over- } \\
\text { burden }\end{array}$ & Un-accessible & $\mathrm{n} / \mathrm{a}$ \\
\hline Bench 6 & 20.0 & $3.8^{\circ}$ & 21.0 & $3.8^{\circ}$ & - & - & - & - \\
\hline Backslope 7 & 49.0 & $53.1^{\circ}$ & 25.0 & $54.8^{\circ}$ & - & - & - & - \\
\hline
\end{tabular}

The stratigraphy of the slopes was found using a combination of the borehole logs from the construction plans and the field measurements. While borehole logs provide accuracy that field technicians cannot achieve, the boreholes are often not drilled in the same location as the case study and thus are misaligned. Using field measurements to find an estimated starting location on the slope that lined up with borehole log information provided the most accurate slope stratigraphy for the case studies. Tabular summaries of the borehole log information for each case study site can be found in later sections of this report.

Notes were also taken during the field visits to both sites in respect to the additional information needed to accurately model the slope sites in both CRSP-2D and SoilVision SVSlope ${ }^{\circledR}$ (see the beginning of this section). 


\subsection{Bench Removal Methodology and Results}

Initially, the as-built slope section was modeled in both programs. SVSlope ${ }^{\circledR}$ determined the structural stability Factor of Safety for the slope section by evaluating the model using the GLE calculation method described in Section 5.1. If the Factor of Safety for the entire slope was at or above FOS $=1.25$, the slope was considered stable. A Factor of Safety of 1.25 is the absolute minimum requirement for construction set forth by the WVDOT (WVDOH, 2006). For higher ranking roads (arterials), WVDOT states that the Factor of Safety should be a minimum of 1.50. For this research, $\mathrm{FS}=1.25$ was considered passing.

Then, CRSP-2D determined if the current slope geometry is adequate to safely retain rockfall and reduce rockfall runout onto the roadway. This was conducted simultaneously with the SVSlope ${ }^{\circledR}$ modeling. A minimum of $90 \%$ of the falling rocks were required to be retained before reaching the roadway during simulation for the slope section to be considered safe. Rockfall release zones were chosen as the top of every backslope to ensure comprehensive analysis, and the minimum retention percentage had to be met for all release zones. After analyzing the results, the concurrent bench reduction trials could then have one of the following two objectives:

1. If the as-built slope is structurally stable and safely retains rockfall, the objective for bench reduction is to reduce excavation costs while retaining a stable and safe slope. While increases in Factor of Safety and rockfall retention percentage are positive outcomes, they are not necessary if the initial slope is adequate.

2. If the as-built slope is either not structurally stable, does not retain an adequate amount of rockfall from the roadway, or both, the objective for the bench reduction trials is to create a slope that is both stable and safe. If removing benches has a negative effect, the addition or widening of benches may also be tested in trials. Safety always takes priority over cost reduction, thus excavation cost reduction is not an objective in this case.

Since many slope characteristics were assumed or generalized for this research project, the Factor of Safety results and rockfall retention results may not be accurate compared to actual field conditions. For this reason, the results of these case studies should only be considered examples of how the analysis process works. For a more accurate bench reduction study, material testing should be conducted and slope geometry should be measured with LiDar to ensure precision.

\subsubsection{US Route 48 Case Study}

Table 6.2 displays the borehole log information, as provided by WVDOT, of the slope section on US Route 48, along with the CRSP-2D coefficient designation for each material type. 


Table 6.2 Geometric Information for US Route 48 Case Study Slope Section
\begin{tabular}{|c|c|c|l|}
\hline $\begin{array}{c}\text { Vertical Depth } \\
\text { from Initial } \\
\text { Grade (ft.) }\end{array}$ & $\begin{array}{c}\text { Initial Vertical } \\
\text { Height from Toe } \\
\text { Grade (ft.) }\end{array}$ & Material Type & \multicolumn{1}{|c|}{ CRSP Designation } \\
\hline $\mathbf{0}-\mathbf{2 . 4 8}$ & 200.0 & Soil - Silty Sand & Loose Soil \\
\hline $\mathbf{2 . 4 8}-\mathbf{1 0 . 0}$ & 197.52 & Sandstone & Hard Bedrock $\left(\mathrm{R}_{\mathrm{n}}=0.30\right)$ \\
\hline $\mathbf{1 0 . 0}-\mathbf{6 3 . 4 4}$ & 190.0 & Sandstone & Hard Bedrock $\left(\mathrm{R}_{\mathrm{n}}=0.30\right)$ \\
\hline $\mathbf{6 3 . 4 4}-\mathbf{7 6 . 0}$ & 136.56 & Sandstone & Hard Bedrock $\left(\mathrm{R}_{\mathrm{n}}=0.30\right)$ \\
\hline $\mathbf{7 6 . 0}-\mathbf{1 6 5 . 5 2}$ & 124.0 & Limestone & Hard Bedrock $\left(\mathrm{R}_{\mathrm{n}}=0.31\right)$ \\
\hline $\mathbf{1 6 5 . 5 2}-\mathbf{1 7 6 . 0}$ & 34.48 & Limestone & Hard Bedrock $\left(\mathrm{R}_{\mathrm{n}}=0.31\right)$ \\
\hline $\mathbf{1 7 6 . 0}-\mathbf{2 0 0 . 0}$ & 24.0 & Limestone & Hard Bedrock $\left(\mathrm{R}_{\mathrm{n}}=0.31\right)$ \\
\hline
\end{tabular}

The following subsections show the results from both computer modeling procedures: SoilVision SVSlope ${ }^{\circledR}$ stability analysis, and Colorado Rockfall Simulation Program Version 4.0 analysis. Additional observations and recommendations can also be found in these sections.

\subsubsection{As-built Slope Feasibility Case Study}

The initial modeling tests were conducted to determine if the in situ as-built slope section is stable and safe as is. The geometric parameters were taken from the field measurements and converted into $\mathrm{X}$ and $\mathrm{Y}$ coordinates for each modeling program. Table 6.1 (in Section 6.3), in concurrence with Figure 6.5, displays the backslope heights and bench widths of the as-built slope section on US Route 48. 


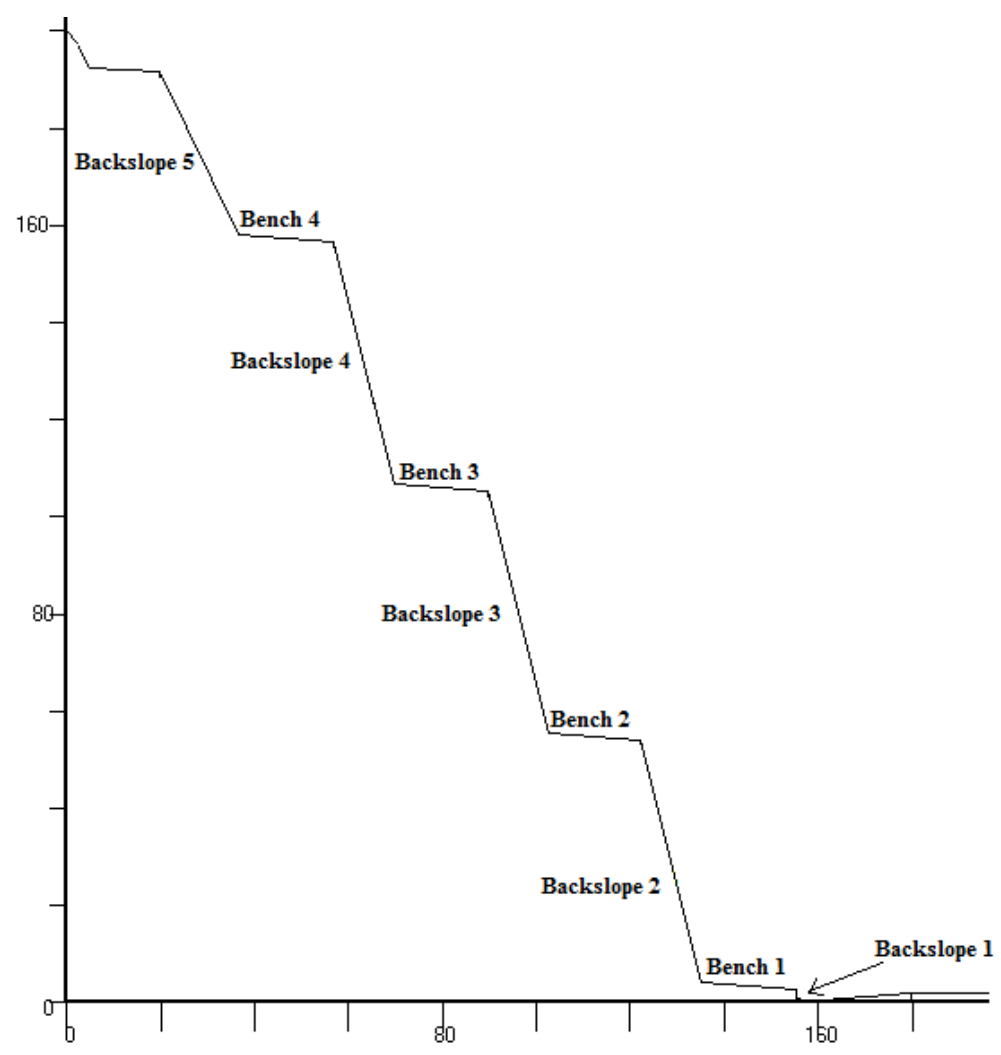

Figure 6.5 Two-Dimensional Profile of As-built Slope Section of US Route 48

\subsection{SoilVision SVSlope ${ }^{\circledR}$ Results}

Results from the stability analysis in SVSlope ${ }^{\circledR}$ are presented in Figure 6.6. The material inputs for the slope section can be seen in the "Materials" key at the top of the figure. The small overburden layer at the top of the slope was input as Bedrock (instead of soil) so failure planes would not occur in this layer. This was done so only rock material layers would be analyzed. The inputs for the Sandstone and Limestone layers, including unit weight, Unconfined Compressive Strength, Disturbance Factor (D), and Hoek Brown constants $m i, m b$, and $s$ (See Section 5.1) can also be seen in the Materials key. To calculate the constants $m b$ and $s$ ( $m i$ is a known value), the Geological Strength Index (GSI) is also needed for each rock material type. Kulbacki (2014) suggested using a value of 23 for the GSI, as it represents the minimum value for blocky, hard material (Sjöberg, 1997). Average values for Unconfined Compressive Strength (UCS) and Unit Weight were taken from literature, as suggested by Kulbacki (2014) (Zhao, 2010). Table 6.3 displays the selected values for Unconfined Compressive Strength (UCS), Geological Strength Index (GSI), the Hoek Brown constants, and are the same as used by Kulbacki (2014) for comparative purposes. The unit weights for each rock type used in the case studies can be found in the table, selected from published literature (Zhao, 2010). Unit weight values were agreed upon by Pentz (personal communication, June 30, 2014). Additionally, the Disturbance Factor, which ranges from 0.6 for good blasting to 1.0 for poor blasting, was given a value of 0.7 (Hoek, 2007). This is approximate for the blasting conditions that were observed in the field, in which proper techniques appeared to be used and minimal overblasting occurred.

Due to shared field observations from this slope site on Corridor $\mathrm{H}$ and similar modeling parameters, both Kulbacki (2014) and Pentz (2014) display similar models as analyzed Figure 6.6. 
Table 6.3 Selected Values for Various Parameters needed for Numerical Modeling with Hoek Brown Failure Criteria

\begin{tabular}{|c|c|c|c|c|c|c|}
\hline \multirow{2}{*}{$\begin{array}{c}\text { Material } \\
\text { Type }\end{array}$} & \multirow{2}{*}{$\begin{array}{l}\text { Average Unit } \\
\text { Weight }\left(\mathrm{lb} / \mathrm{ft}^{3}\right)\end{array}$} & \multirow{2}{*}{$\begin{array}{c}\text { Geological } \\
\text { Strength Index }\end{array}$} & \multicolumn{3}{|c|}{ Hoek Brown constants } & \multirow{2}{*}{$\begin{array}{c}\text { Unconfined } \\
\text { Compressive } \\
\text { Strength }\left(\mathrm{lb} / \mathrm{ft}^{2}\right)\end{array}$} \\
\hline & & & $m i$ & $m b$ & $s$ & \\
\hline Siltstone & 165 & 23 & 9 & 0.037 & $\begin{array}{c}2.67 \mathrm{x} \\
10^{-6}\end{array}$ & $1,148,700$ \\
\hline Sandstone & 150 & 23 & 5 & 0.02 & $\begin{array}{c}2.67 \mathrm{x} \\
10^{-6}\end{array}$ & $1,984,100$ \\
\hline Limestone & 160 & 23 & 4 & 0.016 & $\begin{array}{c}2.67 \mathrm{x} \\
10^{-6}\end{array}$ & $2,924,000$ \\
\hline
\end{tabular}

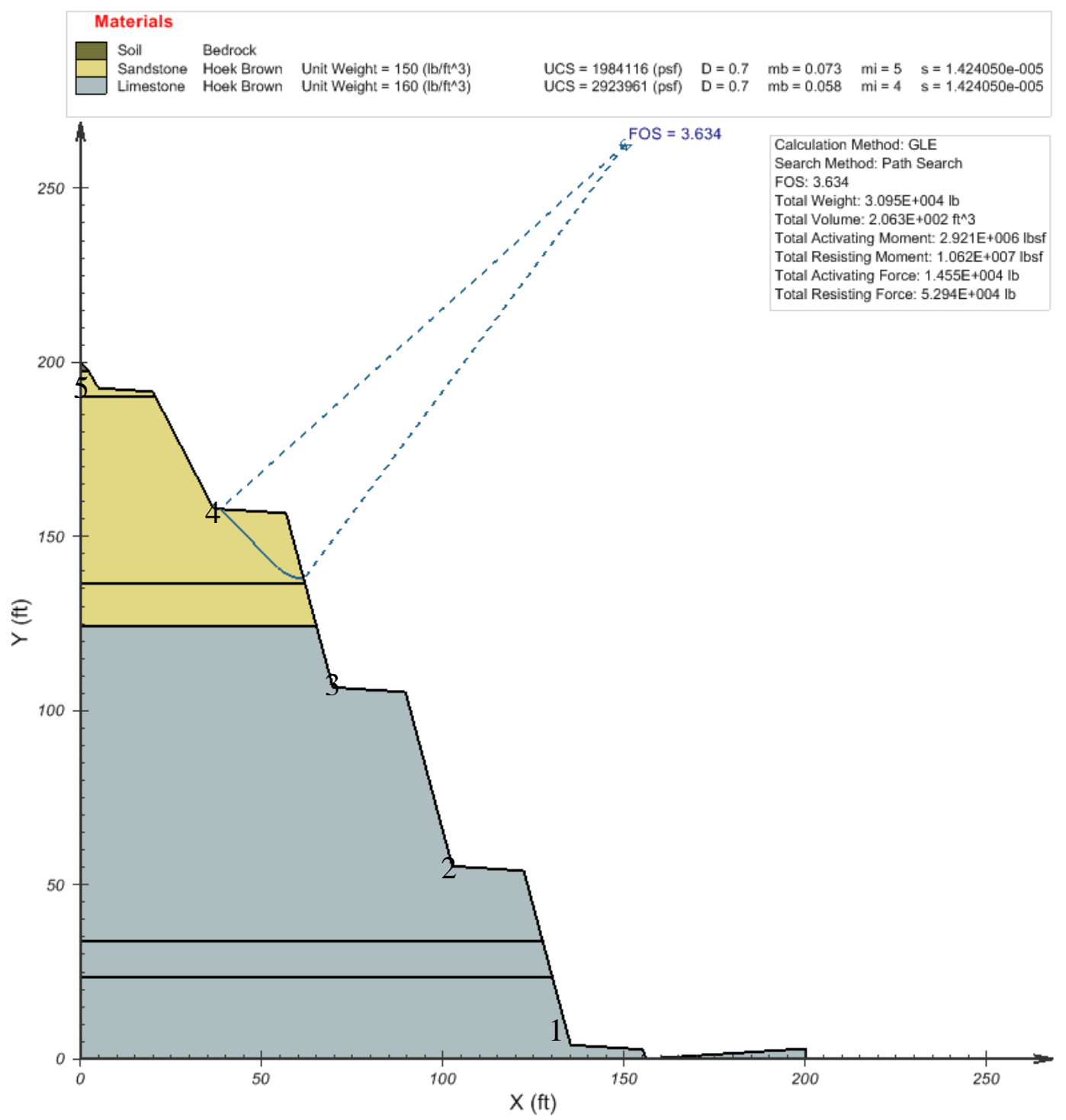

Figure 6.6 Two-Dimensional Slope Section Profile and Stability Analysis results for Asbuilt slope section on US Route 48. 
The lowest Factor of Safety for the slope section was found to be 3.63, and occurred between Bench 4 and Backslope 4 . This slope is considered highly stable with these results. Thus, it can be inferred that this slope section was properly designed by engineers to be structurally stable.

\subsection{CRSP-2D Simulations Results}

It can be seen in Figure 6.2 that the benches at this slope site were highly vegetated. This was a common scenario on rock cut slopes on Corridor $\mathrm{H}$. As mentioned in the calibration section (Section 4.3), the tangential coefficient in CRSP-2D reduces in value when dealing with high vegetation. Thus, for this slope section, backslopes were given a value of $R_{t}=0.92$, but the tangential coefficient for all benches were reduced to a value of $R_{t}=0.91$. Additionally, some assumptions were made that had not been confirmed with CRSP calibration. These include:

- Increased the normal coefficient value for limestone layers to $R_{n}=0.31$. This is done because limestone is known to be much harder than sandstone, and with the case study site having a distinctive transition between the two material types, the difference should be displayed in the modeling.

- Falling rocks simulated from the limestone layer were given a unit weight of $160 \mathrm{lb} / \mathrm{ft}^{3}$, while falling rocks simulated from the sandstone layer were kept at $150 \mathrm{lb} / \mathrm{ft}^{3}$. This denser weight was given due to review of published values (Zhao, 2010).

Figure 6.7 depicts the as-built slope section after being modeled in CRSP-2D. Note that the cells create vertical "layers" in this program, which is an inaccurately appearing model compared to the actual stratigraphy. This does not affect the rockfall simulation results, as only the surface of the model is considered, and the surface is accurately depicted. 


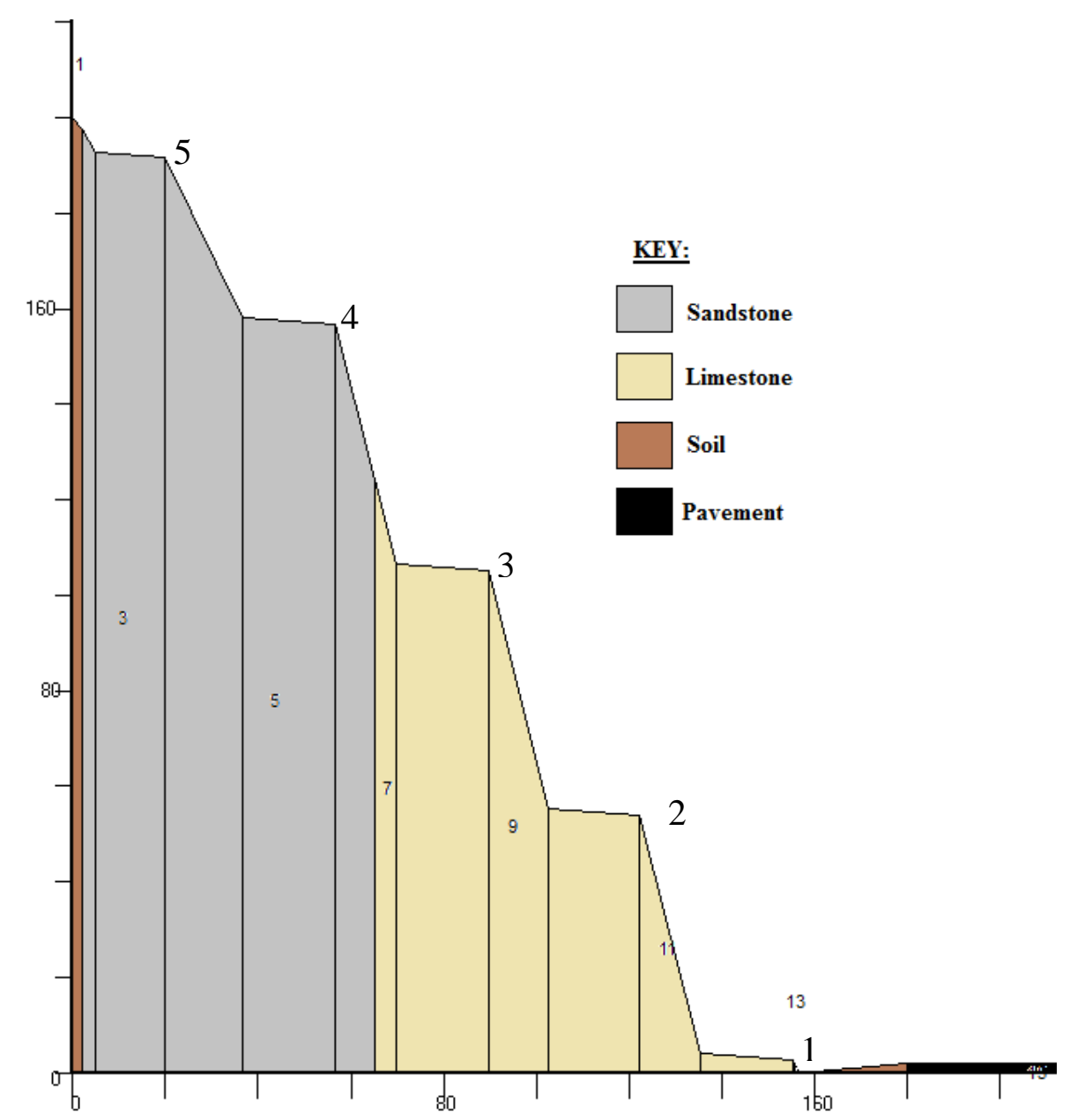

Figure 6.7 Two-Dimensional Slope Section Profile from As-built slope section of US Route 48 modeled in CRSP-2D

Even though the entire slope section received a high Factor of Safety for stability, slope face failures will still occur, creating rockfall events. Thus, the slope was still modeled in CRSP-2D, and multiple rockfall simulations were run, each with different release zones. The objective was to determine the worst case release zone for rockfall runout, and to confirm that the slope retains at least $90 \%$ of the rockfall released from this zone. The results of these simulations can be seen in Table 6.4.

While the majority of the rockfall release zones produced safe retention results, rocks released from the top of Cell 11, or the top of Backslope 2, reached the roadway shoulder $25 \%$ of the time. This higher number is due to there only being one catchment bench below this release zone before the roadway. See Appendix V for a visual representation of the rockfall trajectory. Recommendations to remediate this issue would be to remove the lowest bench (Bench 1) and replace it with an RCAD ditch, or extend the lower bench if additional Right-of-Way is obtainable. 
Table 6.4 CRSP-2D Simulation Runs with Various Rockfall Release Zones on As-built Case Study Slope on US Route 48

\begin{tabular}{|c|c|c|c|c|c|}
\hline $\begin{array}{l}\text { Rockfall } \\
\text { Release } \\
\text { Zone } \\
\text { (Cell \#'s) }\end{array}$ & $\begin{array}{l}\text { Rockfall Release } \\
\text { Zone Description }\end{array}$ & $\begin{array}{l}\text { Rockfall Material } \\
\text { Type and Density }\end{array}$ & $\begin{array}{l}\text { Rockfall } \\
\text { Diameter } \\
\quad \text { (ft.) }\end{array}$ & $\begin{array}{c}\text { Percentage } \\
\text { Retained } \\
\text { Before } \\
\text { Roadway }\end{array}$ & $\begin{array}{c}\text { Average } \\
\text { Runout passed } \\
\text { Toe of Slope } \\
\text { (ft.) }\end{array}$ \\
\hline 11 & $\begin{array}{c}3 \text { feet @ Top of } \\
\text { Backslope } 2\end{array}$ & $\begin{array}{c}\text { Limestone (Hard } \\
\text { Bedrock), } 160 \mathrm{lb} / \mathrm{ft}^{3}\end{array}$ & 1.0 & $75 \%$ & 19.4 \\
\hline 9 & $\begin{array}{c}3 \text { feet @ Top of } \\
\text { Backslope } 3\end{array}$ & $\begin{array}{l}\text { Limestone (Hard } \\
\text { Bedrock), } 160 \mathrm{lb} / \mathrm{ft}^{3}\end{array}$ & 1.0 & $93 \%$ & 29.1 \\
\hline 9 & $\begin{array}{c}3 \text { feet @ Top of } \\
\text { Backslope } 3\end{array}$ & $\begin{array}{c}\text { Limestone (Hard } \\
\text { Bedrock), } 160 \mathrm{lb} / \mathrm{ft}^{3}\end{array}$ & 1.25 & $92 \%$ & 25.3 \\
\hline 6 & $\begin{array}{l}32.5 \text { feet @ Top of } \\
\text { Backslope } 4\end{array}$ & $\begin{array}{c}\text { Sandstone (Hard } \\
\text { Bedrock), } 150 \mathrm{lb} / \mathrm{ft}^{3}\end{array}$ & 1.0 & $97 \%$ & 21.1 \\
\hline 4 & $\begin{array}{l}33.5 \text { feet consisting } \\
\text { entirely of } \\
\text { Backslope } 5\end{array}$ & $\begin{array}{c}\text { Sandstone (Hard } \\
\text { Bedrock), } 150 \mathrm{lb} / \mathrm{ft}^{3}\end{array}$ & 1.0 & $98 \%$ & 17.6 \\
\hline
\end{tabular}

\subsubsection{Bench Removal Feasibility Case Study Trial 1}

Since the original slope was very stable, the objective of the first bench reduction trial was to observe the effects on stability when only three geotechnical benches are evenly placed along the slope section while keeping the same backslope angles as the original as-built slope. Due to the initial high Factor of Safety, two benches were selected to be removed instead of just one. In an attempt to achieve a safer percentage of rockfall retention, bench widths were increased from 20 feet to 25 feet, and the lowest bench was replaced with a 25 foot wide RCAD ditch. Even with increased bench widths, the entire slope width was 17 feet narrower than the original as-built width for this slope section, which could allow for an even larger RCAD ditch if necessary. This can be seen in Figure 6.8.

\subsection{SoilVision SVSlope ${ }^{\circledR}$ Results}

In this redesign, the benches were modeled around the lithology of the slope section. The central bench was placed at the transition between the sandstone layers and limestone layers. While both of these layers are considered hard bedrock and do not have high erosion rates, undercutting is more likely to occur at the transition between strata. The remaining two benches were placed at the locations of Benches 2 and 5 in the as-built slope. The stability results yielded a large reduction in Factor of Safety, but remained a stable slope with the smallest on-slope Factor of Safety $=1.49$. Figure 6.8 shows the location of the failure plane with the lowest Factor of Safety, which starts in Bench 2 and continues into Backslope 2. 


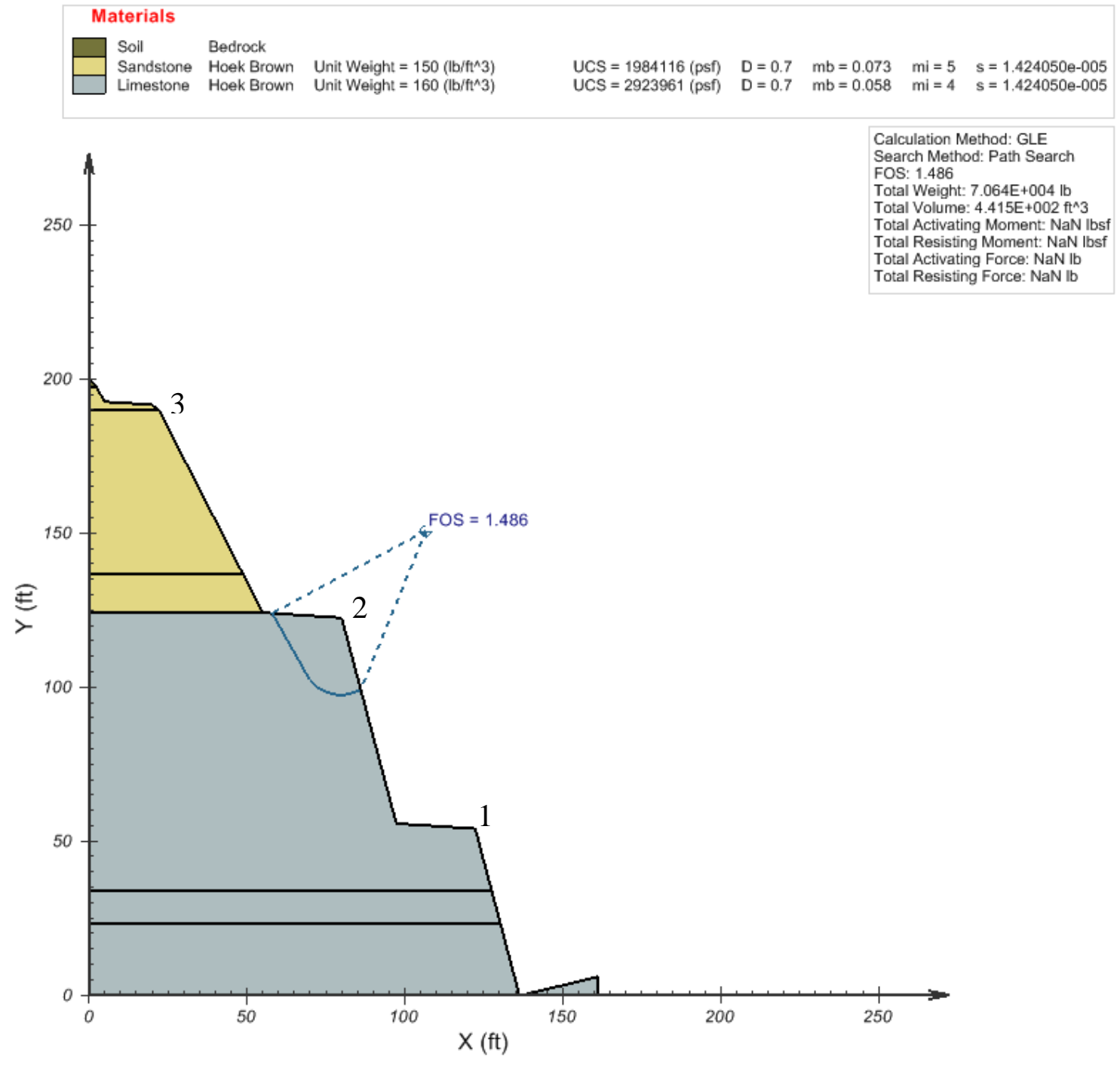

Figure 6.8 Two-Dimensional Slope Section Profile and Stability Analysis results for first bench removal case on US Route 48 slope section.

\subsection{CRSP-2D Simulation Results}

Since the first bench removal case was found to be structurally stable, rockfall simulations were also run on the redesigned slope section. Figure 6.9 shows a comparison of the original as-built slope and the redesigned slope with the reduction in benches. For the CRSP-2D modeling, an RCAD ditch was implemented at the toe of slope, with a one foot flat bottom and a 24 foot back slope to the roadway shoulder. 


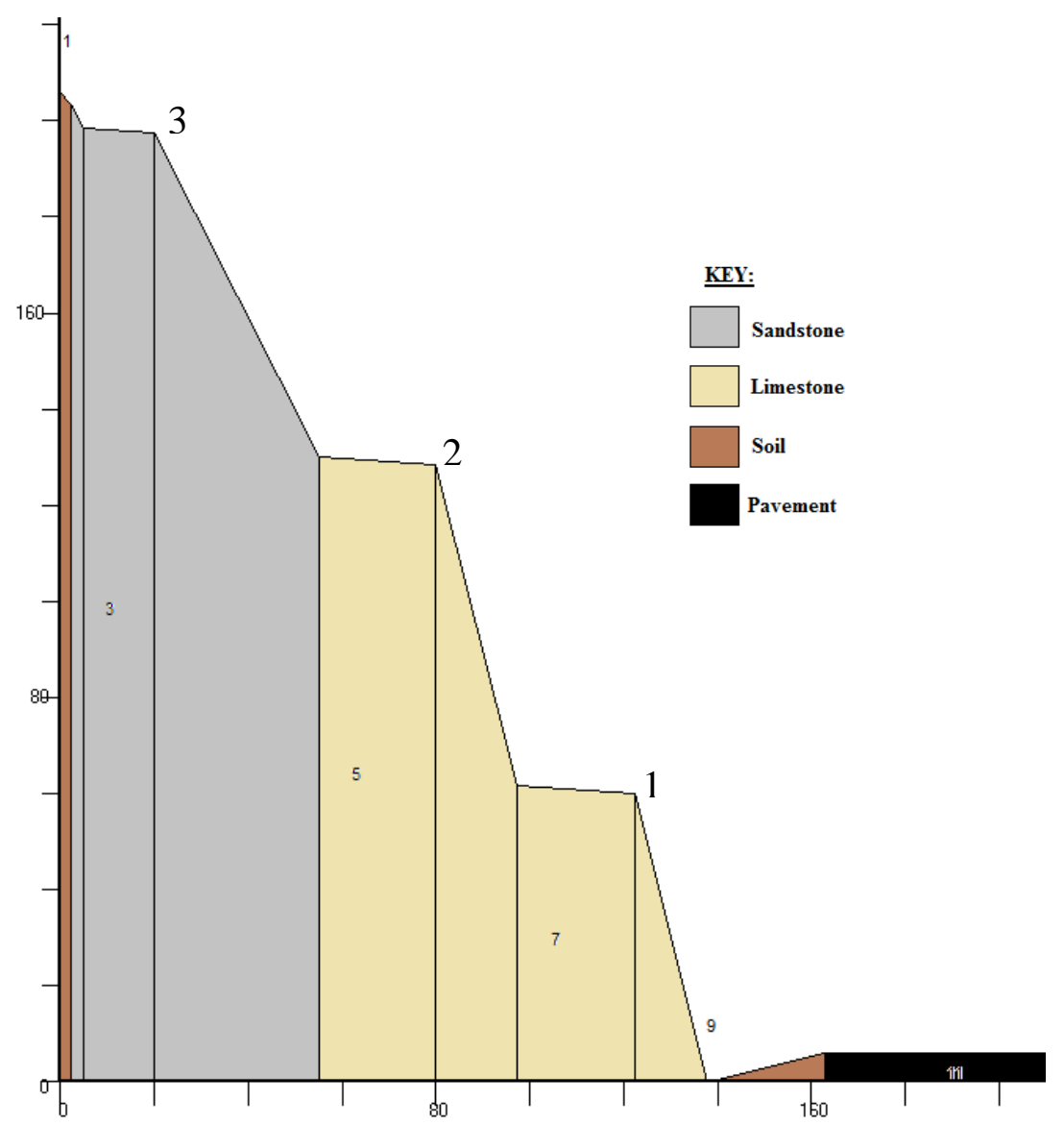

Figure 6.9 Two- Dimensional Slope Section Profile from first bench removal case of slope section of US Route 48 modeled in CRSP-2D

Table 6.5 displays the simulation trial results. As with the as-built slope simulations, different release zones were selected and tested with the objective to determine the worst case release zone, and confirm that the slope retains a safe amount of falling rocks from that section. For this slope geometry, the release zone with the lowest on-slope retention was the top of Backslope 3. Bench 1 and the RCAD ditch were still able to retain $94 \%$ of the rockfall initiated from this release zone prior to it reaching the roadway. Thus, this redesigned slope section with only three benches is considered both stable and safe. 
Table 6.5 CRSP-2D Simulation Runs with Various Rockfall Release Zones on Bench Reduction Trial 1 of US Route 48 Case Study Slope

\begin{tabular}{|c|c|c|c|c|c|}
\hline $\begin{array}{c}\text { Rockfall } \\
\text { Release } \\
\text { Zone } \\
\text { (Cell \#'s) }\end{array}$ & $\begin{array}{l}\text { Rockfall Release } \\
\text { Zone Description }\end{array}$ & $\begin{array}{l}\text { Rockfall Material } \\
\text { Type and Density }\end{array}$ & $\begin{array}{l}\text { Rockfall } \\
\text { Diameter } \\
\text { (ft.) }\end{array}$ & $\begin{array}{c}\text { Percentage } \\
\text { Retained } \\
\text { Before } \\
\text { Roadway }\end{array}$ & $\begin{array}{c}\text { Average } \\
\text { Runout Past } \\
\text { Ditch (ft.) }\end{array}$ \\
\hline 8 & $\begin{array}{c}3 \text { feet @ Top of } \\
\text { Backslope } 1\end{array}$ & $\begin{array}{c}\text { Limestone (Hard } \\
\text { Bedrock), } 160 \mathrm{lb} / \mathrm{ft}^{3}\end{array}$ & 1.0 & $100 \%$ & $\mathrm{n} / \mathrm{a}$ \\
\hline 6 & $\begin{array}{c}3 \text { feet @ Top of } \\
\text { Backslope } 2\end{array}$ & $\begin{array}{l}\text { Limestone (Hard } \\
\text { Bedrock), } 160 \mathrm{lb} / \mathrm{ft}^{3}\end{array}$ & 1.0 & $95 \%$ & 24.4 \\
\hline 6 & $\begin{array}{c}3 \text { feet @ Top of } \\
\text { Backslope } 2\end{array}$ & $\begin{array}{l}\text { Limestone (Hard } \\
\text { Bedrock), } 160 \mathrm{lb} / \mathrm{ft}^{3}\end{array}$ & 1.25 & $94 \%$ & 21.4 \\
\hline 4 & $\begin{array}{c}3 \text { feet @ Top of } \\
\text { Backslope } 3\end{array}$ & $\begin{array}{l}\text { Sandstone (Hard } \\
\text { Bedrock), } 150 \mathrm{lb} / \mathrm{ft}^{3}\end{array}$ & 1.0 & $98 \%$ & 19.8 \\
\hline 2 & $\begin{array}{c}3 \text { feet @ Middle of } \\
\text { Backslope } 2\end{array}$ & $\begin{array}{c}\text { Sandstone (Hard } \\
\text { Bedrock), } 150 \mathrm{lb} / \mathrm{ft}^{3}\end{array}$ & 1.0 & $100 \%$ & $\mathrm{n} / \mathrm{a}$ \\
\hline
\end{tabular}

\subsubsection{Bench Removal Feasibility Case Study Trial 2}

Since the redesigned slope section with only three benches was determined to be both structurally stable and safe to roadway users, the objective of the second bench reduction trial was to determine if the case study slope section can feasibly be reduced to only two geotechnical benches.

\subsection{SoilVision SVSlope ${ }^{\circledR}$ Results}

Since the failure plane with the lowest Factor of Safety was found in Bench 3, and only a small backslope was located above this bench, it was the bench that was removed. Additionally, the uppermost backslope's angle was increased from $61.2^{\circ}$ to $75.5^{\circ}$ to match the lower backslope angles. The remaining two benches were not moved, but the bench widths were increased to 35 feet. In the sensitivity analysis (Section 4.3), 35 foot benches consistently caught a safe amount of falling rocks, and with the large reduction in overall slope width it was feasible to increase bench widths without increasing excavation costs. Figure 6.10 shows the SVSlope ${ }^{\circledR}$ model for the second bench reduction. 


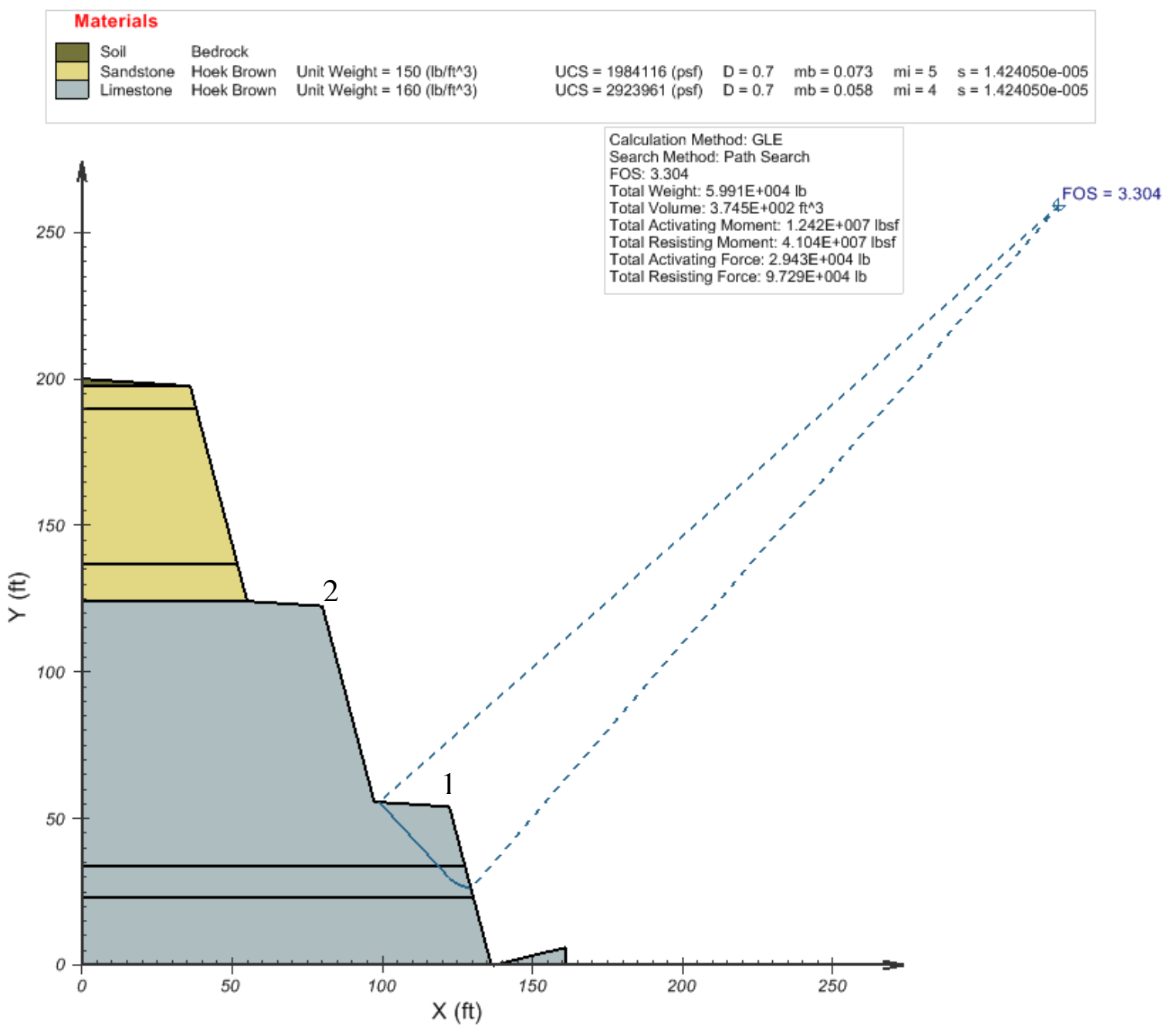

Figure 6.10 Two-Dimensional Slope Section Profile and Stability Analysis results for second bench removal case on US Route 48 slope section.

While it was expected for the slope section to remain structurally stable after the removal of the uppermost bench due to it being insignificant in the previous cases, Figure 6.10 shows that there was actually a significant increase in the overall Factor of Safety for the slope section. The new lowest Factor of Safety occurring on the slope section was equal to 3.30, and the slip surface was found starting on Bench 1 and exiting on Backslope 1. The exact reasoning for the significant increase in Factor of Safety is unknown, but it can be speculated that the increase in bench width created a longer potential slip surface, thus decreasing the potential of a failure to occur.

\subsection{CRSP-2D Simulation Results}

Figure 6.11 shows the slope model for the second bench removal case as it appears in CRSP-2D. Observing the minor differences in slope geometry between cases 1 and 2, it can be assumed that the rockfall simulation results will show a significant increase in on-slope rockfall retention due to the increase in bench width from 25 feet to 35 feet. Results from the simulation analysis can be found in Table 6.6. 


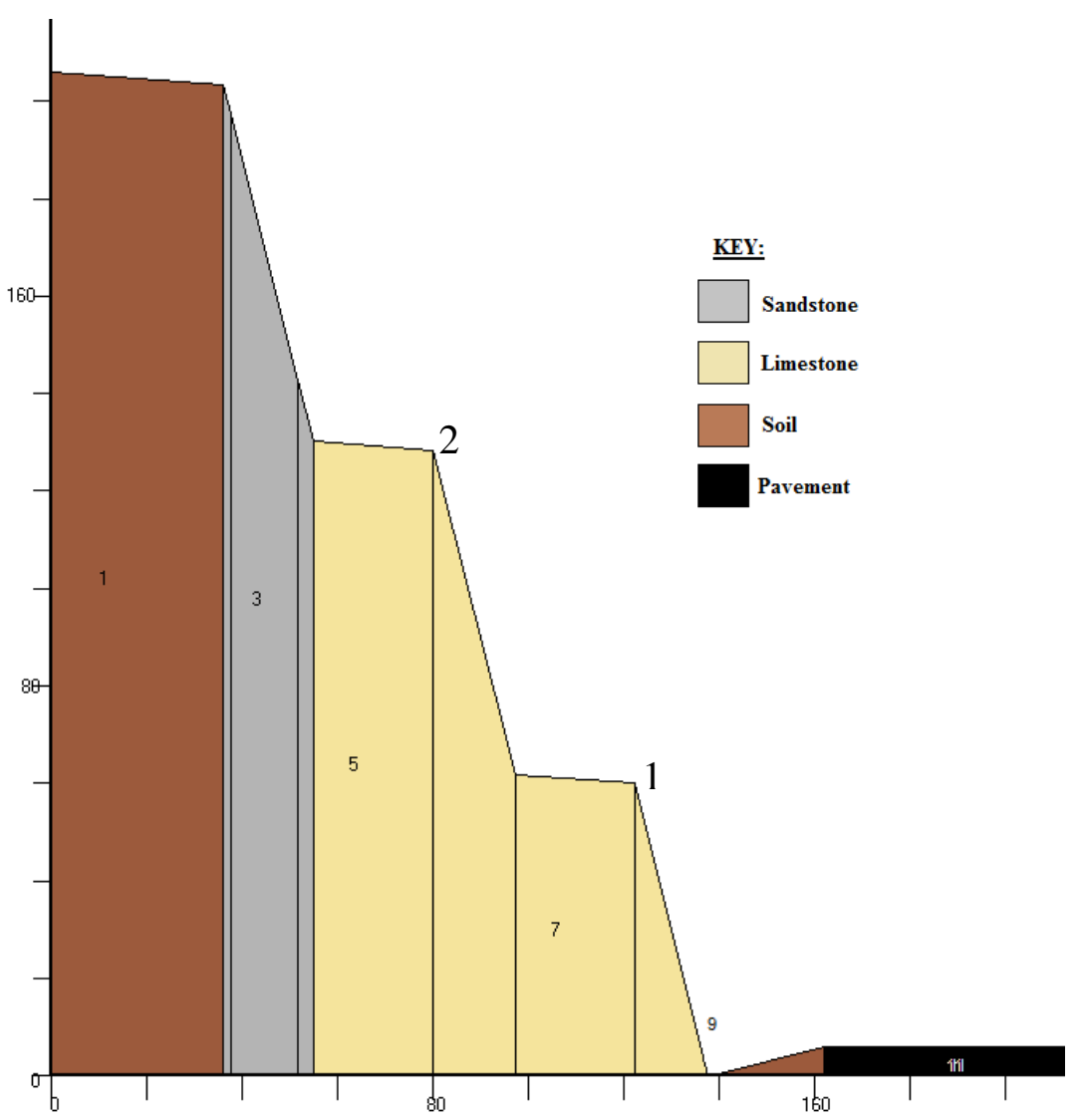

Figure 6.11 Two- Dimensional Slope Section Profile from second bench removal case of slope section of US Route 48 modeled in CRSP-2D

Table 6.6 CRSP-2D Simulation Runs with Various Rockfall Release Zones on Bench Reduction Trial 2 of US Route 48 Case Study Slope

\begin{tabular}{|c|c|c|c|c|c|}
\hline $\begin{array}{c}\text { Rockfall } \\
\text { Release } \\
\text { Zone } \\
\text { (Cell \#'s) }\end{array}$ & $\begin{array}{l}\text { Rockfall Release } \\
\text { Zone Description }\end{array}$ & $\begin{array}{l}\text { Rockfall Material } \\
\text { Type and Density }\end{array}$ & $\begin{array}{c}\text { Rockfall } \\
\text { Diameter } \\
\text { (ft.) }\end{array}$ & $\begin{array}{c}\text { Percentage } \\
\text { Retained } \\
\text { Before } \\
\text { Roadway }\end{array}$ & $\begin{array}{c}\text { Average } \\
\text { Runout Past } \\
\text { Ditch (ft.) }\end{array}$ \\
\hline 8 & $\begin{array}{c}3 \text { feet @ Top of } \\
\text { Backslope } 1\end{array}$ & $\begin{array}{c}\text { Limestone (Hard } \\
\text { Bedrock), } 160 \mathrm{lb} / \mathrm{ft}^{3}\end{array}$ & 1.0 & $100 \%$ & $\mathrm{n} / \mathrm{a}$ \\
\hline 6 & $\begin{array}{c}3 \text { feet @ Top of } \\
\text { Backslope } 2\end{array}$ & $\begin{array}{c}\text { Limestone (Hard } \\
\text { Bedrock), } 160 \mathrm{lb} / \mathrm{ft}^{3}\end{array}$ & 1.0 & $96 \%$ & 20.4 \\
\hline 6 & $\begin{array}{c}3 \text { feet @ Top of } \\
\text { Backslope } 2\end{array}$ & $\begin{array}{c}\text { Limestone (Hard } \\
\text { Bedrock), } 160 \mathrm{lb} / \mathrm{ft}^{3}\end{array}$ & 1.25 & $95 \%$ & 19.9 \\
\hline 2 & $\begin{array}{c}3 \text { feet @ Top of } \\
\text { Backslope } 3\end{array}$ & $\begin{array}{c}\text { Sandstone (Hard } \\
\text { Bedrock), } 150 \mathrm{lb} / \mathrm{ft}^{3}\end{array}$ & 1.0 & $98 \%$ & 19.5 \\
\hline
\end{tabular}

The CRSP-2D simulation results confirmed the previous assumptions, with an increase in percent of rockfall retained prior to roadway from all release zones. It was found that falling 
rocks slightly larger than 1 foot in diameter were more likely to reach the roadway when the rocks had a unit weight matching that of limestone, as the lowest percentage was observed when rocks were released from the top of Backslope 2. However, this percentage was still well above the minimum allowable value of $90 \%$ (ODOT, 2001). Thus, it can be assumed that this slope section of US Route 48 can be structurally stable and safe with only two geotechnical benches.

\subsubsection{Bench Removal Feasibility Case Study Trial 3}

Due to the competent rock strata composing the US Route 48 case study slope section, an additional bench reduction trial was run to determine if a rock cut slope composed of Type 1 Bedrock can be stable and safe with only one geotechnical bench. The maximum amount of vertical feet between benches for proper construction access and safe blasting is unknown. However, it is assumed that 200 feet, or the full case study slope section height, is over the maximum and thus a geotechnical bench was placed mid-slope. With one 35 foot bench, and a 25 foot RCAD ditch at the toe, the total width reduction from the original as-built slope to this trial 3 slope is 18 feet. Estimated excavation volume reductions can be found in Section 6.5.

\subsection{SoilVision SVSlope ${ }^{\circledR}$ Results}

All backslope angles were kept at $75.5^{\circ}$. A small soil overburden layer with a shallow angle was extended out in Figure 6.12, but was found to have no effect on the slope stability analysis.

Pentz (2014) confirmed that this slope section was capable of being constructed with only one geotechnical bench and thus an identical SVSlope ${ }^{\circledR}$ model was created for this portion for comparison of the 2-D and 3-D analysis (personal communication, July 17, 2014). 


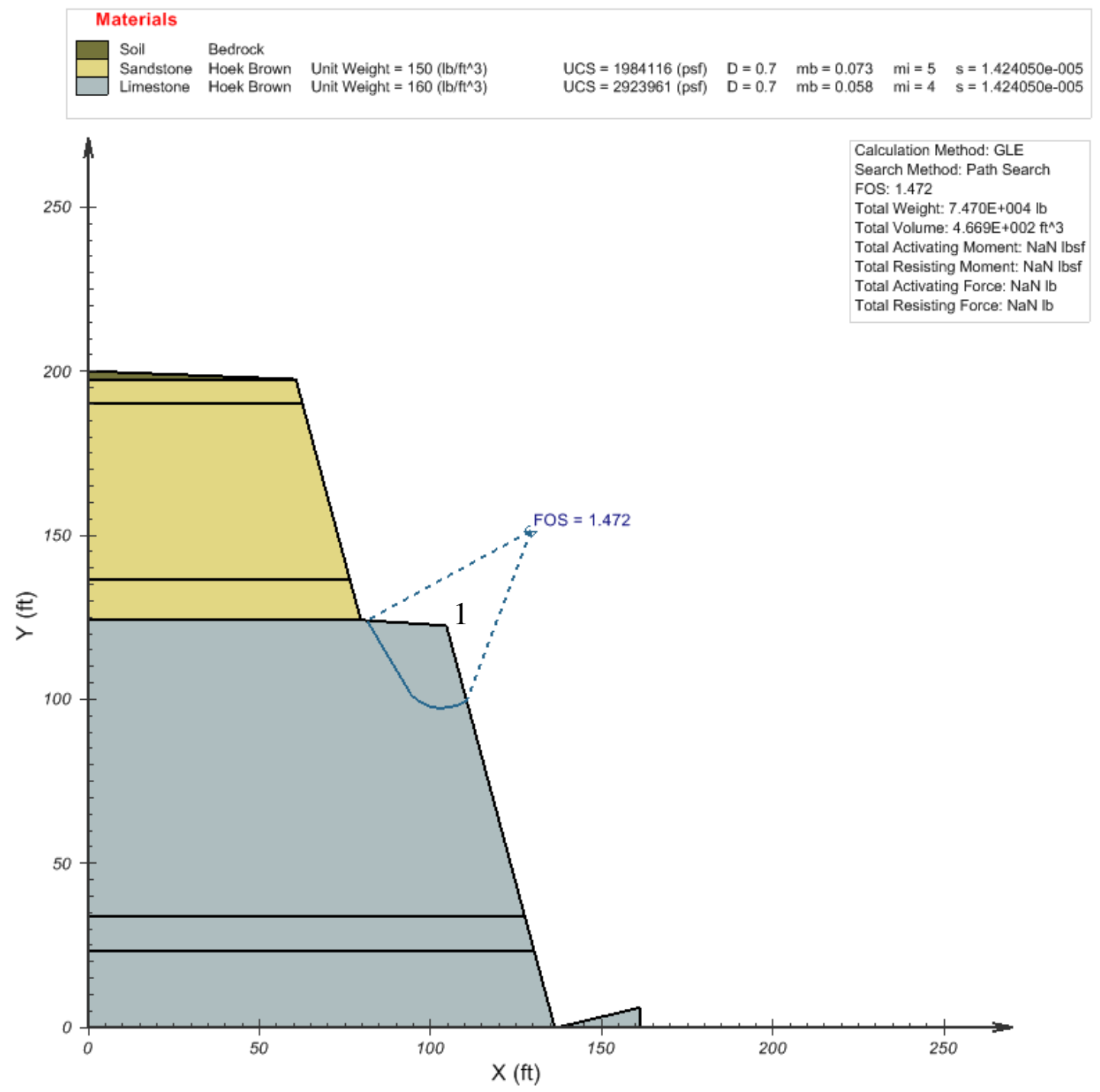

Figure 6.12 Two-Dimensional Slope Section Profile and Stability Analysis results for third bench removal case on US Route 48 slope section.

With only one geotechnical bench, Figure 6.11 shows that the overall Factor of Safety for the slope section remains above the minimum allowable value of 1.25. The weakest failure plane, found on the only remaining bench and extending into Backslope 1, has a Factor of Safety = 1.47. This value is very similar to the minimum Factor of Safety value from Case 2 (see Figure 6.8), in which the failure also occurred on the bench separating the sandstone and limestone layers. Overall, the US Route 48 case study slope section with only one geotechnical bench is found to be structurally stable.

\subsection{CRSP-2D Results}

Figure 6.13 displays the model developed in CRSP-2D for rockfall simulations. Table 6.7 shows the simulation results. There were only two possible sections of the slope for consideration as the worst case release zones when running rockfall simulations. As in the previous case, it was found that falling rocks slightly larger than 1 foot in diameter were more likely to reach the roadway when the rocks had a unit weight matching that of limestone. With a unit weight matching sandstone, rocks with a diameter of 1.0 feet travelled the farthest on average. Rock diameters from 0.80 to 4.0 feet were simulated. 


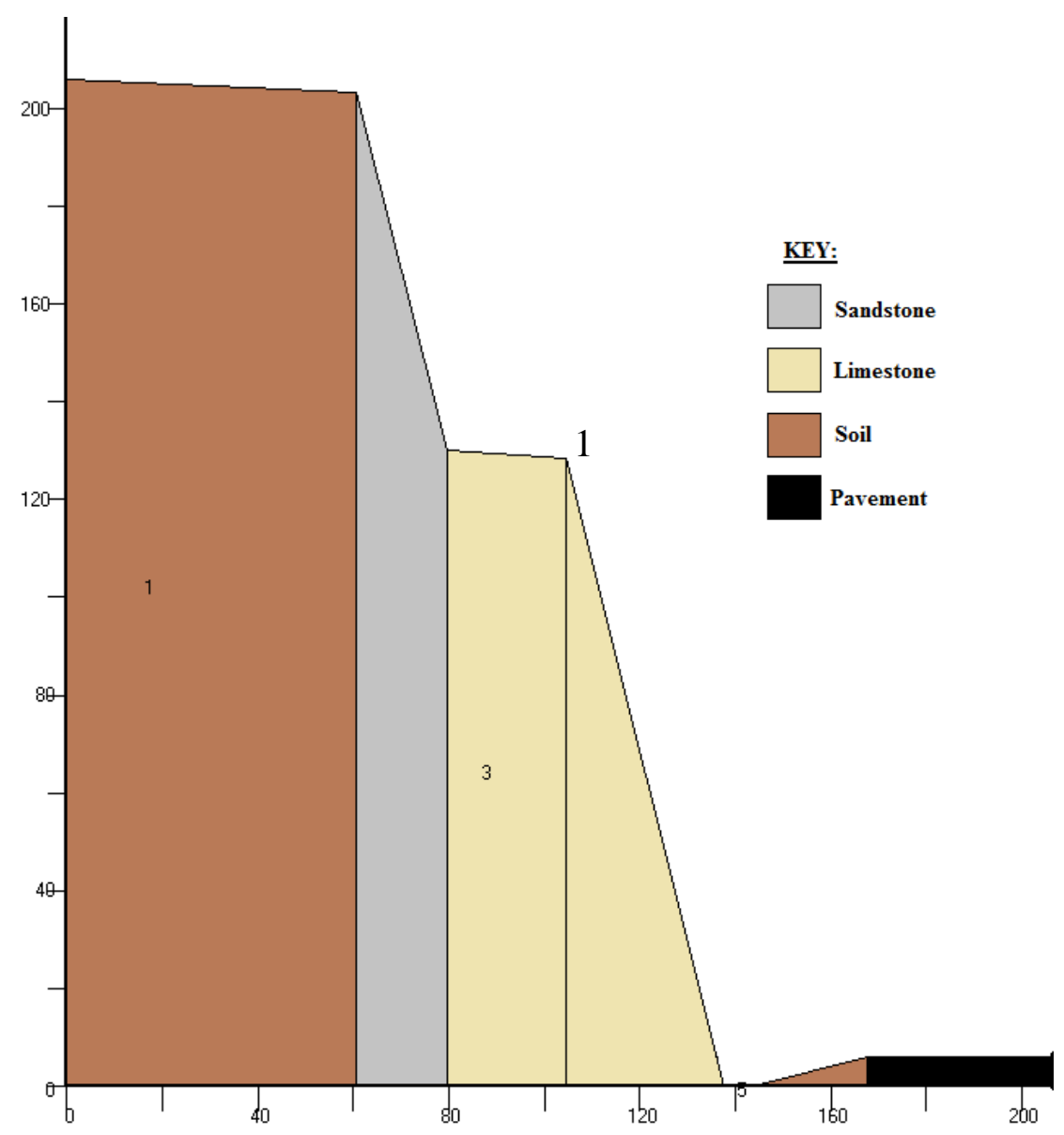

Figure 6.13 Two- Dimensional Slope Section Profile from third bench removal case of slope section of US Route 48 modeled in CRSP-2D

Table 6.7 CRSP-2D Simulation Runs with Various Rockfall Release Zones on Bench Reduction Trial 4 of US Route 48Case Study Slope

\begin{tabular}{|c|c|c|c|c|c|}
\hline $\begin{array}{c}\text { Rockfall } \\
\text { Release } \\
\text { Zone } \\
\text { (Cell \#'s) }\end{array}$ & $\begin{array}{l}\text { Rockfall Release } \\
\text { Zone Description }\end{array}$ & $\begin{array}{l}\text { Rockfall Material } \\
\text { Type and Density }\end{array}$ & $\begin{array}{l}\text { Rockfall } \\
\text { Diameter } \\
\text { (ft.) }\end{array}$ & $\begin{array}{l}\text { Percentage } \\
\text { Retained } \\
\text { Before } \\
\text { Roadway }\end{array}$ & $\begin{array}{c}\text { Average } \\
\text { Runout Past } \\
\text { Ditch (ft.) }\end{array}$ \\
\hline 4 & $\begin{array}{c}3 \text { feet @ Top of } \\
\text { Backslope } 1\end{array}$ & $\begin{array}{c}\text { Limestone (Hard } \\
\text { Bedrock), } 160 \mathrm{lb} / \mathrm{ft}^{3}\end{array}$ & 1.0 & $91 \%$ & 21.5 \\
\hline 4 & $\begin{array}{c}3 \text { feet @ Top of } \\
\text { Backslope } 1\end{array}$ & $\begin{array}{l}\text { Limestone (Hard } \\
\text { Bedrock), } 160 \mathrm{lb} / \mathrm{ft}^{3}\end{array}$ & 1.25 & $88 \%$ & 19.4 \\
\hline 6 & $\begin{array}{c}3 \text { feet @ Top of } \\
\text { Backslope } 2\end{array}$ & $\begin{array}{c}\text { Sandstone (Hard } \\
\text { Bedrock), } 150 \mathrm{lb} / \mathrm{ft}^{3}\end{array}$ & 1.0 & $91 \%$ & 25.7 \\
\hline
\end{tabular}

Table 6.7 shows that 1.25 diameter rocks falling from the top of Backslope 1 do not meet the minimum recommended percent rockfall retention of $90 \%$ (ODOT, 2001). See Appendix V for a visual representation of this rockfall trajectory. The remainder of the results does meet minimum 
requirements. With the overall reduction in slope width, there is room to increase the RCAD ditch width, which would presumably increase rockfall retention to acceptable percentages for all tested release zones. Thus, if blasting and construction is manageable with only one geotechnical bench on the case study slope section of Route 48, then it can stably and safely be designed and constructed.

\subsubsection{US Route 48 Case Study Overall Results}

Table 6.8 US Route 48 Bench Removal Feasibility Case Study Overall Results

\begin{tabular}{|c|c|c|c|c|}
\hline $\begin{array}{c}\text { Bench Removal } \\
\text { Case }\end{array}$ & $\begin{array}{c}\text { Number of } \\
\text { Geotechnical } \\
\text { Benches on Slope }\end{array}$ & $\begin{array}{c}\text { Rockfall Release } \\
\text { Zone producing } \\
\text { Lowest Retention } \\
\text { Percentage }\end{array}$ & $\begin{array}{c}\text { Lowest On- } \\
\text { Slope } \\
\text { Retention } \\
\text { Percentage }\end{array}$ & $\begin{array}{c}\text { Stability Factor of } \\
\text { Safety }\end{array}$ \\
\hline As-Built & 5 & Backslope 2 & $75 \%$ & 3.63 \\
\hline $\mathbf{1}$ & 3 & Backslope 2 & $94 \%$ & 1.49 \\
\hline $\mathbf{2}$ & 2 & Backslope 2 & $95 \%$ & 3.30 \\
\hline $\mathbf{3}$ & 1 & Backslope 1 & $88 \%$ & 1.47 \\
\hline
\end{tabular}

\subsubsection{US Route 121 Case Study}

Table 6.9 displays the borehole log information of the slope section on US Route 121, along with the CRSP-2D coefficient designation for each material type. 
Table 6.9 Geometric Information for US Route 121 Case Study Slope Section

\begin{tabular}{|c|c|c|c|}
\hline $\begin{array}{l}\text { Vertical Depth from } \\
\text { Initial Grade (ft.) }\end{array}$ & $\begin{array}{l}\text { Initial Vertical Height } \\
\text { from Toe Grade (ft.) }\end{array}$ & Material Type & CRSP Designation \\
\hline 0 - 5 & 337.16 & Soil - Silty Sand with Gravel & Loose Soil \\
\hline $5-15$ & 332.16 & Soil - Silty Sand & Loose Soil \\
\hline $15-22.8$ & 322.16 & Sandstone & Hard Bedrock \\
\hline $22.8-49.0$ & 314.36 & Siltstone & Soft Bedrock \\
\hline $49.0-64.2$ & 288.16 & Sandstone & Hard Bedrock \\
\hline $64.2-91.0$ & 272.96 & Sandstone & Hard Bedrock \\
\hline 91.0 - 96.0 & 246.16 & Siltstone & Soft Bedrock \\
\hline $96.0-103.3$ & 241.16 & Sandstone & Hard Bedrock \\
\hline $103.3-104.5$ & 233.86 & Siltstone & Soft Bedrock \\
\hline $104.5-118.0$ & 232.66 & Sandstone & Hard Bedrock \\
\hline $118.0-120.1$ & 219.16 & Sandstone & Hard Bedrock \\
\hline $120.1-121.2$ & 217.06 & Coal & Soft Bedrock \\
\hline $121.2-124.0$ & 215.96 & Siltstone & Soft Bedrock \\
\hline $124.0-137.5$ & 213.16 & Sandstone & Hard Bedrock \\
\hline $137.5-192.7$ & 199.96 & Siltstone & Soft Bedrock \\
\hline $192.7-236.2$ & 144.46 & ${ }^{*}$ Gap between borehole logs & N/A \\
\hline $236.2-264.9$ & 100.96 & Siltstone & Soft Bedrock \\
\hline $264.9-271.2$ & 72.26 & Sandstone & Hard Bedrock \\
\hline $271.2-274.1$ & 65.96 & Sandstone & Hard Bedrock \\
\hline $274.1-301.2$ & 63.06 & Siltstone & Soft Bedrock \\
\hline $301.2-329.7$ & 35.96 & Sandstone & Hard Bedrock \\
\hline $329.7-337.16$ & 7.46 & Siltstone & Soft Bedrock \\
\hline $337.16-351.2$ & - & Coal & Soft Bedrock \\
\hline $351.2-371.0$ & - & Siltstone & Soft Bedrock \\
\hline
\end{tabular}

Note that there was a $43.5 \mathrm{ft}$. gap between the two borehole logs used for this slope section approximately 145 feet above toe grade. From visual observations, this missing section was 
assumed to be comprised completely of siltstone, as the layers directly above and below were siltstone. To avoid the need for assumptions like this, boreholes should be drilled to obtain material information for the complete depth of all large cuts. Due to the varying stratigraphy of the Appalachian Mountains, borehole logs just 100 feet apart may be drastically different, and assumptions from neighboring boreholes may lead to failing cut slopes after excavation.

\subsubsection{As-built Slope: Feasibility Case Study}

Table 6.1 (in Section 6.3), along with Figure 6.14, displays the backslope heights and bench widths of the as-built slope section on US Route 121. This geometric data was used in both of the computer modeling programs to create the slope profile for the initial feasibility study of the as-built slope.

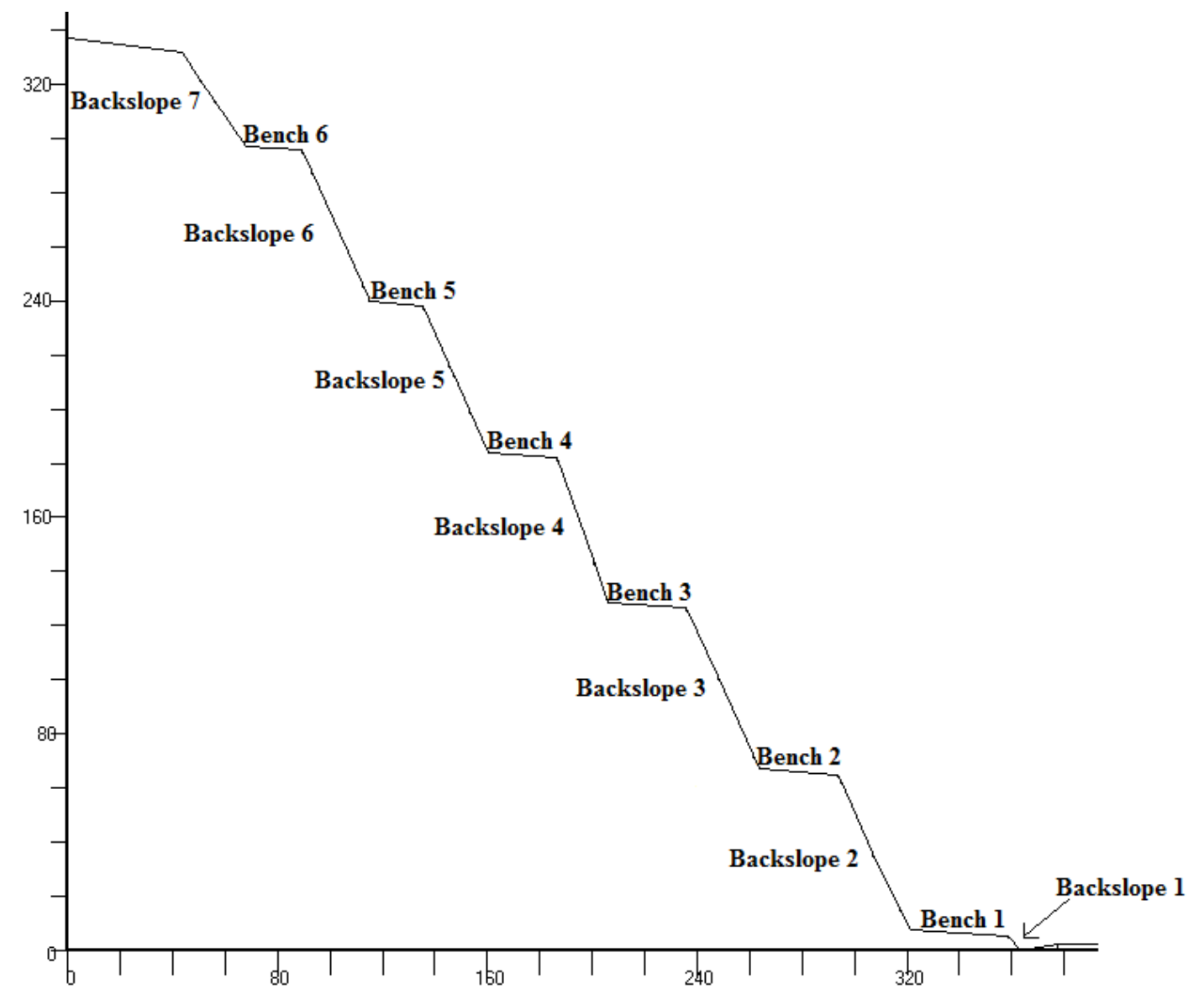

Figure 6.14 Two-Dimensional Profile of As-built Slope Section of US Route 121

\subsection{SoilVision SVSlope ${ }^{\circledR}$ Results}

Figure 6.15 displays the finished model in SVSlope ${ }^{\circledR}$. The material inputs for the slope section can be seen in the "Materials" key at the top of the figure. The overburden layer at the top of the slope was input as Bedrock (instead of soil) so failure planes would not occur in this layer. This was done so only rock material layers would be analyzed. The inputs for the Sandstone and Siltstone layers, including unit weight, Unified Compressive Strength, Disturbance Factor (D), and Hoek Brown constants $m b, m i$, and $s$ (See Section 5.1). Table 6.3 in Section 6.4.1.1.1 displays the average values for Unified Compressive Strength (UCS), the Hoek Brown constants, and unit weights for each rock type used in the case studies. These values, except for the unit weights, were originally selected by Kulbacki (2014), whom referenced the values from Zhao (2010) and Sjöberg (1997). The unit weights for each material type can also be found in 
published literature (Zhao, 2010), but differ from the values used by Kulbacki (2014). The Disturbance Factor, which has a potential range of 0.6 for good blasting to 1.0 for poor blasting, was given the maximum value of 1.0 (Hoek, 2007). This was the condition observed in the field, which had been visually over-blasted in many areas. Additionally, it can be considered that if the slope is designed to be stable even with poor blasting, then it will be stable in all conditions.

Kulbacki (2014) constructed a similar model to the one shown in Figure 6.15, due to the combining field observations and measurements of the Coalfields Expressway site, however different unit weights were selected for the slope materials in this analysis.

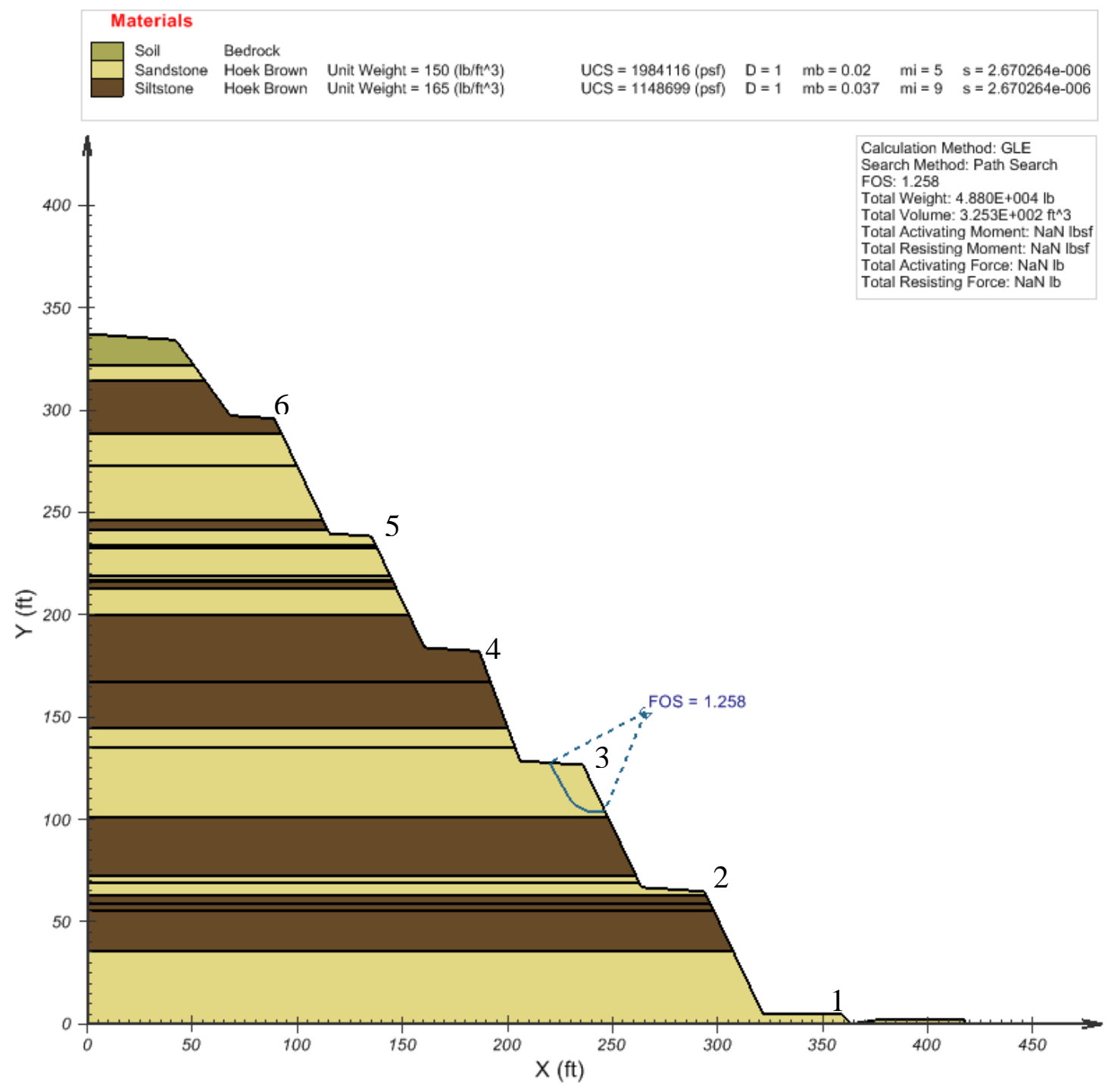

Figure 6.15 Two-Dimensional Slope Section Profile and Stability Analysis results for Asbuilt slope section on US Route 121.

The results in Figure 6.15 show that the slope is stable with a Factor of Safety of 1.26, and also barely exceeds the minimum required Factor of Safety by WVDOT of 1.25. The weakest failure plane is located on Bench 3 and extends into Backslope 3. Additional testing showed three other potential failure planes below a Factor of Safety of 1.75, all located in Bench 4. 
As previously mentioned in Section 5.2, small changes to slope properties may create noticeable changes to the overall Factor of Safety when modeled and analyzed with SoilVision SVSlope ${ }^{\circledR}$. Since these case studies are only being used as examples of how the analysis process works, it is assumed that the Factor of Safety $=1.25$ is accurate and the slope is stable. However, this may not accurately resemble actual field conditions. With a modeled Factor of Safety so low, additional material testing should be conducted to reduce the amount of assumptions and ensure that the slope section is indeed structurally stable.

\subsection{CRSP-2D Simulation Results}

After inputting the geometry for the slope section, the surface roughnesses, $R_{t}$, and $R_{n}$ values for each cell needed to be determined. Using the borehole logs and field observations, the following was determined:

- For the materials described as Siltstone or Coal, the calibrated CRSP normal coefficient values for Soft Bedrock were used. For consistency with the sensitivity analysis in Section 4.3.4, $\mathrm{R}_{\mathrm{n}}=0.25$ was selected for all soft bedrock strata layers.

- For the material described as Sandstone, the calibrated CRSP normal coefficient values for Hard Bedrock were used. For consistency with the sensitivity analysis in Section 4.3.4, $R_{n}=0.30$ was selected for all hard bedrock strata layers.

- The catchment area between the toe of the slope section and the roadway was estimated to be a compacted clay with $R_{n}=0.20$.

- The roadway was a hard concrete asphalt surface, and was given an $R_{n}=0.80$.

- All surfaces were given a tangential coefficient value of $R_{t}=0.92$. This value was selected because it was within the range of every material type within the slope, and allowed for consistency.

- For Cell \#36 (the first backslope), $\mathrm{R}_{\mathrm{t}}$ was decreased by 0.01 to $\mathrm{R}_{\mathrm{t}}=0.91$ due to high vegetation.

- Surface roughness $(S)$ values were selected as $S=0.5$ for competent rock backslopes, $S=$ 0.01 for all benches and roadway, and $S=0.2$ for compacted soil backslopes. These are assumed values, and were selected based on averaging field observations since actual field measurements for surface roughness were not taken.

Rockfall release zones were varied between simulation runs. While the SVSlope ${ }^{\circledR}$ results found that the most potential failure zones were in the top of Backslopes 2 and 3, but all backslopes were tested as potential release zones. The goal was to find the worst feasible case for rockfall runout to ensure that the entire slope is safe. A retention of $90 \%$ on-slope was set as the desired outcome, as recommended by Oregon DOT (ODOT, 2012). Figure 6.16 shows the as-built slope model in CRSP-2D. Table 6.10 displays the results of each simulation run using CRSP-2D on the slope section. 


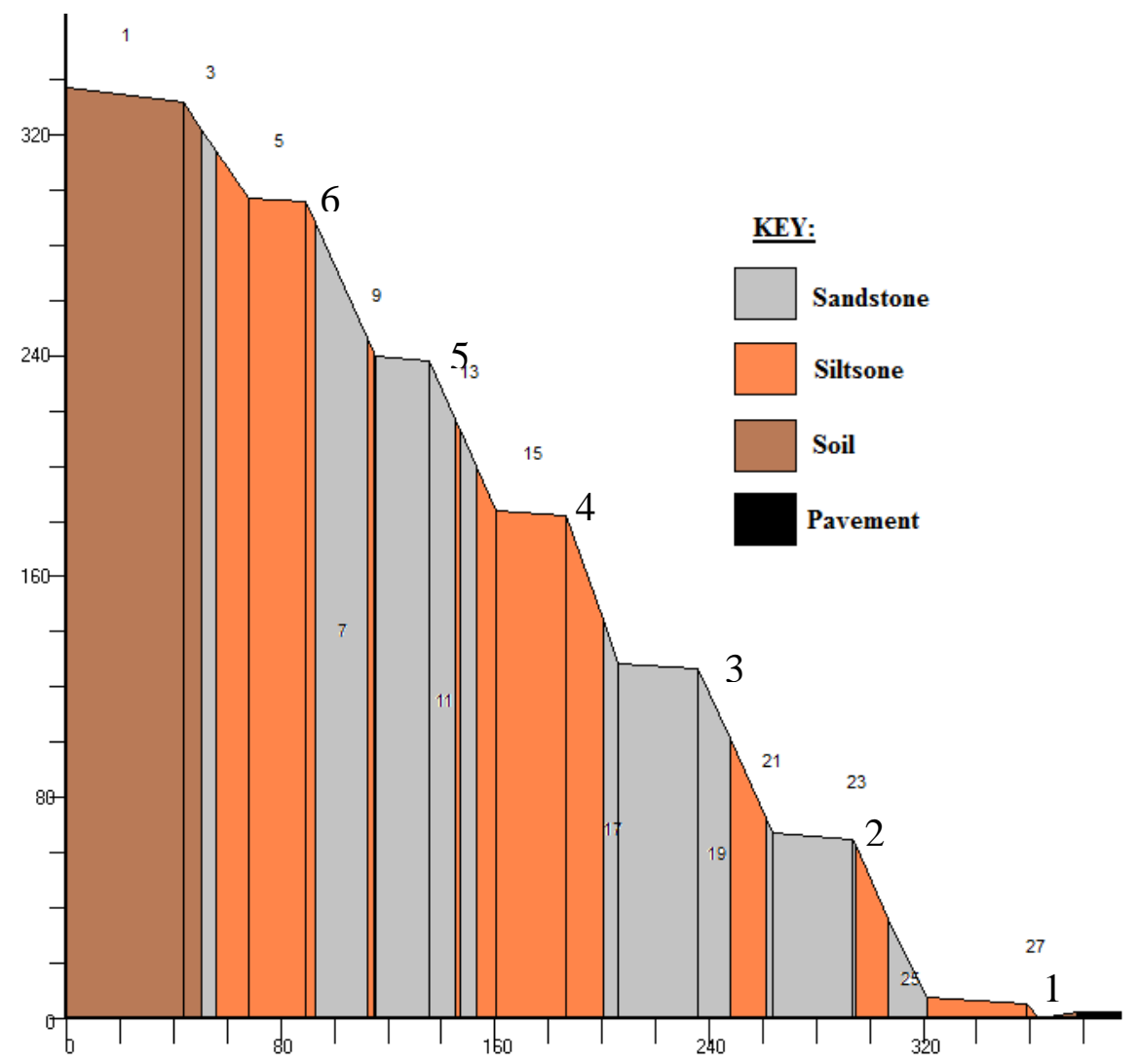

Figure 6.16 Two-Dimensional Slope Section Profile from As-built slope section of US Route 121 modeled in CRSP-2D 
Table 6.10 CRSP-2D Simulation Runs with Various Rockfall Release Zones on Case Study Slope on US Route 121

\begin{tabular}{|c|c|c|c|c|c|}
\hline $\begin{array}{c}\text { Rockfall } \\
\text { Release Zone } \\
\text { (Cell \#'s) }\end{array}$ & $\begin{array}{l}\text { Rockfall Release } \\
\text { Zone Description }\end{array}$ & $\begin{array}{c}\text { Rockfall } \\
\text { Material Type } \\
\text { and Density }\end{array}$ & $\begin{array}{l}\text { Rockfall } \\
\text { Diameter } \\
\text { (ft.) }\end{array}$ & $\begin{array}{c}\text { Percentage } \\
\text { Retained on } \\
\text { Slope }\end{array}$ & $\begin{array}{c}\text { Average } \\
\text { Runout Past } \\
\text { Slope (ft.) }\end{array}$ \\
\hline 23 & $\begin{array}{c}1.75 \text { feet @ top of } \\
\text { Backslope } 2\end{array}$ & $\begin{array}{l}\text { Hard bedrock, } \\
150 \mathrm{lb} / \mathrm{ft}^{3}\end{array}$ & 1.0 & $92 \%$ & 4.0 \\
\hline 23 & $\begin{array}{c}1.75 \text { feet @ top of } \\
\text { Backslope } 2\end{array}$ & $\begin{array}{l}\text { Hard bedrock, } \\
150 \mathrm{lb} / \mathrm{ft}^{3}\end{array}$ & 1.5 & $99 \%$ & 2.9 \\
\hline 24 & $\begin{array}{l}3 \text { feet @ mid- } \\
\text { Backslope } 2\end{array}$ & $\begin{array}{l}\text { Soft Bedrock, } \\
165 \mathrm{lb} / \mathrm{ft}^{3}\end{array}$ & 1.0 & $97 \%$ & 2.75 \\
\hline 19 & $\begin{array}{c}3 \text { feet @ top of } \\
\text { Backslope } 3\end{array}$ & $\begin{array}{l}\text { Hard Bedrock, } \\
150 \mathrm{lb} / \mathrm{ft}^{3}\end{array}$ & 1.0 & $99 \%$ & 2.5 \\
\hline 16 & $\begin{array}{c}3 \text { feet @ top of } \\
\text { Backslope } 4\end{array}$ & $\begin{array}{l}\text { Soft Bedrock, } \\
165 \mathrm{lb} / \mathrm{ft}^{3}\end{array}$ & 1.0 & $99.5 \%$ & 4.8 \\
\hline 13 & $\begin{array}{c}3 \text { feet @ top of } \\
\text { Backslope } 5\end{array}$ & $\begin{array}{l}\text { Hard Bedrock, } \\
150 \mathrm{lb} / \mathrm{ft}^{3}\end{array}$ & 1.0 & $100 \%$ & $\mathrm{n} / \mathrm{a}$ \\
\hline 6 & $\begin{array}{l}7.5 \text { feet @ top of } \\
\text { Backslope } 6\end{array}$ & $\begin{array}{l}\text { Soft Bedrock, } \\
165 \mathrm{lb} / \mathrm{ft}^{3}\end{array}$ & 1.0 & $100 \%$ & $\mathrm{n} / \mathrm{a}$ \\
\hline 7 & $\begin{array}{l}50 \text { feet @ mid- } \\
\text { Backslope } 6\end{array}$ & $\begin{array}{l}\text { Hard Bedrock, } \\
150 \mathrm{lb} / \mathrm{ft}^{3}\end{array}$ & 1.0 & $100 \%$ & $\mathrm{n} / \mathrm{a}$ \\
\hline 3 & $\begin{array}{c}8 \text { feet @ top of } \\
\text { Backslope } 7\end{array}$ & $\begin{array}{l}\text { Hard Bedrock, } \\
150 \mathrm{lb} / \mathrm{ft}^{3}\end{array}$ & 1.0 & $100 \%$ & $\mathrm{n} / \mathrm{a}$ \\
\hline
\end{tabular}

In the preliminary simulation runs, it was found that falling rocks with a diameter larger than 1.5 feet were less likely to leave the first bench they encountered compared to smaller rocks. Thus, larger rocks were not considered in Table 6.10. The results show that regardless of where rockfall was released on the slope, the wide benches easily collected over $90 \%$ of rockfall before reaching the toe of slope. Thus, this section of rock cut slope on US Route 121, in its in situ field-measured state, is safe for roadway users without the need of additional rockfall catchment.

\subsubsection{Bench Removal Feasibility Case Study Trial 1}

Since both Factor of Safety and on-slope rockfall retention met the required criteria for the fieldmeasured slope section, alterations to the slope geometry were made with the objective of reduction in excavation costs without reducing roadway user safety or slope stability.

\subsection{SoilVision SVSlope ${ }^{\circledR}$ Results}

It was assumed that the most feasible bench to initially remove was Bench 4, while moving Bench 3 down the slope to cut into the top of a weaker Soft Bedrock layer. This aids in the 
prevention of undercutting. Figure 6.17 shows the new geometry of the slope section after the initial bench removal.

It was observed that Kulbacki (2014) created a similar model to that shown in Figure 6.17. This analysis uses a different unit weight values for the slope materials thus computing different factor of safety outcomes.

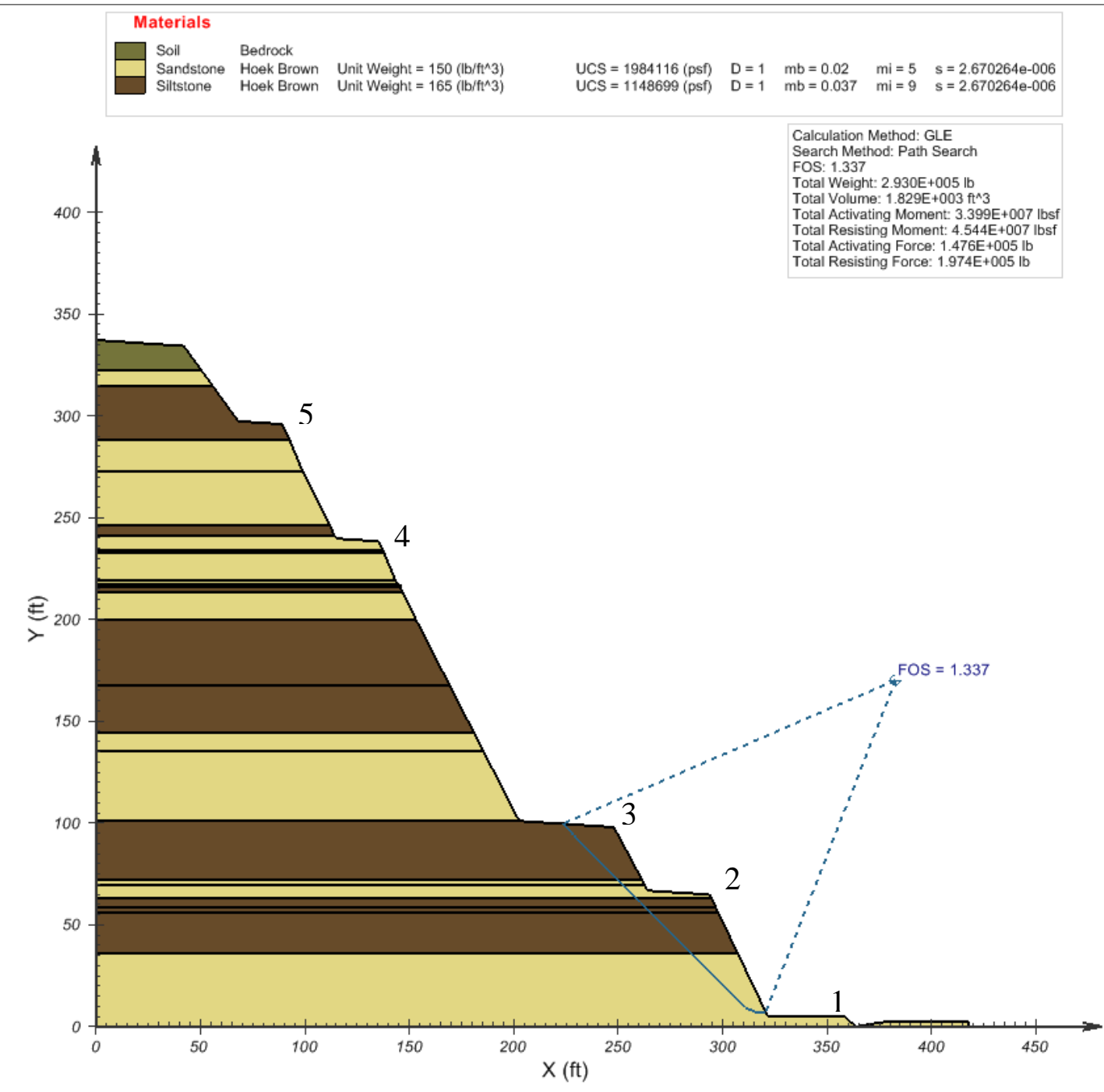

Figure 6.17 Two-Dimensional Slope Section Profile and Stability Analysis results for Bench Reduction Trial 1 slope section on US Route 121.

While the overall bench layout of Trial 1 appears unorthodox, the removal of the fourth bench produced an acceptable stability Factor of Safety of 1.34. The weakest failure plane in the first bench reduction trial slope started on Bench 3 and ran all the way down to the top of Bench 1 . No additional failure planes produced Factors of Safety less than 1.75. Overall, this first bench reduction trial is considered structurally stable.

\subsection{CRSP-2D Simulation Results}

Figure 6.18 shows the change in slope profile after the removal of Bench 4 and adjustment of Bench 3. The same assumptions for CRSP-2D coefficient values and rockfall sizes are used from Section 6.4.2.1.2. 


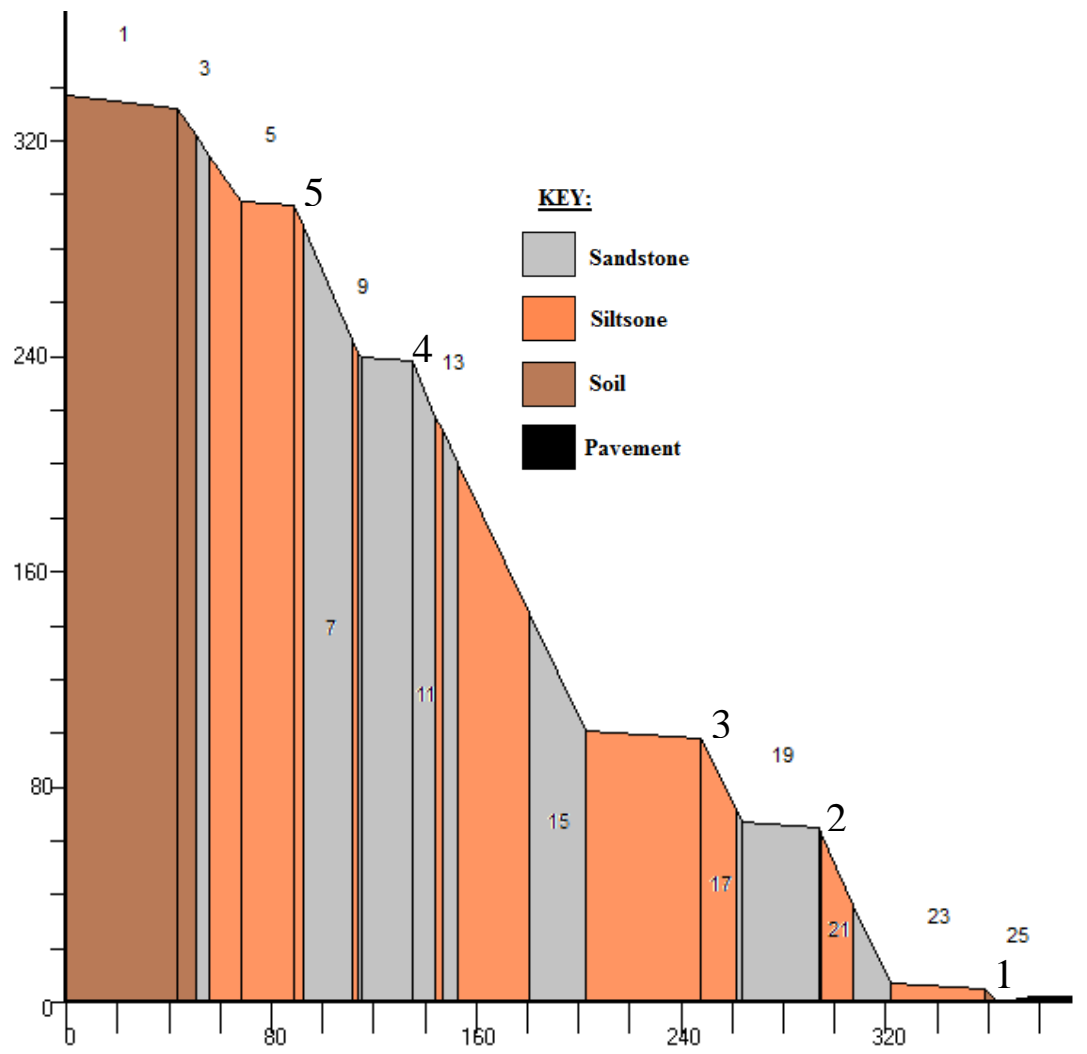

Figure 6.18 Two- Dimensional Slope Section Profile from first bench removal case of slope section of US Route 121 modeled in CRSP-2D

Observing Figure 6.17, it can be predicted that the release zone on the slope that will create the largest runout is the top of Backslope 4 (Cell 11). Additionally, observing the SVSlope ${ }^{\circledR}$ results, the weakest portion of the slope were Backslopes 2 and 3. These two areas were the focus of the simulation trials run in CRSP-2D for the first bench removal condition. However, all areas of the slope face were tested to ensure that the worst case release zone still provides safe results for roadway users. Table 6.11 displays the results for each simulation trial. 
Table 6.11 CRSP-2D Simulation Runs on US Route 121 Slope Case Study: Bench Reduction Case 1

\begin{tabular}{|c|c|c|c|c|c|}
\hline $\begin{array}{c}\text { Rockfall } \\
\text { Release Zone } \\
\text { (Cell \#'s) }\end{array}$ & $\begin{array}{c}\text { Rockfall Release } \\
\text { Zone Description }\end{array}$ & $\begin{array}{c}\text { Rockfall } \\
\text { Material Type } \\
\text { and Density }\end{array}$ & $\begin{array}{c}\text { Rockfall } \\
\text { Diameter } \\
(\mathbf{f t} \text {.) }\end{array}$ & $\begin{array}{c}\text { Percentage } \\
\text { Retained on } \\
\text { Slope }\end{array}$ & $\begin{array}{c}\text { Average } \\
\text { Runout Past } \\
\text { Slope (ft.) }\end{array}$ \\
\hline 20 & $\begin{array}{c}1.75 \text { feet @ top of } \\
\text { Backslope 2 }\end{array}$ & $\begin{array}{c}\text { Hard bedrock, } \\
150 \mathrm{lb} / \mathrm{ft}^{3}\end{array}$ & 1.0 & $93 \%$ & 3.8 \\
\hline 20 & $\begin{array}{c}1.75 \text { feet @ top of } \\
\text { Backslope 2 }\end{array}$ & $\begin{array}{c}\text { Hard bedrock, } \\
150 \mathrm{lb} / \mathrm{ft}^{3}\end{array}$ & 1.5 & $99 \%$ & 2.8 \\
\hline 21 & $\begin{array}{c}3 \text { feet @ mid- } \\
\text { Backslope 2 }\end{array}$ & $\begin{array}{c}\text { Soft Bedrock, } \\
165 \mathrm{lb} / \mathrm{ft}^{3}\end{array}$ & 1.0 & $97 \%$ & $\mathrm{n} / \mathrm{a}$ \\
\hline 17 & $\begin{array}{c}3 \text { feet @ top of } \\
\text { Backslope 3 }\end{array}$ & $\begin{array}{c}\text { Soft Bedrock, } \\
165 \mathrm{lb} / \mathrm{ft}^{3}\end{array}$ & 1.0 & $100 \%$ & $\mathrm{n} / \mathrm{a}$ \\
\hline 11 & $\begin{array}{c}3 \text { feet @ top of } \\
\text { Backslope 4 }\end{array}$ & $\begin{array}{c}\text { Hard bedrock, } \\
150 \mathrm{lb} / \mathrm{ft}^{3}\end{array}$ & 1.0 & $100 \%$ & $\mathrm{n} / \mathrm{a}$ \\
\hline 6 & $\begin{array}{c}7.5 \text { feet @ top of } \\
\text { Backslope 5 }\end{array}$ & $\begin{array}{c}\text { Soft Bedrock, } \\
165 \mathrm{lb} / \mathrm{ft}^{3}\end{array}$ & 1.0 & $100 \%$ & $\mathrm{n} / \mathrm{a}$ \\
\hline 3 & $\begin{array}{c}\text { 8feet @ top of } \\
\text { Backslope 6 }\end{array}$ & $\begin{array}{c}\text { Hard Bedrock, } \\
150 \mathrm{lb} / \mathrm{ft}^{3}\end{array}$ & 1.0 & $100 \%$ & \\
\hline
\end{tabular}

Results from the first bench removal were nearly identical to those from the original slope profile. All tested rockfall release zones provided greater than $90 \%$ on-slope rockfall retention. This was due in large part to the $45 \mathrm{ft}$. wide Bench 3, which was created due to the removal of the previous Bench 4 and the desire to keep backslope angles and overall slope width the same. Benches this large may not be common design practice, and thus additional testing should be done with this slope if Bench 3 is designed with a smaller width. As designed in this case study, both Factor of Safety and rockfall retention met the required criteria for implementation.

\subsubsection{Bench Removal Feasibility Case Study Trial 2}

Since the removal of one bench increased Factor of Safety in the slope, while continuing to retain nearly all rockfall on-slope, the next step was to redesign the slope with only 3 geotechnical benches. While Trial 1 only involved the removal of a bench without further alterations to the initially constructed slope, this trial required a complete redesign.

\subsection{SoilVision SVSlope ${ }^{\circledR}$ Results}

The first two benches in the redesigned slope section were placed at the top of the two largest siltstone layers. These locations were selected to aid in the reduction of undercutting. The siltstone layers are more likely to have a higher erosion rate, so benching at the top of these layers places additional material below the slower-eroding sandstone layers to reduce the rate of undercutting. The benches were given widths of 25 feet to aid in proper on-slope rockfall catchment. The uppermost bench in the redesign was kept at the same height as the previous trials, but was also increased to 25 feet in width. Additionally, the lowest bench (Bench 1) was 
removed, and Backslope 1 was extended to the toe of slope. At this point, an RCAD-style ditch was implemented. The sensitivity analysis in Section 4.3 determined a ditch was significantly more effective in retaining rockfall compared to a lower bench. The final redesign is shown in Figure 6.19.

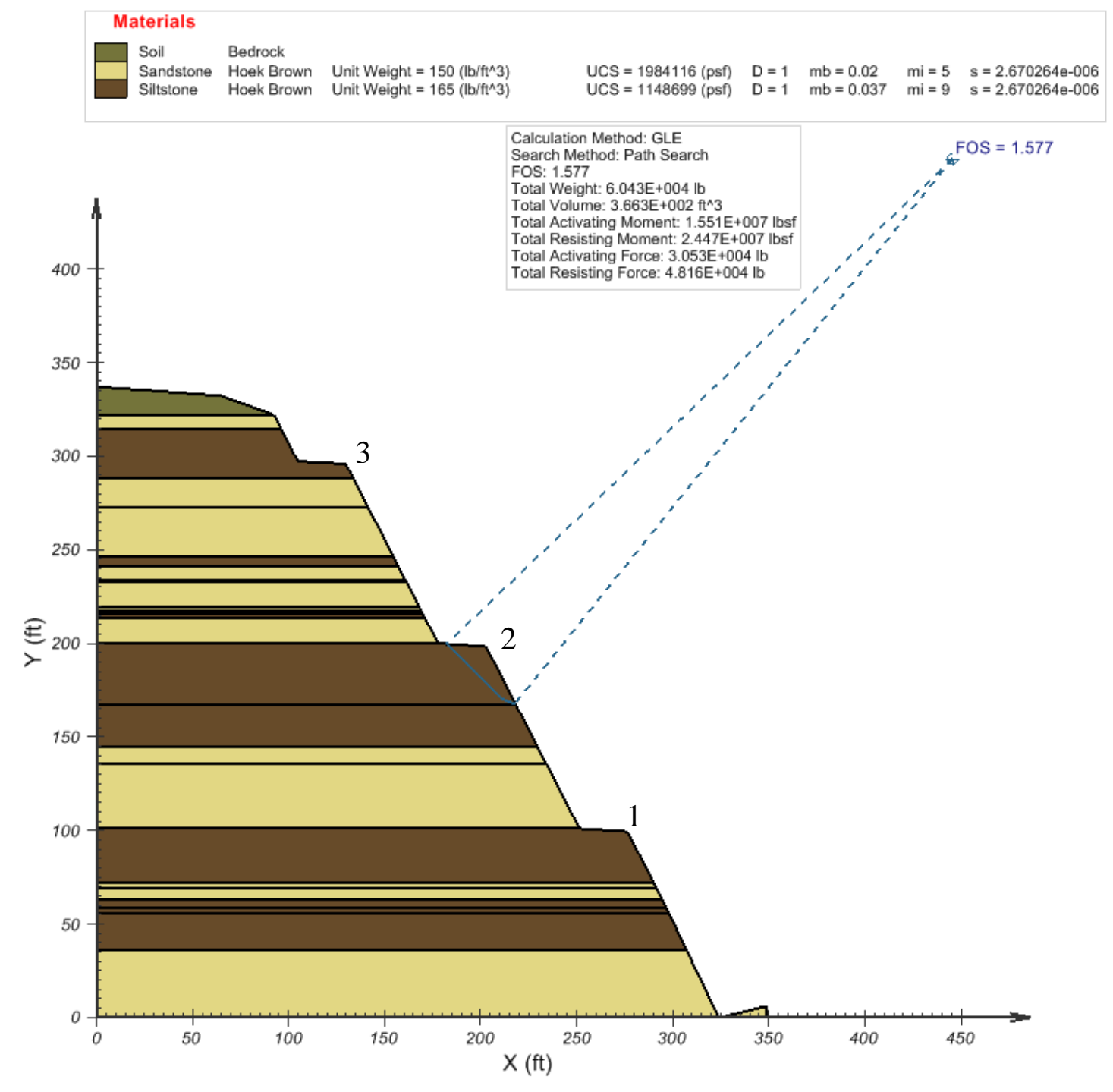

Figure 6.19 Two-Dimensional Slope Section Profile and Stability Analysis results for Bench Reduction Trial 2 slope section on US Route 121.

The figure above shows that the slope had an overall Factor of Safety of 1.58. This was a more significant increase in comparison to the first two trials. The weakest failure plane was located on Bench 2 and continued into Backslope 2. No other potential failure planes below a Factor of Safety of 1.75 were observed in this case. This case study slope section with a removal of two benches was found to be structurally stable when modeled.

\subsection{CRSP-2D Simulation Results}

A CRSP-2D model of the slope can be seen in Figure 6.20. The results of simulation runs from all possible release points are shown in Table 6.12. 


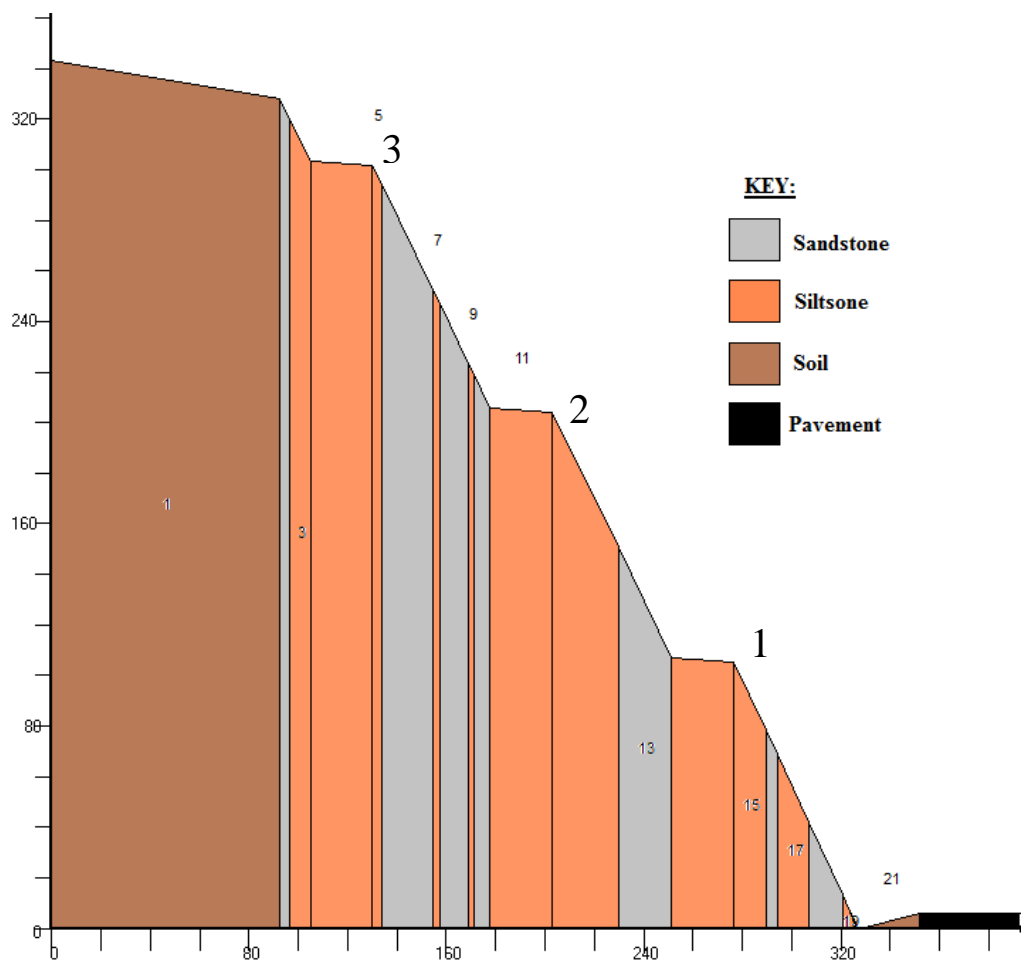

Figure 6.20 Two- Dimensional Slope Section Profile from second bench removal case of slope section of US Route 121 modeled in CRSP-2D

Table 6.12 CRSP-2D Simulation Runs on US Route 121 Case Study Slope: Bench Removal Trial 2

\begin{tabular}{|l|l|l|l|l|l|}
\hline $\begin{array}{l}\text { Rockfall } \\
\text { Release Zone } \\
\text { (Cell \#'s) }\end{array}$ & $\begin{array}{l}\text { Rockfall Release } \\
\text { Zone Description }\end{array}$ & $\begin{array}{l}\text { Rockfall } \\
\text { Material Type } \\
\text { and Density }\end{array}$ & $\begin{array}{l}\text { Rockfall } \\
\text { Diameter } \\
(\mathbf{f t} .)\end{array}$ & $\begin{array}{l}\text { Percentage } \\
\text { Retained Before } \\
\text { Roadway }\end{array}$ & $\begin{array}{l}\text { Average } \\
\text { Runout Past } \\
\text { Ditch (ft.) }\end{array}$ \\
\hline 15 & $\begin{array}{l}3 \text { feet @ top of } \\
\text { Backslope 1 }\end{array}$ & $\begin{array}{l}\text { Soft Bedrock, } \\
165 \mathrm{lb} / \mathrm{ft}^{3}\end{array}$ & 1.0 & $82 \%$ & 14.4 \\
\hline 12 & $\begin{array}{l}3 \text { feet @ top of } \\
\text { Backslope 2 }\end{array}$ & $\begin{array}{l}\text { Soft Bedrock, } \\
165 \mathrm{lb} / \mathrm{ft}^{3}\end{array}$ & 1.0 & $86 \%$ & 18.1 \\
\hline 6 & $\begin{array}{l}3 \text { feet @ mid- } \\
\text { Backslope 3 }\end{array}$ & $\begin{array}{l}\text { Hard Bedrock, } \\
150 \mathrm{lb} / \mathrm{ft}^{3}\end{array}$ & 1.0 & $91 \%$ & 15.7 \\
\hline 5 & $\begin{array}{l}3 \text { feet @ top of } \\
\text { Backslope 3 }\end{array}$ & $\begin{array}{l}\text { Soft Bedrock, } \\
165 \mathrm{lb} / \mathrm{ft}^{3}\end{array}$ & 1.0 & $89 \%$ & 23.9 \\
\hline 2 & $\begin{array}{l}8 \text { feet @ top of } \\
\text { Backslope 4 }\end{array}$ & $\begin{array}{l}\text { Hard Bedrock, } \\
150 \mathrm{lb} / \mathrm{ft}^{3}\end{array}$ & 1.0 & $100 \%$ & $\mathrm{n} / \mathrm{a}$ \\
\hline
\end{tabular}

The results show that this bench reduction case fails at retaining the minimum amount of rockfall from the roadway. The lower portions of the slope, Backslopes 1 and 2, allowed for the highest amount of rockfall to reach the roadway, at $18 \%$ and $14 \%$ respectively. See Appendix V for the 
visual representations of the rockfall trajectories in which greater than $10 \%$ of falling rocks reached the roadway. While most of the release zones are close to $90 \%$ retention, three separate release zones on the slope failed to meet this lower limit of rockfall retention and thus cannot be accepted without additional mitigation approaches. From this point, the transportation agency should conduct a cost analysis to determine if the reduction in excavation costs associated with only constructing three geotechnical benches outweighs the increase in cost of purchasing and installing additional rockfall mitigation devices.

\subsubsection{Bench Removal Feasibility Case Study Trial 3}

Since the second bench removal trial was not found to be adequate at rockfall retention, the final bench removal trial had the objective to determine if the case study slope section of US Route 121 could be structurally stable and safe with only two geotechnical benches and a small increase in ditch width. In an attempt to keep increased excavation costs to a minimum, the ditch width was only increased 4 feet to create a $5 \mathrm{ft}$. ditch bottom and a total width of 29 feet. Observing the rockfall runout results from Trial 3, it was assumed that the $4 \mathrm{ft}$. increase would be adequate in retaining the minimum acceptable amount of falling rocks.

\subsection{SoilVision SVSlope ${ }^{\circledR}$ Results}

The bench that was removed for this trial was the uppermost bench from Trial 2. The remaining two benches were not moved. To account for only have two geotechnical benches for over 300 vertical feet of slope, the bench widths were increased to 35 feet to aid in rockfall mitigation. Figure 6.21 shows the modeled slope for bench removal Trial 3 in SVSlope ${ }^{\circledR}$. 


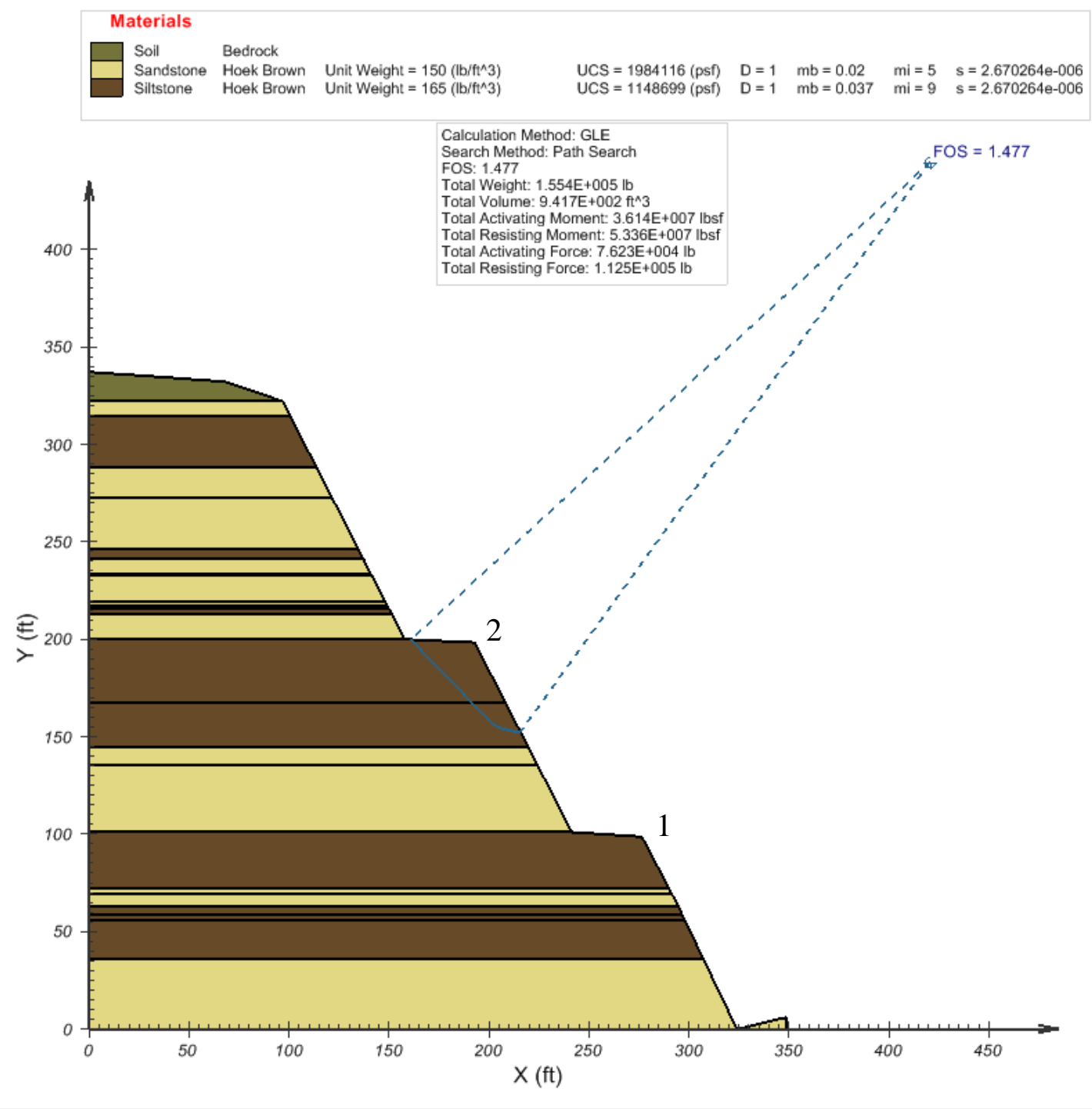

Figure 6.21 Two-Dimensional Slope Section Profile and Stability Analysis results for Bench Reduction Trial 3 slope section on US Route 121.

The figure shows that there was an overall reduction in slope stability for this trial compared to Trial 2, but the Factor of Safety did not drop below the minimum allowable of 1.25. The weakest failure plane was found in Bench 2 and going into Backslope 2, with a Factor of Safety $=1.48$. Four additional Factors of Safety below 1.75 were found in both benches 1 and 2 . Overall, this case study slope section with a removal of all but two benches was found to be structurally stable.

\subsection{CRSP-2D Simulation Results}

Figure 6.22 shows the model of the slope section. As with Trial 2, an RCAD-style ditch was placed at the toe of slope. The ditch width was increased to 29 total feet ( $4 \mathrm{ft}$. flat bottom), compared to the 25 foot ditch from the previous trial ( $1 \mathrm{ft}$. flat bottom). This was designed in an effort to retain a safe percentage of falling rocks. Table 6.13 displays results from all rockfall simulation trials. 


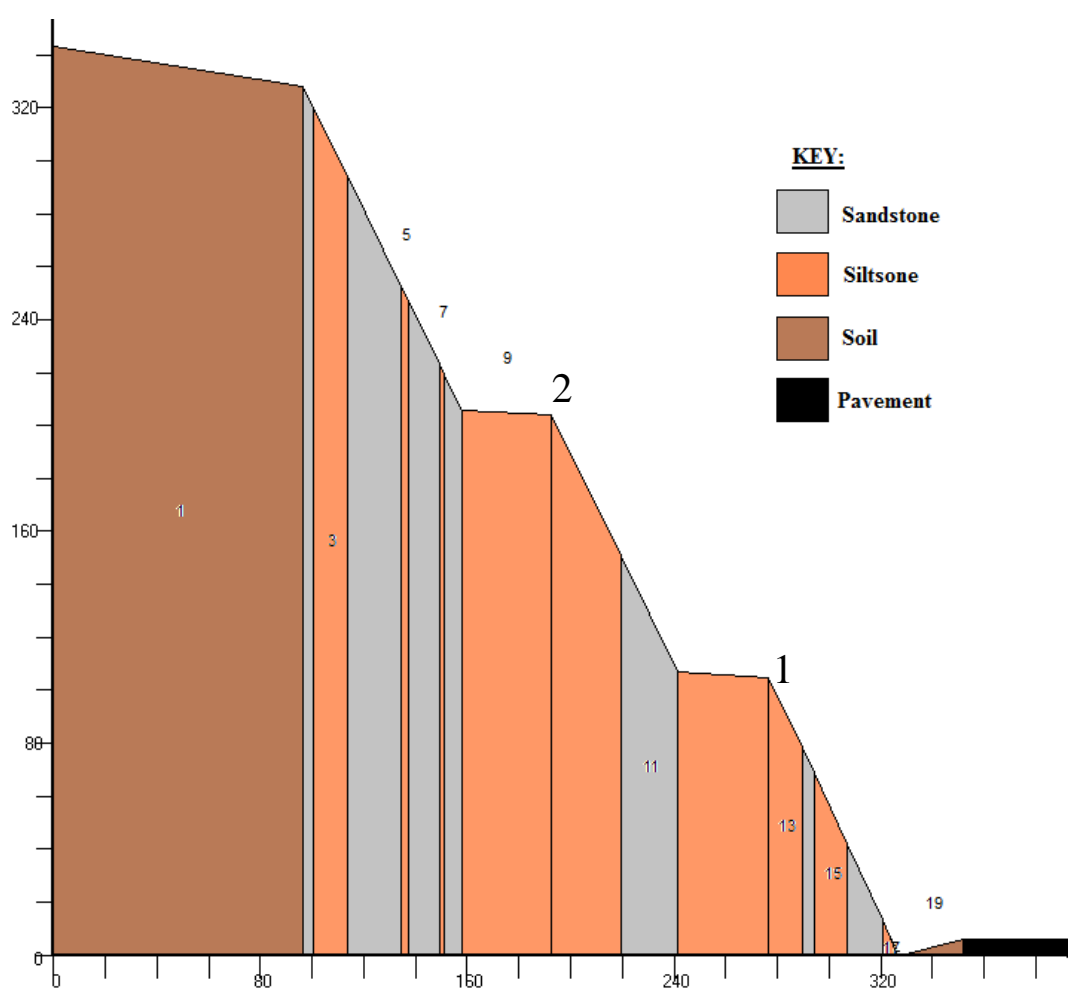

Figure 6.22 Two- Dimensional Slope Section Profile from third bench removal case of slope section of US Route 121 modeled in CRSP-2D

Table 6.13 CRSP-2D Simulation Runs on US Route 121 Case Study Slope: Bench Removal Trial 3

\begin{tabular}{|c|c|c|c|c|c|}
\hline $\begin{array}{c}\text { Rockfall } \\
\text { Release Zone } \\
\text { (Cell \#'s) }\end{array}$ & $\begin{array}{c}\text { Rockfall Release } \\
\text { Zone Description }\end{array}$ & $\begin{array}{c}\text { Rockfall } \\
\text { Material Type } \\
\text { and Density }\end{array}$ & $\begin{array}{c}\text { Rockfall } \\
\text { Diameter } \\
\text { (ft.) }\end{array}$ & $\begin{array}{c}\text { Percentage } \\
\text { Retained Before } \\
\text { Roadway }\end{array}$ & $\begin{array}{c}\text { Average } \\
\text { Runout Past } \\
\text { Ditch (ft.) }\end{array}$ \\
\hline 13 & $\begin{array}{c}3 \text { feet @ top of } \\
\text { Backslope 1 }\end{array}$ & $\begin{array}{c}\text { Soft Bedrock, } \\
165 \mathrm{lb} / \mathrm{ft}^{3}\end{array}$ & 1.0 & $88 \%$ & 13.7 \\
\hline 10 & $\begin{array}{c}3 \text { feet @ top of } \\
\text { Backslope 2 }\end{array}$ & $\begin{array}{c}\text { Soft Bedrock, } \\
165 \mathrm{lb} / \mathrm{ft}^{3}\end{array}$ & 1.0 & $94 \%$ & 31.0 \\
\hline 3 & $\begin{array}{c}3 \text { feet @ mid- } \\
\text { Backslope 3 }\end{array}$ & $\begin{array}{c}\text { Soft Bedrock, } \\
165 \mathrm{lb} / \mathrm{ft}^{3}\end{array}$ & 1.0 & $97 \%$ & 21.2 \\
\hline 2 & $\begin{array}{c}8 \text { feet @ top of } \\
\text { Backslope 4 }\end{array}$ & $\begin{array}{c}\text { Hard Bedrock, } \\
150 \mathrm{lb} / \mathrm{ft}^{3}\end{array}$ & 1.0 & $97 \%$ & 24.2 \\
\hline
\end{tabular}

The table shows that the release zone that caused the lowest percentage of rockfall retention was the top of Backslope 1. This is assumed to be due to the fact that there is only a ditch below this release zone to catch the rockfall (see Appendix V for a visual representation of this rockfall trajectory). With rockfall retention of $88 \%$, minimal additional changes to the geometry will be needed to ensure that this release zone meets the minimum retention requirements. All other release zones produced safe results. 
Overall, the third bench removal trial, reducing the total number of benches on the case study slope section from seven to two, is both structurally stable and statistically safe from rockfall reaching the roadway when modeled with SoilVision SVSlope ${ }^{\circledR}$ and CRSP-2D. Additional bench removal is not feasible with the weaker bedrock types involved in this slope, thus this is the final removal trial.

\subsubsection{US Route 121 Case Study Overall Results}

Table 6.14 US Route 121 Bench Removal Feasibility Case Study Overall Results

\begin{tabular}{|c|c|c|c|c|}
\hline $\begin{array}{c}\text { Bench Reduction } \\
\text { Case }\end{array}$ & $\begin{array}{c}\text { Number of } \\
\text { Geotechnical } \\
\text { Benches on Slope }\end{array}$ & $\begin{array}{c}\text { Rockfall Release } \\
\text { Zone producing } \\
\text { Lowest Retention } \\
\text { Percentage }\end{array}$ & $\begin{array}{c}\text { Lowest On- } \\
\text { Slope } \\
\text { Retention } \\
\text { Percentage }\end{array}$ & $\begin{array}{c}\text { Stability Factor of } \\
\text { Safety }\end{array}$ \\
\hline As-Built & 6 & Backslope 2 & $92 \%$ & 1.26 \\
\hline 1 & 5 & Backslope 2 & $93 \%$ & 1.34 \\
\hline 2 & 3 & Backslope 1 & $82 \%$ & 1.58 \\
\hline 3 & 2 & Backslope 1 & $88 \%$ & 1.48 \\
\hline
\end{tabular}

One observation made from both case study results, shown in Table 6.14 is that the rockfall release zones located lower on the slope (Backslopes 1 and 2) tended to have the lowest on-slope retention percentage. While rocks falling from these heights have lower energy and velocity at the bottom of the slope compared to rocks falling from the upper backslopes, they also have fewer benches for potential retention prior to reaching the roadway. Thus, it is important to have a properly designed catchment ditch at the toe of slope to ensure adequate retention of rocks from these lower release zones.

\subsection{Excavation Reduction Examples}

Though actual material volume and monetary reduction costs were unobtainable for this research, assumptions can be made based off of modeling observations. To determine if bench reduction on a rock cut slope is an economical benefit in terms of excavation, area calculations were conducted in AutoCAD Civil 3D 2012. Figure 6.23 shows the overlay of the as-built slope and the slope from Bench Removal Trial 3 from the US Route 48 case study. The potential reduction in excavated cross-sectional area between these two models, highlighted in red, is approximately $3670 \mathrm{ft}^{2}$ per foot of slope length along roadway. Figure 6.24 shows the overlay of the as-built slope and the slope from Bench Removal Trial 3 from the US Route 121 case study. The potential reduction in excavated cross-sectional area between these two models, highlighted in red, is approximately $4600 \mathrm{ft}^{2}$ per foot of slope length along roadway. Note that the excavation required to construct an RCAD-style ditch is approximately $100 \mathrm{ft}^{2}$ per foot of slope length for each slope, which was not factored into the calculation. While these are relatively small reductions, it shows that bench reduction has a direct relationship with material excavation reduction, and thus it can be assumed that removing benches aids in stability, safety, and cost efficiency. 


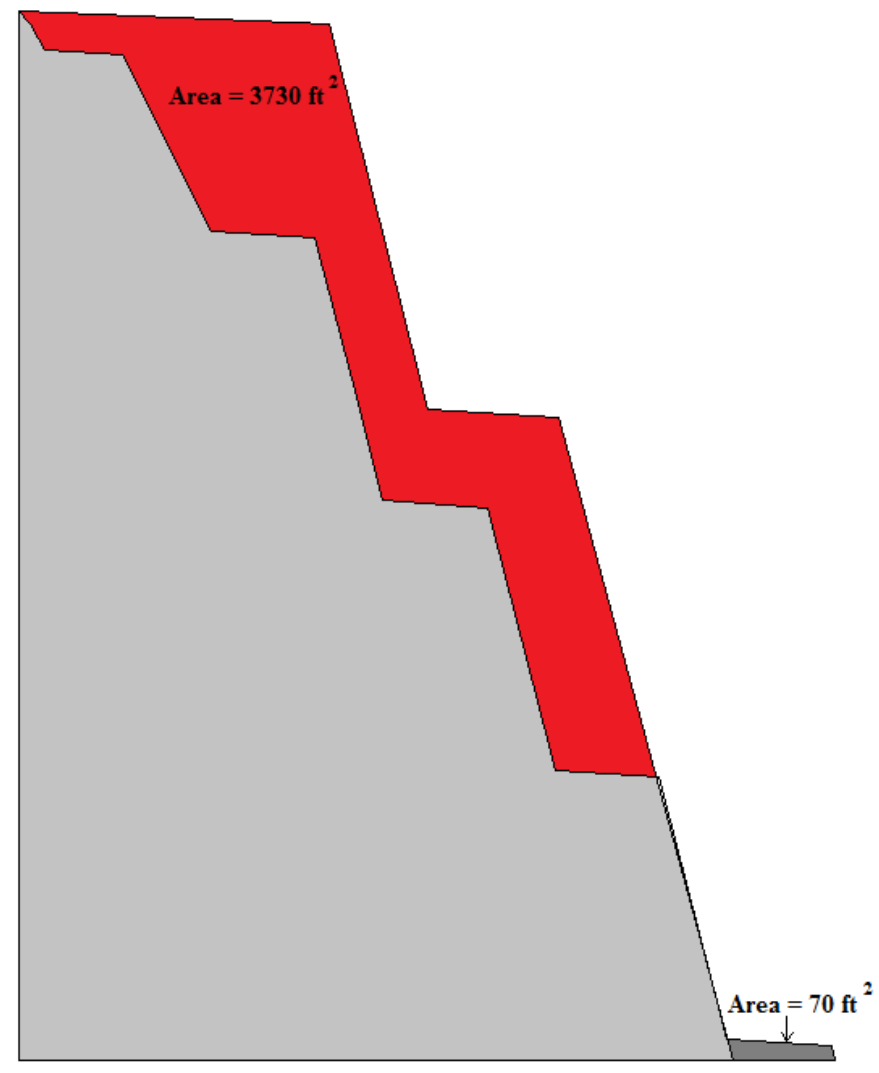

Figure 6.23 Cross-Sectional display of excavation reduction associated with bench removal on case study section of US Route 48.

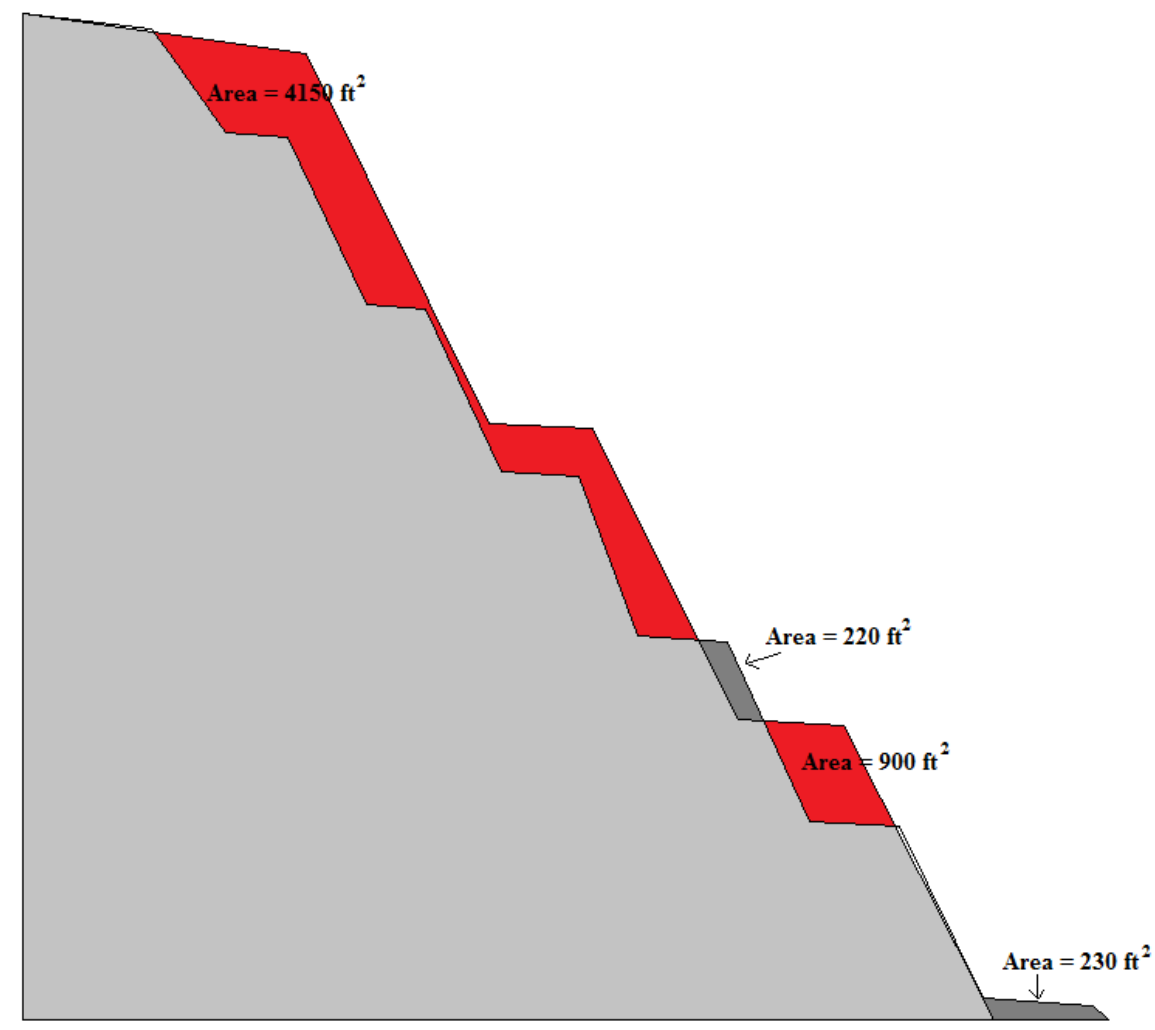

Figure 6.24 Cross- Sectional display of excavation reduction associated with bench removal on case study section of US Route 121. 


\section{CONCLUSIONS AND RECOMMENDATIONS}

This research included the development and testing of a Rockfall Hazard Rating System for new cut slopes, a comprehensive analysis of WVDOT's rock cut slope design guidelines with respect to rockfall mitigation, and two case studies to determine if a reduction in bench design on rock cut slopes is both stable and safe. The following are the key findings:

- The two objectives of designing a rock cut slope is for the slope to be structurally stable and safe to roadway users below. RHRS provides an initial rating through observations based on both of these parameters. SoilVision SVSlope ${ }^{\circledR}$ determines if the slope is or will be structurally stable. CRSP-2D determines if the slope is statistically safe from rockfall for roadway users.

- RHRS for new cut slopes assists state transportation agencies in multiple ways. It provides a way to organize and monitor all rock cut slopes within the state, helps allocate resources to the most hazardous slopes, and provides an aid in determining what aspects of current design practices that cause the highest rockfall hazard potential.

- The use of a GIS mapping system, such as ArcGIS, allows for an interactive and easily updateable RHRS database. Additionally, the built-in Jenks Classification algorithm automatically categorizes slopes based on their ratings without any additional calculations done by the user.

- Based on rockfall simulation modeling, WVDOT's current design guidelines for rock cut slopes (WV DD-403) are found adequate with a few modifications and recommendations:

- When benches are designed as a rockfall catchment device, they should never be less than 25 feet wide. The current $20 \mathrm{ft}$. minimum width listed in WV DD-403 does not allow for the minimum retention of $90 \%$ rockfall on-slope.

- In place of a rockfall catchment bench 5 feet above the toe of slope, implement an RCAD-style catchment ditch system following the designs of Ritchie and Oregon DOT (ODOT, 2001).

- In terms of rockfall mitigation, steeper slopes are better at retaining rockfall on benches and reducing runout past toe of slope. Always ensure slope is structurally stable at a steeper angle before implementing, however.

- The number of benches on a slope over 200 feet in height can be significantly reduced with the proper design. The iterative use of finite element numerical modeling software and rockfall simulation modeling can determine exactly how many benches can feasibly and safely be removed.

- WVDOT's current design directives are both structurally stable and statistically safe for roadway users, so the objectives for bench reduction is to reduce excavation costs while maintaining (or increasing) stability and safety of the slope. This objective was found to be achievable in case studies.

$\circ$ While not currently in the realm of WV DD-403 guidelines, the borehole drilling process for cut slope design should be re-assessed to ensure more comprehensive borehole logs. Gaps in borehole information can create inaccurate assumptions in slope stratigraphy, which may lead to unstable or unsafe slopes.

- While conducting this research, opportunities were found for further research to be conducted on the following topics:

○ Conduct a more thorough and comprehensive analysis with the altered version of Rockfall Hazard Rating System for new slopes with slope sites throughout West Virginia to determine the accuracy of the alterations. 
- The use of rockfall simulation software to determine the effects of infilling of eroded material on rock cut slope benches on rockfall behavior.

$\circ$ Testing the effectiveness of additional mitigation techniques such as barriers and netting on rockfall mitigation using rockfall simulation software.

- Determining whether the two-dimensional or three-dimensional version of Colorado Rockfall Simulation Program produces more accurate results. 


\section{REFERENCES}

Anderson, S.A., DeMarco, J.M. (2013). "Use of Rockfall Rating Systems in the Design of New Slopes." GeoChallenges: Rising to the Geotechnical Challenges of Colorado, No. 7, 3753. American Society of Civil Engineers.

Andrew, R., Hume, H., Bartingale, R. (2012). CRSP-3D User's Manual (FHWA-CFL/TD-12007). Colorado: FHWA- Central Federal Lands Highway Division

Appalachian Regional Commission. (2013). “Appalachian Development Highway System.” Retrieved from http:// http://www.arc.gov/adhs/.

Colorado Department of Transportation. (2014). 2014 CDOT Construction Manual. CDOT.

Das, B.M. (2006). Principles of Geotechnical Engineering ( $7^{\text {th }}$ ed.). Canada: Nelson Education Ltd.

Esri. (2004). "FAQ: What is the Jenks optimization method?" (Article ID 26442). Knowledge Base - Technical Articles. Redlands, CA: Esri.

Esri. (2012). What is GIS?. Redlands, CA: Esri.

Fredlund, D.G., Krahn, J., Pufahl, D.E. (1981). “The Relationship between Limit Equilibrium Slope Stability Methods." Proceedings of the International Conference on Soil Mechanics and Foundation Engineering, Vol. 3, 409 - 416. Stockholm, Sweden.

Google, Inc. (2014). Google Earth (Version 7) [Computer program]. Available at http://www.google.com/earth/download/ge/agree.html.

Hoek, E., Carranza-Torres, C., Corkum, B. (2002). Hoek-Brown Failure Criterion-2002 Edition. RocScience Inc.

Jaboyedoff, M., Labiouse, V. (2003). International Society for Rock Mechanics. Preliminary assessment of rockfall hazard based on GIS data. Swiss Federal Institute of Technology. Quanterra, Lausanne, Switzerland.

Jenks, G.F. (1967). “The Data Model Concept in Statistical Mapping.” International Yearbook of Cartography 7, 186-190. George Phillip.

Jones, C.L., Higgins, J.D., Andrew, R.D. (2000). Colorado Rockfall Simulation Program Version 4.0 (CDOT-SYMB-CGS-99-1). Colorado Department of Transportation.

Kulbacki, M.A. (2014). "Slope Stability and Alternative Design Methodology for Highway Rock Cut Slopes in West Virginia.” MSCE Thesis.

Marinos, V., Marinos, P., Hoek, E. (2005). "The geological strength index: applications and limitations." Bulletin of Engineering Geology and the Environment, Vol. 64, Issue 1, 5565. Athens, Greece.

Myers, J.D. (2010). "Strike and dip of a tabular geologic unit." JPEG. Retrieved from http://http://www.gg.uwyo.edu/.

Ohio Department of Transportation. (2011). Rock Slope Design Guide. Columbus, OH.

Ohio Department of Transportation: Office of Research and Development. (2007). Landslide Hazard Rating Matrix and Database: Volume 1 (State Job No. 134165). Akron, OH. University of Akron ODOT, 2001

Oregon Department of Transportation. (2001). Rockfall Catchment Area Design Guide Final Report (FHWA-OR-RD-02-04). Washington, DC: Federal Highway Administration. 
Oregon Department of Transportation: Technical Services Branch: Geo-Environmental Section. (2012). Geotechnical Design Manual Volume 1. Salem, OR.

Pennsylvania Department of Transportation. (2007). Publication 293 Geotechnical Manual. Harrisburg, PA: PennDOT.

Pentz, J.D. (2014). "Use of Colorado Rockfall Simulation 3-D to Determine Feasibility of Geotechnical Bench Reduction on Highway Rock Cut Slopes in West Virginia.”, MSCE Thesis.

Pierson, L.A. (1991). Rockfall Hazard Rating System (FHWA-OR-GT-92-05). Washington, DC: Federal Highway Administration.

Rahardjo, H., Fredlund, D.G. (1984). "General limit equilibrium method for lateral earth force." Canadian Geotechnical Journal 21, 166 - 175.

Ritchie, A.M. (1963). "Evaluation of Rockfall and Its Control.” Highway Research Record (Vol. 17). Washington, DC: Highway Research Board.

Sjöberg, J. (1997). Estimating Rock Mass Strength using the Hoek-Brown Failure Criterion and Rock Mass Classification. Internal Report: Division of Highways, (SE-971 87 Lulea, Lulea University of Technology).

SoilVision Systems, Ltd. (2011). "Public Release of SVSlope ${ }^{\circledR}$ 3D - A New Standard in 3D Slope Stability Analysis." Saskatoon, Canada.

The State of Montana Department of Transportation. (2008). MDT Geotechnical Manual. MDT.

West Virginia Department of Transportation, Division of Highways. (2006). Design Directives: Guide for Design in Cut Sections Through Bedrock (DD-403). Charleston, WV: WVDOH.

WV GIS Technical Center (2014). WV State GIS Data Clearinghouse. Retrieved from http://wvgis.wvu.edu/data/.

Zhao, J. (2010). "Chapter 4: Properties of Rock Materials." Rock Mechanics for Civil Engineers. Swiss Federal Institute of Technology. 


\section{APPENDICES}

\section{Appendix I: Original Rockfall Hazard Rating System Descriptions}

All of the following information was taken directly from "The Rockfall Hazard Rating System" by Lawrence A. Pierson (Pierson, 1991).

\begin{tabular}{|c|c|c|c|c|c|c|}
\hline \multirow{2}{*}{\multicolumn{3}{|c|}{ Category }} & \multicolumn{4}{|c|}{ Rating Criteria and Score } \\
\hline & & & 3 Points & 9 Points & 27 Points & 81 Points \\
\hline \multicolumn{3}{|c|}{ Slope Height } & 25 Feet & 50 Feet & 75 Feet & 100 Feet \\
\hline \multicolumn{3}{|c|}{ Ditch Effectiveness } & Good Catchment & $\begin{array}{l}\text { Moderate } \\
\text { Catchment }\end{array}$ & $\begin{array}{l}\text { Limited } \\
\text { Catchment }\end{array}$ & No Catchment \\
\hline \multicolumn{3}{|c|}{ Average Vehicle Risk } & $25 \%$ of the time & $50 \%$ of the time & $75 \%$ of the time & $100 \%$ of the time \\
\hline \multicolumn{3}{|c|}{$\begin{array}{c}\text { Percent of Decision Sight } \\
\text { Distance }\end{array}$} & $\begin{array}{l}\text { Adequate sight } \\
\text { distance, } 100 \% \\
\text { of low design } \\
\text { value }\end{array}$ & $\begin{array}{l}\text { Moderate sight } \\
\text { distance, } 80 \% \text { of } \\
\text { low design value }\end{array}$ & $\begin{array}{l}\text { Limited sight } \\
\text { distance, } 60 \% \text { of } \\
\text { low design value }\end{array}$ & $\begin{array}{l}\text { Very limited } \\
\text { sight distance, } \\
40 \% \text { of low } \\
\text { design value }\end{array}$ \\
\hline \multirow{4}{*}{ 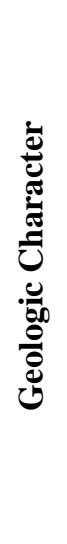 } & \multirow{2}{*}{ चٓ } & $\begin{array}{l}\text { Structural } \\
\text { Condition }\end{array}$ & $\begin{array}{l}\text { Discontinuous } \\
\text { joints, favorable } \\
\text { orientation }\end{array}$ & $\begin{array}{l}\text { Discontinuous } \\
\text { joints, random } \\
\text { orientation }\end{array}$ & $\begin{array}{l}\text { Discontinuous } \\
\text { joints, adverse } \\
\text { orientation }\end{array}$ & $\begin{array}{l}\text { Continuous } \\
\text { joints, adverse } \\
\text { orientation }\end{array}$ \\
\hline & & $\begin{array}{l}\text { Rock } \\
\text { Friction }\end{array}$ & Rough, irregular & Undulating & Planar & $\begin{array}{l}\text { Clay infilling, or } \\
\text { slickensided }\end{array}$ \\
\hline & \multirow{2}{*}{ שֶّ } & $\begin{array}{l}\text { Structural } \\
\text { Condition }\end{array}$ & $\begin{array}{l}\text { Few differential } \\
\text { erosion features }\end{array}$ & $\begin{array}{l}\text { Occasional } \\
\text { erosion features }\end{array}$ & $\begin{array}{l}\text { Many erosion } \\
\text { features }\end{array}$ & $\begin{array}{l}\text { Major erosion } \\
\text { features }\end{array}$ \\
\hline & & $\begin{array}{l}\text { Difference } \\
\text { in Erosion } \\
\text { Rates }\end{array}$ & Small difference & $\begin{array}{l}\text { Moderate } \\
\text { difference }\end{array}$ & Large difference & $\begin{array}{l}\text { Extreme } \\
\text { difference }\end{array}$ \\
\hline \multicolumn{3}{|c|}{$\begin{array}{l}\text { Block Size / Volume of } \\
\text { Rockfall Event }\end{array}$} & $\begin{array}{l}1 \text { Foot / } 3 \text { Cubic } \\
\text { Yards }\end{array}$ & $\begin{array}{l}2 \text { Feet / } 6 \text { Cubic } \\
\text { Yards }\end{array}$ & $\begin{array}{l}3 \text { Feet / } 9 \text { Cubic } \\
\text { Yards }\end{array}$ & $\begin{array}{l}4 \text { Feet / } 12 \text { Cubic } \\
\text { Yards }\end{array}$ \\
\hline \multicolumn{3}{|c|}{$\begin{array}{c}\text { Climate and Presence of } \\
\text { Water on Slope }\end{array}$} & $\begin{array}{l}\text { Low to moderate } \\
\text { precipitation; no } \\
\text { freezing periods; } \\
\text { no water on } \\
\text { slope }\end{array}$ & $\begin{array}{l}\text { Moderate } \\
\text { precipitation or } \\
\text { short freezing } \\
\text { periods or } \\
\text { intermittent } \\
\text { water on slope }\end{array}$ & $\begin{array}{l}\text { High } \\
\text { precipitation or } \\
\text { long freezing } \\
\text { periods or } \\
\text { continual water } \\
\text { on slope }\end{array}$ & $\begin{array}{l}\text { High } \\
\text { precipitation and } \\
\text { long freezing } \\
\text { periods or } \\
\text { continual water } \\
\text { on slope and long } \\
\text { freezing periods }\end{array}$ \\
\hline \multicolumn{3}{|c|}{ Rockfall History } & Few falls & Occasional falls & Many falls & Constant falls \\
\hline
\end{tabular}




\section{Rating Definitions:}

1. Slope Height: This item represents the vertical height of the slope. Rocks on high slopes have more potential energy than rocks on lower slopes, thus they present a greater hazard and receive a higher rating. Measurement is to the highest point from which rockfall is expected. If rocks are coming from the natural slope above the cut, use the cut height plus the additional slope height (vertical distance) is measured.

2. Ditch Effectiveness: The effectiveness of a ditch is measured by its ability to restrict falling rock from reaching the roadway. In estimating the ditch effectiveness, the rater should consider several factors, such as slope height and angle, ditch width, depth and shape, anticipated quantity of rockfall per event, and impact of slope irregularities on falling rocks. Evaluating the effect of slope irregularities is especially important. These features can completely negate the benefits expected from a fallout area. Valuable information on ditch performance can be obtained from the maintenance personnel. Scoring should be consistent with the following descriptions:

a. Good catchment - all or nearly all falling rocks are retained in the catch ditch.

b. Moderate catchment - Falling rocks occasionally reach the roadway.

c. Limited catchment - Falling rocks frequently reach the roadway.

d. No catchment - No ditch or ditch is totally ineffective. All or nearly all falling rocks reach the roadway.

3. Average Vehicle Risk (AVR): This category measures the percentage of time that a vehicle will be present in the rockfall hazard zone. The percentage is obtained by using an equation (shown below) based on slope length, average daily traffic (ADT), and posted speed limit at the site. A rating of $100 \%$ means that on average a car will be within the defined rockfall section $100 \%$ of the time. Where high ADT's or longer slope lengths exist, values greater than $100 \%$ will result. When this occurs it means that at any particular time more than one vehicle is present within the measured section. The AVR directly relates to the potential hazard as well as the significance of the route. The equation used is:

$$
\frac{A D T\left(\frac{\text { cars }}{\text { day }}\right) * \text { Slope Length (miles) } / 24\left(\frac{\text { hours }}{\text { day }}\right)}{\text { Posted Speed Limit (M.P.H.) }} * 100 \%=A V R
$$

4. Percent of Decision Sight Distance (DSD): The DSD is used to determine the length of roadway in feet a driver must have to make a complex or instantaneous decision. The DSD is critical when obstacles on the road are difficult to perceive, or when unexpected or unusual or unusual maneuvers are required. Throughout a rockfall section the actual sight distance can change appreciably. Horizontal and vertical highway curves along with obstructions such as rock outcrops and roadside vegetation can severely limit a driver's ability to notice a rock on the road.

The decision sight distance recommended by AASHTO can be determined from the table below. The relationships between decision sight distance and the posted speed limit were modified from Table III-3 of AASHTO's "Policy on Geometric Design of Highways and Streets." The distances listed represent the lower design value. The posted speed limit through the rockfall section should be used. 


\begin{tabular}{|c|c|}
\hline Posted Speed Limit (M.P.H.) & Decision Sight Distance (ft.) \\
\hline $\mathbf{3 0}$ & 450 \\
\hline $\mathbf{4 0}$ & 600 \\
\hline $\mathbf{5 0}$ & 750 \\
\hline $\mathbf{6 0}$ & 1000 \\
\hline $\mathbf{7 0}$ & 1100 \\
\hline
\end{tabular}

Once determined, these two values can be submitted into the following equation to calculate the "Percent of Decision Sight Distance."

$$
\frac{\text { Actual Sight Distance }}{\text { Decision Sight Distance }} * 100 \%=\ldots \%
$$

5. Roadway Width: This dimension, measured perpendicular to the highway centerline from edge of pavement to edge of pavement, represents the available maneuvering room to avoid a rockfall. This measurement should be the minimum width when the roadway width is not constant. On divided roadways only the paved portion available to the driver should be measured.

6. and 7. A slope's geologic conditions are evaluated with these categories. Use the Case 1 categories for slopes where joints, bedding planes, or other discontinuities, are the dominant feature of the slope that leads to rockfall. Case 2 is used for slopes where differential erosion or oversteepening is the dominant condition that controls rockfall. The following is a description of these categories:

a. Geologic Character - Case 1

i. Structural Condition: "Adverse as used here refers to joints that allow block, wedge, planar or toppling failures. "Continuous" refers to joints greater than 10 feet in length.

1. Discontinuous Joints, Favorable Orientation - Slope contains jointed rock with no adversely oriented joints, bedding planes, etc.

2. Discontinuous Joints, Random Orientation - Slope contains randomly oriented joints creating a variable pattern. The slope is likely to have some scattered blocks with adversely oriented joints but no dominant adverse pattern is present.

3. Discontinuous Joints, Adverse Orientation - Rock slope exhibits a prominent joint pattern, bedding plane, or other discontinuity, with an adverse orientation. These features have less than 10 feet of continuous length.

4. Continuous Joints, Adverse Orientation - Rock slope exhibits a dominant joint patter, bedding plane, or other discontinuity, with an adverse orientation and greater than 10 feet in length.

ii. Rock Friction: This parameter directly relates to the potential for a block to move relative to another. Friction along a joint, bedding plane, or other discontinuity is governed by the macro and micro roughness of the surfaces. Noting the failure angles from previous rockfall on a slope can aid in estimating general rock friction along discontinuities. 
1. Rough, Irregular - The surface of the joints are rough and the joint planes are irregular enough to cause interlocking. This macro and micro roughness provides an optimal friction situation.

2. Undulating - Macro rough but without the interlocking ability.

3. Planar - Macro smooth and micro rough joint surfaces. Friction is derived principally from the roughness of the rock surface.

4. Clay infilling, or slickensides - Low friction materials, such as clay, separate the rock surfaces negating any micro or macro roughness of the joint planes. Slickensided joints can also have a very low friction angle and may belong in this category.

b. Geologic Character - Case 2

i. Structural Condition: Case 2 is used for slopes where differential erosion or oversteepening is the dominant condition that leads to rockfall. Erosion features include oversteepened slopes, unsupported rock units or exposed resistant rocks on a slope that may eventually lead to a rockfall event. Rockfall is caused by a loss of support either locally or throughout the slope. Common slopes that are susceptible to this condition are: layered units containing more easily weathered layers that when eroded undermine more durable rocks; talus slopes; highly variable units such as conglomerates, mudflows, rock/soil slopes etc. that weather allowing resistant rocks and blocks to fall as the matrix material is eroded.

1. Few differential erosion features - Minor differential erosion features that are not distributed throughout the slope.

2. Occasional Erosion Features - Minor differential erosion features that are widely distributed throughout the slope.

3. Many Erosion Features - Differential erosion features are large and numerous throughout the slope.

4. Major Erosion Features - Sever cases such as dangerous, erosioncreated overhangs; or significantly oversteepened soil/rock slopes or talus slopes.

ii. Difference in Erosion Rates: The rate of erosion on a Case 2 slope directly relates to the potential for a future rockfall event. The degree of hazard caused by erosion and thus the score given this category should reflect how quickly erosion is occurring; the size of rocks, blocks, or units being exposed; the frequency of rockfall events; and the amount of material released during an event.

1. Small difference - Erosion features take many years to develop. Slopes that are near equilibrium with their environment are covered by this category.

2. Moderate Difference - The difference in erosion rates allows erosion features to develop over a few years.

3. Large Difference - The difference in erosion rates is such that noticeable changes in the slope develop annually.

4. Extreme Difference - The difference in erosion rates allows rapid development of erosion features.

Only one set of scores, either Case 1 or Case 2, is included in a slope's rating. In some instances it may be difficult to determine which Case to use. In those situations, both Cases may be rated but only the scores from the highest scored Case are recorded. 
8. Block Size or Quantity of Rockfall Per Event: This measurement should be representative of whichever type of rockfall event is most likely to occur. A decision on which to use can be determined from the maintenance history or estimated from observed conditions when no history is available. This measurement will also be beneficial in determine remedial measures.

9. Climate and Presence of Water on Slope: Water and freeze/thaw cycles both contribute to the weathering and movement of rock materials. If water is known to flow continually or intermittently from the slope it is rated accordingly. The impact of freeze/thaw cycles can be interpreted from knowledge of the freezing conditions and its effects at the site. The criteria for this category should be adjusted to fit the agencies' regional conditions to assure proper score separation.

10. Rockfall History: This information is best obtained from the maintenance person responsible for the slope. This information is an important check on the potential for future rockfalls.

a. Few falls - Rockfalls have occurred several times according to historical information but are not a persistent problem. If rockfall only occurs a few times a year or less, or only during severe storms, this category should be used. This category is also used if no rockfall history data is available.

b. Occasional Falls - Rockfall occurs regularly. Rockfall can be expected several times per year and during most storms.

c. Many Falls - Typically rockfall occurs frequently during a certain season, such as the winter or spring wet period, or the winter freeze-thaw, etc. This category is for sites where frequent rockfalls occur during a certain season and is not a significant problem during the rest of the year. This category may also be used where sever rockfall events have occurred.

d. Constant Falls - Rockfalls occur frequently throughout the year. This category is also for sites where severe rockfall events are common. 


\section{Appendix II: RHRS Case Study}

Location 1: US Route 48, Westbound Lane

County: Grant

Coordinates: (39.130735, -79.055843)

RHRS Results for Location 1

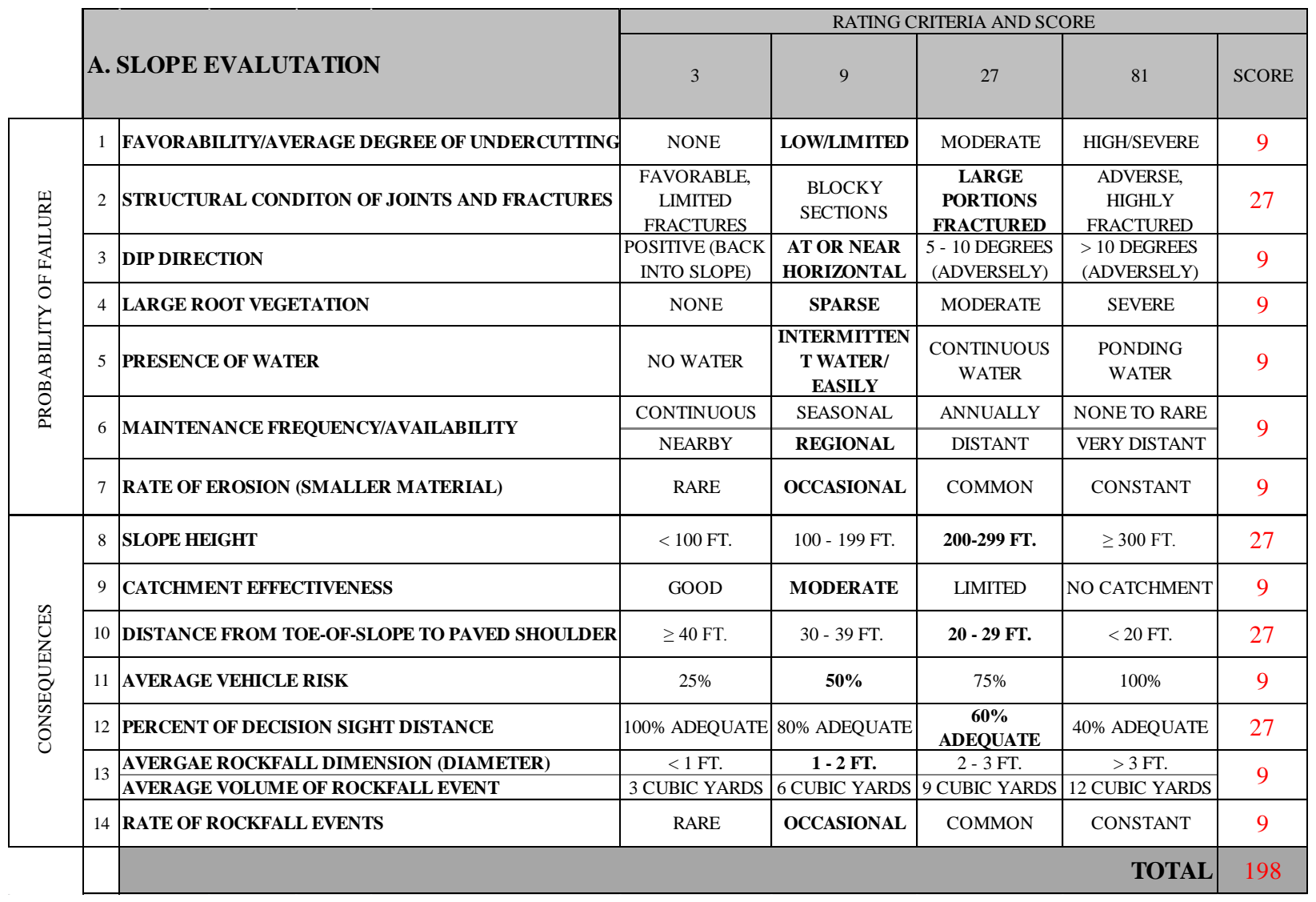

Field Notes Associated with the RHRS Scores for Location 1

\begin{tabular}{|c|l|}
\hline Category \# & Note \\
\hline 2 & Highly fractured faces on about 50\% of backslopes. (See Photo 1) \\
\hline 3 & Bedrock layers appeared flat or dipping slightly away from roadway. \\
\hline 4 & A few small shrubs located on upper benches. (See Photo 2 ) \\
\hline 8 & Total height $=$ approximately 230 feet \\
\hline 9 & $\begin{array}{l}\text { Small catchment ditch and jersey barrier present; } 2 \text { rocks between jersey barrier and } \\
\text { highway. (See Photo } 3 \text { ) }\end{array}$ \\
\hline 10 & Distance $=24$ feet \\
\hline 11 & Taken from WVDOT website, Average Daily Traffic $=$ approximately 4500 \\
\hline 12 & Estimated minimum Decision Sight Distance $=600$ feet \\
\hline & \\
\hline
\end{tabular}


Photographs:

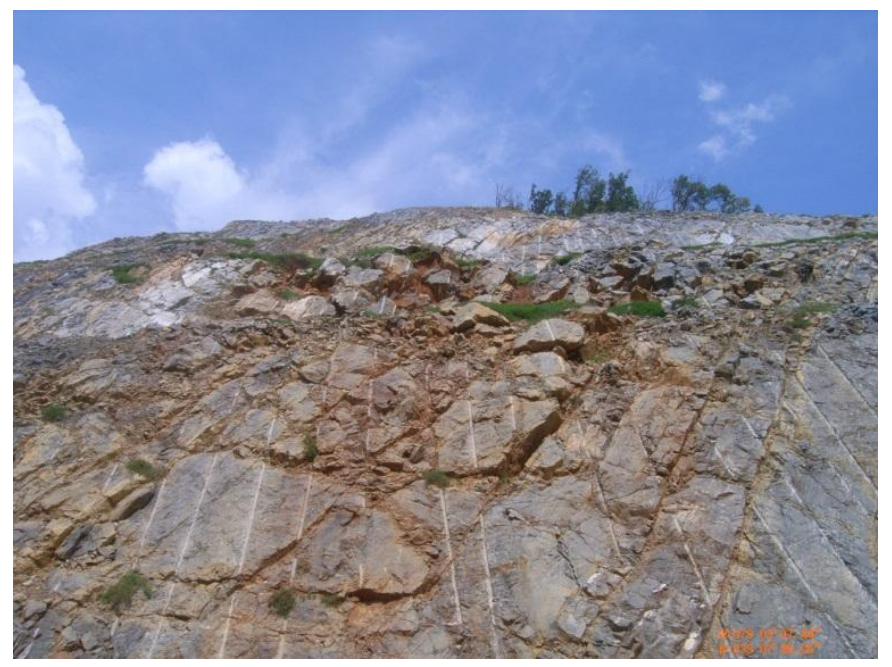

Photo 1: Fractured backslope face with clay infilling at Location 1.

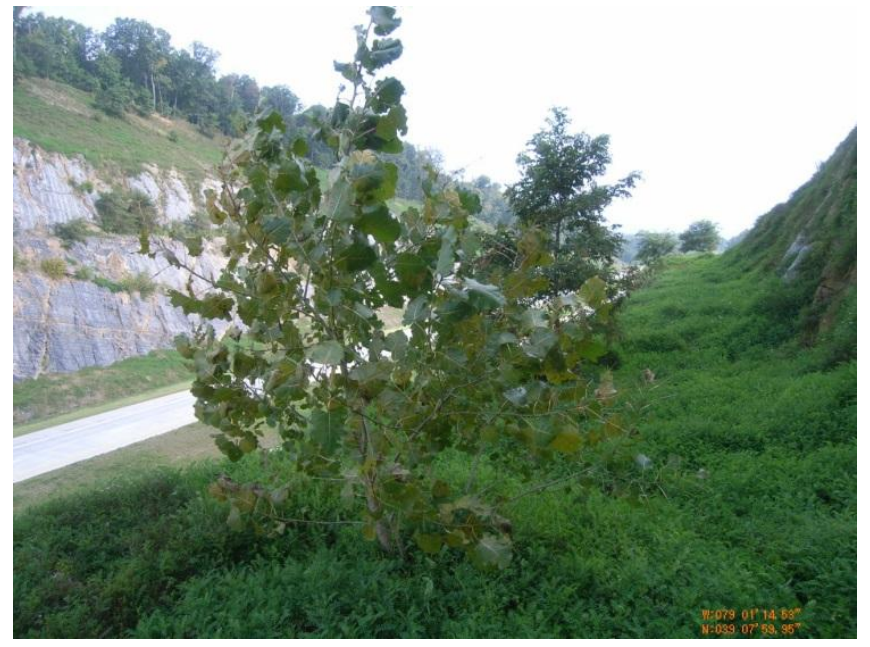

Photo 2: Shrubbery on bench at Location 1.

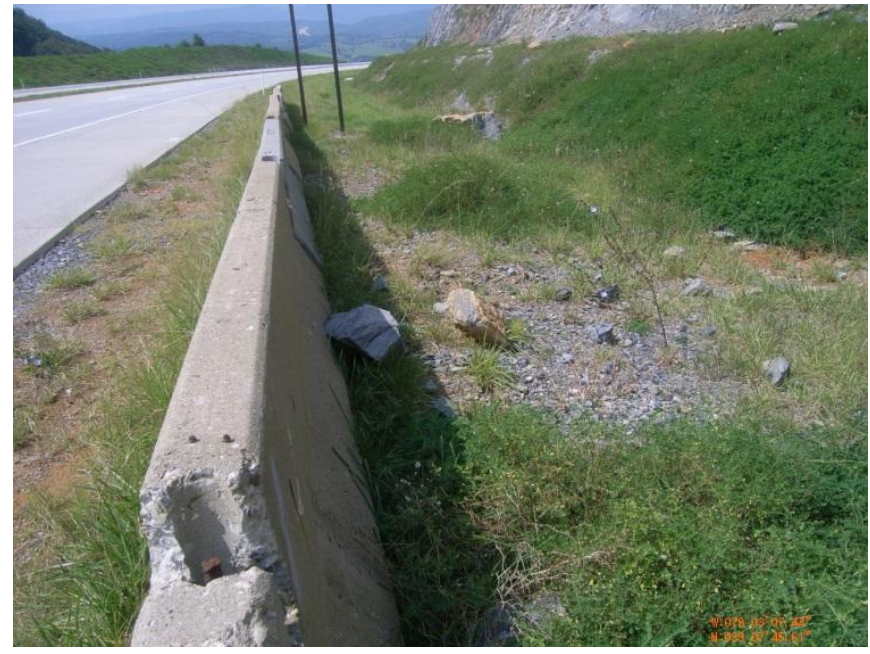

Photo 3: Jersey barrier and small catchment ditch at toe of slope at Location 1. 


\section{Location 2: US Route 121, Southbound Lane}

County: Raleigh

Coordinates: (37.669250, -81.333462)

RHRS Results for Location 2

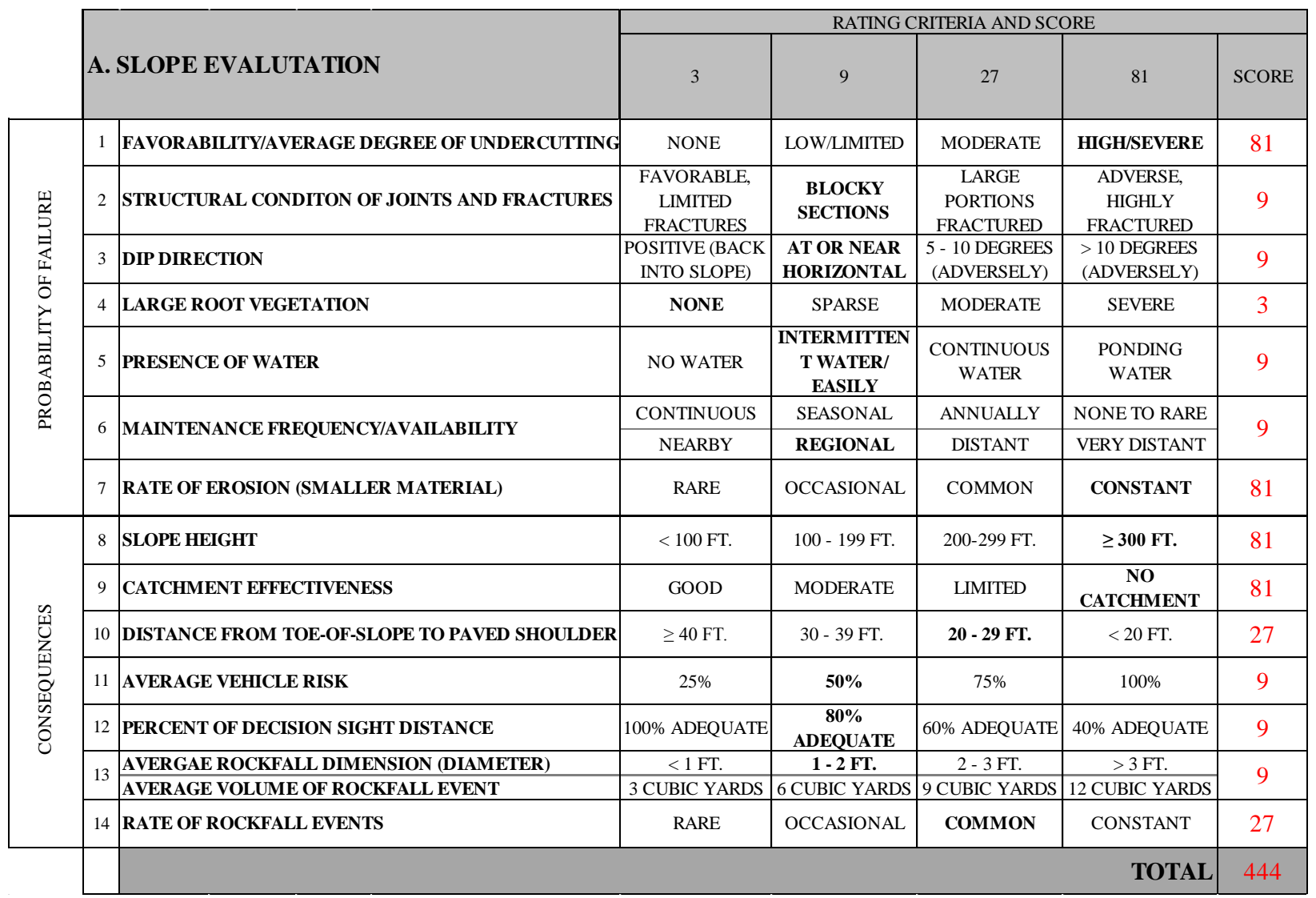

Field Notes Associated with RHRS Scores for Location 2

\begin{tabular}{|c|l|}
\hline Category \# & Note \\
\hline 1 & Undercuts already over 1 foot in depth, slope only two years old. (See Photo 1) \\
\hline 7 & Siltstone layers eroding at a visible rate. (See Photo 2) \\
\hline 8 & Total slope height $=$ approximately 320 feet. \\
\hline 9 & No distinguishable catchment area at toe of slope. \\
\hline 10 & Distance $=25$ feet. \\
\hline 11 & Taken from WVDOT website, Average Daily Traffic $=5000$. \\
\hline 12 & Estimated minimum Decision Sight Distance $=800$ feet. \\
\hline
\end{tabular}


Photographs:

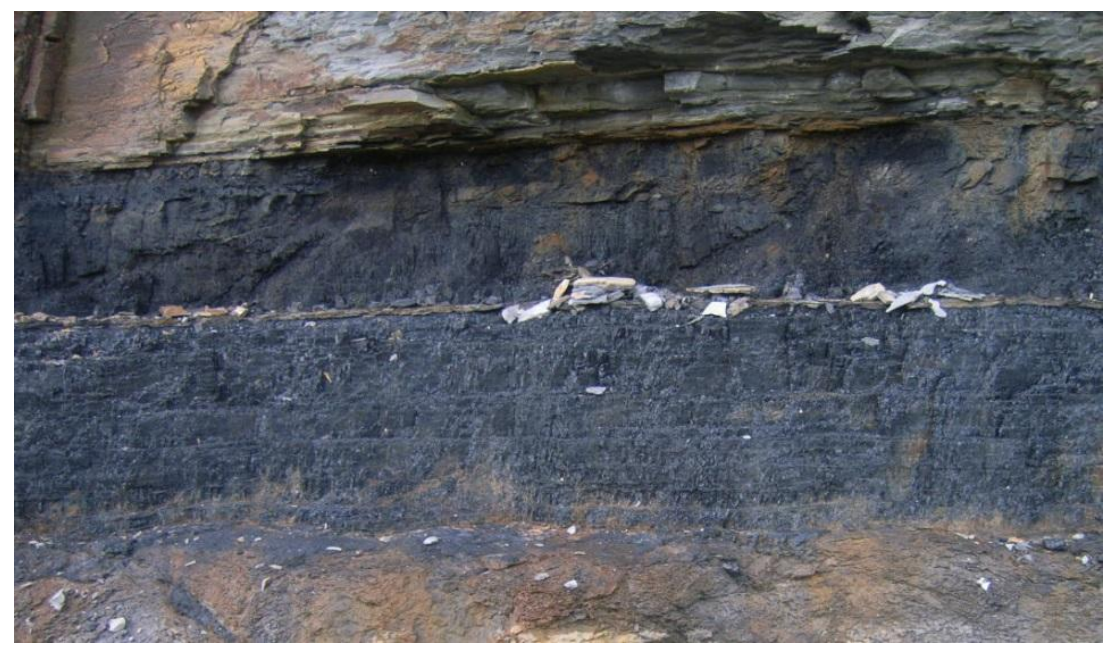

Photo 1: Large undercut above a coal seam at Location 2.

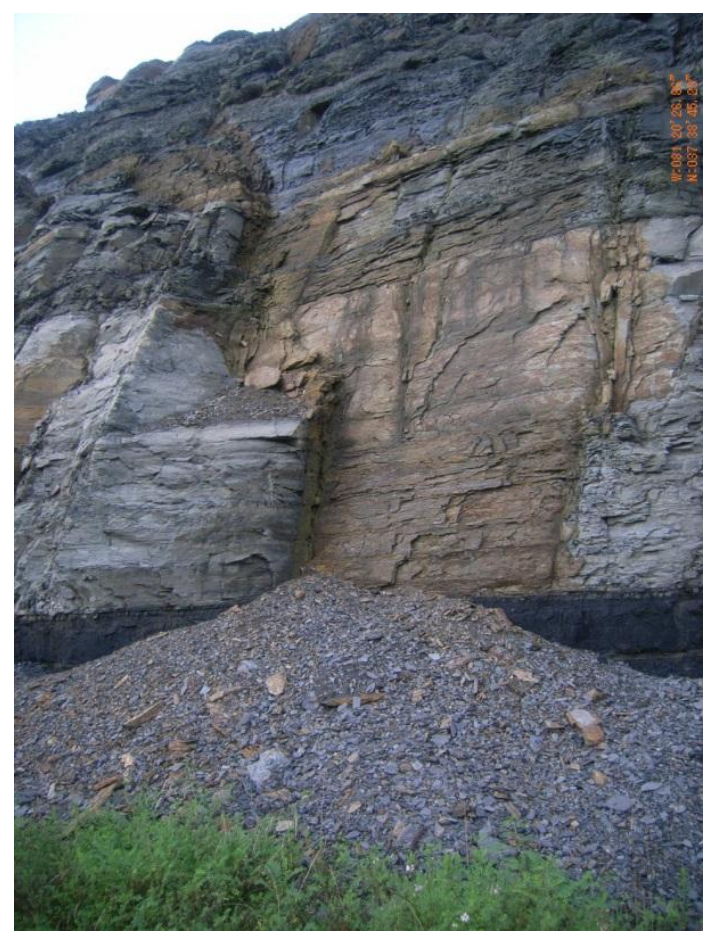

Photo 2: Extensive eroding of siltstone layers on lower benches at Location 2. 


\section{Location 3: US Route 121, Northbound Lane}

County: Raleigh

Coordinates: (37.695577, -81.308923)

RHRS Results for Location 3

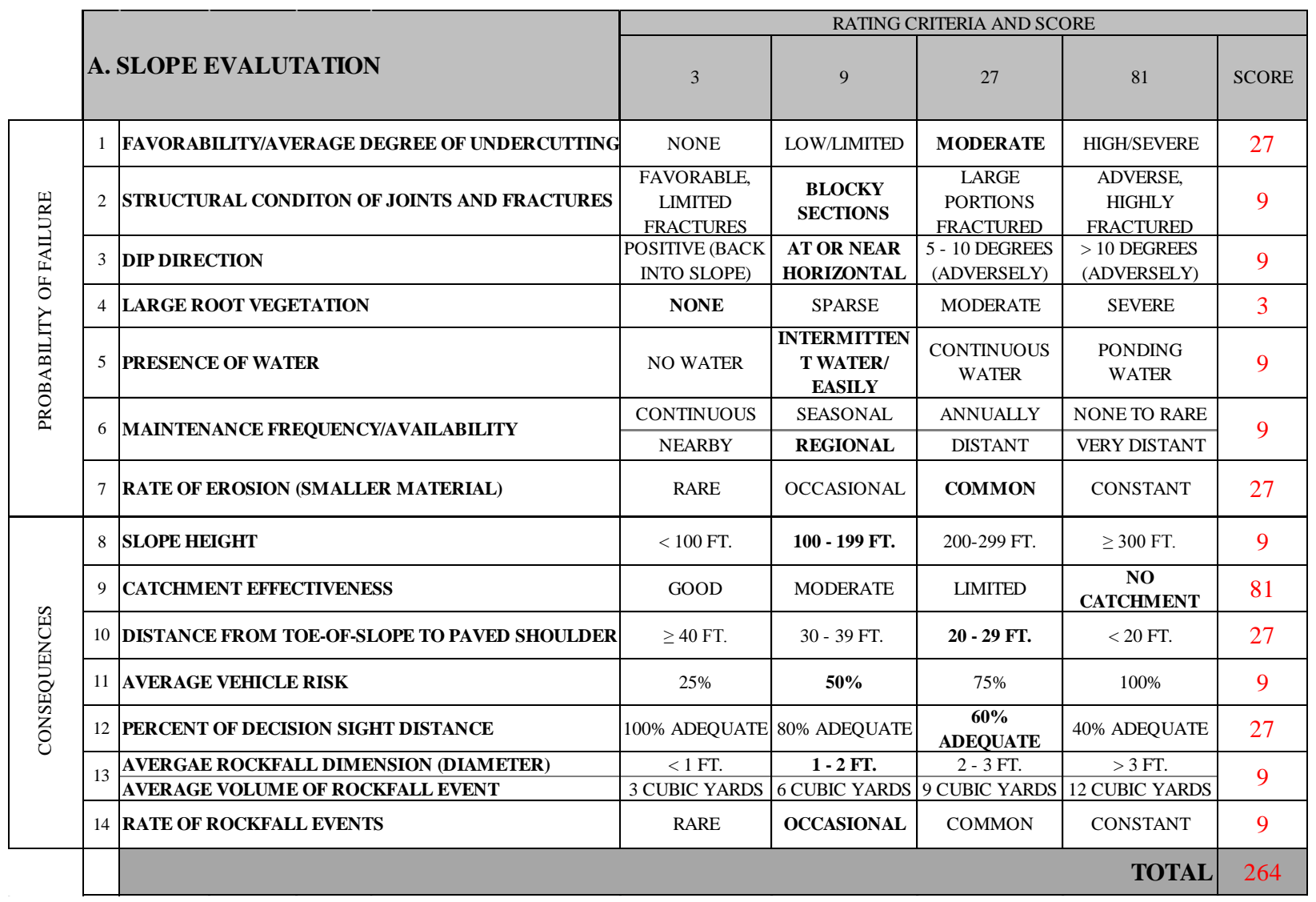

Field Notes Associated with RHRS Scores for Location 3

\begin{tabular}{|c|l|}
\hline Category \# & Note \\
\hline 7 & Large amount of siltstone erosion on upper benches. (See Photo 1) \\
\hline 8 & Total slope height $=$ approximately 180 feet. \\
\hline 9 & No distinguishable catchment area at toe of slope. \\
\hline 10 & Distance $=24$ feet. \\
\hline 11 & Taken from WVDOT website, Average Daily Traffic $=5000$. \\
\hline 13 & $\begin{array}{l}\text { Majority of fallen rocks were small, localized larger blocks from more competent rocks on } \\
\text { upper backslopes. (See Photo 2) }\end{array}$ \\
\hline
\end{tabular}


Photographs:

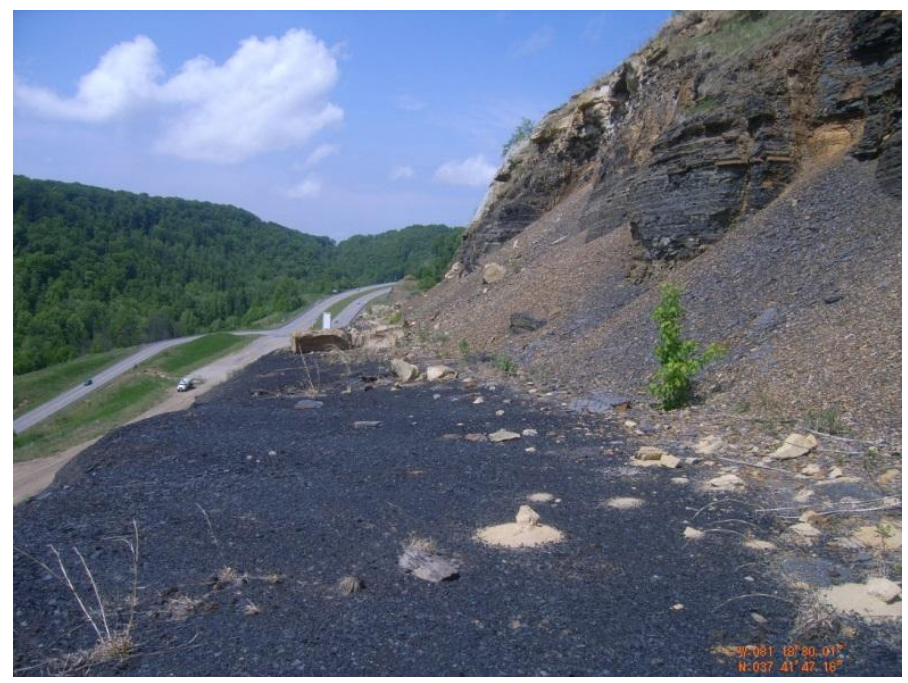

Photo 1: Large amounts of siltstone erosion on benches at Location 3.

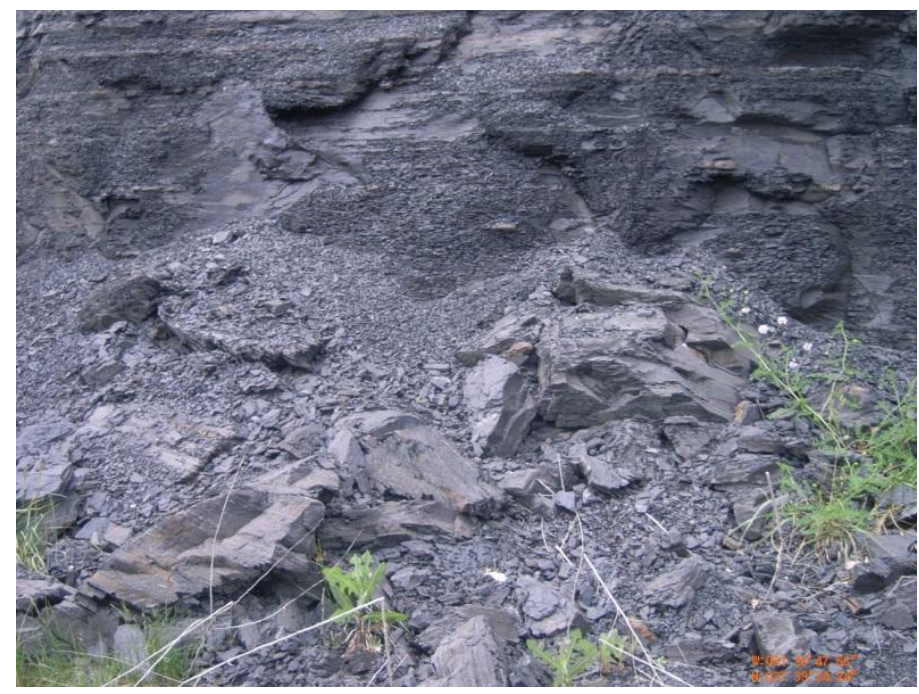

Photo 2: Larger fallen rocks from localized failure on upper bench at Location 3. 


\section{Location 4: US Route 50, on-ramp for Eastbound Lane}

County: Wood

Coordinates: (39.257170, -81.531273)

RHRS Results for Location 4

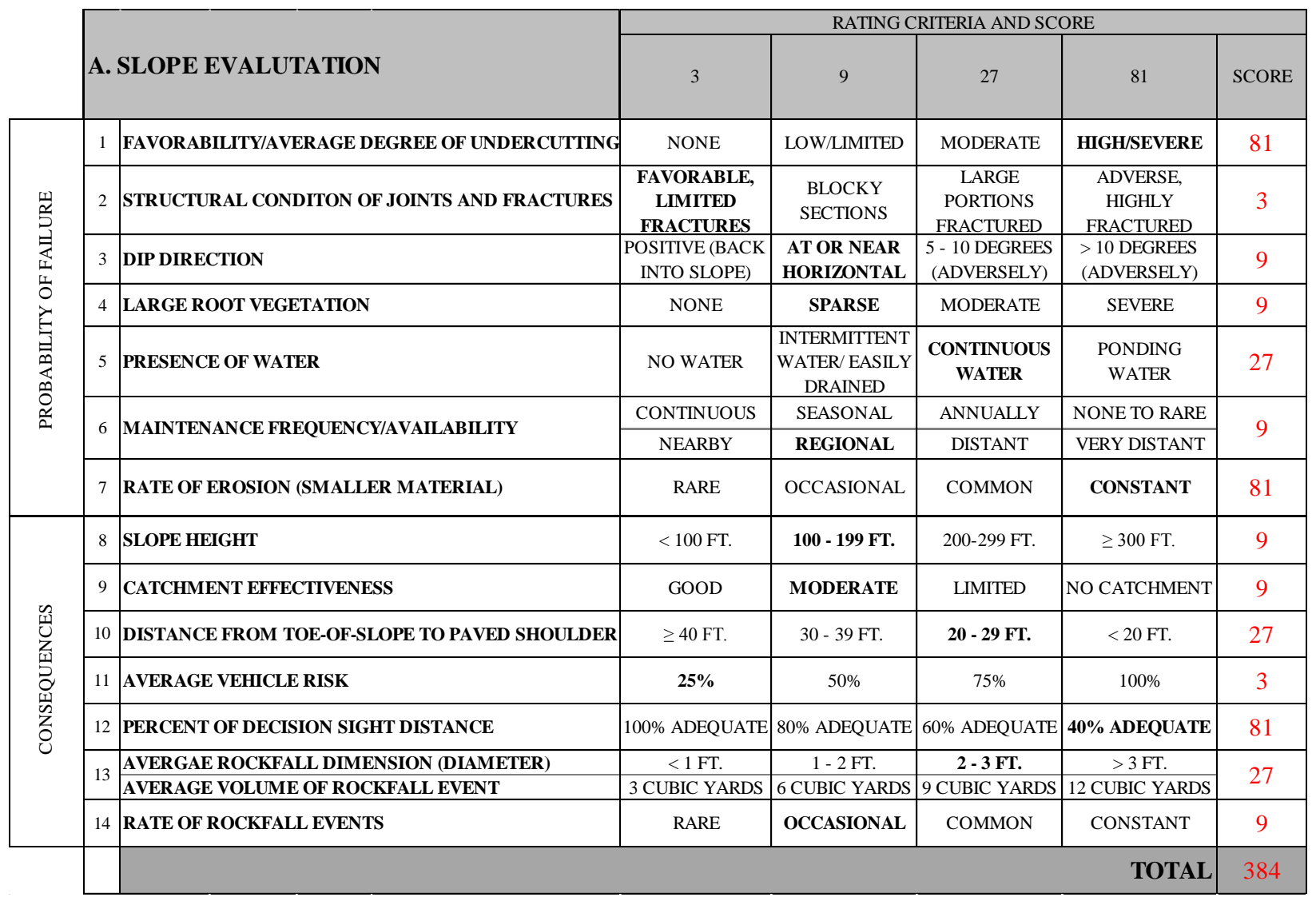

Field Notes Associated with RHRS Scores for Location 4

\begin{tabular}{|c|l|}
\hline Category \# & Note \\
\hline 1 & Noticeably large undercuts from eroding redbed shales in some areas. (See Photo 1) \\
\hline 7 & Large rate of erosion due to Redbed shales. (See Photo 2) \\
\hline 8 & Total slope height $=$ approximately 160 feet. \\
\hline 9 & Ditch's primary function is for drainage, hasn't been tested by rockfall. (See Photo 3). \\
\hline 10 & Distance $=25$ feet. \\
\hline 11 & Taken from WVDOT website, Average Daily Traffic $=500$ (on-ramp). \\
\hline 12 & Estimated minimum Decision Sight Distance $=450$ feet. \\
\hline 13 & Minimum rockfall events, but rocks are typically quite large when they do fall. \\
\hline 14 & Falls only likely after large rains or during first thaw of season. \\
\hline
\end{tabular}


Photographs:

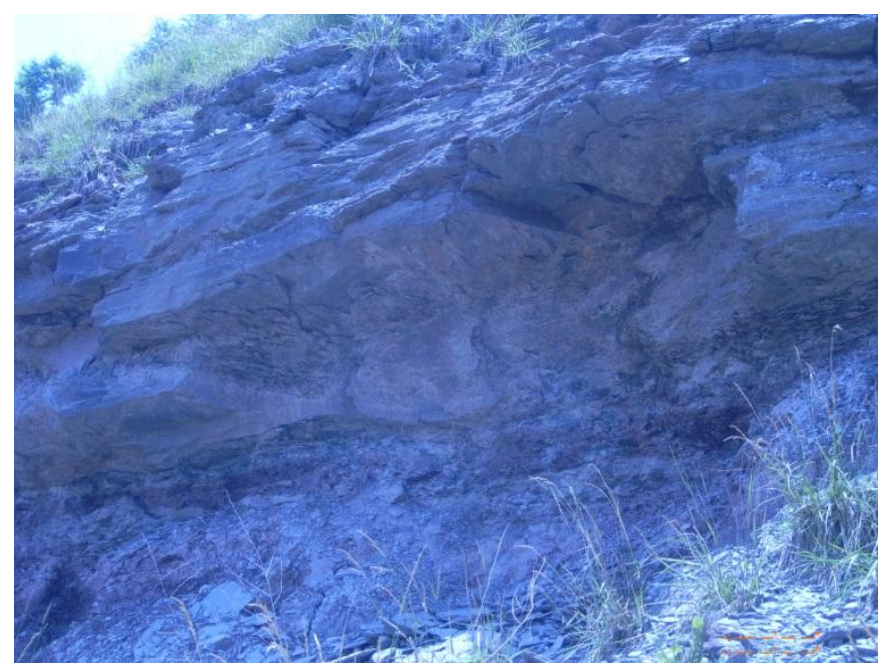

Photo 1: Large undercut from Redbed shale erosion below more competent rock strata at Location 4.

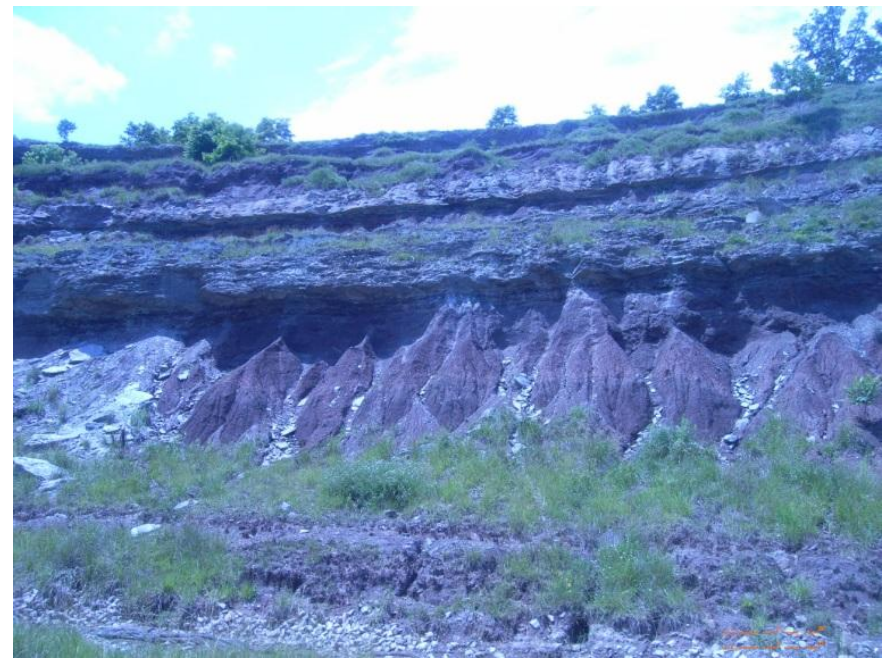

Photo 2: Mounds of erosion from highly friable Redbed shales at Location 4.

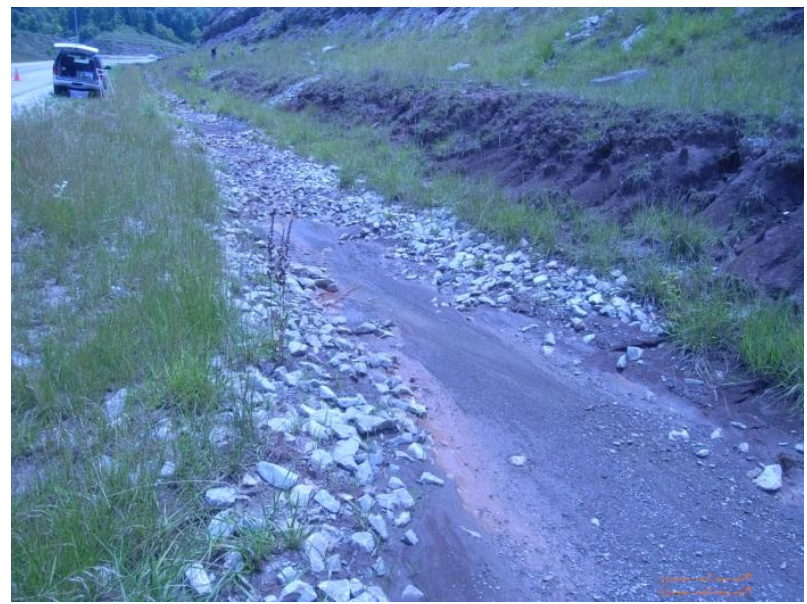

Photo 3: Drainage ditch at toe of slope, filling with eroded material at Location 4. 


\section{Location 5: US Route 35, Southbound Lane}

County: Mason

Coordinates: (38.779380, -82.067514)

RHRS Results for Location 5

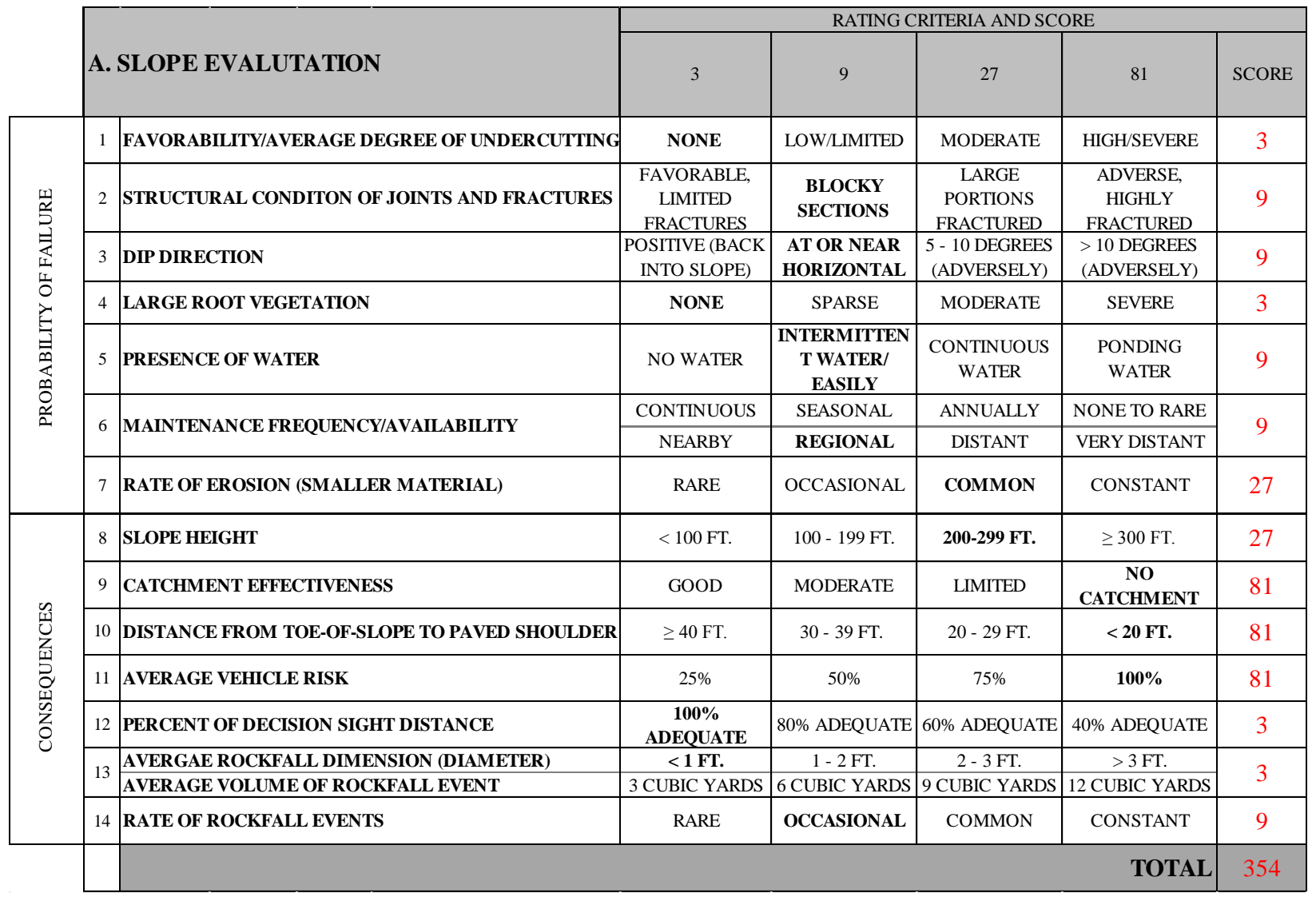

Field Notes Associated with RHRS Scores for Location 5

\begin{tabular}{|c|l|}
\hline Category \# & Note \\
\hline 2 & All but one backslope made up of soft, friable rock; small sample size \\
\hline 7 & $\begin{array}{l}\text { Slope made up highly of Redbed shales, but was well vegetated to reduce erosion (See } \\
\text { Photo 1) }\end{array}$ \\
\hline 8 & Total slope height $=$ approximately 240 feet. \\
\hline 9 & No distinguishable catchment area at toe of slope. \\
\hline 10 & $\begin{array}{l}\text { Distance }=16 \text { feet, which was smallest measured distance of all slopes studied. (See Photo } \\
2)\end{array}$ \\
\hline 11 & Taken from WVDOT website, Average Daily Traffic $=12000$. \\
\hline 14 & Minimal amounts of rockfall on benches. \\
\hline
\end{tabular}


Photographs:

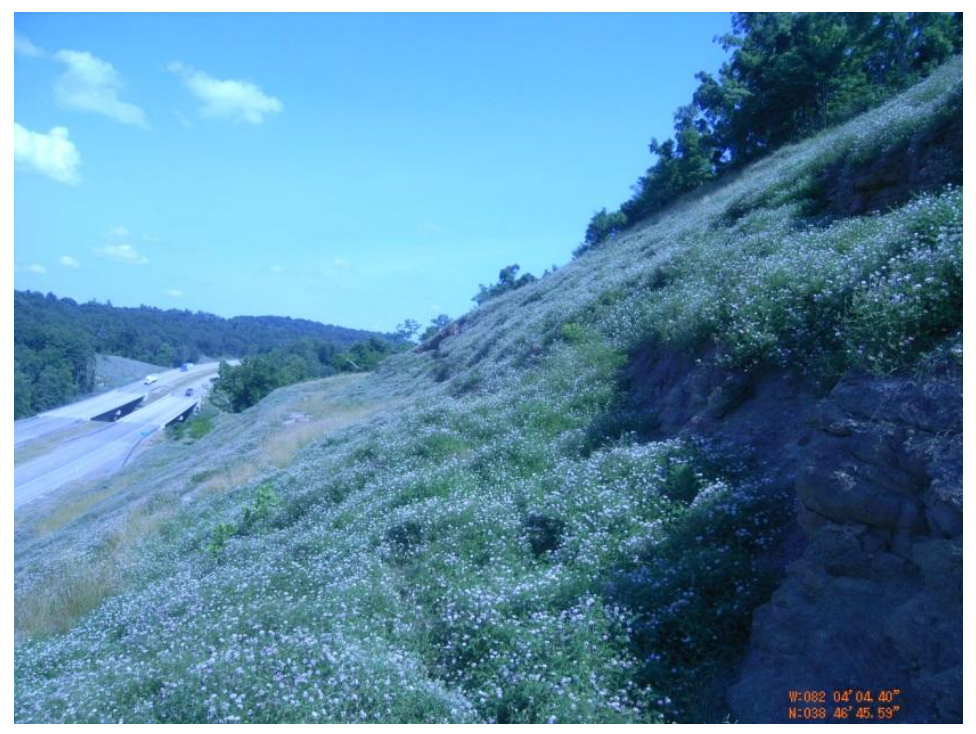

Photo 1: All backslopes and benches highly vegetated.

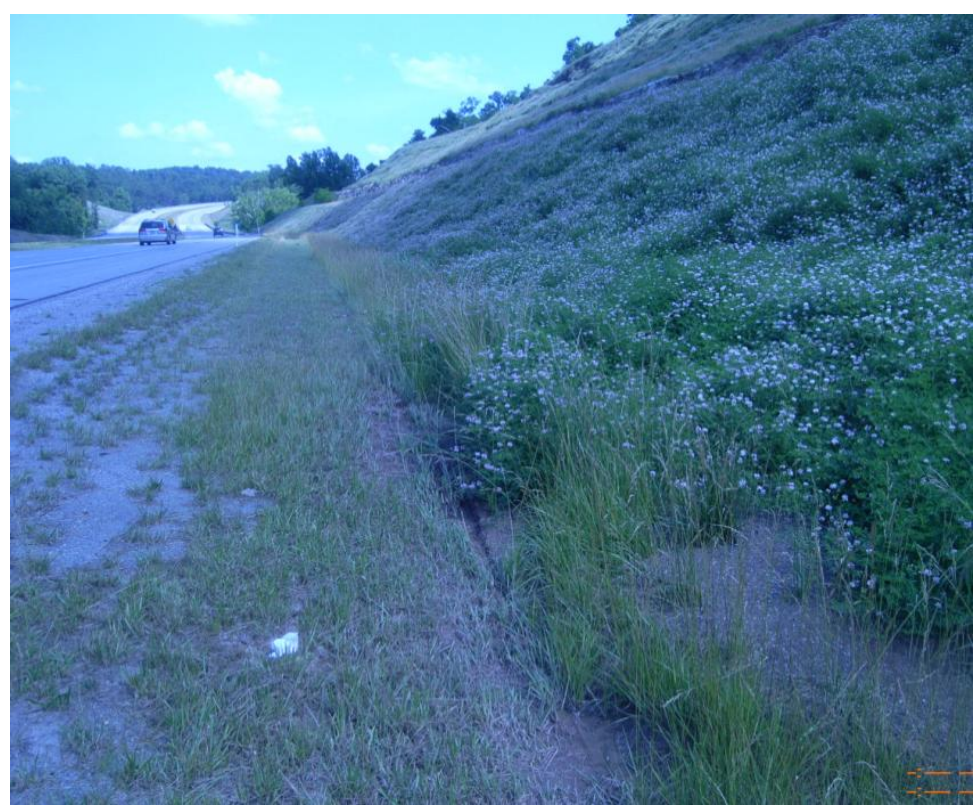

Photo 2: Limited distance between roadway shoulder and toe of slope. 


\section{Location 6: US Route 35 exit ramp (to WV Route 817 N)}

County: Mason

Coordinates: (38.766934, -82.007347)

\section{RHRS Results for Location 6}

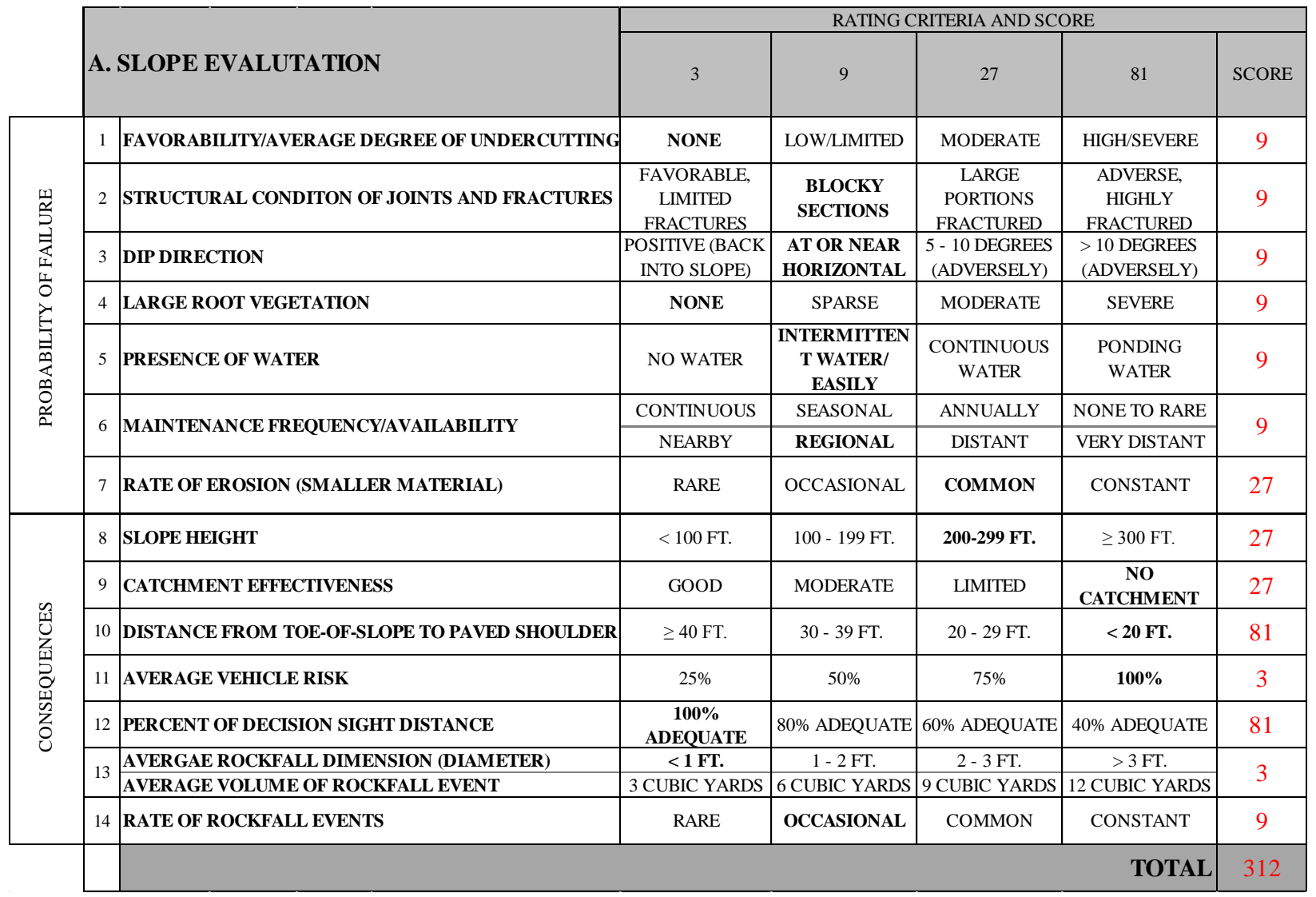

Field Notes Associated with RHRS Scores for Location 6

\begin{tabular}{|c|l|}
\hline Category \# & Note \\
\hline 5 & $\begin{array}{l}\text { Rills and gullies present on slope from excessive erosion; easily drained from slope. (See } \\
\text { Photo 1) }\end{array}$ \\
\hline 8 & Total slope height $=$ approximately 225 feet. \\
\hline 9 & Ditch's primary purpose is for drainage; filling with eroded material. \\
\hline 10 & Distance $=17$ feet. \\
\hline 11 & Taken from WVDOT website, Average Daily Traffic $=12000$. \\
\hline 14 & Overall slope appears very stable, no rockfall events in near future. \\
\hline
\end{tabular}


Photographs:

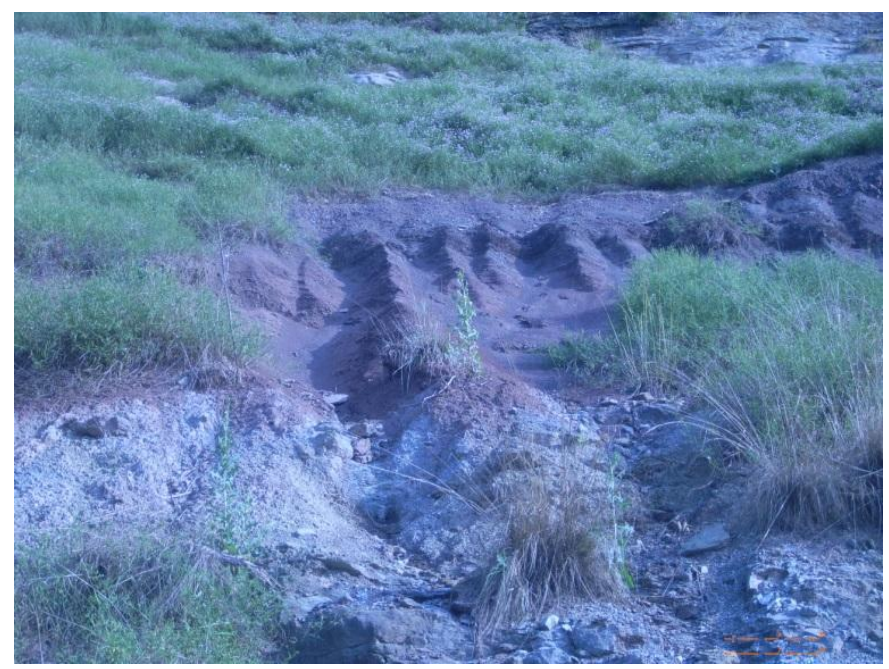

Photo 1: Rills and gullies formed on lower backslopes.

Compilation of the scores from the six sites produced the following GIS map using ArcGIS and the Jenks Classification Method.

Mapped and Ranked RHRS Scores from Locations 1 through 6

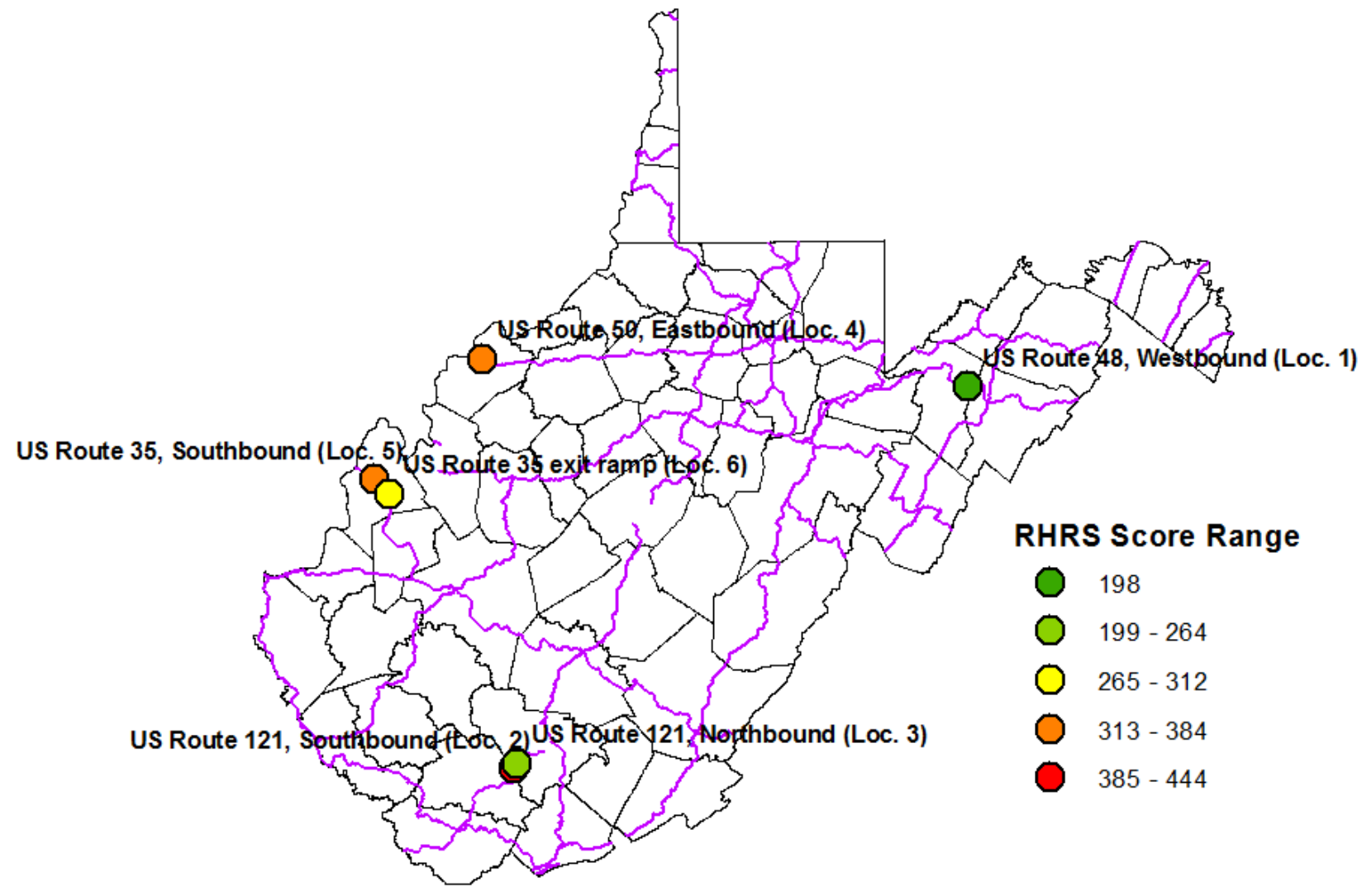




\section{Appendix III: Colorado Rockfall Simulation Program Version 4.0 Field Calibration Workbook}

\section{CRSP Field Calibration Workbook}

\begin{tabular}{|l|l|}
\hline Site Name & \\
\hline City/Town Identification & \\
\hline Highway Identification & \\
\hline Mile Marker / Coordinates (if available) & \\
\hline Construction Plan Stations & \\
\hline Calibration Conducted by & \\
\hline Date & \\
\hline
\end{tabular}

Step 1: Select short section(s) (between 50 to 200 feet long) of the slope to conduct the calibration survey. Observe as many cut slopes in the area as possible, and take descriptive notes on the surface materials that make up each cut slope. Things to take note of include:

- Number of benches on slope

- Overall height of slope

- Percentage of the slope that is hard rock and soft rock

- If there are any sections greater than 50 feet wide that are over $80 \%$ homogenous for the entire height

- Percentage of backslopes on the slope that are homogenous (only one strata or surface type present per backslope).

- Locations of significant rockfall events on slopes

At this point in the calibration investigation, there are three options to choose from based on the available slopes: Methods A, B, and C. Use the following descriptions of the methods to decide on the most feasible method for this study.

\section{Field Calibration Method Descriptions}

1. Method A - Preferred

a. Collect rock fall frequency and dimension data by selecting a sample rock cut slope with at least two benches and back slopes. There must be two material types present on the slope: the top section (or release zone) must be homogenous in one material type, and the bottom section (majority of slope) must be homogenous in the other material type. Rock fall data collection must be done in a manner where frequency and dimension for each rock classification type is collected independently. The 
process of back solving for the hardness of each classification will be iterative with a second slope of exact opposite composition.

b. CRSP calibration: The material classified as hard rock will be given a hardness value that is a maximum for CRSP input parameters. The hardness value of material classified as soft rock will become the only variable calibrated. The process of establishing the hardness value for a rock classification is discussed in the Calibration section of the CRSP write-up.

\section{Method B}

a. Collect rock fall frequency and dimension data by selecting a sample rock cut slope that possess a homogenous rock strata type classified either as hard or soft rock along its vertical back slope heights. The sample calibration section should have a minimum of two back slopes and benches so as the sample calibration has rock fall accumulation on both benches from both back slopes.

b. The sample rock cut slope will be given an initial hardness value range that corresponds to its classification and the process of establishing the calibrated hardness value will be performed. This process is discussed in detail in the Calibration section of the CRSP write-up.

3. Method C

a. Collect rock fall frequency and dimension data by selecting a sample rock cut slope with a minimum of two benches and back slopes. All of the back slopes must exhibit primarily homogenous rock classified as hard rock (high hardness value). This sample rock slope will be selected from a region of Corridor H (WV Route 48).

b. The sample cut slope will be given an initial hardness value that corresponds to its classification and the process of establishing the calibrated hardness value will be performed. This process will be discussed later in detail.

c. After establishing the hardness value for the rock classified as hard rock this value will be held as a constant in the determination of the hardness of material classified as hard material. A second sample site will be used for the calibration of the hardness value of material classified as soft rock. This site selection criterion will only be that of a minimum of two benches and back slopes and may contain any percent composition of material classified as hard or soft material. The most optimal condition being that of 50 percent soft and 50 percent hard material but any substantial amount of material classified as soft rock will suffice for the calibration. Using the calibrated hardness value for hard rock the process of calibrating the soft rock material will be performed. This process will be discussed in the Calibration section of the CRSP write-up. 
Step 2: Fill out the general information on Page 4. The total number of CRSP cells (row 6 in Table 2) will be equal to the sum of the number of backslopes, benches, and the ditch. Look for areas on the slope where it is obvious that large amounts of rocks have fallen from. List those in row 5. Also select the material type that the majority of this section of rock cut is composed of, and is thus the type of material being calibrated in this test. Additional help on material type selection for the 3D program can be found on pages 14 and 15 .

Step 3: Starting at the roadway shoulder, record the information in the table on the following pages (starting with the Geometric Data table on Page 4). Cell numbers increase as you advance up the slope. Reference the tables on Pages 13-15 for the estimated coefficient values and ranges. Use the "rock count" tables to tally rocks of various diameters within each cell (rocks must be greater than 6 inches in diameter to be counted). Remember to stay within the designated section length when conducting the rock count.

Step 4: Calculate the total fallen rocks and average rock radius and shape for the entire section. This can be done in post-processing after field visit if necessary.

Step 5: Repeat with other sections on the slope or neighboring slopes if possible, for accuracy.

Step 6: Compare results with CRSP-2D and 3D results to find calibrated Normal or Hardness Coefficient* values for this slope. Different coefficients, and thus different procedures within the program, must be found for both the 2-Dimensional version and 3Dimensional version of CRSP. While the field data collection for the calibration is the same for both versions, the testing within the programs varies greatly, depending on the calibration procedure used. Please see the additional document: "CRSP Program Calibration Methods" to complete this calibration process. 
Calibration Section \# :

\begin{tabular}{|l|l|}
\hline 1. Location of Section on slope (Station No./Mile Marker) & \\
\hline 2. Section length parallel to roadway & \\
\hline 3. Section height & \\
\hline 4. Total number of benches in section & \\
\hline $\begin{array}{l}\text { 5. Estimated starting location(s) of majority of rockfall events } \\
\text { (Bench \#, height, etc.) }\end{array}$ & \\
\hline 6. Total number of CRSP cells for this section & \\
\hline
\end{tabular}

\section{SELECTED SLOPE MATERIAL TYPE TO BE CALIBRATED (circle one):}

HARD BEDROCK SOFT BEDROCK FIRM SOIL/TALUS OTHER:

Total fallen rocks in section:

Average diameter of fallen rocks in section:

Average fallen rock shape(s) (Circle all that apply) :

Spherical Cylindrical Discoidal Tetrahedral Cubical

Geometric Data For Section

\begin{tabular}{|l|l|l|l|l|}
\hline Cell \# & Description & Width/Height (ft.) & Angle $\left(^{\circ}\right)$ & Notes \\
\hline & & W & & \\
& & H & & \\
\hline & & W & & \\
\hline & & W & & \\
\hline & & W & & \\
\hline & & H & & \\
\hline & & H & & \\
\hline & & W & & \\
\hline & & W & & \\
\hline & & W & & \\
\hline & & H & & \\
\hline & & H & & \\
\hline & & H & & \\
\hline
\end{tabular}

*(additional geometry sheets available in back of packet) 


\begin{tabular}{|c|c|c|c|c|c|c|c|c|}
\hline Cell \# & 1 & 2 & 3 & 4 & 5 & 6 & 7 & 8 \\
\hline $\begin{array}{l}\text { Cell location and type } \\
\text { (Bench, backslope...) }\end{array}$ & Roadway & & & & & & & \\
\hline $\begin{array}{l}\text { Tangential Length } \\
\text { (ft.) and Angle }\end{array}$ & $/ 0^{\circ}$ & / & / & / & / & / & / & / \\
\hline $\begin{array}{l}\text { Estimated Surface } \\
\text { Roughness }\end{array}$ & 0.0 & & & & & & & \\
\hline Vegetative Cover (\%) & $0 \%$ & & & & & & & \\
\hline Material Type & Pavement & & & & & & & \\
\hline $\begin{array}{l}\text { Estimated Tangential } \\
\text { Coefficient }\end{array}$ & & & & & & & & \\
\hline $\begin{array}{c}\text { Estimated Normal } \\
\text { Coefficient RANGE }\end{array}$ & & & & & & & & \\
\hline $\begin{array}{l}\text { Estimated Hardness } \\
\text { Coefficient RANGE }\end{array}$ & & & & & & & & \\
\hline
\end{tabular}

\begin{tabular}{|c|c|c|c|c|c|c|c|c|}
\hline Cell \# & $\mathbf{9}$ & $\mathbf{1 0}$ & $\mathbf{1 1}$ & $\mathbf{1 2}$ & $\mathbf{1 3}$ & $\mathbf{1 4}$ & $\mathbf{1 5}$ & $\mathbf{1 6}$ \\
\hline $\begin{array}{c}\text { Cell location and type } \\
\text { (Bench, backslope...) }\end{array}$ & & & & & & & & \\
\hline $\begin{array}{c}\text { Tangential Length } \\
\text { (ft.) and Angle }\end{array}$ & $/$ & $/$ & $/$ & $/$ & $/$ & $/$ & $/$ & $/$ \\
\hline $\begin{array}{c}\text { Estimated Surface } \\
\text { Roughness }\end{array}$ & & & & & & & & \\
\hline Vegetative Cover (\%) & & & & & & & & \\
\hline $\begin{array}{c}\text { Material Type } \\
\text { Estimated Tangential } \\
\text { Coefficient }\end{array}$ & & & & & & & & \\
\hline $\begin{array}{c}\text { Estimated Normal } \\
\text { Coefficient RANGE }\end{array}$ & & & & & & & & \\
\hline $\begin{array}{c}\text { Estimated Hardness } \\
\text { Coefficent RANGE }\end{array}$ & & & & & & & & \\
\hline
\end{tabular}

*Remember that the tallest portion of the slope (i.e. the uppermost backslope) is Cell 1. 
METHOD A WORKSHEET 2

Section \#:

*Possible Material Types include:

$>$ Hard rock

$>$ Soft rock

$>$ Firm soil

$>$ Other (please specify)

○ Soft soil

- Intermediate soil

- Gravel to cobble talus

- Boulder talus

○ Asphalt

*Remember: Entire slope must be homogenous with except for top cell (release zone)

\begin{tabular}{|c|c|c|c|c|c|c|c|}
\hline \multirow{2}{*}{$\begin{array}{c}\text { Cell \# } \\
\text { (benches } \\
\text { only) }\end{array}$} & \multirow{2}{*}{$\begin{array}{c}\text { Material } \\
\text { Type }\end{array}$} & \multicolumn{6}{|c|}{ Rock Diameter (ft.) } \\
\hline & & $<1$ & $\begin{array}{l}1- \\
1.9\end{array}$ & $\begin{array}{l}2- \\
2.9\end{array}$ & $\begin{array}{l}3- \\
3.9\end{array}$ & $\begin{array}{l}4- \\
4.9\end{array}$ & $\geq 5$ \\
\hline \multicolumn{8}{|l|}{1} \\
\hline \multicolumn{8}{|l|}{2} \\
\hline \multicolumn{8}{|l|}{3} \\
\hline \multicolumn{8}{|l|}{4} \\
\hline \multicolumn{8}{|l|}{5} \\
\hline \multicolumn{8}{|l|}{6} \\
\hline \multicolumn{8}{|l|}{7} \\
\hline \multicolumn{8}{|l|}{8} \\
\hline \multicolumn{8}{|l|}{9} \\
\hline \multicolumn{8}{|l|}{10} \\
\hline \multicolumn{8}{|l|}{11} \\
\hline \multicolumn{8}{|l|}{12} \\
\hline \multicolumn{8}{|l|}{13} \\
\hline \multicolumn{8}{|l|}{14} \\
\hline & & & & & & & \\
\hline
\end{tabular}




\begin{tabular}{|c|c|c|c|c|c|c|}
\hline Cell \# & 1 & 2 & 3 & 4 & 5 & 6 \\
\hline $\begin{array}{l}\text { Cell location and } \\
\text { type (Bench, } \\
\text { backslope, etc.) }\end{array}$ & Roadway & & & & & \\
\hline $\begin{array}{l}\text { Estimated Surface } \\
\text { Roughness }\end{array}$ & 0.0 & & & & & \\
\hline $\begin{array}{l}\text { Vegetative Cover } \\
(\%)\end{array}$ & $0 \%$ & & & & & \\
\hline $\begin{array}{l}\text { Length (ft.) and } \\
\text { Angle }\end{array}$ & $/ 0^{\circ}$ & / & / & / & / & / \\
\hline $\begin{array}{l}\text { Other material type } \\
\text { present? }(\%)\end{array}$ & None $(0 \%)$ & () & () & () & ) & () \\
\hline $\begin{array}{l}\text { Estimated } \\
\text { Tangential } \\
\text { Coefficient }\end{array}$ & & & & & & \\
\hline $\begin{array}{l}\text { Estimated Normal } \\
\text { Coefficient RANGE }\end{array}$ & & & & & & \\
\hline $\begin{array}{l}\text { Estimated Hardness } \\
\text { Coefficient RANGE }\end{array}$ & & & & & & \\
\hline Cell \# & 7 & 8 & 9 & 10 & 11 & 12 \\
\hline $\begin{array}{l}\text { Cell location and } \\
\text { type (Bench, } \\
\text { backslope, etc.) }\end{array}$ & & & & & & \\
\hline $\begin{array}{c}\text { Estimated Surface } \\
\text { Roughness }\end{array}$ & & & & & & \\
\hline $\begin{array}{c}\text { Vegetative Cover } \\
(\%)\end{array}$ & & & & & & \\
\hline $\begin{array}{l}\text { Length (ft.) and } \\
\text { Angle }\end{array}$ & $/ 0^{\circ}$ & / & / & / & / & / \\
\hline $\begin{array}{l}\text { Other material type } \\
\text { present? }(\%)\end{array}$ & None $(0 \%)$ & () & () & () & () & ( ) \\
\hline $\begin{array}{c}\text { Estimated } \\
\text { Tangential } \\
\text { Coefficient } \\
\end{array}$ & & & & & & \\
\hline $\begin{array}{c}\text { Estimated Normal } \\
\text { Coefficient RANGE }\end{array}$ & & & & & & \\
\hline $\begin{array}{l}\text { Estimated Hardness } \\
\text { Coefficient RANGE }\end{array}$ & & & & & & \\
\hline
\end{tabular}

\begin{tabular}{|c|c|c|c|c|c|c|}
\hline \multirow{2}{*}{ Cell \# } & \multicolumn{6}{|c|}{ Rock Diameter (ft.) } \\
\hline & $<1$ & $\begin{array}{c}1- \\
1.9\end{array}$ & $\begin{array}{c}2- \\
2.9\end{array}$ & 3.9 & $4-9$ & $\geq 5$ \\
\hline $\mathbf{1}$ & & & & & & \\
\hline $\mathbf{2}$ & & & & & & \\
\hline $\mathbf{3}$ & & & & & & \\
\hline $\mathbf{4}$ & & & & & & \\
\hline $\mathbf{5}$ & & & & & & \\
\hline $\mathbf{6}$ & & & & & & \\
\hline 7 & & & & & & \\
\hline $\mathbf{8}$ & & & & & & \\
\hline $\mathbf{9}$ & & & & & & \\
\hline $\mathbf{1 0}$ & & & & & & \\
\hline $\mathbf{1 1}$ & & & & & & \\
\hline $\mathbf{1 2}$ & & & & & & \\
\hline
\end{tabular}




\begin{tabular}{|c|l|l|l|l|l|l|l|l|l|l|l|}
\hline Cell \# & $\mathbf{l}$ & $\mathbf{2}$ & $\mathbf{3}$ & $\mathbf{4}$ & $\mathbf{5}$ & $\mathbf{6}$ & $\mathbf{7}$ & $\mathbf{8}$ & $\mathbf{9}$ & $\mathbf{1 0}$ & $\mathbf{1 1}$ \\
\hline $\begin{array}{c}\text { Cell location and type } \\
\text { (Bench, backslope) }\end{array}$ & & & & & & & & & & \\
\hline $\begin{array}{c}\text { Estimated Surface } \\
\text { Roughness }\end{array}$ & & & & & & & & & & \\
\hline \begin{tabular}{c} 
Vegetative Cover (\%) \\
\hline $\begin{array}{c}\text { Material Type in Cell } \\
\text { (Must be 100\% } \\
\text { homogenous) }\end{array}$
\end{tabular} & & & & & & & & & & & \\
\hline $\begin{array}{c}\text { Estimated Tangential } \\
\text { Coefficient }\end{array}$ & & & & & & & & & & & \\
\hline $\begin{array}{c}\text { Estimated Normal } \\
\text { Coefficient RANGE }\end{array}$ & & & & & & & & & & & \\
\hline
\end{tabular}

\begin{tabular}{|c|c|c|c|c|c|c|c|c|c|c|c|}
\hline Cell \# & 12 & 13 & 14 & 15 & 16 & 17 & 18 & 19 & 20 & 21 & 22 \\
\hline $\begin{array}{l}\text { Cell location and type } \\
\text { (Bench, backslope) }\end{array}$ & & & & & & & & & & & \\
\hline $\begin{array}{c}\text { Estimated Surface } \\
\text { Roughness }\end{array}$ & & & & & & & & & & & \\
\hline Vegetative Cover (\%) & & & & & & & & & & & \\
\hline $\begin{array}{l}\text { Material Type in Cell } \\
\text { (must be } 100 \% \\
\text { homogenous) }\end{array}$ & & & & & & & & & & & \\
\hline $\begin{array}{c}\text { Estimated Tangential } \\
\text { Coefficient }\end{array}$ & & & & & & & & & & & \\
\hline $\begin{array}{c}\text { Estimated Normal } \\
\text { Coefficient RANGE }\end{array}$ & & & & & & & & & & & \\
\hline
\end{tabular}


METHOD C WORKSHEET 2

Section \# :

*Possible Material Types include:

Hard rock

$>$ Soft rock

Firm soil

$>$ Other (please specify)

- Soft soil

○ Intermediate soil

- Gravel to cobble talus

- Boulder talus

- Asphalt

\begin{tabular}{|c|c|c|c|c|c|c|c|}
\hline \multirow{2}{*}{$\begin{array}{c}\text { Cell \# } \\
\text { (benches } \\
\text { only) }\end{array}$} & \multirow{2}{*}{$\begin{array}{c}\text { Material } \\
\text { Type }\end{array}$} & \multicolumn{6}{|c|}{ Rock Diameter (ft.) } \\
\hline & & $<1$ & $\begin{array}{l}1- \\
1.9\end{array}$ & $\begin{array}{c}2- \\
2.9\end{array}$ & $\begin{array}{c}3- \\
3.9\end{array}$ & $\begin{array}{r}4- \\
4.9\end{array}$ & $\geq 5$ \\
\hline \multicolumn{8}{|l|}{1} \\
\hline \multirow{2}{*}{\multicolumn{8}{|c|}{2}} \\
\hline & & & & & & & \\
\hline \multirow{2}{*}{\multicolumn{8}{|c|}{3}} \\
\hline & & & & & & & \\
\hline \multirow{2}{*}{\multicolumn{8}{|c|}{4}} \\
\hline & & & & & & & \\
\hline \multirow{2}{*}{\multicolumn{8}{|c|}{5}} \\
\hline & & & & & & & \\
\hline \multirow{2}{*}{\multicolumn{8}{|c|}{6}} \\
\hline & & & & & & & \\
\hline \multicolumn{8}{|l|}{7} \\
\hline & & & & & & & \\
\hline \multicolumn{8}{|l|}{8} \\
\hline \multirow{2}{*}{\multicolumn{8}{|c|}{9}} \\
\hline & & & & & & & \\
\hline \multicolumn{8}{|l|}{10} \\
\hline & & & & & & & \\
\hline \multicolumn{8}{|l|}{11} \\
\hline & & & & & & & \\
\hline \multicolumn{8}{|l|}{12} \\
\hline & & & & & & & \\
\hline \multicolumn{8}{|l|}{13} \\
\hline & & & & & & & \\
\hline
\end{tabular}




\section{CRSP 2-Dimensional Supplemental Data}

*All of the following information was taken from CRSP Version 4.0 User's Manual (Jones, 2000).

Table 1: General Tangential Coefficient Ranges for Different Slope Surface Types

\begin{tabular}{|l|l|l|}
\hline Description of Slope & Tangential Coefficient $\left(\mathrm{R}_{\mathrm{t}}\right)$ & Remarks \\
\hline Smooth hard surfaces and paving & $0.90-1.0$ & -Use lower $\mathrm{R}_{\mathrm{t}}$ as density of \\
vegetation on the slope increases.
\end{tabular}

Table 2: General Normal Coefficient Ranges for Different Slope Surface Types

\begin{tabular}{|c|c|c|}
\hline Description of Slope & Normal Coefficient $\left(\mathrm{R}_{\mathrm{n}}\right)$ & Remarks \\
\hline Smooth hard surfaces and paving & $0.60-1.0$ & \multirow{4}{*}{$\begin{array}{l}\text {-If max. velocity is desired } \\
\text { output, use lower values in range } \\
\text { If average velocity is desired } \\
\text { output, use higher values in } \\
\text { range. }\end{array}$} \\
\hline Most bedrock and boulder fields & $0.15-0.30$ & \\
\hline Talus and firm soil slopes & $0.12-0.20$ & \\
\hline Soft soil slopes & $0.10-0.20$ & \\
\hline
\end{tabular}

Surface roughness is a function of the size of the rock and the irregularity of the surface. Stretch a measuring tape down the backslope (within a given cell on CRSP) and measure the largest distance to the actual slope perpendicular to the tape. Divide this distance by the average falling rock radius to achieve a value for $S$. Values should typically be less than 2.0, with pavement being between 0.1 and 0.5 (see 3D section for additional recommendations on surface roughness values).

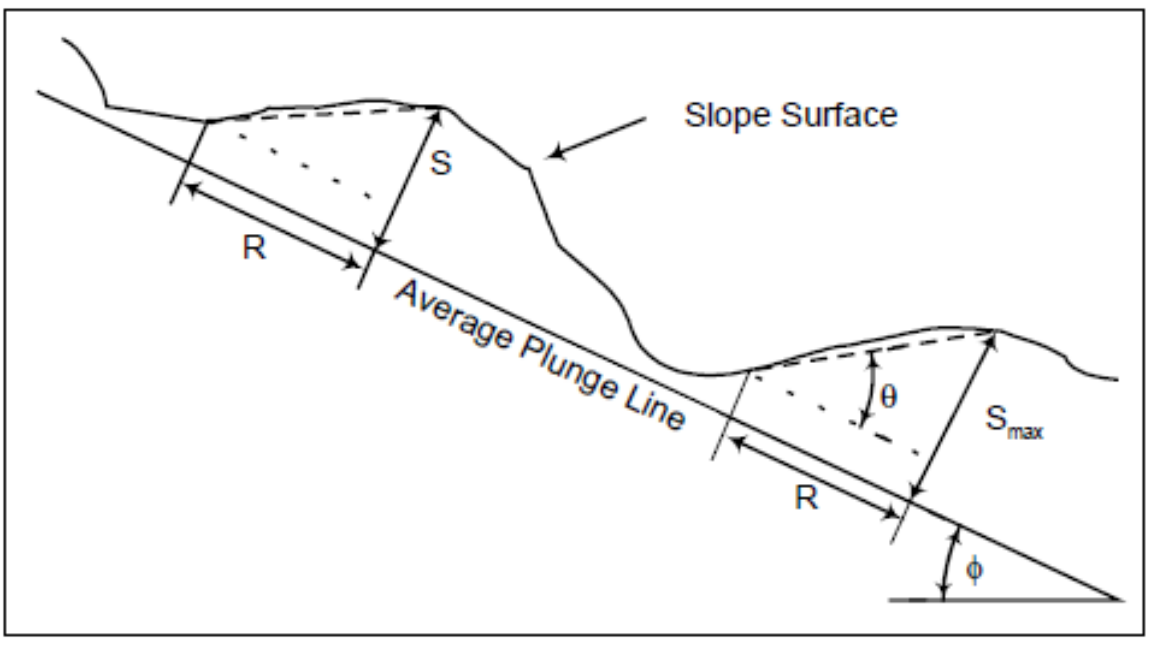

Figure 1: Visual Description of the Surface Roughness input in CRSP-2D 


\section{CRSP 3-Dimensional Supplemental Data}

*All of the following information was taken from CRSP-3D User's Manual (Andrews, 2012).

Table 3: General Roughness Input Ranges and Descriptions for Slopes

\begin{tabular}{|l|l|}
\hline Roughness Value Range & Comments \\
\hline$>3.0$ & $\begin{array}{l}\text { Generally only used for very rough slope surfaces } \\
\text { where high bounce heights are predicted or have } \\
\text { been observed. }\end{array}$ \\
\hline $1.0-2.0$ & $\begin{array}{l}\text { Generally for use on most slope surfaces with most } \\
\text { falling rock geometries, even if the slope is } \\
\text { relatively smooth. This compensates for the non- } \\
\text { uniformity in most rock shapes and slope surfaces. }\end{array}$ \\
\hline $0.1-1.0$ & $\begin{array}{l}\text { Use judiciously*. Roughness values below 2.0 } \\
\text { may produce higher than expected values when } \\
\text { modeling spherical rocks. }\end{array}$ \\
\hline
\end{tabular}

* NOTE: CRSP was developed primarily for use with "natural" slopes in Colorado where construction equipment has not been used to smooth rock cut surfaces. Thus, the user's manual's recommendation to avoid Roughness values lower than 1.0 should be ignored when calibrating CRSP for West Virginia rock cut slopes. This table is given just for a general guide, and the actual process of developing accurate roughness values can be found in the 2-D section on Page 13.

Table 4: General Hardness Coefficient Ranges for Different Slope Surface Types

\begin{tabular}{|l|l|l|l|}
\hline Slope Material Type & Material Description & Hardness Range & Hardness Measure \\
\hline Soft & Soft clay / Loose sand & $0.1-0.3$ & $\begin{array}{l}\text { Footprints left in soil } \\
\text { (*Photo 1) }\end{array}$ \\
\hline Intermediate & Medium clay & $0.3-0.5$ & $\begin{array}{l}75 \% \text { - 100\% rock pick } \\
\text { penetration (*Photo 2) }\end{array}$ \\
\hline Firm & Hard clay / Soft bedrock & $0.4-0.7$ & $\begin{array}{l}50 \%-75 \% \text { rock pick } \\
\text { penetration (*Photo 3) }\end{array}$ \\
\hline Gravel to Cobble Talus & Gravel / Cobbles & $0.2-0.6$ & $\begin{array}{l}\text { Rock debris (talus) covers > } \\
\text { 40\% of slope. (*Photo 4) }\end{array}$ \\
\hline Boulder Talus & Boulder field & $0.5-0.8$ & $\begin{array}{l}\text { Rock debris covers > 40\% } \\
\text { of slope. (*Photo 5) }\end{array}$ \\
\hline Hard Bedrock & Fresh hard rock & $0.7-0.9$ & $\begin{array}{l}\text { Rock is intact on slope. } \\
\text { Concrete. (*Photo 6) }\end{array}$ \\
\hline
\end{tabular}

*Accompanying Photographs for visual estimation of Hardness Coefficient on the next page. 

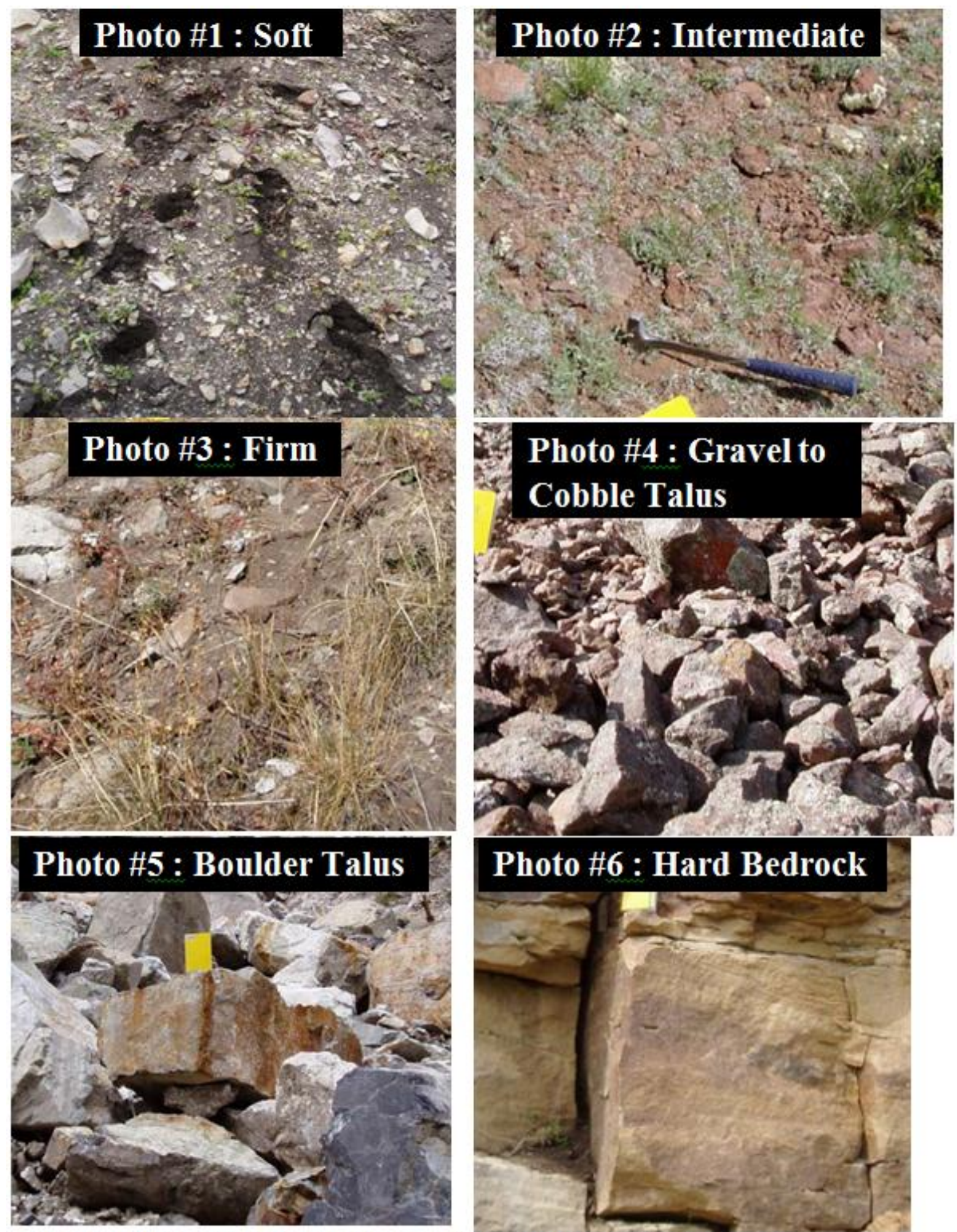

Figure 1: Photographic ex am ples of surface $m$ aterial types available in CRSP (Andrews 2012) 


\section{Appendix IV: Additional CRSP-2D Field Calibration Models}

General Information collected from Soft Bedrock CRSP-2D Calibration Site 2

\begin{tabular}{|l|c|}
\hline 1. Location of Section on Slope: & Box Cut \#2, left side of highway \\
\hline 2. Section Length Parallel to Roadway: & 200 feet \\
\hline 3. Vertical Section Height: & 25 feet \\
\hline 4. Total Number of Benches: & Uppermost part of Backslope 2 (Cell \# 8) \\
\hline $\begin{array}{l}\text { 5. Estimated Starting Location of Most } \\
\text { Rockfall Events: }\end{array}$ & 8 \\
\hline $\begin{array}{l}\text { 6. Total number of CRSP “cells" needed } \\
\text { for this section: }\end{array}$ & \multicolumn{1}{|c|}{135} \\
\hline $\begin{array}{l}\text { 7. Total counted fallen rocks in section: } \\
\text { 8. Average diameter of fallen rocks in } \\
\text { section: }\end{array}$ & 1.30 feet \\
\hline
\end{tabular}

Completed Cell Identification Table for Soft Bedrock Calibration Site 2

\begin{tabular}{|c|c|c|c|c|c|c|c|c|}
\hline Cell \# & $\mathbf{8}$ & $\mathbf{7}$ & $\mathbf{6}$ & $\mathbf{5}$ & $\mathbf{4}$ & $\mathbf{3}$ & $\mathbf{2}$ & $\mathbf{1}$ \\
\hline Cell Location & Road & $\begin{array}{c}\text { Shoulder/ } \\
\text { Ditch }\end{array}$ & $\begin{array}{c}\text { Backslope } \\
1\end{array}$ & Bench 1 & $\begin{array}{c}\text { Backslope } \\
2\end{array}$ & Bench 2 & $\begin{array}{c}\text { Backslope } \\
3.1\end{array}$ & $\begin{array}{c}\text { Backslope } \\
3.2\end{array}$ \\
\hline $\begin{array}{c}\text { Height/ } \\
\text { Width (ft.) }\end{array}$ & n/a & 33 & 14 & 20 & 34 & 25 & 26 & 20 \\
\hline $\begin{array}{c}\text { Angle } \\
\text { (Backslope } \\
\text { only) }\end{array}$ & - & - & $35^{\circ}$ & - & $70^{\circ}$ & - & $70^{\circ}$ & $70^{\circ}$ \\
\hline $\begin{array}{c}\text { Estimated } \\
\text { Surface } \\
\text { Roughness }\end{array}$ & 0.0 & 0.1 & 0.2 & 0.0 & 0.8 & 0.0 & 0.5 & 1.2 \\
\hline $\begin{array}{c}\text { Vegetative } \\
\text { Cover (\%) }\end{array}$ & 0 & $60 \%$ & $5 \%$ & $10 \%$ & $3 \%$ & $20 \%$ & $20 \%$ & $40 \%$ \\
\hline $\begin{array}{c}\text { Material } \\
\text { Type in Cell }\end{array}$ & Asphalt & Firm soil & $\begin{array}{c}\text { Talus/ } \\
\text { Firm soil }\end{array}$ & $\begin{array}{c}\text { Soft } \\
\text { bedrock }\end{array}$ & $\begin{array}{c}\text { Soft } \\
\text { bedrock }\end{array}$ & $\begin{array}{c}\text { Soft } \\
\text { bedrock }\end{array}$ & $\begin{array}{c}\text { Soft } \\
\text { bedrock }\end{array}$ & $\begin{array}{c}\text { Hard } \\
\text { bedrock }\end{array}$ \\
\hline $\begin{array}{c}\text { Initial CRSP } \\
\text { R Range }\end{array}$ & $0.6-$ & $0.12-$ & $\begin{array}{c}0.12- \\
0.20\end{array}$ & $\begin{array}{c}0.15- \\
0.30\end{array}$ & $\begin{array}{c}0.15- \\
0.30\end{array}$ & $\begin{array}{c}0.15- \\
0.30\end{array}$ & $\begin{array}{c}0.15- \\
0.30\end{array}$ & $\begin{array}{c}0.20- \\
0.60\end{array}$ \\
\hline
\end{tabular}


Completed Rockfall Tally Table for Soft Bedrock Calibration Site 2

\begin{tabular}{|c|c|c|c|c|c|c|}
\hline \multirow{2}{*}{ Cell \# } & \multicolumn{6}{|c|}{ Rock Diameter (ft.) } \\
\cline { 2 - 7 } & $\mathbf{< 1 . 0}$ & $\mathbf{1 . 0}-\mathbf{1 . 9}$ & $\mathbf{2 . 0}-\mathbf{2 . 9}$ & $\mathbf{3 . 0}-\mathbf{3 . 9}$ & $\mathbf{4 . 0}-\mathbf{4 . 9}$ & $>\mathbf{5 . 0}$ \\
\hline $\mathbf{8}$ & 0 & 0 & 0 & 0 & 0 & 0 \\
\hline $\mathbf{7}$ & 0 & 0 & 0 & 0 & 0 & 0 \\
\hline $\mathbf{5}$ & 2 & 1 & 0 & 0 & 0 & 0 \\
\hline $\mathbf{3}$ & 36 & 26 & 5 & 1 & 0 & 0 \\
\hline Totals: & $\mathbf{3 8}$ & $\mathbf{2 7}$ & $\mathbf{5}$ & $\mathbf{1}$ & $\mathbf{0}$ & $\mathbf{0}$ \\
\hline
\end{tabular}

Soft Bedrock Calibration Site 2 Slope Profile created in CRSP-2D

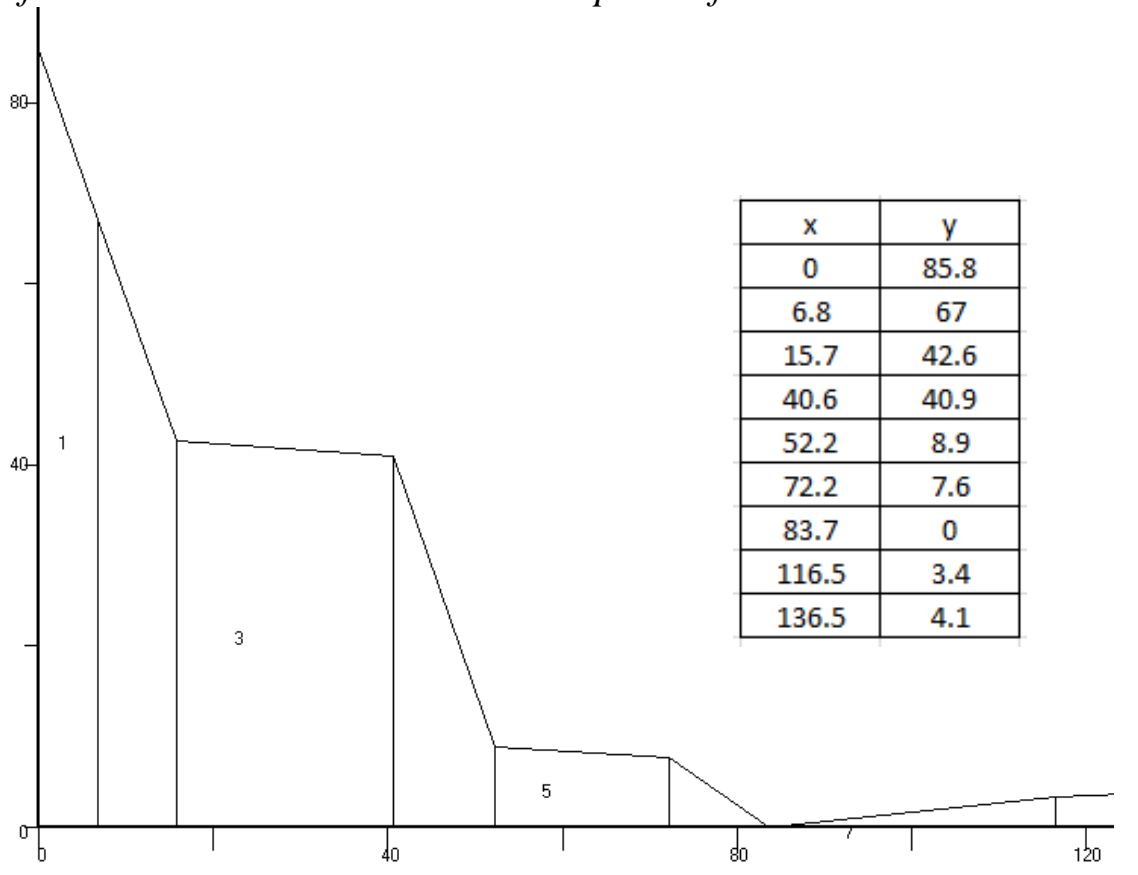


Trial-and-Error CRSP-2D Calibration for Soft Bedrock Calibration Site 2

\begin{tabular}{|c|c|c|c|c|c|c|c|}
\hline \multirow{2}{*}{$\begin{array}{c}\text { Calibration } \\
\text { Run \# }\end{array}$} & \multicolumn{2}{|c|}{$\begin{array}{c}\text { Soft Bedrock } \\
\text { Parameters }\end{array}$} & $\begin{array}{c}\text { Rockfall } \\
\text { Diameter } \\
\text { (ft.) }\end{array}$ & \multirow{2}{*}{$\begin{array}{c}\text { Rockfall } \\
\text { Shape }\end{array}$} & \multicolumn{3}{|c|}{ Rock Accumulation Tally } \\
\cline { 6 - 8 } & $\mathbf{R}_{\mathbf{n}}$ & $\mathbf{R}_{\mathbf{t}}$ & & & $\begin{array}{c}\text { Bench } \\
\mathbf{2}\end{array}$ & $\begin{array}{c}\text { Bench } \\
\mathbf{1}\end{array}$ & Ditch/Road \\
\hline Field & - & - & $<1.0$ & - & 36 & 2 & 0 \\
\hline $\mathbf{1}$ & 0.25 & 0.92 & 0.90 & cylindrical & 32 & 2 & 4 \\
\hline $\mathbf{2}$ & 0.25 & 0.92 & 0.90 & discoidal & 30 & 2 & 6 \\
\hline $\mathbf{3}$ & 0.27 & 0.91 & 0.90 & cylindrical & 37 & 0 & 1 \\
\hline $\mathbf{4}$ & 0.27 & 0.91 & 0.90 & discoidal & 35 & 1 & 2 \\
\hline Field & - & - & $1.0-1.9$ & - & 26 & 1 & 0 \\
\hline $\mathbf{5}$ & 0.25 & 0.92 & 1.30 & cylindrical & 25 & 1 & 1 \\
\hline $\mathbf{6}$ & 0.27 & 0.91 & 1.30 & cylindrical & 26 & 0 & 1 \\
\hline
\end{tabular}


General Information collected from Hard Bedrock CRSP-2D Calibration Site 2

\begin{tabular}{|l|c|}
\hline 1. Location of Section on Slope: & Opposite lane of truck pull-off (northbound) \\
\hline 2. Section Length Parallel to Roadway: & 120 feet \\
\hline 3. Vertical Section Height: & 2 \\
\hline 4. Total Number of Benches: & Both backslopes in mostly localized events \\
\hline $\begin{array}{l}\text { 5. Estimated Starting Location of Most } \\
\text { Rockfall Events: }\end{array}$ & \multicolumn{2}{|c|}{3} \\
\hline $\begin{array}{l}\text { 6. Total number of CRSP “cells" needed } \\
\text { for this section: }\end{array}$ & 312 \\
\hline $\begin{array}{l}\text { 7. Total counted fallen rocks in section: } \\
\text { 8. Average diameter of fallen rocks in } \\
\text { section: }\end{array}$ & 1.10 feet \\
\hline
\end{tabular}

Completed Cell Identification Table for Hard Bedrock Calibration Site 2

\begin{tabular}{|c|c|c|c|c|c|c|c|}
\hline Cell \# & $\mathbf{7}$ & $\mathbf{6}$ & $\mathbf{5}$ & $\mathbf{4}$ & $\mathbf{3}$ & $\mathbf{2}$ & $\mathbf{1}$ \\
\hline Cell Location & Road & $\begin{array}{c}\text { Shoulder/ } \\
\text { Ditch }\end{array}$ & $\begin{array}{c}\text { Backslope } \\
1\end{array}$ & Bench 1 & $\begin{array}{c}\text { Backslope } \\
2\end{array}$ & Bench 2 & $\begin{array}{c}\text { Backslope } \\
3\end{array}$ \\
\hline $\begin{array}{c}\text { Height/ } \\
\text { Width (ft.) }\end{array}$ & $\mathrm{n} / \mathrm{a}$ & 21 & 10 & 23 & 62 & 20 & 50 \\
\hline $\begin{array}{c}\text { Angle } \\
\text { (Backslope } \\
\text { only) }\end{array}$ & - & $-5^{\circ}$ & $46^{\circ}$ & - & $80^{\circ}$ & - & $75^{\circ}$ \\
\hline $\begin{array}{c}\text { Estimated } \\
\text { Surface } \\
\text { Roughness }\end{array}$ & 0.0 & 0.1 & 0.2 & 0.0 & 0.4 & 0.0 & 0.75 \\
\hline $\begin{array}{c}\text { Vegetative } \\
\text { Cover (\%) }\end{array}$ & 0 & $100 \%$ & $100 \%$ & $100 \%$ & $0 \%$ & $80 \%$ & $10 \%$ \\
\hline $\begin{array}{c}\text { Material } \\
\text { Type in Cell }\end{array}$ & Asphalt & Firm soil & Rock talus & $\begin{array}{c}\text { Hard } \\
\text { bedrock }\end{array}$ & $\begin{array}{c}\text { Hard } \\
\text { bedrock }\end{array}$ & $\begin{array}{c}\text { Hard } \\
\text { bedrock }\end{array}$ & $\begin{array}{c}\text { Hard } \\
\text { bedrock }\end{array}$ \\
\hline $\begin{array}{c}\text { Initial CRSP } \\
\text { R Range }\end{array}$ & $0.6-$ & $0.12-$ & $0.12-$ & $0.20-$ & $\begin{array}{c}0.20- \\
0.60\end{array}$ & $\begin{array}{c}0.20- \\
0.60\end{array}$ & $\begin{array}{c}0.20- \\
0.60\end{array}$ \\
\hline
\end{tabular}


Completed Rockfall Tally Table for Hard Bedrock Calibration Site 2

\begin{tabular}{|c|c|c|c|c|c|c|}
\hline \multirow{2}{*}{ Cell \# } & \multicolumn{7}{|c|}{ Rock Diameter (ft.) } \\
\cline { 2 - 7 } & $<\mathbf{1 . 0}$ & $\mathbf{1 . 0}-\mathbf{1 . 9}$ & $\mathbf{2 . 0}-\mathbf{2 . 9}$ & $\mathbf{3 . 0}-\mathbf{3 . 9}$ & $\mathbf{4 . 0}-\mathbf{4 . 9}$ & $>\mathbf{5 . 0}$ \\
\hline $\mathbf{7}$ & 0 & 0 & 0 & 0 & 0 & 0 \\
\hline $\mathbf{6}$ & 0 & 0 & 0 & 0 & 0 & 0 \\
\hline $\mathbf{4}$ & 83 & 36 & 11 & 1 & 0 & 0 \\
\hline $\mathbf{2}$ & 110 & 59 & 11 & 1 & 0 & 0 \\
\hline Totals: & $\mathbf{1 9 3}$ & $\mathbf{9 5}$ & $\mathbf{2 2}$ & $\mathbf{2}$ & $\mathbf{0}$ & $\mathbf{0}$ \\
\hline
\end{tabular}

Hard Bedrock Calibration Site 2 Slope Profile created in CRSP-2D

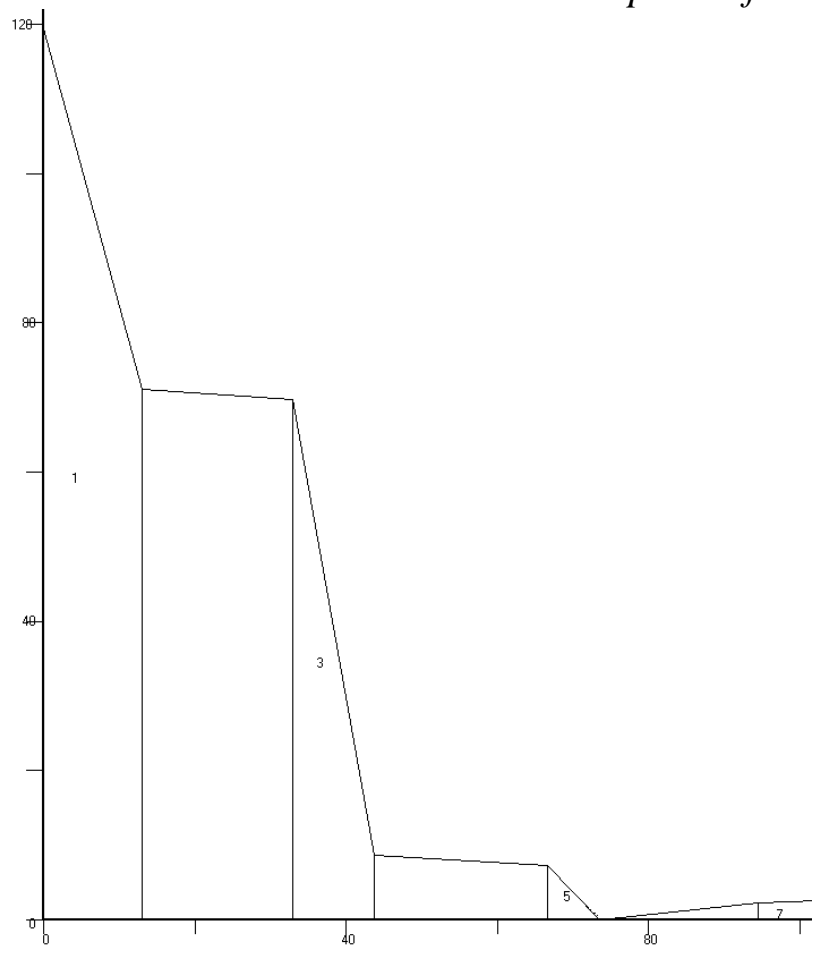


Trial-and-Error CRSP-2D Calibration for Hard Bedrock Calibration Site 2

\begin{tabular}{|c|c|c|c|c|c|c|c|}
\hline \multirow{2}{*}{$\begin{array}{c}\text { Calibration } \\
\text { Run \# }\end{array}$} & \multicolumn{2}{|c|}{$\begin{array}{c}\text { Soft Bedrock } \\
\text { Parameters }\end{array}$} & $\begin{array}{c}\text { Rockfall } \\
\text { Diameter }\end{array}$ & \multirow{2}{*}{$\begin{array}{c}\text { Rockfall } \\
\text { Shape }\end{array}$} & \multicolumn{3}{|c|}{ Rock Accumulation Tally } \\
\cline { 6 - 8 } & $\mathbf{R}_{\mathbf{n}}$ & $\mathbf{R}_{\mathbf{t}}$ & & & $\begin{array}{c}\text { Bench } \\
\mathbf{2}\end{array}$ & $\begin{array}{c}\text { Bench } \\
\mathbf{1}\end{array}$ & Ditch/Road \\
\cline { 6 - 8 } Field & - & - & $<1.0$ & - & 110 & 83 & 0 \\
\hline $\mathbf{1}$ & 0.31 & 0.90 & 0.90 & cylindrical & 125 & 68 & 0 \\
\hline $\mathbf{2}$ & 0.31 & 0.90 & 0.90 & discoidal & 115 & 70 & 8 \\
\hline $\mathbf{3}$ & 0.30 & 0.91 & 0.90 & cylindrical & 117 & 56 & 20 \\
\hline $\mathbf{4}$ & 0.30 & 0.91 & 0.90 & discoidal & 116 & 51 & 25 \\
\hline Field & - & - & $1.0-1.9$ & - & 59 & 36 & 0 \\
\hline $\mathbf{5}$ & 0.31 & 0.90 & 1.30 & cylindrical & 67 & 28 & 0 \\
\hline $\mathbf{6}$ & 0.30 & 0.91 & 1.30 & cylindrical & 61 & 29 & 5 \\
\hline
\end{tabular}




\section{Appendix V: CRSP-2D Simulation Screenshots for Case Studies}

The following figures are screenshots taken from CRSP-2D simulation trials showing the release zones that allowed more than $10 \%$ falling rocks to reach the roadway.

As-Built Case Study Slope Section of US Route 48 - Release Zone: Top of Backslope 2

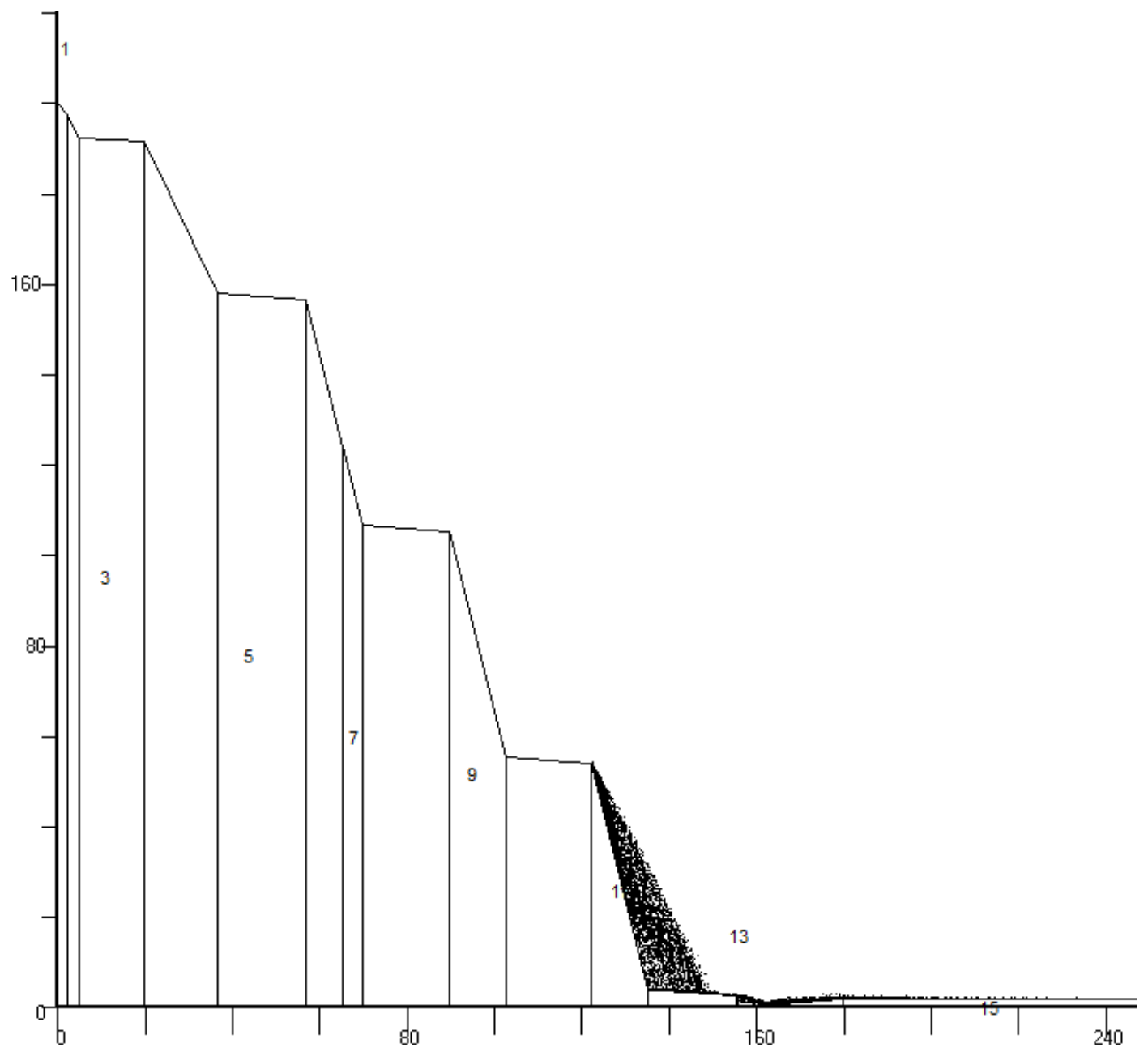


Bench Removal Trial 4 for Case Study Slope Section of US Route 48 - Release Zone: Top of Backslope 1

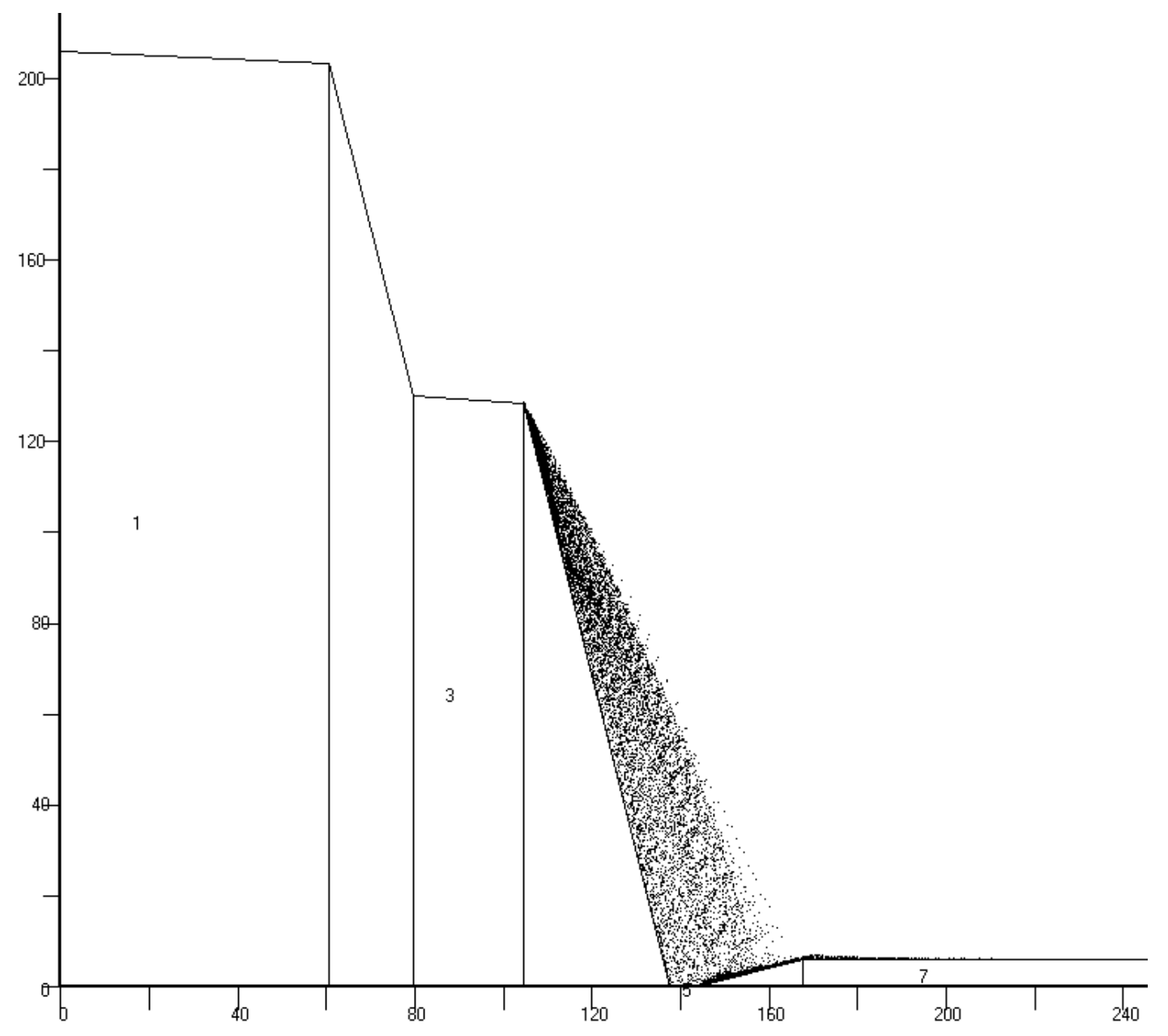


Bench Removal Trial 3 for Case Study Slope Section of US Route 121 - Release Zone: Top of Backslope 1

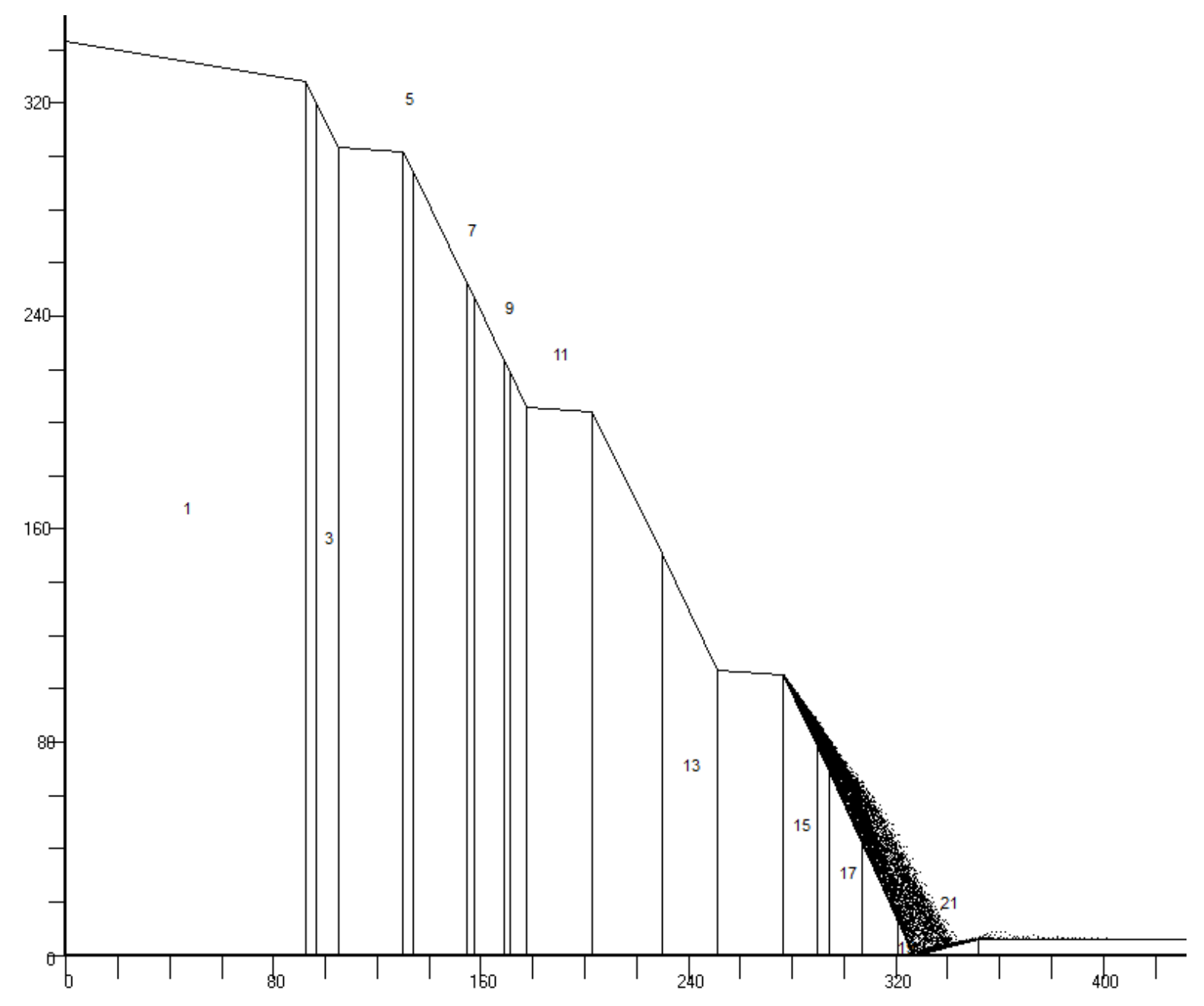


Bench Removal Trial 3 for Case Study Slope Section of US Route 121 - Release Zone: Top of Backlope 2

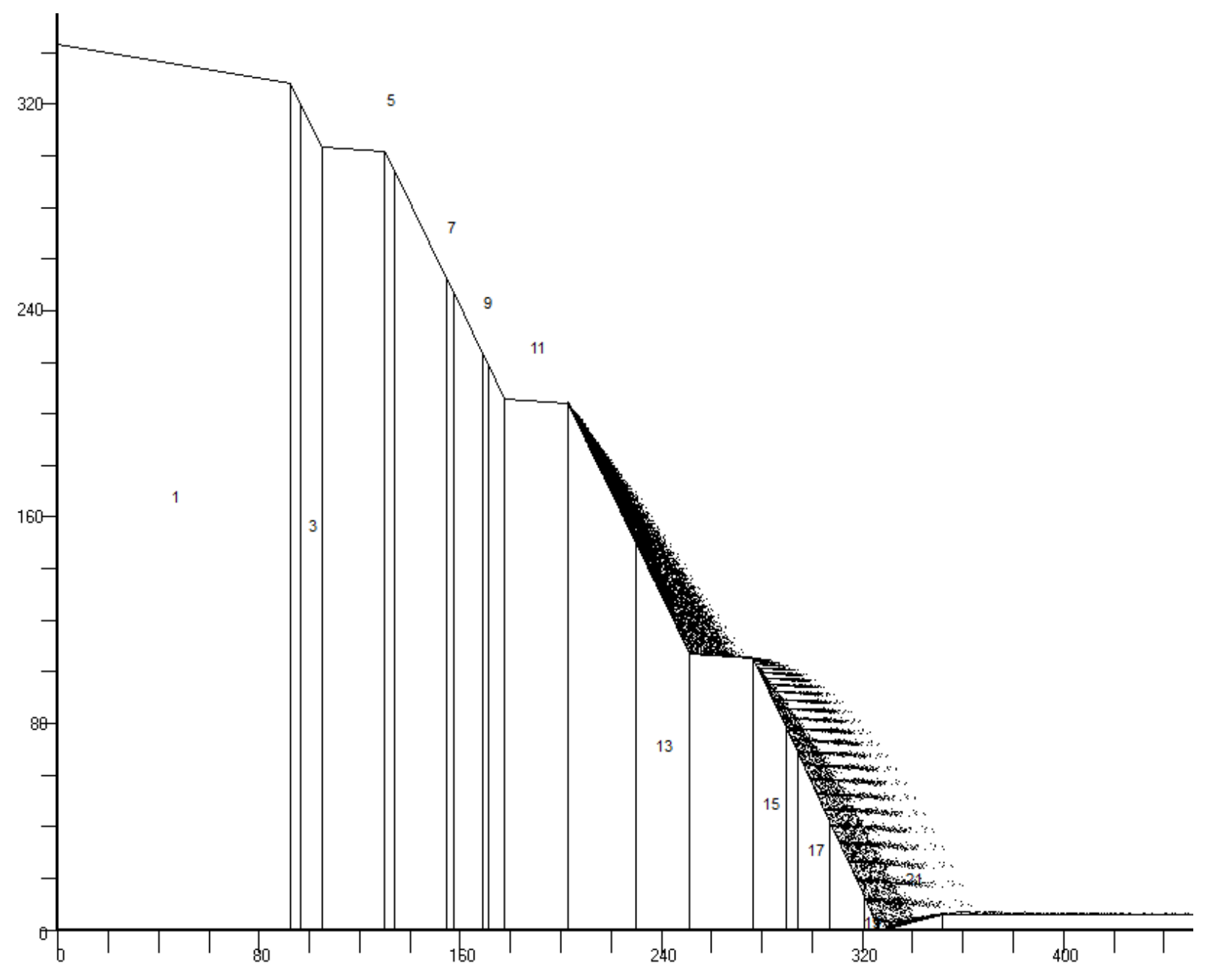


Bench Removal Trial 3 for Case Study Slope Section of US Route 121 - Release Zone: Top of Backlope 3

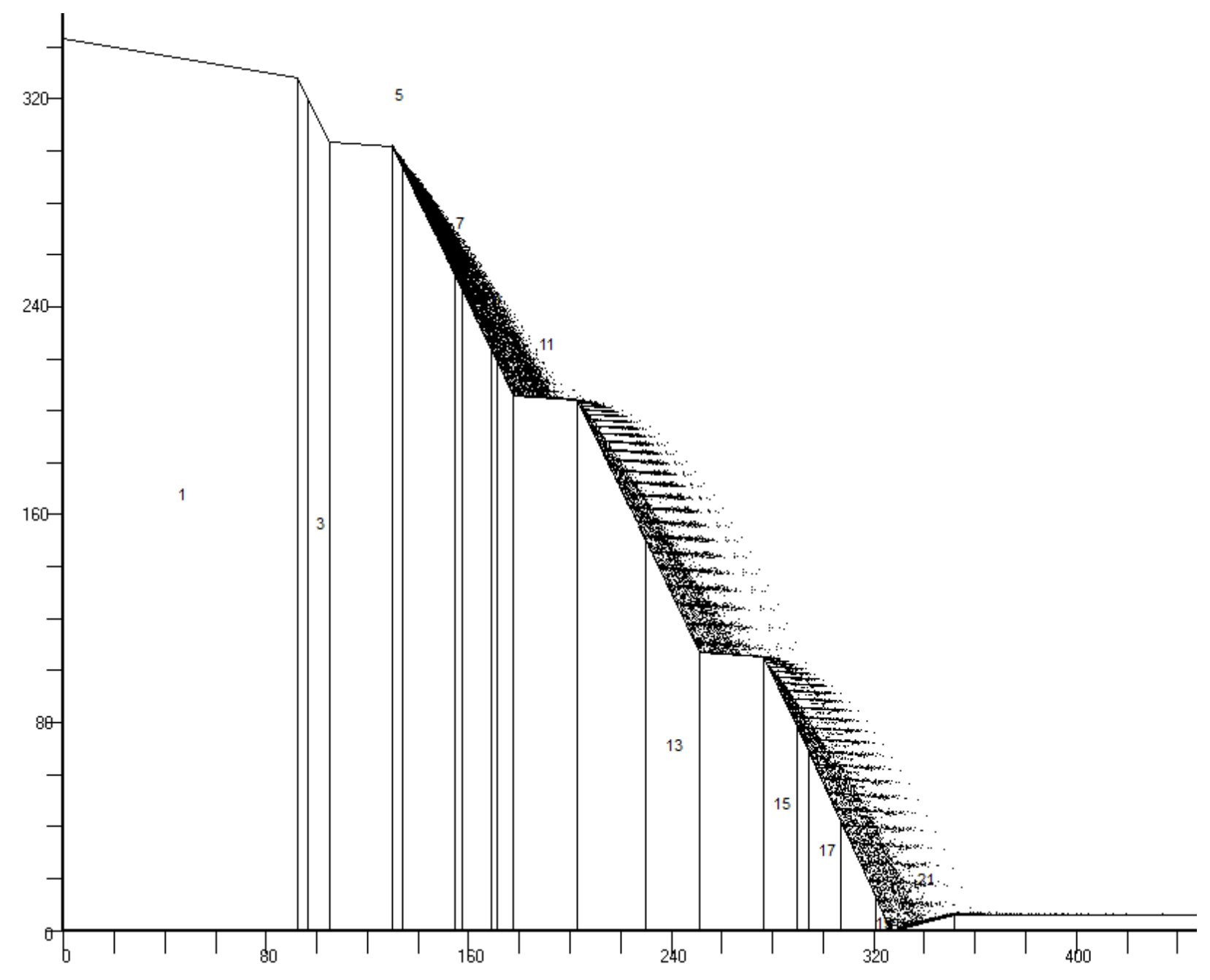


Bench Removal Trial 4 for Case Study Slope Section of US Route 121 - Release Zone: Top of Backslope 1

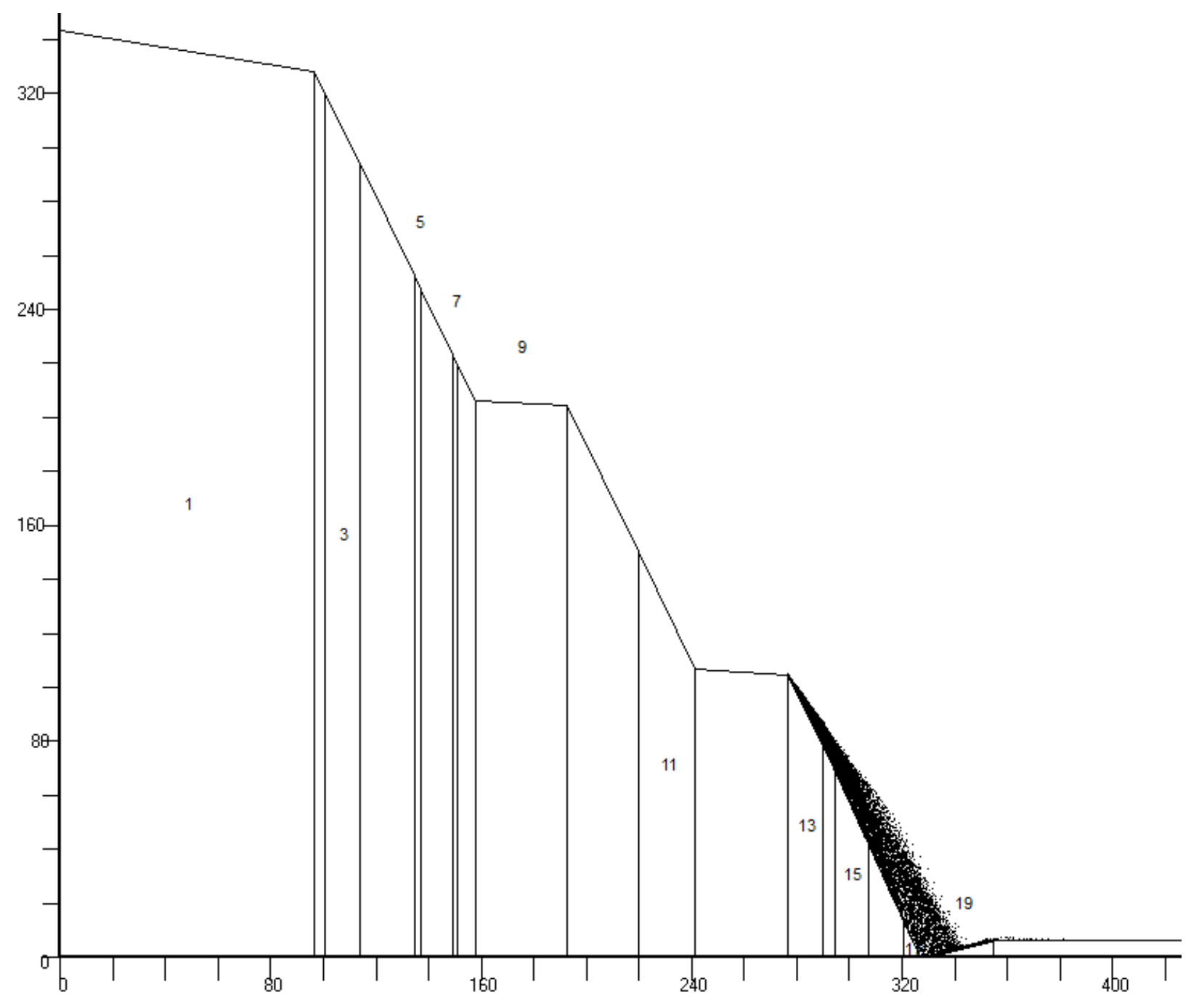




\section{Appendix VI: Rock Slope Design Guide Using CRSP-2D}

The following is a step-by-step procedure for designing highway rock cut slopes with the aid of WVDOT's Design Directive 403 (WV DD-403) and the rockfall simulation program Colorado Rockfall Simulation Program, Version 4.0 (CRSP-2D). This program is available for purchase and download through Colorado Geological Survey at http://geosurvey.state.co.us/.

Design of a Highway Rock Cut Slope in West Virginia:

1. After location of cut and the depth needed to reach roadway grade have been determined, boreholes should be drilled in a manner that creates a comprehensive borehole log of the material layering present in the slope section.

2. Use WV DD-403 to determine the Bedrock Type classification that most closely resembles the borehole log information. The descriptions for each Bedrock Type can be found in the follow table (WVDOH, 2006).

\begin{tabular}{|c|c|}
\hline $\begin{array}{l}\text { Bedrock Type } \\
\text { Classification }\end{array}$ & Description \\
\hline Type 1 & $\begin{array}{l}\text { Hard and Medium-Hard Limestone and Sandstone and Hard Shale } \\
\text { Compressive Strength: } 8000 \text { and above psi. } \\
\text { This bedrock occurs in massive and laminated formations varying in the } \\
\text { degree of dip. In some instances, soft seams of other types of material, such as } \\
\text { coal or shale, may occur. Some types of shale are harder and more resistant to } \\
\text { weathering than medium-hard sandstone. These shales are basically located in } \\
\text { the eastern portion of the State and are in Ordovician, Silurian and Devonian } \\
\text { time periods. The Slake Durability Index of these shales should be above } 95 \\
\text { percent. }\end{array}$ \\
\hline Type 2 & $\begin{array}{l}\text { Soft Limestones and Sandstones, Medium-Hard Shale and Siltstone or } \\
\text { Interbedded Combinations. Compressive Strength: } 4000-8000 \text { psi. } \\
\text { This classification encompasses a large percentage of the material } \\
\text { encountered in West Virginia. In many areas of the State, coal and soft shale } \\
\text { seams are prevalent in these formations. The Slake Durability Index of the } \\
\text { shale in this type would be between } 51 \text { and } 94 \text { percent. }\end{array}$ \\
\hline Type 3 & $\begin{array}{l}\text { Soft Shale Interbedded with Siltstone, Sandstone or Limestone. Compressive } \\
\text { Strength: } 1000-4000 \text { psi. } \\
\text { The shale beds in this bedrock are not massive and the interbedded, harder } \\
\text { bedrock may vary significantly in thickness. Without the interbedded seams } \\
\text { of siltstone, sandstone or limestone, this would be a Type } 4 \text { bedrock. }\end{array}$ \\
\hline Type 4 & $\begin{array}{l}\text { Soft and Very Soft Shale. Compressive Strength: } 1000 \text { psi. } \\
\text { These shales, especially the very soft ones, are considered indurated clays by } \\
\text { some when fissility is lacking. When soaked in water, they usually } \\
\text { disintegrate into particles quite rapidly. The Slake Durability Index for these } \\
\text { shales would be between } 0 \text { and } 50 \text { percent. The beds of this rock are usually } \\
\text { massive and do not contain interbedded seams of siltstone or sandstone. } \\
\text { However, there may be seams or harder shales. }\end{array}$ \\
\hline
\end{tabular}


3. Using the table below, which is modified version of a table found in WV DD-403 entitled "Table for Design of Cut Sections through Bedrock and Overburden," select the steepest backslope ratio recommended for that Bedrock Type. Additionally, select the minimum bench width that corresponds to the selected backslope ratio. Note that if the slope was classified as Type 4 Bedrock, additional observations must be made to determine if the slope should be designed and constructed as rock or as soil. For this reason, Type 4 Bedrock will no longer be discussed in this procedure.

\begin{tabular}{|c|c|c|}
\hline Bedrock Type & $\begin{array}{c}\text { Potential } \\
\text { Backslope Ratios }\end{array}$ & $\begin{array}{c}\text { Minimum Bench } \\
\text { Width (ft.) }\end{array}$ \\
\hline \multirow{2}{*}{ Type 1 } & $1 / 6 \mathrm{H}: 1 \mathrm{~V}$ & 25 \\
\cline { 2 - 3 } & $1 / 4 \mathrm{H}: 1 \mathrm{~V}$ & 25 \\
\cline { 2 - 3 } & $1 / 2 \mathrm{H}: 1 \mathrm{~V}$ & 30 \\
\hline \multirow{2}{*}{ Type 2 } & $1 / 4 \mathrm{H}: 1 \mathrm{~V}$ & 25 \\
\cline { 2 - 3 } & $1 / 2 \mathrm{H}: 1 \mathrm{~V}$ & 30 \\
\cline { 2 - 3 } & $3 / 4 \mathrm{H}: 1 \mathrm{~V}$ & 30 \\
\hline \multirow{2}{*}{ Type 3 } & $1 / 2 \mathrm{H}: 1 \mathrm{~V}$ & 30 \\
\cline { 2 - 3 } & $3 / 4 \mathrm{H}: 1 \mathrm{~V}$ & 30 \\
\cline { 2 - 3 } & $1 \mathrm{H}: 1 \mathrm{~V}$ & 35 \\
\hline \multirow{2}{*}{ Type 4 } & $1 \mathrm{H}: 1 \mathrm{~V}$ & \multirow{2}{*}{ N/A } \\
\cline { 2 - 3 } & $1 \frac{1}{2} \mathrm{H}: 1 \mathrm{~V}$ & \\
\cline { 2 - 3 } & $2 \mathrm{H}: 1 \mathrm{~V}$ & \multicolumn{2}{|c|}{30} \\
\hline
\end{tabular}

4. Place benches on slope only if necessary, at first. Using borehole log information, select bench location(s), if any, using the following guidelines.

a. Place a bench if backslope heights will be over $150 \mathrm{ft}$., as this creates construction and maintenance issues.

b. Place a bench at the top of large friable stratum located below more competent stratum. These are the areas that are most prone to undercutting and should be benched.

c. At Engineer's discretion, place a bench on the slope if higher strata appear heavily fractured and prone to failure. This will allow for on-slope rockfall retention prior to toe-of-slope catchment.

Ensure that all benches are accessible for easy maintenance.

5. Design an RCAD-style ditch to be implemented at the toe of the slope section. Begin with the minimum $25 \mathrm{ft}$. wide, $6 \mathrm{ft}$. deep ditch design; this includes a $1 \mathrm{ft}$. flat bottom and a $24 \mathrm{ft}$., $4 \mathrm{H}: 1 \mathrm{~V}$ exiting frontslope.

6. Develop complete two-dimensional slope geometry for entire slope section. Input geometric data, borehole log data, and calibrated CRSP-2D coefficient values for the slope section.

7. Perform rockfall simulations on the slope section. Test all possible release zones on the slope section to determine the worst case for rockfall reaching roadway. Also, test a range 
of possible rockfall sizes, from $0.5 \mathrm{ft}$. in diameter up to $5 \mathrm{ft}$, , to again determine the worst case for rockfall reaching roadway.

8. If any release zone allows for greater than $10 \%$ of falling rocks to exit the $4 \mathrm{H}: 1 \mathrm{~V}$ slope of the ditch, the slope section must be redesigned (if all zones were below 10\%, skip ahead to Step 10). Observe the results in CRSP-2D to determine the best redesign option. Possible slope redesign options include:

a. Increase bench width.

i. Choose this method if simulation depicted a large percentage of rocks are still leaving the slope (> 50\%). Additional Right-of-Way must also be obtainable.

b. Add additional bench to slope section.

i. Choose this method if simulation depicted majority of rocks having excessively high velocity and energy when contact with bench is made, and rocks are using bench as launching pad to jump over RCAD ditch. Place new bench above original bench. Additional Right-of-Way must also be obtainable.

c. Increase RCAD ditch depth and/or width.

i. Choose this method if simulation depicted that more than $20 \%$ of rocks that reached the RCAD ditch also exited the ditch and reached the roadway. Increase the size of the ditch depending on the average velocity and energy of rocks exiting the ditch.

d. Implement additional catchment devices.

i. Choose this method if additional Right-of-Way is not obtainable. Catchment devices could include barriers, fencing, netting, etc.

9. If slope redesign options a. - c. were selected, return to Step 6. If slope redesign option d. was selected, proceed to Step 10.

10. One minimum required rockfall retention has been reached, test slope for structural stability. If any portion of slope section produces a stability Factor of Safety $<1.25$, remediation efforts must be made. Relationships between slope design and stability are outside the range of this design guide, and thus suggestions cannot be made. Backslope angle may be reduced, but must stay within the ranges displayed in the Table above. After redesigning the slope geometry to obtain a Factor of Safety above 1.25, return to Step 6.

The flowchart on the following page is supplemental to this design guide. 


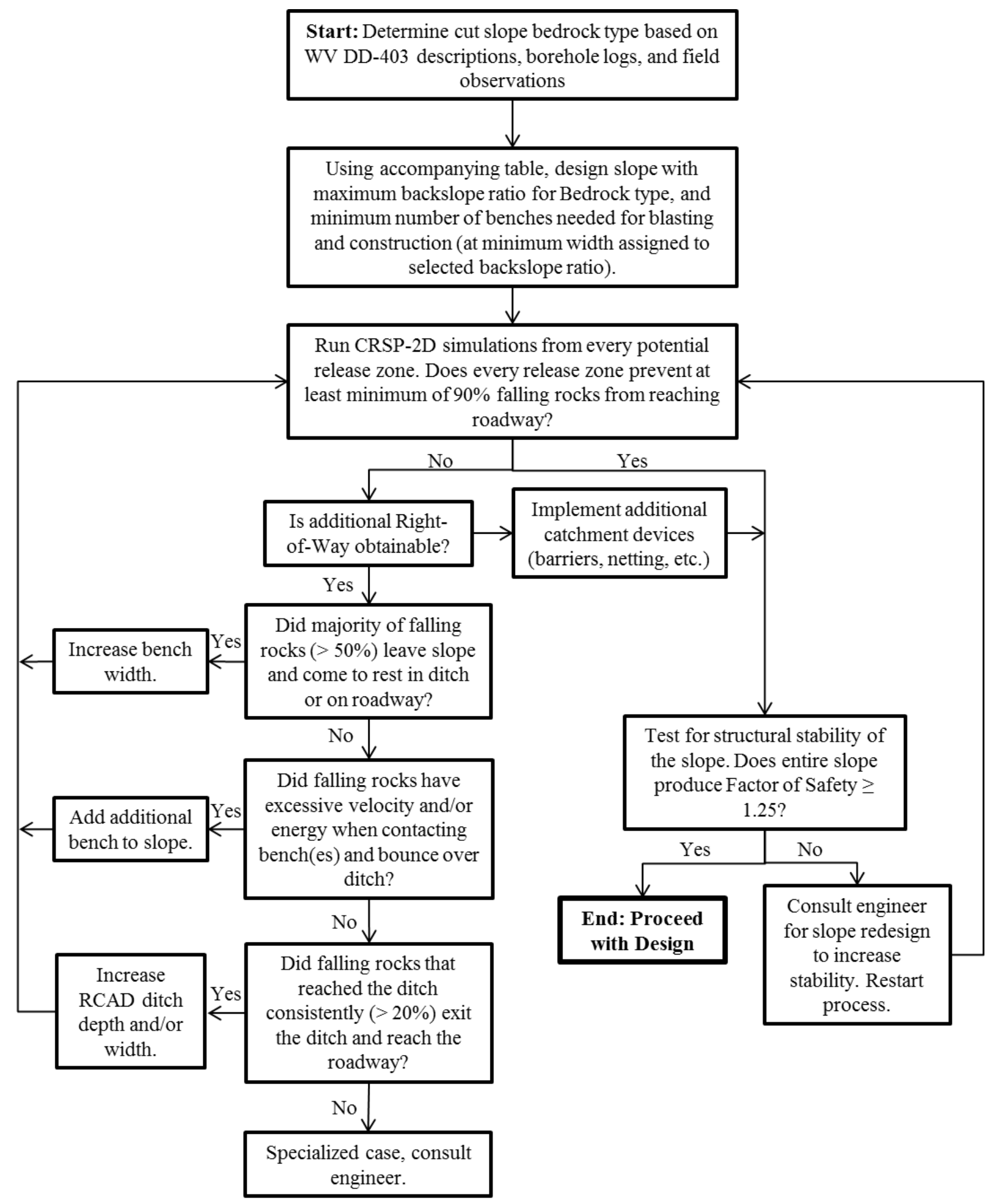

